HELOISA LEONOR BUIKA

\title{
O FORMALISMO NO JUÍZO DE ADMISSIBILIDADE DOS RECURSOS
}

\author{
Dissertação de Mestrado \\ Orientador: Professor Doutor José Carlos Baptista Puoli
}

UNIVERSIDADE DE SÃO PAULO

FACULDADE DE DIREITO

São Paulo - SP

2014 


\title{
O FORMALISMO NO JUÍZO DE
}

\section{ADMISSIBILIDADE DOS RECURSOS}

\author{
Dissertação apresentada à Banca Examinadora do \\ Programa de Pós-Graduação em Direito, da Faculdade de \\ Direito da Universidade de São Paulo, como exigência \\ parcial para obtenção do título de Mestre em Direito, na \\ área de concentração Direito Processual Civil, sob a \\ orientação do Professor Doutor José Carlos Baptista Puoli.
}

UNIVERSIDADE DE SÃO PAULO

FACULDADE DE DIREITO

São Paulo - SP 
Faculdade de Direito da Universidade de São Paulo Serviço de Biblioteca e Documentação

Buika, Heloisa Leonor
O formalismo no juízo de admissibilidade dos

recursos / Heloisa Leonor Buika; orientador Dr. José Carlos Baptista Puoli -- São Paulo, 2014.

$216 \mathrm{p}$.

Dissertação (Mestrado - Programa de Pós-Graduação em Direito Processual) - Faculdade de Direito, Universidade de São Paulo, 2014.

1. Formalismo--Aspectos legais-- Brasil. 2. Recurso especial. 3. Recurso extraordinário. 4. Juízo de admissibilidade. 5. Jurisprudência defensiva. I. Puoli, Dr. José Carlos Baptista, orient. II. Título. 
Ao meu marido Welington, companheiro de todas as horas, e à minha filha Samantha, amiga de toda a vida ...

Com o meu amor, carinho e gratidão pela compreensão, presença e incansável apoio ao longo do período de elaboração desta dissertação. 


\section{AGRADECIMENTOS}

Ao Professor Dr. José Carlos Baptista Puoli, pela atenção e apoio durante $\mathrm{o}$ processo de definição e orientação no desenvolvimento desta dissertação.

À minha amiga Dra. Maria de Fátima Cabral Barroso de Oliveira, pelo apoio e incentivo, desde a decisão de enfrentar o processo seletivo de ingresso no programa de posgraduação da USP.

Aos professores da posgraduação da Faculdade de Direito da Universidade de São Paulo: Dr. Antonio Carlos Marcato, Dr. Cândido Rangel Dinamarco, Dr. Carlos Alberto Carmona, Dr. José Roberto dos Santos Bedaque, Dr. José Rogério Cruz e Tucci, Dr. Marcelo José Magalhães Bonicio e Dr. Ricardo de Barros Leonel, pelas aulas ministradas que muito contribuíram para o amadurecimento deste trabalho.

Aos monitores da posgraduação da Faculdade de Direito da Universidade de São Paulo: Dr. Bruno Vasconcelos Carrilho Lopes, Dr. Fábio Guidi Tabosa Pessoa, Dr. Fernando Fontoura da Silva Cais, Dra. Helena Najjar Abdo e Dr. Marcos André Franco Montoro, pelo acompanhamento dos seminários, indicação de obras e esclarecimentos de dúvidas. 


\section{RESUMO}

Heloisa Leonor Buika (Buika, H. L.) - O formalismo no juízo de admissibilidade dos recursos - Dezembro-2014 - 216 folhas - Mestrado - Faculdade de Direito - Universidade de São Paulo - São Paulo - 2014

Esta dissertação analisa o formalismo no exame de admissibilidade dos recursos, em especial nos Tribunais Superiores. Um dos objetivos desta dissertação foi investigar se o exagero de exigência das formalidades aplicado no momento da admissibilidade impede o conhecimento do mérito dos recursos. São muitos os casos de não conhecimento dos recursos, em razão de vícios que poderiam ser regularizados. Desse modo, são analisados os princípios aplicáveis no âmbito recursal, bem como os aspectos positivos e negativos do formalismo, das técnicas processuais e da efetividade do processo. Efetua-se análise da diferenciação do juízo de admissibilidade e do juízo de mérito, com ênfase nos requisitos intrínsecos e extrínsecos de admissibilidade dos recursos. Discorre-se sobre o aumento dos poderes do relator e a crise enfrentada pelos Tribunais Superiores. Constatou-se que o formalismo excessivo com que os recursos são analisados em sua admissibilidade muitas vezes desvia o objetivo principal da propositura da ação para a discussão de problemas relativos à técnica processual, o que gera uma "jurisprudência defensiva”, que impede a análise do mérito dos recursos. A conclusão principal é a de que deve haver flexibilização dos requisitos de admissibilidade, com a eliminação da "jurisprudência defensiva", de maneira que os Tribunais Superiores possam, com maior frequência, dizer o direito material que deve prevalecer, com a análise do mérito da causa. E isso para que o processo, mesmo em fase recursal, possa atender plenamente o escopo jurídico, acarretando a respectiva pacificação social.

Palavras-chave: formalismo, recursos, juízo de admissibilidade, jurisprudência defensiva. 


\begin{abstract}
Heloisa Leonor Buika (Buika, H. L.) - The formal aspects regarding permission to appeal especially to the Higher Courts - December-2014 - 216 pages - Master - Faculty of Law - University of São Paulo - São Paulo - 2014

This dissertation analyses the formal aspects regarding permission to appeal especially to the Higher Courts. One of the main targets was to investigate whether exaggerated formalities, i.e., those imposed conditions on permission to appeal prevent hearing and considerations regarding the appeals' merit. Several appeals are being refused because of certain irregularities that could be easily solved. Therefore, general rules about appeals are analyzed as well as legal formalism, civil procedure and the rules of adjudication's positive and negatives aspects. Furthermore, differences between permission to appeal, hearing and merit are analyzed focusing in the intrinsic and extrinsic requirements of the permission to appeal as well as the increasing power and the crisis facing Courts of Appeals. It was verified that an excessive formalism in which appeals are analyzed regarding their admissibility divert the main objective of the appeal towards a discussion of problems related to the procedural “techniques” creating a kind of “defensive precedents” impeding the appeals merits' analysis. The main conclusion points to the necessity of a flexibilization of the conditions imposed on the permission to appeal eliminating the "defensive precedents" in a way that the Higher Courts with the analysis of the merit may stipulate what kind of rule of law should prevail in order that the proceedings in the courts totally answer the rules of law fulfilling the judicial expectation of social pacification.
\end{abstract}

Key words: formalism, appeals, permission to appeal, 'defensive precedents’. 


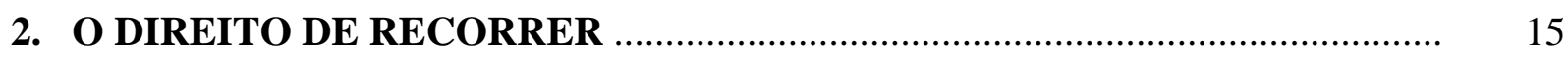

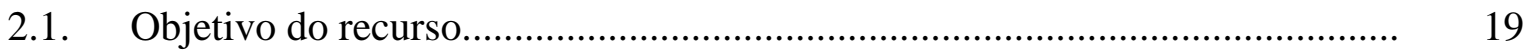

2.2. $\quad$ Duplo grau de jurisdição.................................................................................... 21

2.3. Duplo grau e devido processo legal............................................................... 27

2.4. Argumentos favoráveis do duplo grau de jurisdição....................................... 28

2.5. Argumentos contrários do duplo grau de jurisdição........................................ 29

2.6. Da análise dos argumentos favoráveis e contrários do duplo grau de jurisdição e do formalismo no juízo de admissibilidade dos recursos.

3. PRINCÍPIOS PROCESSUAIS RELACIONADOS AO DIREITO DE

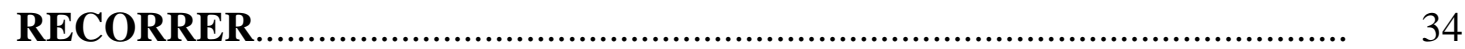

3.1. Princípio da taxatividade recursal.............................................................. 35

3.2. Princípio da colegialidade e das decisões monocráticas proferidas nos tribunais 36

3.3. Princípio da unicidade (ou singularidade, ou unicorribilidade)........................ 38

3.4. Princípio da proibição da reformatio in pejus..................................................... 41

3.5. Princípio da complementaridade........................................................................ 43

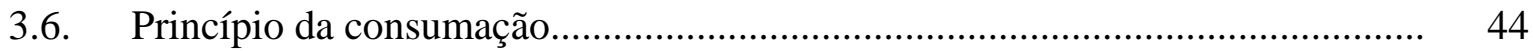

3.7. Princípio da voluntariedade......................................................................... 45

3.8. Princípio da dialeticidade...................................................................... 46

3.9. Princípio da irrecorribilidade em separado das interlocutórias.......................... 47

3.10. Princípio da fungibilidade recursal................................................................. 47

3.10.1. $\quad$ Existência de dúvida objetiva.......................................................... 51

3.10.2. Inexistência de erro grosseiro............................................................. 52

3.10.3. Respeito ao prazo recursal?......................................................... 53

\section{JUÍZO DE ADMISSIBILIDADE E JUÍZO DE MÉRITO DOS

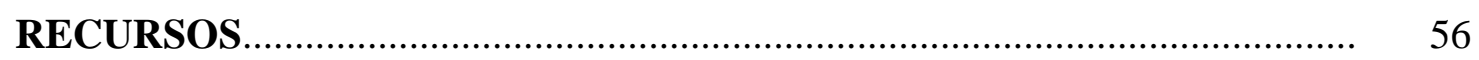

4.1. Diferenciação entre juízo de admissibilidade e juízo de mérito......................... 56

4.2. Da competência para decidir a respeito da admissibilidade dos recursos........... 62 
4.3. Efeitos do juízo de admissibilidade................................................................. 64

4.4. Requisitos de admissibilidade dos recursos em geral ...................................... 65

4.4.1. Requisitos intrínsecos .................................................................... 68

4.4.1.1. Cabimento e adequação.................................................................... 68

4.4.1.2. Legitimidade para recorrer..................................................................... 72

4.4.1.2.1. Legitimidade de quem é parte...................................................... 73

4.4.1.2.2. $\quad$ Legitimidade de terceiro.............................................................. 74

4.4.1.2.3. Legitimidade do Ministério Público............................................ 75

4.4.1.3. Interesse em recorrer ............................................................................. $\quad 75$

4.4.1.4. Inexistência de fato extintivo do direito de recorrer.............................. 78

4.4.2. Requisitos extrínsecos................................................................... 80

4.4.2.1. Tempestividade ................................................................................ 80

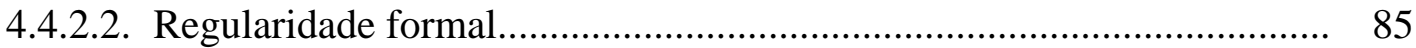

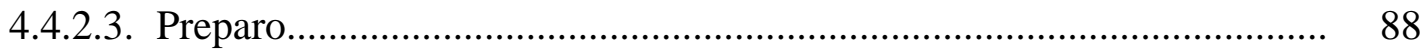

4.4.2.3.1. Preparo e não ocorrência do fato gerador.................................... 92

4.4.2.3.2. Preparo e assistência judiciária.................................................... 93

4.5. Aspectos da admissibilidade dos recursos ordinários...................................... 98

4.6. Aspectos da admissibilidade dos recursos excepcionais..................................... 103

5. FORMA E FORMALISMO NO ÂMBITO RECURSAL ................................... 111

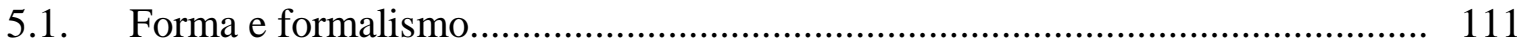

5.2. Aspecto positivo do formalismo, técnicas processuais e efetividade do processo.......................................................................................... 116

5.3. Aspecto negativo do formalismo........................................................... 119

5.3.1. Efetividade, tempo e duração do processo....................................... 121

5.4. $\quad$ A instrumentalidade de formas e o acesso à justiça.......................................... 124

5.5. O equilíbrio entre o formalismo e o acesso à justiça......................................... 127

6. A CRISE DOS TRIBUNAIS SUPERIORES.................................................. 130

6.1. Tribunais superiores - uma avalanche de processos e poucos ministros para

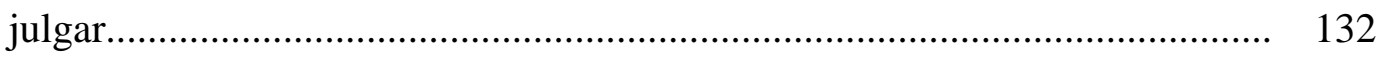

6.2. Juízo de admissibilidade mais rigoroso como técnica para restringir o número de processos nas instâncias superiores 


\section{O EXCESSO DE FORMALISMO NO JUÍZO DE ADMISSIBILIDADE DOS RECURSOS NOS TRIBUNAIS SUPERIORES............................................ 141}

7.1. Jurisprudência defensiva dos tribunais superiores......................................... 142

7.2. Alguns casos de excesso de formalismo no juízo de admissibilidade................ 143

7.2.1. Quanto ao requisito da tempestividade recursal............................. 143

7.2.1.1. Intempestividade por prematuridade........................................ 144

7.2.1.2. $\quad$ Necessidade de ratificação do recurso........................................ 146

7.2.1.3. Comprovação da tempestividade em razão de causas locais...... 148

7.2.1.4. Intempestividade quanto a data do protocolo do recurso.......... 148

7.2.2. Quanto ao requisito da regularidade formal.................................. 151

7.2.2.1. Exigência de certidão de intimação da decisão agravada.......... 151

7.2.2.2. Comprovação da representação processual .............................. 152

7.2.2.3. Quanto ao não conhecimento do recurso em razão do esquecimento do advogado em assinar as razões do recurso ou assinar digitalmente... 154

7.2.2.4. Razões apresentadas após a interposição do recurso................... 155

7.2.3. Quanto ao requisito preparo....................................................... 156

7.2.3.1. Preenchimento das guias de preparo e comprovação posterior... 156

7.2.3.2. Quanto a não aceitação do pagamento das custas via internet.... 158

7.2.3.3. Quanto ao preenchimento da GRU.......................................... 160

8. O AUMENTO DOS PODERES DO RELATOR ….................................... 165

8.1. Competência funcional do relator....................................................... 175

8.2. Natureza da decisão do relator.......................................................... 178

8.3. Poder/dever do relator.................................................................... 179

8.4. $\quad$ Motivação da decisão unipessoal.......................................................... 180

9. O NOVO CPC E A BUSCA DO EQUILÍBRIO........................................... 182

9.1. Tentativa de equilíbrio ....................................................................... 190

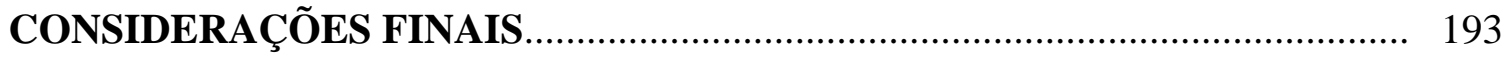

REFERÊNCIAS BIBLIOGRÁFICAS....................................................... 198 


\section{INTRODUÇÃO}

O Poder Judiciário brasileiro está enfrentando uma intensa conflitualidade, com uma sobrecarga de processos, o que gera uma crise de desempenho e perda de credibilidade. Essa situação decorre, em grande parte, das transformações pelas quais a sociedade brasileira vem passando, as quais são provenientes de vários fatores, dentre os quais encontra-se a economia de massa. ${ }^{1}$

Na época da edição do Código de Processo Civil de 1973, o sistema recursal foi considerado um dos aspectos mais positivos do texto então aprovado, pela simplificação que representou perante o sistema anterior. Cabe lembrar que o Código de 1939 previa três recursos diferentes contra decisões interlocutórias (agravo de instrumento, agravo no auto do processo e carta testemunhável) e dois recursos distintos contra sentenças (apelação e agravo de petição).

Após quatro décadas, o Código de Processo Civil de 1973, ainda vigente, com sucessivas reformas feitas a partir de 1995, tem se mostrado ineficiente, se comparado com os de outros países e se avaliado o seu resultado do ponto de vista da qualidade e da credibilidade das decisões proferidas em processos por ele regulados. ${ }^{2}$

Segundo Leonardo Greco, atualmente, o nosso sistema recursal é apontado por muitos como o responsável pela crise da Justiça brasileira, conforme se manifestou a Comissão de Constituição e Justiça do Senado Federal, ao analisar a proposta de Emenda à Constituição que originou a Emenda Constitucional n. ${ }^{\circ}$ 45/2004. Salienta que é um sistema formalista, uma vez que cria obstáculos à apreciação dos recursos e propicia a produção de julgados que, em lugar de aumentarem a probabilidade de acerto e de justiça das decisões que pretendem rever, transformam os julgamentos em verdadeira “caixa de surpresas”, criando situações totalmente imprevisíveis para as partes e que, a pretexto do volume excessivo de processos, dão pouca atenção às questões fáticas e jurídicas suscitadas e aos argumentos dos advogados. De outro lado, também cabe mencionar que, salvo melhor juízo, a tendência de, no julgamento dos recursos, prestigiar e "replicar” as decisões de

\footnotetext{
1 WATANABE, Kazuo. Política pública do Poder Judiciário Nacional para tratamento adequado dos conflitos de interesse. Revista de Processo, São Paulo, ano 36, v. 195, p. 382, maio 2011.

${ }^{2}$ GRECO, Leonardo. Princípios de uma teoria geral dos recursos. Revista Eletrônica de Direito Processual, v. 5. Disponível em: <http://www.arcos.org.br/periodicos/revista-eletronica-de-direito-processual/volumev/principios-de-uma-teoria-geral-dos-recursos>. Acesso em: 14 mar. 2013.
} 
casos similares anteriormente julgados também acaba por fomentar o fenômeno formalista, eis que, em vez de existir efetivo julgamento do mérito, os Tribunais acabam por se preocupar, mais e mais, em encontrar afinidades dos novos casos com outros anteriormente julgados (pelo mesmo Tribunal ou por Tribunais Superiores) para, assim, de forma simplista e absolutamente distante do litígio real, transportar fundamentos destes para aqueles, automatizando os julgamentos. ${ }^{3}$

Essa aparente deformidade do processo judicial, como apontada por Leonardo Greco, é detectada em três pontos de vista diferentes: primeiro, o dos tribunais superiores, cuja preocupação predominante é com a eliminação da quantidade de processos e recursos, mesmo em detrimento da qualidade e justiça das decisões; segundo, o dos governantes, que se habituaram a utilizar a justiça para postergar o cumprimento das obrigações do Estado para com os cidadãos; por último, o dos próprios jurisdicionados que, quando vencidos, se sentem impelidos a esgotar as vias recursais, porque estas se apresentam como facilmente acessíveis e resultam, por vezes, mais vantajosas que o cumprimento espontâneo das suas obrigações. $^{4}$

Um dos elementos da intolerável demora com que a máquina judiciária responde à demanda da tutela que está a cargo do Poder Judiciário é proveniente do sistema recursal, em que se encontra um dos maiores fatores de congestionamento. A ampla recorribilidade de toda e qualquer decisão final ou interlocutória, pela sua desnecessária exacerbação, é, sem dúvida, o grande embaraço com que se depara o processo civil brasileiro. ${ }^{5}$

Em razão do grande aumento do volume de recursos que agravaram os defeitos do sistema, têm sido realizadas sucessivas reformas no sistema recursal com o intuito de tentar minimizar o problema. No entanto, ainda impera a ineficiência, uma vez que não foi possível mitigar a cultura litigiosa, tanto do Estado quanto dos cidadãos, tendo sido eficazes somente na instituição de filtros de acesso às instâncias recursais superiores.

Ao estudo dessas mazelas se propõe este trabalho, que inicialmente tratará sobre o direito de recorrer, uma vez que a necessidade de impugnação das decisões judiciais provém de duas razões: a primeira, consistente na possibilidade de erro existente na

\footnotetext{
${ }^{3}$ Ibidem.

${ }^{4}$ Ibidem.

${ }^{5}$ THEODORO JÚNIOR, Humberto. Inovações da Lei 10.352/01. In: NERY JR., Nelson; WAMBIER, Teresa Arruda Alvim (Coord.). Aspectos polêmicos e atuais dos recursos cíveis. São Paulo: RT, 2002. v. 6, p. 263.
} 
decisão recorrida, e nesse sentido objetiva afastar os vícios que as sentenças possam ter, dado que o prolator da sentença não está imune a erro; e a segunda decorre do inconformismo da parte vencida, proveniente da própria natureza do ser humano, que busca um desfecho favorável para a solução do conflito levado a juízo.

Analisar-se-á, pois, o duplo grau de jurisdição, se ele pode ser mitigado por um tão grande formalismo que, salvo melhor juízo, hoje impera no âmbito da análise dos recursos.

Também serão examinados outros princípios que norteiam o sistema recursal perante o juízo de admissibilidade dos recursos e diante da análise dos problemas inerentes à não admissão dos recursos.

Tal análise será desenvolvida com a preocupação de compreender as razões do excesso de formalismo em sede recursal, principalmente nos tribunais superiores, comparando essa situação com o que preconiza a doutrina no âmbito geral do processo (na qual ocorre vetor inverso, de diminuição do império das formas). Tratar-se-á dos aspectos positivo e negativo ${ }^{6}$ das formas processuais, e, ainda, do risco de que o excesso de formalismo impeça a realização dos escopos do processo, em detrimento do objeto de direito material que originou o litígio, e levou a parte a procurar o Judiciário para a solução do conflito, e, para ilustrar os pontos relevantes a respeito do tema, serão expostos alguns exemplos.

Outro ponto a ser analisado é o da instrumentalidade e das técnicas processuais perante os princípios do devido processo legal e da instrumentalidade das formas, ou seja, até que ponto o desapego às formas não comprometerá a segurança jurídica, principalmente em sede recursal.

Se o escopo do direito processual é proporcionar meios de alcance ao direito material almejado pelo autor, como fica esse direito se o formalismo exacerbado desvirtua a finalidade do que o levou a acessar a justiça? O que é mais importante: a justiça procurada pela parte que almeja a tutela de um direito ou o apego às formas procedimentais?

O que se pretende abordar não são as falhas da legislação, mas sim os obstáculos processuais ilegítimos criados pelos tribunais com o propósito de não admitir recursos, sem a mínima preocupação com o direito que a parte busca no Judiciário.

\footnotetext{
${ }^{6}$ Cândido Rangel Dinamarco nomina essa dicotomia de instrumentalidade negativa e instrumentalidade em seu aspecto positivo (A instrumentalidade do processo. 14. ed. São Paulo: Malheiros, 2009b, p. 316 e 319 ).
} 
Os tribunais estão entupidos de processos e veem-se com frequência julgamentos que supervalorizam determinadas formalidades processuais, que nada contribuem para o desfecho do litígio, em flagrante prejuízo da avaliação do direito material discutido, em desrespeito à garantia de acesso à justiça. ${ }^{7}$

O duplo grau de jurisdição em seu aspecto positivo induz ao raciocínio de que a decisão de segundo grau substitui a de primeiro grau, e, por ter sido proferida por um órgão colegiado, muitas vezes por magistrados com mais experiência e independência, baseou-se em exame mais aprofundado do litígio, e, consequentemente, a decisão é mais justa, constituindo-se, assim, uma decisão de qualidade.

Já em seu aspecto negativo tem-se que o duplo grau induz a uma excessiva duração do processo, o que irá esbarrar no formalismo, também em seus aspectos positivo e negativo.

Em decorrência, questiona-se: para mitigar a questão do excesso de tempo gerado pelo duplo grau, é necessária a extrapolação dos rigores formais dos recursos? Ou seja, o excessivo formalismo no juízo de admissibilidade pode ser utilizado como um remédio para evitar a delonga no processo por conta dos recursos?

Para tanto, pretende-se dar especial atenção ao que tem ocorrido nos últimos anos no âmbito dos Tribunais Superiores, que ora demonstram desapego ao formalismo e muito contribuem na busca por Justiça, ora tratam com extremo rigor requisitos formais aparentemente irrelevantes, em detrimento do objetivo magno do processo que é o de bem aplicar o direito material em conflito. Em vista disso, pretende-se investigar essas situações e tentar verificar em que medida a doutrina pode colaborar para a busca de um denominador comum entre permitir eficiências nos Tribunais, sem penalizar as partes que anseiam por ver decididos seus recursos quanto ao mérito das demandas.

De outro lado, considerando que nossa legislação tem dotado o relator de maiores poderes para, monocraticamente, realizar o juízo de admissibilidade dos recursos, será dedicado um capítulo à análise desses poderes do relator, com ênfase na evolução da ampliação deles, verificando sua natureza e alcance.

\footnotetext{
${ }^{7}$ MILLER, Cristiano Simão. O formalismo processual em sede recursal como obstáculo ao acesso à justiça. Anais do XVIII Congresso Nacional do CONPEDI, realizado em São Paulo - SP em 4 a 7 nov. 2009. Disponível em: <http://www.publicadireito.com.br/conpedi/manaus/arquivos/Anais/sao_paulo/2487.pdf>. Acesso em: 16 ago. 2010.
} 
Também será analisado o tratamento que ao tema do formalismo recursal pode ser dado pelo Novo Código de Processo Civil, e, nesse diapasão, insta realçar que a mais recente versão do projeto de Novo Código de Processo Civil, aprovada em 26.03.2014 pela Câmara dos Deputados, demonstra a preocupação dos legisladores em permitir sejam saneadas as irregularidades do sistema recursal, conforme previsto em seu artigo 1.042 e parágrafos.

Essa versão servirá mesmo como modo de diminuir o formalismo na admissibilidade dos recursos? Mas como explicar tal proposta legislativa no atual contexto em que o vetor da prática parece sinalizar o contrário, em termos cada vez mais haver maior rigor no âmbito da admissibilidade recursal? Enfim, pretende-se verificar, ainda, como será possível adequar tal prática com a proposta que se apresenta no âmbito do projeto de lei.

Ao final, verificar-se-á se é possível estabelecer equilíbrio entre a busca por justiça e o formalismo processual (necessário e que jamais poderá ser abandonado), porém sem transformá-lo no objetivo principal do julgamento do processo, ainda que este esteja em fase recursal, tentando ajustar a técnica processual, com intuito de garantir que haja, no maior número possível de casos, exame do mérito do processo, com alcance de decisões que pacifiquem as situações da vida.

Para os fins do presente estudo, adotaremos o vocábulo formalismo em seu aspecto negativo, ou seja, no sentido de tratar-se de excesso de forma, sendo a aplicação da forma exagerada. Assim, ao mencionarmos a palavra formalismo, estaremos nos referindo à forma aplicada de modo irracional, que deve ser repudiada, uma vez que a regra da instrumentalidade deve cumprir o seu papel de conduzir as partes à solução do litígio, originado no direito material.

\footnotetext{
${ }^{8}$ Câmara dos Deputados - Comissão Especial destinada a proferir parecer ao Projeto de Lei n. ${ }^{\circ}$ 6.025, de 2005, ao Projeto de Lei n. ${ }^{\circ}$ 8.046, de 2010, ambos do Senado Federal, e outros, que tratam do "Código de Processo Civil” (revogam a Lei n. ${ }^{\circ}$ 5.869/1973) - PL 602505. Disponível em: $<$ http://pt.scribd.com/doc/131517889/NOvo-CPC-Substitutivo-Preliminar-Dep-Paulo-Teixeira-20-03-13>. Acesso em: 20 maio 2014. O projeto está para ser votado no Congresso Nacional (dezembro 2014)
} 


\section{O DIREITO DE RECORRER}

Para falarmos sobre o direito de recorrer, faz-se necessária a definição de recurso: é o inconformismo, total ou parcial, de quem não recebeu um pronunciamento favorável, impugnando decisão, não transitada em julgado, com o objetivo de reformá-la ou invalidála. ${ }^{9}$

Segundo Teresa Arruda Alvim Wambier, em nosso sistema, o direito ao recurso se confunde com o direito à obtenção de uma prestação jurisdicional mais qualificada, ou seja, com o direito à obtenção de uma decisão o mais correta possível. ${ }^{10}$

Os recursos são um dos elementos basilares integrantes do chamado "devido processo legal”, previsto no art. 5. ${ }^{\circ}, \mathrm{LX}$, da Constituição Federal. A problemática está no elevado número de meios de impugnação colocados à disposição dos litigantes que consequentemente abarrotam os tribunais e eternizam os processos. ${ }^{11}$

Diverso é o modelo norte-americano, em que o direito ao recurso (rigth of appeal) não se encontra compreendido na garantia do due process of law, previsto na $5 .^{a}$ e $14 .^{a}$ Emendas à Constituição, segundo as quais nem a União nem os Estados poderão privar alguém de sua vida, liberdade ou propriedade sem o devido processo legal. Os litigantes somente terão direito a recorrer quando houver previsão legal infraconstitucional, bem como o conhecimento do recurso dependerá do preenchimento de seus requisitos de admissibilidade, tal como se dá no direito brasileiro. ${ }^{12}$

No direito inglês, também inexiste o direito constitucional ao recurso, o qual decorre de previsão em lei aprovada pelo Parlamento (statute), não sendo inerente ao direito de ação. ${ }^{13}$

\footnotetext{
${ }^{9}$ TEIXEIRA, Sálvio de Figueiredo. O recurso especial e o Superior Tribunal de Justiça. In: Recursos no Superior Tribunal de Justiça. São Paulo: Saraiva, 1991. p. 68.

${ }^{10}$ WAMBIER, Teresa Arruda Alvim. Restrições indevidas ao direito de recorrer. Revista de Processo. São Paulo, n. 130, p. 249, 2005b.

${ }^{11}$ FIGUEIRA JÚNIOR, Joel Dias. A trama recursal no processo civil brasileiro e a crise da jurisdição estatal. Revista de Processo. São Paulo, n. 188, p. 268-269, 2010.

${ }^{12}$ YOSHIKAWA, Eduardo Henrique de Oliveira. Recursos no direito processual civil norte-americano. Revista de Processo. São Paulo, ano 38, v. 221, p. 160-161, 2013; LOBSENZ, James J. A constitution right to an appeal: guarding against unacceptable risks of erroneous conviction. Disponível em: $<$ http://digitalcommons.law.seattleu.edu/cgi/viewcontent.cgi?article=1197\&context=sulr $>$. Acesso em: 15 ago. 2014. "Since the common law failed to recognize an absolute right to appeal, it followed the review by an appellate court was 'not a necessary element of due process of law... There is, of course, no constitution right to an appeal'."

${ }^{13}$ YOSHIKAWA, Eduardo Henrique de Oliveira. Recursos no processo inglês. Revista de Processo. São Paulo, ano 38, v. 220, p. 170-171, 2013. "The right of appeal to the Supreme Court is regulated by statute and
} 
Desde tempos remotos, os diferentes ordenamentos jurídicos têm se preocupado com a correção de possíveis erros contidos nas decisões judiciais. Há sempre duas solicitações, antagônicas entre si, sendo uma a conveniência da rápida solução dos litígios, com intuito de prontamente restabelecer a ordem social, e a outra de garantir, na medida do possível, a conformidade da solução ao direito. Entre essas duas solicitações, os ordenamentos jurídicos procuram uma via mediana que não sacrifique, além do limite razoável, a segurança à justiça e vice-versa. Atender a primeira solicitação, ou seja, tornar as decisões inimpugnáveis, ocorreria o insuportável detrimento da segurança à justiça; por outro lado, multiplicar infinitamente os meios de impugnação produziria efeito diametralmente oposto e igualmente danoso. ${ }^{14}$

É natural que a pessoa fique inconformada com o resultado negativo da demanda. Essa realidade é estampada nos lares, onde se pode ver quando um filho pede um presente à mãe e esta o nega, logo recorre ao pai, e, se ainda houver recusa, o pedido será dirigido aos avós. O que se denota nessa conduta humana já nos primeiros anos de idade? É o inconformismo da psique humana com a decisão que lhe é adversa. O ser humano é dotado de inconformismo, pois é da natureza humana não se conformar com o seu revés, o inconformismo é eterno no homem. Transportando-se essa situação para o campo da decisão judicial, se fosse permitido às partes permanente e livre acesso ao sistema recursal, haveria a propositura de recursos infinitamente, razão pela qual há necessidade de se estabelecer um número certo de recursos que propiciem as pessoas desenvolver um pouco dessa insatisfação e concomitantemente permitir a um só tempo alcançar o reexame da decisão judicial, sem, no entanto, eternizar a entrega dessa decisão, porque justiça que tarda não é justiça. Portanto, entende Sergio Rizzi que a justiça precisa ser rápida, seja por razões de composição do dissídio social, seja por motivos de ordem econômica, devendo o sistema recursal abrigar essas duas realidades e ter poucos recursos e mecanismos para que as partes possam permanecer com o inconformismo retido, de modo a não fazerem uso obrigatório do recurso quando isso não lhes parecer oportuno. ${ }^{15}$

is subject to several statutory restrictions. The Human Rights Act 1998 applies to The Supreme Court in its judicial capacity. But that act does not confer any general right of appeal to The Supreme Court, or any right of appeal over and above any right of appeal which was provided for in Acts passed before the coming into force of the Human Rights Act 1998.” Disponível em: <http://supremecourt.uk/docs/a-guide-to-bringing-acase-to-the-uksc.pdf>. Acesso em: 15 ago. 2014.

${ }^{14}$ BARBOSA MOREIRA, José Carlos. Comentários ao Código de Processo Civil. 15. ed. Rio de Janeiro: Forense, 2010. item 134, v. 5, p. 229.

${ }^{15}$ RIZZI, Sérgio. Recurso adesivo. Revista de Processo. São Paulo, ano VIII, n. 30, p. 252, 1983. 
Nessa linha de raciocínio, Carlos Alberto Carmona ${ }^{16}$ faz uma crítica ao sistema recursal brasileiro, sugerindo uma revisão do sistema de agravos incompatíveis com o princípio da oralidade, bem como a abolição dos embargos infringentes, e entende que um sistema processual coerente deve manter somente recursos que bastem para o funcionamento adequado do processo.

Outro fator que leva a parte inconformada a recorrer é apontado por Vittorio Denti e Michelle Taruffo, os quais discorrem que os problemas conexos com a estrutura burocrática da administração da justiça e o sistema de recrutamento dos magistrados, na Itália, se traduzem na garantia de que as causas em primeiro grau são entregues a magistrados que estão no início de carreira, cuja idade em média está em torno de 30-35 anos, porque progredir na mesma carreira significa passar à função de juiz de 2. ${ }^{a}$ instância e posteriormente a juiz de cassação. Isso se traduz, inevitavelmente, em um menor prestígio do magistrado nos confrontos dos litigantes (também de seus advogados), em razão de um alto grau de opinabilidade de seus provimentos e na dificuldade de impor, no início da causa, a aceitação de um quadro de definição da controvérsia que leva as partes a uma solução conciliativa. Em outros termos, o centro de gravidade das causas não é, como deveria ser, um sistema equilibrado, no juízo de primeiro grau, porque a falta de prestígio de suas decisões leva a um uso excessivo de recursos para a 2. ${ }^{a}$ instância e a Corte de Cassação. $^{17}$

A possibilidade de utilização dos meios de impugnação não deve ser ilimitada, pois a ampla impugnabilidade das decisões prolongando o processo em nome do valor justiça acaba constituindo um desserviço à função apaziguadora que é inerente ao mecanismo. ${ }^{18}$

O Código de Processo Civil prevê várias regras relativas ao abuso do direito de recorrer, sendo uma geral, esculpida no inciso VII do artigo 17 (reputa-se litigante de má-

\footnotetext{
${ }^{16}$ CARMONA, Carlos Alberto. O sistema recursal brasileiro: breve análise crítica. In: NERY JR., Nelson; ARRUDA ALVIM, Eduardo Pellegrini de; WAMBIER, Teresa Arruda Alvim (Coord.). Aspectos polêmicos e atuais dos recursos. São Paulo: RT, 2000. p. 50.

${ }^{17}$ DENTI, Vittório; TARUFFO, Michele. Costo e durata del processo civile in Itália. Rivista di Diritto Civile. Padova, anno XXXII, n. 3, p. 291, 1986.

${ }^{18}$ Nesse sentido, Marcos André Franco Montoro enfatiza o binômio qualidade/velocidade afirmando que: “a supressão total dos meios de impugnação privilegiaria este último, mas sacrificaria enormemente o primeiro. Todavia, a possibilidade ampla (ou ilimitada) de meios de impugnação, que em tese daria uma maior certeza ao acerto da decisão, além de levar a um prolongamento excessivo do tempo do processo, possibilitaria um estado de incerteza contrário às finalidades do processo" (Requisitos de admissibilidade do recurso especial. 2005. Dissertação (Mestrado) - USP, São Paulo, p. 26). No mesmo sentido: ASSIS, Araken de. Condições de admissibilidade dos recursos cíveis. In: NERY JR., Nelson; WAMBIER, Teresa Arruda Alvim (Coord.). Aspectos polêmicos e atuais dos recursos cíveis de acordo com a Lei 9.756/98. São Paulo: RT, 1999. p. 11-51.
} 
fé aquele que interpuser recurso com intuito manifestamente protelatório), e outras regras específicas dizem respeito aos embargos de declaração, cujo parágrafo único do artigo 538 menciona "meramente protelatórios" e ao agravo de instrumento "manifestamente inadmissível ou infundado” (artigo 557, § 2. ${ }^{\circ}$ ).

A lei processual também prevê penalidade para aquele que comete abuso ao direito de recorrer, conforme artigo $18, \S \S 1 .^{\circ}$ e $2 .^{\circ}$.

O direito de recorrer pode ser associado a três finalidades principais: a) melhoria da prestação jurisdicional; b) unificação do direito; e c) controle da atividade judicial.

Há duas classes fundamentais de remédios utilizáveis contra as decisões judiciais: a dos recursos e a das ações autônomas de impugnação. Estas últimas são remédios que se dirigem contra decisões já transitadas em julgado, enquanto os recursos são utilizados para a impugnação de decisões que ainda não têm a sua res iudicata formada e têm o objetivo precípuo de impedi-la. $^{19}$

Outro critério de classificação demonstra que não será recurso quando o remédio produz a instauração de um processo distinto daquele que gerou a decisão impugnada. Dessa forma, não somente as ações autônomas de impugnação, a exemplo da ação rescisória, mas também o mandado de segurança contra ato judicial, este excluído do critério acima mencionado relativo a remédio que se dirige contra decisões já transitadas em julgado, não são recursos. ${ }^{20}$

O recurso é um direito exercitado pelas partes, representando um verdadeiro desdobramento do direito de ação, ou seja, é o meio de ensejar, dentro do mesmo processo, a reforma, a invalidação, o esclarecimento ou a integração de decisão judicial, visando à obtenção de uma reforma da decisão judicial. ${ }^{21}$

Logo, os recursos são tradicionalmente conceituados como um meio de impugnação de uma decisão judicial dentro do mesmo processo, sem que seja estabelecida uma nova relação processual, enquanto a ação autônoma de impugnação tem como principal característica a instauração de uma nova relação jurídica em um novo processo, cujo mérito é diverso do objeto do processo, no qual foi proferida a decisão que se quer impugnar.

\footnotetext{
${ }^{19}$ BARBOSA MOREIRA, 2010. item 134, p. 229-230.

${ }^{20}$ Ibidem, item 135, p. 232-233.

${ }^{21}$ Ibidem, p. 233; BUENO, Cassio Scarpinela. Curso sistematizado de direito processual civil. 2. ed. São Paulo: Saraiva, 2010. p. 35.
} 
O recurso não se confunde com a ação autônoma de impugnação, visto que não dá origem à formação de uma nova relação processual, se insere na própria relação jurídica em que foi proferida a decisão recorrida, impedindo o trânsito em julgado e dando prosseguimento à ação. ${ }^{22}$

O artigo 496 do Código de Processo Civil enumera os recursos e daí se extrai que não há a instauração de um novo processo, mas, sim, um prolongamento do processo pendente.

\subsection{Objetivo de recorrer}

O objetivo do recurso é fazer desaparecer a situação prática acarretada pela decisão desfavorável. O recurso visa reformar ou anular a decisão judicial, sem a necessidade da instauração de um novo processo, ou seja, provoca a extensão daquele já instaurado. ${ }^{23}$ Desta forma, após ser proferida a sentença, há uma continuidade do processo, não ocorrendo o trânsito em julgado da decisão.

Nas palavras de Francesco Carnelutti, "l'appello é fatto per corregere gli errori eventualmente commessi nella prima decisione. Lo stesso nome di appello (da appellare, chiamare) allude al rivolgersi che fa la parte a un altro giudice affinché giudichi meglio del giudice che ha già giudicato”. Logicamente, aqueles erros que o juízo a quo possa ter cometido podem ser tolhidos pelo juízo ad quem, e basta a impugnação para tirar o valor do julgado, é a via livre para fazer aquilo que poderia e deveria fazer o primeiro juiz, e assim por decidir segundo a justiça. ${ }^{24}$

Renzo Provinciali aduz que o pressuposto comum de todos os meios de impugnação é o prejuízo, derivado da parte que pretende impugnar a decisão com a finalidade de obter outra decisão, que remova o prejuízo, com a reforma ou a anulação do

\footnotetext{
${ }^{22}$ CHEIM JORGE, Flávio. Teoria geral dos recursos cíveis. 4. ed. São Paulo: RT, 2009. p. 25-26.

23 Ibidem, p. 25-26.

${ }^{24}$ CARNELUTTI, Francesco. Diritto e processo. Padova: Morano, 1959. p. 239.
} 
provimento impugnado. Tal conceito é válido para cada tipo de processo (civil), contencioso ou voluntário, de cognição e de execução, assecuratório ou cautelar. ${ }^{25}$

Crisanto Mandriolo ensina que há duas exigências que se contrapõem entre si: uma se refere à não aceitação do primeiro julgado, quando há dúvida de que este possa estar viciado de qualquer erro, ou simplesmente ser injusto, dando lugar à oportunidade de outro julgamento, a respeito do qual a outra parte poderia surgir com as mesmas dúvidas e as mesmas exigências, com a consequente ulterior oportunidade de outros julgamentos, em uma série que, considerada a falibilidade de cada juízo humano, deveria ser infinita; de outro lado, a exigência contrária do juízo de conhecimento, talvez a certeza: a exigência, em suma, de considerar o julgado como repetível e o seu resultado como definitivo. Esse problema é resolvido por todos os ordenamentos modernos com uma solução de compromisso, ou seja, de estabelecer a definitividade do julgado após uma eventual e única renovação: o duplo grau de jurisdição. ${ }^{26}$

Discorre Nicolò Trocker que uma das grandes questões que acompanha o debate da ciência processualista, uma vez elevada à autonomia da ação em relação ao direito material, diz respeito à configuração como direito de obter uma decisão jurisdicional de mérito. ${ }^{27}$ É nesse sentido que o direito de recorrer do indivíduo faz com que ele procure a justiça ao propor a ação, não somente visando uma decisão de mérito na primeira instância, mas também por obtê-la em segunda instância, recorrendo quando a decisão não lhe foi favorável.

A crise na prestação da tutela jurisdicional é subproduto do direito instrumental, visto ser estarrecedora a quantidade de meios impugnativos de decisões judiciais que aportam nos tribunais, ${ }^{28}$ o que faz gerar tão somente insegurança jurídica, visto que os litigantes não atingem as pretensões perseguidas e a tão esperada paz social em tempo razoável.

\footnotetext{
${ }^{25}$ PROVINCIALI, Renzo. Trattato del processo civile. Napoli: Morano, 1962. p. 19.

${ }^{26}$ MANDRIOLI, Crisanto. Corso di diritto processuale civile. 11. ed. Torino: Giappichelli. 1997. p. 345346.

${ }^{27}$ TROCKER, Nicolò. Dal giusto processo all'effettività dei rimedi: $l$ '< $<$ azione $>$ nell'elaborazione della Corte europea dei diritti dell'uomo. Parte seconda. Rivista Trimestrale di Diritto e Procedura Civile, Milano, anno LXI, n. 2, p. 439, 2007.

${ }^{28}$ FIGUEIRA JÚNIOR, 2010, p. 269.
} 


\subsection{Duplo grau de jurisdição}

Os contornos e os limites do duplo grau de jurisdição são delineados na Constituição Federal. Para se efetivar o binômio segurança-justiça, os litígios não poderiam perpetuar-se no tempo, sob o pretexto de conferirem maior segurança àqueles que procuram por justiça. Assim, o objetivo do duplo grau é fazer a adequação entre a realidade no contexto social da sociedade e o direito à segurança e à justiça das decisões judiciais. $^{29}$

Nossa Constituição Federal aponta a opção pela possibilidade de recursos contra decisões judiciárias: a) na divisão estrutural da organização judiciária inserta no artigo 92, em que se atribui competência a tribunais para o julgamento de recursos; b) quando estabelece a competência dos tribunais superiores para julgamento do recurso ordinário, do extraordinário e do especial, conforme os artigos 102, II e III, e 105, II e III; c) quando dispõe sobre os recursos a serem endereçados aos tribunais que integram a Justiça da União (Superior Tribunal Militar, Tribunal Superior do Trabalho, Tribunal Superior Eleitoral e Tribunais Regionais Federais), este último com previsão no artigo 108, II; d) quando faz a previsão de órgãos inferiores e superiores nas Justiças Estaduais; e) na redação do inciso LV do art. 5. ${ }^{\circ}$, que garante os princípios processuais do contraditório e da ampla defesa, com os meios e recursos inerentes a este último.

O que se denota é que a nossa Constituição Federal atual não garante o duplo grau ilimitadamente como o fazia a Constituição Imperial de $1824,{ }^{30}$ o que se verifica, por exemplo, quando enumera casos em que cabe o recurso ordinário ou extraordinário, ao afirmar, entre outras hipóteses, que as decisões do Tribunal Superior Eleitoral são irrecorríveis, salvo quando contrariem a Constituição Federal, conforme prevê o § $3 .^{\circ}$ do artigo 121. A lei ordinária não pode suprimir os princípios previstos na Carta Magna, cabendo ao legislador infraconstitucional tornar efetiva aquela regra maior, de maneira a imprimir operatividade ao princípio do duplo grau. ${ }^{31}$

\footnotetext{
${ }^{29}$ NERY JR., Nelson. Teoria geral dos recursos. 7. ed. São Paulo: RT, 2014. item 2.3, p. 60.

${ }^{30}$ Essa regra encontra-se no CF/1824, Art. 158: "Para julgar as causas em segunda, e última instância haverá nas Províncias do Império as Relações, que forem necessárias para comodidade dos Povos”, a qual não foi seguida pelas demais Constituições brasileiras.

${ }^{31}$ NERY JR., 2014. p. 60-62. Para Ada Pellegrini Grinover: "o duplo grau de jurisdição, ainda que não configure - ad argumentandum - garantia constitucional autônoma, faz parte, sem dúvida alguma, daquele conjunto de garantias que configuram o devido processo legal" (Os princípios constitucionais e o Código de Processo Civil. São Paulo: Bushatsky, 1975. p. 143-144.
} 
A lei federal infraconstitucional pode criar, extinguir, modificar ou ampliar os meios de impugnação das decisões, sem, no entanto, fazê-lo em relação aos recursos previstos e regulados expressamente pela Constituição Federal. ${ }^{32}$

Para Araken de Assis, uma das justificativas da necessidade do duplo grau de jurisdição está na circunstância de a decisão de primeira instância estar sujeita a erros e imperfeições, em que o reexame pelo órgão ad quem pode eventualmente corrigir o vício do juízo (error in judicando), ou vício de atividade (error in procedendo). ${ }^{33}$ Trata-se de uma justificação política do princípio, a qual invoca maior probabilidade de acerto decorrente da sujeição dos pronunciamentos judiciais ao crivo da revisão. ${ }^{34}$

No entanto, salienta Francesco Carnelutti que nem sempre há no sistema do duplo grau a garantia de conformidade de duas ou mais sentenças, pois, se o juiz de segundo grau decide diversamente do juiz de primeiro grau, esta segunda decisão não passará por uma ulterior instância e, em tal caso, a segunda sentença deve prevalecer sobre a primeira. A razão de tal prevalência não está no vínculo de subordinação hierárquica entre os magistrados de diversos graus, inconciliável com o princípio moderno de independência dos juízes, mas principalmente na menor probabilidade de erros que é ínsita no juízo de segundo grau, seja pelas maiores garantias pessoais constitucionais dos magistrados de segundo grau (colegialidade, maior idade, seleção etc.), seja porque é mais fácil para o segundo juiz valorar objetivamente os resultados, para não recair nos mesmos erros do juízo de primeiro grau. ${ }^{35}$

Segundo Cândido Rangel Dinamarco, os fundamentos de ordem políticoinstitucional do princípio do duplo grau de jurisdição consistem: a) na uniformização da jurisprudência, quanto à interpretação da Constituição e da lei federal, o que não seria possível caso os numerosos juízos de primeiro grau decidissem em caráter definitivo; b) na necessidade de se colocarem os juízes de grau inferior sob o controle dos superiores, a fim de evitar desmandos e legitimar a própria atuação do Poder Judiciário como um todo. Em decorrência desse contexto, o princípio do duplo grau de jurisdição é indispensável ao

${ }^{32}$ Como é o caso dos recursos extraordinário (CF, art. 102, III) e especial (CF, art. 105, III). NERY JR., 2014. item 2.3, p. 62.

${ }^{33}$ ASSIS, Araken de. Manual dos recursos. 2. ed. São Paulo: RT, 2008. p. 72. Nesse sentido: Enciclopedia italiana. Milano: Istituto Giovanni Treccani, 1939. p. 730.

${ }^{34}$ BARBOSA MOREIRA, 2010. v. 5, item 138, p. 237.

${ }^{35}$ CARNELUTTI, Francesco. Appello civile. Enciclopedia italiana. Milano: Casa Editrice Bestetti \& Tumminelli, 1939. p. 730. 
equilíbrio entre a segurança jurídica, espelhada na outorga da tutela jurisdicional com a maior brevidade possível, e a ponderação nos julgamentos, ou seja, com julgados confiáveis e de qualidade. ${ }^{36}$

No entanto, na prática, nada assegura a superioridade, o acerto (a justiça!) e a correção do pronunciamento feito em segunda instância, supostamente emitido para corrigir o pronunciamento de primeiro grau, uma vez que o exame do litígio se baseia nas provas trazidas e no direito alegado, e, em função do afastamento da oralidade, sofre deficiências em segunda instância. ${ }^{37}$

Observa Salvatore Satta que, teoricamente, o reexame da controvérsia, no esforço de aproximar a justiça da decisão, poderia chegar ao infinito, pois não existe de fato algum meio que seja a prova absoluta de justiça. Entretanto, a ordem jurídica é uma ordem prática que necessita de certeza, como de justiça, e, portanto, deve em um dado momento solucionar a controvérsia de modo a não oferecer mais a possibilidade de modificação. Salienta o processualista que o Código de Processo Civil italiano, que regula o procedimento ordinário, prevê dois graus de exame pleno, suficientes para assegurar um máximo de probabilidade de justiça da decisão. Na Itália é permitido em um terceiro grau: cassazione e conseguente giudizio di rinvio. ${ }^{38}$

O princípio em questão indica que, por via de recurso, há a possibilidade de revisão de causas já julgadas pelo juiz de primeiro grau, ou primeira instância, correspondendo à denominada jurisdição inferior, ou seja, garante um novo julgamento por parte dos órgãos de segundo grau, também chamados de segunda instância.

O duplo grau de jurisdição normalmente não assegura dois juízos sobre todas as questões discutidas no processo, mas garante somente a possibilidade de a controvérsia, compreendida em sua totalidade, passar por um duplo exame. ${ }^{39}$ No direito italiano ensina Mario Vellani que a consagração do duplo grau de jurisdição "non esige che ogni singola questione venga esaminata due volte: è la controversia nel suo complesso che deve poter

\footnotetext{
${ }^{36}$ DINAMARCO, Cândido Rangel. Instituições de direito processual civil. São Paulo: Malheiros, 2009a, v. 1, p. 243.

${ }^{37}$ LASPRO, Oreste Nestor de Souza. Duplo grau de jurisdição no direito processual civil. São Paulo: RT, 1995. p. 102.

${ }^{38}$ SATTA, Salvatore. Diritto processuale civile. Padova: Cedam, 1981. p. 443-444.

${ }^{39}$ MALLET, Estêvão. Sentença terminativa e julgamento imediato. In: NERY JR., Nelson; WAMBIER, Teresa Arruda Alvim (Coord.). Aspectos polêmicos e atuais dos recursos cíveis e de outros meios de impugnação a decisões judiciais. São Paulo: RT, 2003. v. 7, p. 181.
} 
passare [...] atraverso due gradi”. ${ }^{40}$ Isso significa que o duplo grau garante o reexame das questões que fazem parte das razões recursais, aquilo que não for impugnado pelo recorrente não será objeto de reexame.

Em outras palavras, o princípio do duplo grau está fundado na possibilidade de a decisão de primeiro grau ser injusta ou estar errada, quando se verifica a necessidade de reforma, que somente poderá ser feita em grau de recurso. A manutenção desse princípio no ordenamento jurídico é de natureza política, pois nenhum ato estatal deve ficar livre do controle devido.

Conforme pondera Nelson Nery Junior, o princípio do duplo grau de jurisdição está intimamente ligado com a preocupação do ordenamento jurídico de evitar a possibilidade de haver abuso de poder por parte do juiz que profere a decisão em primeiro grau, o que poderia ocorrer se a decisão não estivesse sujeita à revisão por outro órgão do Poder Judiciário. ${ }^{41}$

O significado desse princípio é que toda decisão proferida por um juiz de primeiro grau é passível de revisão em segunda instância, ou seja, toda decisão proferida pelo juízo a quo pode ser revista, em sentido amplo, delimitado pelo recorrente sucumbente, pelo juízo ad quem.

Para Luigi Paolo Comoglio, o duplo grau de jurisdição tem o significado de dupla cognição de mérito de uma mesma controvérsia efetuada por dois juízes diversos, habitualmente, mas não necessariamente, um inferior e outro superior. Na teoria, entendese que uma controvérsia, submetida à cognição de um juiz de primeiro grau, possa ser sucessivamente submetida à cognição de outro juízo, a fim de ser inteiramente reavaliada e decidida com uma decisão destinada a prevalecer sobre a primeira. ${ }^{42}$

O jurista italiano sustenta que a garantia do duplo grau de jurisdição está profundamente radicada nas tradições europeias ocidentais, como também não certamente ignorada ou desconhecida nos sistemas da common law, a qual exige que, nos confrontos das decisões pronunciadas pelos juízes de primeira instância, seja constantemente

\footnotetext{
${ }^{40}$ VELLANI, Mario. Appello (Diritto processuale civile). Enciclopedia del Diritto. Varese: Giuffrè, 1958. II, p. 719.

${ }^{41}$ NERY JR., Nelson, 2014. item 2.3, p. 58.

42 COMOGLIO, Luigi Paolo. Il doppio grado di giudizio nelle prospettive di revisione costituzionale. Rivista di Diritto Processuale, Pad.va, seconda serie, n. 2, p. 328, apr.-giu. 1999.
} 
assegurada uma oportunidade de revisão e de reexame em um novo juízo, mediante uma impugnação proposta a um juízo superior. ${ }^{43}$

A princípio, o duplo grau pressupõe dois órgãos judiciários em posição de hierarquia, sendo um inferior e outro superior, sendo o primeiro grau composto de juízes singulares e o segundo grau de colegiado composto de três magistrados, supostamente mais experientes. ${ }^{44}$ Os termos jurisdição inferior e jurisdição superior indicam apenas a competência desta última para julgar novamente as causas já decididas em primeiro grau competência de derrogação, sem qualquer possibilidade de prévia interferência sobre o modo como o juiz decidirá. Qualquer que seja o grau de jurisdição exercido, o juiz tem independência jurídica, não ficando adstrito às decisões dos tribunais de segundo grau, julgando apenas em obediência ao direito e à sua consciência jurídica. ${ }^{45}$

Há casos em que o duplo grau se estabelece entre órgão monocrático e órgão colegiado, porém todos de primeiro grau, como é o caso prescrito no $\S 1 .^{\circ}$ do artigo 41 da Lei 9.099, de 26.09.1995, o qual estabelece que contra sentença do Juizado Especial de Pequenas Causas “o recurso será julgado por uma turma composta por três Juízes togados, em exercício no primeiro grau de jurisdição, reunidos na sede do Juizado” 46

Em nosso ordenamento jurídico, o princípio do duplo grau de jurisdição foi previsto pela primeira vez na Constituição do Império em 1824, cujo artigo 158 prescrevia: “para julgar as causas em segunda e última instância haverá nas Províncias do Império as Relações, que forem necessárias para comodidade dos povos”.

A Constituição de 1824 imperava em um ambiente de baixo constitucionalismo, tolerou a exigência de alçada (summa gravaminis) na apelação, como se infere do artigo 646 do Decreto n. ${ }^{\circ}$ 737, de 25.11.1850, cuja regra era aplicável às causas comerciais, e a partir do Decreto n. ${ }^{\circ}$ 763, de 19.09.1890, às causas civis, diploma que vigorou em alguns Estados-membros até o Código de Processo Civil de 1939. Todo esse mecanismo é compatível, sob certas condições, com os direitos da Constituição Federal de $1988 .{ }^{47}$

\footnotetext{
${ }^{43}$ COMOGLIO, Luigi Paolo. Garanzie costituzionali e "giusto processo" (modelli a confronto). Revista de Processo. São Paulo, ano 23, n. 90, p. 115, abr.-jun. 1998.

44 "No entanto, o atributo da experiência e o da sabedoria acumulada por força de numerosos julgamentos não se estende a todos magistrados que integram o segundo grau, vez que este também tem em sua composição membros da advocacia e do Ministério Público" (ASSIS, 2008. p. 72).

${ }^{45}$ CINTRA, Carlos de Araújo; DINAMARCO, Cândido Rangel; GRINOVER, Ada Pellegrini. Teoria geral do processo. 26. ed. São Paulo: Malheiros, 2010. p. 80.

${ }^{46}$ LASPRO, 1995. p. 20.

${ }^{47}$ ASSIS, 2008. p. 76. No mesmo sentido: NERY JR., 2014. item 2.3, p. 60-61.
} 
O princípio do duplo grau de jurisdição somente se efetiva se e quando o vencido apresentar recurso contra a decisão de primeiro grau, ou melhor, há necessidade de nova provocação do órgão jurisdicional por aquele que foi desfavorecido pela decisão. Somente em casos previstos em lei, a jurisdição superior pode atuar sem provocação da parte, tendo em vista interesses públicos relevantes a exemplo do caput do artigo 475 do Código de Processo Civil, ou seja, quando ocorre a “devolução oficial”, ou "remessa necessária”, que alguns textos legais denominam de "recurso de ofício”, porém indevidamente. ${ }^{48}$

Segundo Eduardo Cambi, “o argumento de que a Constituição, ao prever os recursos especial e extraordinário, teria assegurado o duplo grau de jurisdição é insubsistente”, uma vez que os tribunais superiores, ao examinarem esses recursos, não podem apreciar e julgar toda a matéria decidida, mas somente aquelas previstas nos artigos 102, III, e 105, III, da Constituição Federal, o que exclui, de imediato, todas as questões de fato que dependam do reexame de provas. ${ }^{49}$

Não significa ofensa ao duplo grau ou supressão de um grau de jurisdição o fato de o artigo 544, § 3. ${ }^{\circ}$, do Código de Processo Civil permitir ao Supremo Tribunal Federal e Superior Tribunal de Justiça o julgamento direto do mérito do recurso extraordinário e recurso especial quando examina e dá provimento a agravo de instrumento a ser interposto contra indeferimento daqueles recursos, pois o tribunal superior apenas abrevia o procedimento por medida de economia processual, visto que a competência tanto para julgar o agravo quanto para os recursos excepcionais é do próprio tribunal superior. ${ }^{50}$

Também o artigo 515, § 3. ${ }^{\circ}$, do mesmo diploma legal permite que nos casos de extinção do processo sem julgamento do mérito o tribunal julgue desde logo a lide, se a causa versar questão exclusivamente de direito e estiver em condições de imediato julgamento, o que equivale conferir ao tribunal competência originária. ${ }^{51}$

No direito italiano ensina Salvatore Satta que o duplo exame não significa um duplo exame de mérito, pois a exigência da lei é satisfeita quando esse exame tenha revisto uma decisão de um juiz, qualquer que seja. Assim poderá ocorrer que um juiz de primeiro

${ }^{48}$ CINTRA, DINAMARCO et GRINOVER, 2010. p. 82.

49 CAMBI, Eduardo. Efeito devolutivo da apelação e duplo grau de jurisdição. In: MARINONI, Luiz Guilherme; DIDIER JR., Fredie. (Coord.). A segunda etapa da reforma processual civil. São Paulo: Malheiros, 2001. p. 248.

50 Se no julgamento do agravo de instrumento, contra decisão que indeferiu no grau de origem, o processamento do RE ou do REsp, o STF ou o STJ tiver que lhe dar provimento, constando no instrumento, todos os elementos necessários ao julgamento do próprio RE ou REsp, o tribunal poderá julgar o recurso excepcional, encurtando o procedimento (NERY JR., 2014. item 2.3, p. 65).

${ }^{51}$ NERY JR., 2014. item 2.3, p. 65. 
grau não tenha decidido o mérito, por ter acolhido uma causa de nulidade, por exemplo. $\mathrm{O}$ juiz de segundo grau, ao contrário, poderá e deverá decidir o mérito, sem que por isso ocorra a violação do princípio do duplo grau. Somente em casos taxativamente determinados, quando o juiz de segundo grau encontrar um erro ou um vício da sentença ou do processo de primeiro grau, com base no qual se pode entender que houve uma falta no primeiro grau, deve reenviar a causa ao juiz de primeiro grau. ${ }^{52}$

O princípio do duplo grau é de ordem pública, uma vez que adotado pelo nosso sistema jurídico, o que significa que as partes não podem estabelecer o cabimento de apelação onde a lei estipula ser última instância, não pode criar um terceiro grau, nem suprimir o segundo. Também não se vislumbra derrogação do princípio do duplo grau quando a competência é originária dos tribunais superiores, pois, se a competência foi atribuída ao órgão superior de jurisdição, em tese se está conferindo maior segurança ao julgamento, visto que a decisão será proferida por órgão colegiado, por julgadores possuidores de grande experiência. ${ }^{53}$

\subsection{Duplo grau de jurisdição e devido processo legal}

A moderna doutrina processualística trata o duplo grau como garantia constitucional do devido processo legal, com enfoques do direito de defesa, mas sempre com a ressalva de que o princípio deve ser de aplicação moderada pelos ordenamentos jurídicos, de maneira a não distanciar-se da realidade contemporânea visando à busca de uma justiça mais efetiva e rápida, sem perder de vista a segurança. ${ }^{54}$

Na visão de Orestes Nestor de Souza Laspro, os princípios do duplo grau de jurisdição e do devido processo legal, apesar de estarem ligados entre si, não traduzem relação de dependência ou continência, dado que é possível assegurar qualquer um dos dois princípios sem o outro. Conclui que pode haver um processo obediente ao princípio do devido processo legal sem que haja, necessariamente, previsão do duplo grau de jurisdição, e salienta que entre os elementos essenciais ao devido processo legal não se pode incluir o duplo grau de jurisdição, que é mero elemento acidental. No entanto, se na

\footnotetext{
52 SATTA, 1981. p. 451.

${ }^{53}$ NERY, 2014. item 2.3, p. 66.

${ }^{54}$ Ibidem, item 2.3, p. 63.
} 
Constituição Federal consta a garantia do duplo grau de jurisdição, sobrevindo lei que impeça o acesso aos meios de impugnação, esta será inconstitucional porque desobedece a esse princípio, e não porque desatende ao devido processo legal. ${ }^{55}$

Na Itália, Luigi Paolo Comoglio, ao discorrer sobre o acesso à justiça e garantia internacional do due processo of law, menciona que a garantia constitucional de acesso à justiça não inclui necessariamente o direito a uma jurisdição de segundo grau, ou seja, a um sistema de impugnações, de rito e de mérito. Salienta que o “right of appeal” não é formalmente considerado como componente essencial e indefectível de processo justo, seja ele civil ou penal, o direito de a parte sucumbente propor os meios apropriados de gravame a um juiz de grau superior, para anular ou reformar uma decisão de primeira instância, está teoricamente incluso na garantia de defesa. ${ }^{56}$

\subsection{Argumentos favoráveis do duplo grau de jurisdição}

As razões para a utilização das vias recursais são extremamente diversas, incluindose aqui a sincera convicção de que o órgão a quo decidiu de maneira errônea, indo até a litigância de má-fé, pressão sobre o adversário para forçá-lo a um acordo, inclusive quando a vontade de recorrer for do advogado, receoso de que a derrota venha a atingir o seu prestígio profissional.

Salienta Cândido Rangel Dinamarco que existe a conveniência psicológica de oferecer aos perdedores mais uma oportunidade de êxito, uma vez que confinar os julgamentos em um só grau de jurisdição significaria uma contenção de litigiosidades, permitindo que os estados de insatisfação e desconfiança perpetuassem, o que levaria a prováveis ocorrências de revoltas, especialmente no Brasil, em que os órgãos de primeiro grau são monocráticos e os tribunais julgam ordinariamente em colegiado, pois pressupõe-

${ }^{55}$ LASPRO, 1995. p. 95-97. Nesse sentido, informa Alessandro Pizzorusso que a constituição italiana garantiu o recurso de cassação sem a previsão do duplo grau de jurisdição (Sul principio del doppio grado di giurisdizione. Rivista di Diritto Processuale. Padova, n. 1, v. 33, p. 36, 1978).

${ }^{56}$ COMOGLIO, Luigi Paolo. Accesso alle corti e garanzie costituzionale. In: YARSHELL, Flávio Luiz; MORAES, Maurício Zanoide de (Org.). Estudos em homenagem à Professora Ada Pellegrini Grinover. São Paulo: DPJ Editora, 2005. p. 278-279. 
se que há uma maior probabilidade de acerto nos julgados realizados por juízes mais numerosos e mais experientes. ${ }^{57}$

Nessa mesma linha de raciocínio, Vittorio Denti e Michele Taruffo afirmam que, em relação ao sistema judicial italiano, o centro de gravidade da causa não é, como deveria ser em um sistema equilibrado, o juízo de primeiro grau, porque a falta de fidúcia das decisões naquela sede leva ao uso excessivo dos remédios, seja em segunda ou terceira instância. $^{58}$

No Brasil, Orestes Nestor de Souza Laspro aduz que, a princípio, no segundo grau de jurisdição, os magistrados possuem mais experiência e vivência por exercerem suas funções há mais tempo, conforme aparece nas organizações judiciárias em que a carreira do magistrado tem início na primeira instância. ${ }^{59}$

Outro ponto vantajoso é que os meios de impugnação auxiliam na realização do escopo social de pacificação do conflito, uma vez que uma segunda análise proporciona à parte sucumbente maior conformismo com a decisão final.

A prática ensina que o magistrado de primeiro grau procura exercer a função jurisdicional da melhor forma possível, pelo fato de saber que as suas decisões serão reavaliadas pelo órgão ad quem. ${ }^{60} \mathrm{O}$ trabalho tende a ter resultados melhores diante da possibilidade de ser reexaminado no tribunal, com a propositura de um recurso.

No segundo grau, o reexame de uma questão é realizado com base nas provas constantes dos autos do processo e no direito alegado pelas partes, em razão do afastamento da oralidade, não se podendo afirmar que trará melhores resultados ao inconformismo de quem recorre.

\subsection{Argumentos contrários do duplo grau de jurisdição}

\footnotetext{
${ }^{57}$ DINAMARCO, 2009a. v. 1, p. 243. No mesmo sentido, José Carlos Barbosa Moreira: “A justificação política do princípio tem invocado a maior probabilidade de acerto decorrente da sujeição dos pronunciamentos judiciais ao crivo da revisão. É dado da experiência comum que uma segunda reflexão acerca de qualquer problema frequentemente conduz a mais exata conclusão, já pela luz que projeta sob ângulos até então ignorados, já pela oportunidade que abre para a reavaliação de argumentos a que no primeiro momento talvez não se tenha atribuído o justo peso” ( 2010. item 138, p. 237).

${ }^{58}$ DENTI et TARUFFO, 1986. p. 291.

59 No entanto, há exceções, como é o caso das sentenças proferidas nos Juizados Especiais de Pequenas Causas, conforme $\S 1$. $^{\circ}$ do art. 41 da Lei 9.099, de 26 de setembro de 1995. Cf. LASPRO, 1995. p. 99-100.

${ }^{60}$ FRANCO MONTORO, 2005, p. 24.
} 
Segundo José Carlos Barbosa Moreira, desde tempos remotos, não faltam críticas ao sistema do duplo grau de jurisdição. Os adversários desse princípio alegam que: se os órgãos superiores são presumivelmente mais capazes de fazer boa justiça, neste caso seria melhor confiar-lhes diretamente a tarefa de julgar as causas, ou, se não gozam de tal presunção, a devolução da matéria ao seu conhecimento é medida contraproducente pelo risco que gera de substituir-se uma decisão certa por outra errônea. ${ }^{61}$

Outra desvantagem é a excessiva duração do processo, que configura, indiscutivelmente, uma denegação da justiça, provocando danos econômicos às partes, auxiliando aquele que demanda sem razão, o que constitui verdadeira ofensa ao devido processo legal. $^{62}$

Nas legislações que admitem a dilação probatória em segunda instância, o duplo grau dificulta a busca da verdade real, uma vez que são naturais as dificuldades de produção de provas e consequente divergência entre os resultados obtidos em primeira e segunda instância, em especial com as provas orais, pois, com o decorrer do tempo e afastamento dos fatos ocorridos a ser demonstrados em juízo, a lembrança das testemunhas e das próprias partes se desvanece, o que dificulta a atividade dos julgadores. ${ }^{63}$

No tocante à desejável execução imediata da sentença, o duplo grau também impede a consagração de outro valor mais relevante, que é a celeridade processual. ${ }^{64}$

Desprestígio da primeira instância, pois suas decisões sempre podem ser impugnadas. Se a decisão for mantida, a atividade decorrente da análise recursal foi inútil; se ocorrer a reforma, criar-se-á insegurança jurídica com desprestígio do órgão inferior. ${ }^{65}$

No direito italiano, Mauro Cappelletti foi mais enfático propondo uma reforma da organização judiciária, com a supressão do recurso de apelação e a manutenção somente do recurso de cassação. ${ }^{66}$

\footnotetext{
${ }^{61}$ BARBOSA MOREIRA, 2010. item 138, p. 237.

${ }^{62}$ LASPRO, 1995. p. 114-115.

${ }^{63}$ Ibidem, p. 116-117. No mesmo sentido: PIZZORUSSO, 1978, p. 46.

${ }^{64}$ MEDINA, Paulo Roberto de Gouveia. Duplo grau de jurisdição e efeito suspensivo. In: NERY JR., Nelson; WAMBIER, Tereza Arruda Alvim (Coord.). Aspectos polêmicos e atuais dos recursos cíveis de acordo com a Lei 9.756/98. São Paulo: RT, 1999. p. 486.

${ }^{65}$ FRANCO MONTORO, 2005, p. 24. Esse autor acrescenta que: Inexiste a garantia de que o último a julgar proferirá o melhor julgamento, além do que a utilização dos meios de impugnação com a finalidade exclusivamente procrastinatória.
} 


\subsection{Da análise dos argumentos favoráveis e contrários do duplo grau de jurisdição e do formalismo no juízo de admissibilidade dos recursos}

Na doutrina italiana, Edoardo F. Ricci afirma que o primeiro ponto relevante se dá na consideração da ideia do duplo grau como irrenunciável garantia de justiça, que, se hoje é colocada em dúvida no seu fundamento ideológico e político, subsiste uma crise no terreno jurídico-positivo que é própria do instituto. O segundo ponto de relevo concerne à justificação racional do duplo grau, do ponto de vista da técnica processual. Sob o aspecto ideológico, do plano da técnica do processo o duplo grau se justifica a ponto de se ter a segunda decisão mais aceitável que a primeira, pois recorre-se à ideia de que a segunda decisão tenha maior fidúcia por ser proveniente de um juízo superior.

Salienta o mestre italiano que o primeiro aspecto, concernente à crise do princípio do duplo grau no direito positivo, impede de obter em defesa do próprio princípio, com a pura e simples conservação da estrutura existente, e depois de lhe reconhecer a força, que sempre está no fato de manter as coisas como são. Na realidade, o duplo grau que resiste no jus quo ultimur, se de um lado é o mais grave estorvo visto pelas suas críticas, de outro lembra uma coisa pequena a aspirar um comprometido e desafiador apoio, assim como é; manter firme a ideia do duplo grau como garantia irrenunciável significa agitar um modelo diferente da disciplina vigente, tendente a restituir à apelação, a atitude de assegurar o seu fim originário. ${ }^{67}$

O argumento que fundamenta a justificação do duplo grau sobre as exigências de justiça foi, há muito, eficazmente rebatido: se de fato é indiscutível que uma repetição de juízo por mais vezes oferece maior possibilidade de individuar a solução mais correta a dar ao caso, não demonstra, no entanto, que a última solução encontrada seja a mais justa. ${ }^{68}$

Entre a conservação do duplo grau ou a sua abolição, existem múltiplas hipóteses de evolução não transparente, nem do ponto de vista científico, nem do ponto de vista lato sensu político. Além disso, a crítica, que o princípio do duplo grau pode suscitar quando as duas fases sucessivas do processo são, em si, igualmente bem construídas e bem

\footnotetext{
${ }^{66}$ No original: "La Corte di cassazione si articola in una Corte di cassazione centrale e sezioni distaccate correspondenti alle soppresse corti di appello" (Parere iconoclastico sulla riforma del processo civile italiano. Giustizia e società. Milano: Edizioni di Comunità, 1972. p. 120).

${ }^{67}$ RICCI, Edoardo F. Il doppio grado di giurisdizione nel processo civile. Rivista di Diritto Processuale. Padova, n. 1, v. 33, p. 62-63, 1978.

68 PIZZORUSSO, 1978, p. 45.
} 
estruturadas, é destinada a não valer mais, onde o sistema renuncia por qualquer razão a tornar a primeira instância a melhor possível para recuperar plenamente as garantias necessárias somente em momento sucessivo, quando a decisão de primeiro grau não for aceita pelo sucumbente. $^{69}$

Outro aspecto mencionado por Alessandro Pizzorusso é o de considerar os reflexos que o princípio do duplo grau determina sobre a organização judiciária no sentido de justificar a hierarquia da estrutura judiciária, das relações entre os ofícios que pertencem aos juízes de primeiro grau e aqueles concernentes aos juízes de segunda instância. ${ }^{70}$

No Brasil, pondera Araken de Assis que existem dois fatores que na verdade se mostram estranhos ao domínio do duplo grau, mas que completam o panorama e devem ser considerados perante o todo, que influenciam a notória sensação de que as causas se prolongam indefinidamente, submetidas a sucessivos reexames: a) o objetivo de uniformizar a aplicação da lei federal (artigo 105, III, da Constituição Federal); e b) a subsistência do controle difuso de constitucionalidade, sem embargo com controle concentrado, que implica a manutenção do recurso extraordinário para firmar a última palavra do Supremo Tribunal Federal (artigo 102, III, da Constituição Federal).

Salienta o processualista que o princípio do duplo grau, tomado pela ideologia da recorribilidade e desviado de seus rumos por dois generosos tribunais de superposição, abdicou da sobriedade que lhe revestia a sua concepção originária. O aparecimento constante de questões federais e constitucionais simultâneas nas causas mais banais, que se baseiam em razões tipificadas na Constituição Federal, gera um “duplo” grau exponencial: há o terceiro grau despontado no Superior Tribunal de Justiça (artigo 105, III, da Constituição Federal) e um quarto grau a cargo do Supremo Tribunal Federal (artigo 102, III, da Constituição Federal). ${ }^{71}$ Cabe aqui ressaltar que, além do aumento da densidade demográfica, houve uma politização da população que, com apoio nos princípios fundamentais constitucionais, atualmente luta por seus direitos e interesses.

Em razão desse fenômeno que gera um número gigantesco de recursos para os tribunais de superposição, o juízo de admissibilidade dos recursos passa por um crivo acurado, cada vez mais propenso a eliminar obstáculos ao cabimento do recurso especial e

\footnotetext{
${ }^{69}$ RICCI, 1978, p. 64.

${ }^{70}$ PIZZORUSSO, 1978, p. 47-48.

${ }^{71}$ ASSIS, 2008. p. 78-79.
} 
do recurso extraordinário, gerando uma jurisprudência defensiva, muitas vezes com um excesso de formalismo, que se analisará mais adiante. 


\section{PRINCÍPIOS PROCESSUAIS RELACIONADOS AO DIREITO DE RECORRER}

Para dar forma e caráter aos sistemas, a ciência processual moderna fixou princípios fundamentais, e alguns deles são comuns a todos os sistemas, enquanto outros, mais específicos, são aplicáveis em determinados ordenamentos, ${ }^{72}$ por exemplo, o sistema recursal.

Segundo Cândido Rangel Dinamarco, a técnica processual desenvolveu ao longo dos séculos e da experiência acumulada regras de grande importância, responsáveis pela boa ordem do processo e o correto encaminhamento de suas soluções, e, ao lado dessas regras, há os princípios que funcionam como pilares de apoio, especialmente aqueles de índole político-constitucional. ${ }^{73}$

Salienta o processualista que a Constituição formula princípios com o objetivo de proporcionar o acesso à justiça, oferece garantias e impõe exigências em relação ao sistema processual, que convergem a um núcleo central e comum, que é o devido processo legal, uma vez que a observação dos padrões previamente estabelecidos na Constituição e na lei é oferecer o contraditório, a publicidade, possibilidade de ampla defesa etc. ${ }^{74}$

Os princípios constitucionais estão englobados em um “princípio síntese” que é o princípio do devido processo legal (due process of law), o que significa que dessa fórmula genérica poderiam ser extraídos os demais princípios, dentre eles o princípio do contraditório, ampla defesa, juiz natural etc. ${ }^{75}$

\footnotetext{
${ }^{72}$ Nesse sentido, Carlos de Araújo Cintra, Cândido Rangel Dinamarco e Ada Pellegrini Grinover ensinam que "cada sistema processual se calça em princípios que se estendem a todos ordenamentos e em outros que lhes são próprios e específicos” ( 2010. p. 56).

${ }^{73}$ DINAMARCO, 2009a, p. 200.

${ }^{74}$ Ibidem, p. 202-203.

${ }^{75}$ Nesse sentido, José Carlos Baptista Puoli enfatiza: "Esse enunciado desenvolveu-se no tempo até que passou a ser sistematicamente acolhido pelas constituições modernas, chegando aos nossos dias e encontrando-se positivado na Constituição Federal brasileira de 1988, com o seguinte teor: 'Ninguém será privado da liberdade ou de seus bens sem o devido processo legal' (art. 5. ${ }^{\circ}$, inciso LIV)" (Os poderes do juiz e as reformas do processo civil. São Paulo: Juarez de Oliveira, 2002. p. 64).
} 


\subsection{Princípio da taxatividade recursal}

O princípio da taxatividade diz respeito à criação dos recursos, ou seja, somente a lei federal pode criar recursos no sistema processual civil brasileiro, por força do que dispõe o inciso I do artigo 22 da Constituição Federal, ${ }^{76}$ visto que nenhum ordenamento jurídico pode deixar no âmbito da discricionariedade dos litigantes a instituição dos meios hábeis para impugnar as decisões judiciais. ${ }^{77}$

Enquanto a criação do recurso está adstrita somente à lei federal, até mesmo para fins de uniformização do processo em todo o território nacional, a competência quanto à matéria procedimental, isto é, no tocante à forma do exercício de recorrer, é da esfera estadual. $^{78}$

O princípio da taxatividade também é denominado de princípio da legalidade recursal, a enumeração legal dos recursos existentes é taxativamente prevista em lei. A tarefa de criar, modificar ou extinguir recursos é de competência exclusiva da União, não sendo deixada ao arbítrio das partes, nem à competência dos Estados ou Municípios, tampouco aos regimentos internos dos tribunais. ${ }^{79}$

Dentro das normas de interpretação da legislação, cabe ao intérprete verificar se o rol de hipóteses da lei se trata de um rol exaustivo ou meramente exemplificativo. Se a enumeração for exaustiva, a interpretação é restrita; se for exemplificativa, a interpretação é ampla e genérica. Existem expressões utilizadas pelo legislador que indicam que a enumeração é taxativa, tais como: “apenas”, “unicamente”, “só”, “seguinte”, entre outras expressões que precedem o elenco de hipóteses. ${ }^{80}$

O artigo 496 do Código de Processo Civil enumera os recursos cabíveis no processo civil: a) apelação; b) agravo; c) embargos infringentes; d) embargos de declaração; e) recurso ordinário; f) recurso especial; g) recurso extraordinário; h) embargos de divergência.

Da leitura do artigo 496 do Código de Processo Civil se conclui que a palavra “seguinte” é utilizada para demonstrar que o rol de recursos lá previsto é taxativo, ou seja,

\footnotetext{
${ }^{76}$ BUENO, 2010. p. 47.

${ }^{77}$ ASSIS, 2008. p. 79.

${ }^{78}$ BUENO, 2010. p. 47.

${ }^{79}$ PINTO, Nelson Luiz. Manual dos recursos cíveis. 3. ed. São Paulo: Malheiros, 2004. p. 87.

${ }^{80}$ NERY JR., 2014, item 2.4.2, p. 68.
} 
somente aqueles meios de impugnação são considerados pela lei como recursos, ${ }^{81}$ mas cada qual tem suas próprias características, pressupostos de admissibilidade, procedimento e finalidade dentro do sistema processual. ${ }^{82}$

No entanto, a taxatividade pertence ao sistema legal federal, e não ao Código de Processo Civil, haja vista a existência de outros recursos além dos elencados no artigo 496, que são previstos em leis extravagantes, como é o caso, entre outros: a) embargos infringentes contra sentenças proferidas nas execuções fiscais em causas de alçada, prevista no artigo 24 da Lei n. ${ }^{\circ}$ 6.830, de 22.09.1980; e b) o recurso inominado contra as sentenças civis proferidas nos juizados especiais comuns, conforme artigo 41, caput, da Lei n. ${ }^{\circ}$ 9.099, de 16.09.1995, e nos juizados especiais federais, conforme artigo $5 .^{\circ}$ da Lei n. ${ }^{\circ}$ 10.259, de 12.07.2001.

Flávio Cheim Jorge enfatiza que, mesmo sendo evidente a taxatividade do artigo 496 do Código de Processo Civil, as formas de interposição dos recursos não foram nele mencionadas, o que é demonstrado na possibilidade de interposição de certos recursos de forma adesiva, conforme artigo 500 do Código de Processo Civil, como o caso da apelação, dos embargos infringentes, recurso especial e recurso extraordinário. ${ }^{83}$

Quanto aos “pedidos de reconsideração” e “correições parciais”, uma vez que não são previstos por lei federal, não são recursos em sentido estrito ou medidas jurisdicionais aptas à reforma, anulação ou complementação de decisões judiciais. ${ }^{84}$

Salienta João Batista Lopes que, se o despacho tiver qualquer conteúdo decisório, não pode o juiz admitir pedidos de reconsideração, e o interessado deverá interpor o recurso previsto em Lei. ${ }^{85}$

\subsection{Princípio da colegialidade e das decisões monocráticas proferidas nos tribunais}

\footnotetext{
${ }^{81}$ NERY JR., 2014, p. 68.

${ }^{82}$ ASSIS, 2008. p. 80.

${ }^{83}$ CHEIM JORGE, 2009, p. 216.

${ }^{84}$ BUENO, 2010. p. 48.

${ }^{85}$ LOPES, João Batista. Os poderes do juiz e o aprimoramento da prestação jurisdicional. Revista de Processo. São Paulo, ano IX, n. 35, p. 34, abr.-jun. 1984.
} 
Tradicionalmente, no direito brasileiro, o juiz natural dos recursos é o órgão colegiado. ${ }^{86}$ Pelo princípio da colegialidade, os recursos devem ser julgados por órgãos colegiados dos tribunais, ou seja, pelas câmaras, turmas, seções.

O artigo 557, que trata de exceção, concede ao relator poder de negar seguimento ao recurso, quando manifestamente inadmissível, improcedente, prejudicado ou em confronto com súmula ou com jurisprudência dominante. Neste caso, o relator atua como um porta-voz do colegiado, e o prejudicado poderá requerer que o colegiado se manifeste a respeito, ${ }^{87}$ por meio do recurso de agravo (interno).

A possibilidade de serem proferidas decisões monocráticas pelo relator dos recursos não enseja inconstitucionalidade, uma vez que pode haver o controle desta decisão monocrática pelo órgão colegiado a que pertença o relator. ${ }^{88}$

O Supremo Tribunal Federal já se manifestou nesse sentido:

É legítima, sob o ponto de vista constitucional, a atribuição conferida ao relator para arquivar ou negar seguimento a pedido ou recurso (RISTF, art. 21, § 1. ; Lei 8.038/90, art. 38; CPC, art. 557, redação da Lei 9.756/98), desde que, mediante recurso, possam as decisões ser submetidas ao controle do Colegiado. ${ }^{89}$

O Superior Tribunal de Justiça também decidiu de maneira semelhante: “O julgamento monocrático pelo relator da causa, previsto no art. 557 do Código de Processo Civil, não ofende o princípio do duplo grau de jurisdição", 90

É da tradição constitucional brasileira o julgamento colegiado em segundo grau de jurisdição, estando implícita na estruturação constitucional do Poder Judiciário a pluralidade na composição dos tribunais locais e federais. Em qualquer caso, o relator ou o presidente (atuando isoladamente) deve ter sua atividade, que é “delegada” pelo órgão

${ }^{86}$ MEDINA José Miguel Garcia; WAMBIER, Teresa Arruda Alvim. Recursos e ações autônomas de impugnação. 2. ed. São Paulo: RT, 2011. p. 58. (Processo civil moderno, v. 2) Também nesse sentido, José Carlos Barbosa Moreira ao comentar o artigo 557 às notas 366, salienta: "Presume o legislador que o interessado, na maioria dos casos, se conformará com o pronunciamento do relator. Na verdade, não seria possível subtrair de forma definitiva a apreciação do recurso ao órgão ad quem, sem pôr em xeque a garantia do juiz natural” (2010. item 366, v. 5, p. 683). Segue o mesmo entendimento Cassio Scarpinela Bueno (2010, p. 54.

${ }^{87}$ BARBOSA MOREIRA, 2010. item 366, p. 683.

${ }^{88}$ MEDINA et WAMBIER, 2011. p. 58.

89 STF, Pleno, AGRMI 595/MA, Rel. Carlos Velloso, j. 17.03.1999, DJU 23.04.1999, p. 15.

${ }^{90}$ STJ, 6. ${ }^{a}$ T., AgRg bo Ag 461.330/MG, Rel. Min. Maria Thereza de Assis Moura, j. 16.05.2008, DJ 02.06.2008, p. 1. 
colegiado, submetida, por algum mecanismo, ao controle desse mesmo órgão, o que consiste numa condicionante para que seja compatível com a Constituição. ${ }^{91}$

Na prática, as decisões proferidas monocraticamente nos tribunais sobre pedidos de liminares podem ser impugnadas por meio de recurso ao órgão colegiado, aplicando-se o artigo 39 da Lei n. ${ }^{\circ} 8.038 / 1990 .^{92}$

Contudo, tem-se entendido que, havendo vedação legal ao recurso contra decisão proferida monocraticamente no tribunal, é admitida a impetração de mandado de segurança contra tal pronunciamento judicial. ${ }^{93}$

No entanto, pondera Walter Piva Rodrigues que existe uma improvável vontade de revisar a decisão monocrática atacada, proferida pelo relator, uma vez que há uma nítida acomodação estabelecida entre os membros componentes de Colegiados, seja pela necessidade de dar velocidade à pauta, seja por mero dever de reciprocidade. ${ }^{94}$

\subsection{Princípio da unicidade (ou da singularidade, ou unicorribilidade)}

O princípio da unicidade, também denominado singularidade ou unicorribilidade, significa que contra cada decisão judicial deve existir somente um recurso que lhe é correlato, ou seja, haverá a impossibilidade de simultaneamente se interpor mais de um recurso. Entretanto, pode ocorrer que uma mesma decisão judicial se componha de diversas questões, ou capítulos diversos, haja vista tratar-se de ato jurídico complexo e formalmente uno. Nesses casos, é possível que contra uma mesma decisão composta de

\footnotetext{
${ }^{91}$ TALAMINI, Eduardo. Decisões individualmente proferidas por integrantes dos tribunais: legitimidade e controle ("agravo interno"). In: WAMBIER, Tereza Alvim; NERY JR., Nelson (Coord.). Aspectos polêmicos e atuais dos recursos. São Paulo: RT, 2005. v. 8. Salienta o autor que o poder dos relatores se exerce ad referendum do órgão julgador (por meio de um mecanismo que, a seu ver, não tem natureza recursal).

${ }^{92}$ Acórdão: “A decisão monocrática do relator que defere liminar em ação cautelar incidental ajuizada perante tribunal de segunda instância pode ser impugnada por recurso interno ao colegiado, ainda que ausente a previsão regimental. O art. 39 da Lei 8.038/90, que disciplina o cabimento do agravo interno contra decisão singular proferida por membro do Superior Tribunal de Justiça e do Supremo Tribunal Federal, deve ser aplicado, por analogia, a todos os tribunais do País, em razão do princípio da colegialidade dos tribunais precedentes” (STJ, 2. ${ }^{\text {a }}$ T., RMS 21786/MT, Rel. Castro Meira, j. 27.03.2007, DJ 12.04.2007, p. 258).

${ }_{93}$ Acórdão: "O mandato de segurança já foi admitido pelo STJ contra decisão proferida pelo relator, nas hipóteses dos incisos II e III do artigo 527 do Código de Processo Civil.” Nesse sentido: STJ, 4. ${ }^{\text {a T., REsp }}$ 793.430/SC, Rel. Min. Cesar Asfor Rocha, j. 17.10.2006, DJ 11.10.2006, p. 375.

${ }^{94}$ RODRIGUES, Walter Piva. O princípio da colegialidade das decisões nos tribunais. Revista Dialética de Direito Processual. São Paulo, p. 177, abr. 2003.
} 
várias questões caibam diversos recursos, ou seja, cada um contra uma parte substancial e independente da decisão, sem que haja afronta ao princípio da unicidade recursal. ${ }^{95}$

A abrangência desse princípio é fixada levando-se em conta a natureza do ato judicial, o que se faz com a observância do estabelecido nos artigos 162 e 163 do Código de Processo Civil, para depois verificar qual o recurso adequado para aquele tipo de decisão judicial. A lei processual evidencia que o critério adotado foi o do conteúdo dessa decisão, não importando a forma que o juiz tenha dado ao ato, tampouco o nome que lhe atribuiu, restando ser estabelecido o que se entende por conteúdo do ato judicial recorrível, haja vista que a maior dificuldade surge na distinção entre decisão interlocutória e sentença. Além disso, várias questões podem ser decididas num único ato judicial complexo, ou seja, um ato composto por vários dispositivos, cada qual considerado per se como uma decisão, o que ocorre, por exemplo, quando o juiz decide várias questões quando da audiência preliminar e saneamento do processo, tais como: as preliminares de carência de ação, de incompetência absoluta, de coisa julgada etc., designando audiência de conciliação, instrução e julgamento. Nesse caso, a decisão proferida seria interlocutória, uma vez que não colocou fim ao processo, mas resolveu questões incidentes no seu curso. Em exemplo diverso, se o juiz, ao decidir essas mesmas questões, em vez de rejeitar a preliminar de carência de ação e designar audiência, acolher a preliminar, estaremos diante de uma sentença, pois colocou termo ao processo, sem que tenha decidido o mérito, conforme artigo 267, IV. $^{96}$

Quando houver decisões complexas compostas de capítulos distintos que possam ensejar o atendimento de requisitos de recursos diferentes, nem por isso haverá verdadeira exceção desse princípio como ocorre quando a Câmara, no julgamento da apelação, decide reformar a sentença de mérito por unanimidade quanto a uma parte da matéria impugnada, e, por simples maioria, quanto à outra parte. Nesse exemplo, o capítulo julgado por unanimidade ensejará recurso especial e/ou extraordinário, e serão cabíveis embargos

\footnotetext{
${ }^{95}$ PINTO, 2004. p. 88. No mesmo sentido, Cassio Scarpinela Bueno: "Isto não significa dizer, contudo, que, para diferentes capítulos de uma mesma decisão, situação da qual é exemplo clássico o art. 498. Também não agride o princípio aqui tratado quando uma mesma decisão aceita sucessivamente mais de um recurso, consoante sejam os vícios por ela apresentados e a vontade de o recorrente eliminá-los, como se dá, por exemplo, com a apresentação de embargos declaratórios para esclarecer obscuridade constante de sentença e, com a sua rejeição, a interposição de apelação contra a mesma sentença, visando a sua reforma” (2010, p. 49).

${ }^{96}$ NERY JR., 2014. item 2.5, p. 128-129.
} 
divergentes quanto ao capítulo julgado por maioria de votos, pois cada capítulo é considerado uma decisão per se. ${ }^{97}$

Nas palavras de Cândido Rangel Dinamarco, referindo-se aos embargos infringentes, o artigo 530 do Código de Processo Civil limita a devolução ao estabelecer que, "se o desacordo for parcial, os embargos serão restritos à matéria objeto da divergência”, ou seja, os embargos abrangerão somente os capítulos que comportem tal recurso. ${ }^{98}$ Portanto, quando uma decisão formalmente única seja dividida materialmente em vários capítulos autônomos, como é o caso do acórdão que, ao resolver duas ou mais questões, soluciona de forma unânime em relação a uma ou algumas questões, e de forma majoritária quanto às demais. Nessa situação, contra a decisão do capítulo majoritário, admitem-se embargos infringentes conforme artigo 530 do Código de Processo Civil e, quanto aos capítulos cuja decisão foi unânime, caberá recurso especial e/ou extraordinário, conforme o caso, na conformidade do artigo 498 do mesmo diploma legal. ${ }^{99}$

Assim, o princípio da unicorribilidade significa que para cada decisão somente há de se interpor um recurso, e não mais de um, se a decisão for cindível e, na realidade, substancialmente, forem duas ou mais decisões, para cada qual caberá o recurso respectivo. $^{100}$

O princípio da unicorribilidade não admite a interposição de dois recursos iguais, sucessivamente, contra a mesma decisão, ${ }^{101}$ tampouco se for interposto recurso errôneo, não se admite que a parte posteriormente efetue a substituição do recurso ${ }^{102}$ interposto erroneamente pelo recurso correto. ${ }^{103}$

No entanto, poderá ocorrer a flexibilização do princípio da unicorribilidade que se justifica quando uma mesma decisão exige a interposição de mais de um recurso

\footnotetext{
${ }^{97}$ BARBOSA MOREIRA, 2010. item 141, p. 249.

98 DINAMARCO, Cândido Rangel. Capítulos de sentença. 4. ed. São Paulo: Malheiros, 2009c. p. 107.

${ }^{99}$ ASSIS, 2008. p. 86.

${ }^{100}$ ARRUDA ALVIM, José Manuel. Anotações sobre a teoria geral dos recursos. In: NERY JR., Nelson; WAMBIER, Teresa Arruda Alvim (Coord.). Aspectos polêmicos e atuais dos recursos cíveis de acordo com a Lei 9.756/98. São Paulo: RT, 1999. p. 56.

${ }^{101}$ Nesse sentido: "Revela-se defeso a interposição simultânea de dois agravos regimentais contra o mesmo ato judicial ante o princípio da unicorribilidade recursal” (STJ, 4. ${ }^{\text {a }}$ T., AgRg no REsp 1080056/RS 2008/0166007-1, Min. Luis Felipe Salomão, DJe 30.08.2011).

${ }^{102}$ Nesse sentido: “A oposição de embargos infringentes, não conhecidos, porque a decisão de primeiro grau fora confirmada pelo acórdão, e posterior interposição de recurso especial, revela a ocorrência de preclusão consumativa, bem como a ofensa ao princípio da unirrecorribilidade. 2. Saliente-se que, protocolado o recurso incorretamente, não é possível à parte, posteriormente, apresentar o recurso cabível” (STJ, 2. ${ }^{a}$ T., REsp 981591/RS, 2007/0200261-2, Rel. Humberto Martins, j. 25.03.2008, DJe 03.04.2008).

${ }^{103}$ MEDINA et WAMBIER, 2011, p. 64.
} 
concomitantemente, com base em fundamentos diversos, por exemplo, quando a decisão recorrida tiver, ao mesmo tempo, “questão federal” e "questão constitucional” a ensejar a propositura simultânea de "recurso especial” e "recurso extraordinário”. 104

\subsection{Princípio da proibição da reformatio in pejus}

No Brasil, inexiste norma que proíba expressamente a reformatio in pejus, porém sua proibição emerge da análise sistemática de nossa legislação, como salienta Nelson Nery Junior: “mais precisamente da conjugação do princípio dispositivo, da sucumbência como requisito de admissibilidade e, finalmente, do efeito devolutivo do recurso". ${ }^{105}$

No Uruguai, demonstra Eduardo J. Couture que o princípio da reformatio in pejus consiste na proibição ao juiz de segundo grau piorar a situação do recorrente, nos casos em que não houve interposição de recurso por seu adversário. Salienta que o princípio da reformatio in pejus, de certo modo, é um princípio negativo: “consiste fundamentalmente em uma proibição. Não é possível reformar a sentença apelada em prejuízo do único apelante". 106

Um dos requisitos de admissibilidade dos recursos é o interesse na obtenção de uma posição mais favorável, razão da vedação ao órgão ad quem em apreciar o mérito do recurso se o apelante, por exemplo, formular pedido que agrave a sua situação, dado que o recurso seria inadmissível. Assim, a pretensão recursal deverá ser deduzida de modo a trazer algum benefício ao recorrente, sem o qual o recurso não será admissível.

Ao interpor o recurso, o recorrente fixa o objeto (o pedido) recursal, não sendo permitido ao órgão ad quem julgar o pedido recursal infra, extra ou ultra petita, pois deve prevalecer o princípio da congruência, seja no pedido originário formulado na causa, seja na esfera recursal. “A decisão que extravasar os contornos estabelecidos pelo pedido

\footnotetext{
${ }^{104}$ BUENO, 2010. p. 49; No mesmo sentido, Humberto Theodoro Júnior: "Na previsão de interposição simultânea de recurso extraordinário e recurso especial contra o mesmo acórdão (art. 541), há apenas uma aparente quebra do princípio da unirrecorribilidade, haja vista que cada um deles ataca partes distintas do decisório impugnado. Primeiro será julgado o especial e, somente quando o acórdão do STJ não se tornar prejudicial para o extraordinário, é que o último recurso subirá ao STF (art. 543, § 1. ${ }^{\circ}$ )” (Curso de direito processual civil. 50. ed. Rio de Janeiro: Forense, 2009. v. 1, p. 569).

${ }^{105}$ NERY JR., 2014. item 2.10, p. 185.

${ }^{106}$ COUTURE, Eduardo J. Fundamentos del derecho procesal civil. Buenos Aires: Depalma, 1958. p. 367368.
} 
recursal será inválida, assim como aquela que não respeitar os limites determinados na petição inicial.”107

Qualquer matéria que estiver excluída do âmbito da devolução recursal delimitada pelo recorrente não poderá ser modificada pelo órgão ad quem, nem para pior, nem para melhor, pois sobre tais capítulos ocorre a coisa julgada. ${ }^{108} \mathrm{Em}$ outras palavras, o tribunal somente pode apreciar pontos que lhe foram levados por iniciativa da parte recorrente, sendo-lhe defeso ampliar a extensão das razões recursais, é a máxima tantum devolutum quantum appellatum, consagrada no caput do artigo 515 do Código de Processo Civil: “A apelação devolverá ao tribunal o conhecimento da matéria impugnada”.

Doutrinariamente há uma questão polêmica quanto à cognição pelo juízo ad quem, sobre capítulos de sentença que versem a respeito de questão de ordem pública, independentemente da vontade das partes.

A primeira corrente perfilada por Antonio Carlos Marcato, Nelson Nery Junior, Cassio Scarpinella Bueno, José Miguel Garcia Medina e Tereza Arruda Alvim Wambier, Alcides de Mendonça Lima, Luiz Guilherme Marinoni e Sergio Cruz Arenhart defende que as questões de ordem pública são objetáveis a qualquer tempo, devendo o julgador atuar ex officio, ou seja, sem qualquer provocação, a cujo respeito não opera a preclusão. ${ }^{109}$

Em suma, para esses doutrinadores, quando o órgão ad quem examina ex officio questões de ordem pública, não há a reformatio in pejus, pois não atua o princípio do dispositivo tampouco há violação de qualquer fundamento que impeça a reforma para pior.

A segunda corrente liderada por Cândido Rangel Dinamarco, Humberto Theodoro Junior, José Carlos Barbosa Moreira e José Roberto dos Santos Bedaque considera que, se não houve recurso, a matéria, mesmo que seja de ordem pública, transitou em julgado e não poderá mais ser modificada.

\footnotetext{
${ }^{107}$ BARIONI, Rodrigo. A proibição da reformatio in peius e o $\S 3 .^{\circ}$ do art. 515 do CPC. In: NERY JR., Nelson; ALVIM WAMBIER, Teresa Arruda (Coord.). Aspectos polêmicos e atuais dos recursos cíveis. São Paulo: RT, 2005. v. 8, p. 698.

${ }_{108}$ APRIGLIANO, Ricardo de Carvalho. A apelação e seus efeitos. São Paulo: Atlas, 2007. p. 138.

109 MARCATO, Antonio Carlos. Preclusões: limitação ao contraditório? Revista de Processo. São Paulo, ano V, n. 17, p. 107, jan.-mar. 1980; NERY JR., 2014. item 2.11, p. 185; BUENO, 2010. p. 111; MEDINA et WAMBIER, 2011. p. 70; MENDONÇA LIMA, Alcides de. Introdução aos recursos cíveis. 2. ed. São Paulo: RT, 1976. p. 338; MARINONI, Luiz Guilherme; ARENHART, Sérgio Cruz. Processo de conhecimento. 7. ed. São Paulo: RT, 2008. p. 523; BARIONI, p. 700; CHEIM JORGE, 2009. p. 251.
} 
Esses doutrinadores defendem a estabilização da coisa julgada, pois, se a matéria transitou em julgado, não será mais permitido ulterior pronunciamento judicial sobre o assunto, para garantia da segurança jurídica. ${ }^{110}$

Quando ocorre sucumbência recíproca e tanto o autor quanto o réu recorrem, é possível que a situação dos recorrentes seja modificada para pior, mas isso não decorre do seu próprio recurso, e sim dos fundamentos recursais de seu adversário, não ocorrendo afronta ao princípio da proibição da reformatio in pejus.

No nosso sentir filiamo-nos à segunda corrente, a qual defende a estabilização da coisa julgada, em que, se um capítulo da decisão transitou em julgado, é defeso ao órgão ad quem reformá-lo ex officio, pois, se assim não for, irá gerar insegurança jurídica.

\subsection{Princípio da complementaridade}

Os recursos devem ser interpostos no prazo previsto pelo Código de Processo Civil, com as razões do inconformismo do recorrente, diferentemente do procedimento previsto no Código de Processo Penal.

Nelson Nery Junior afirma ocorrer preclusão consumativa, quando as razões recursais não acompanham a petição de interposição do recurso, ou seja, a parte não poderá mais praticar o ato de fundamentar o recurso, pois já terminou a oportunidade de fazê-lo.

No entanto, salienta o processualista que a parte poderá complementar o recurso interposto se, em razão do acolhimento de embargos de declaração, houver alteração ou integração da decisão. Não podendo o recorrente interpor novo recurso, a não ser que a decisão modificativa ou integrativa venha a alterar a natureza do pronunciamento judicial. ${ }^{111}$

${ }^{110}$ DINAMARCO, 2009c, p. 113-114. THEODORO JÚNIOR, 2009., p. 583-584; BARBOSA MOREIRA, 2010. item 196, p. 357-358; BARBOSA MOREIRA, José Carlos. Correlação entre pedido e a sentença. Revista de Processo. São Paulo, n. 83, p. 214-215, jul.-set. 1996; BEDAQUE, José Roberto dos Santos. Apelação: questões sobre admissibilidade e efeitos. In: NERY JR., Nelson; WAMBIER, Teresa Arruda Alvim (Coord.). Aspectos polêmicos e atuais dos recursos cíveis e de outros meios de impugnação a decisões judiciais. São Paulo: RT, 2003. v. 7, p. 464. No mesmo sentido: LOPES, Bruno Vasconcelos Carrilho. A reformatio in peius no direito processual civil. In: NERY JR., Nelson; WAMBIER, Teresa Arruda Alvim (Coord.). Aspectos polêmicos e atuais dos recursos cíveis. São Paulo: RT, 2005. v. 8, p. 49; MARCATO, Ana Cândida Menezes. Princípio do duplo grau de jurisdição e a reforma do Código de Processo Civil. 2006. Dissertação (Mestrado) - USP, São Paulo; BONICIO, Marcelo José Magalhães. Capítulos de sentença e efeitos dos recursos. São Paulo, RCS Editora, 2006. p. 165.

${ }^{111}$ NERY JR., 2014. item 2.10, p. 184. 
Se o julgamento dos embargos de declaração não alterar o provimento desfavorável ao recorrente, este não poderá efetuar qualquer outra manifestação, pois já recorreu dentro do prazo.

\subsection{Princípio da consumação}

Os recursos somente podem ser propostos na forma e no tempo previstos no nosso Código de Processo Civil. Se o recurso não for interposto na oportunidade prevista na lei, ocorrerá a preclusão.

A interposição de apelo parcial significa aquiescência com a parte remanescente da sentença, coibindo a interposição de outra apelação pelo mesmo recorrente. Esse princípio também subsidia a impossibilidade de a parte realizar o preparo no dia seguinte à sua interposição. $^{112}$

Se o recurso pode ser proposto de duas maneiras e o recorrente optou por uma delas, em obediência ao princípio da consumação lhe é defeso escolher a outra via para impugnar o mesmo pronunciamento judicial, visto que já exerceu o seu direito de recorrer anteriormente. Tal hipótese ocorre quando o recorrente, diante de uma decisão interlocutória, por exemplo, opta por um dos caminhos que o código lhe propicia. Ao escolher a forma de interposição do recurso de agravo, retido nos autos ou por instrumento, não poderá fazer uso da outra modalidade para atacar a mesma decisão interlocutória, mesmo que a segunda interposição tenha objetivo diverso do primeiro recurso interposto, isso em virtude do princípio da consumação. ${ }^{113}$

Também o recurso adesivo segue a mesma sistemática, e é preciso que aquele que pretende recorrer pela via adesiva não o tenha feito pela via principal, uma vez que a

\footnotetext{
112 ASSIS, 2008. p. 103. Nesse sentido Nicola Balzano esclarece: "l’impugnazione parziale importa acquiescenza alle parti della sentenza non impugnate” (Acquiescenza, parti di sentenza e questioni relevabili d’ufficio. Rivista di Diritto Processuale. Padova, v. 6, parte II, p. 217-218, 1951).

113 NERY JR., 2014. item 2.12, p. 192-193. Emanuele Ruggeri informa que, segundo o princípio da consumação, "una volta che l'impugnazione sia stata proposta - e per qualsiasi motivo il procedimento non giunga alla sua definizione, cioè alla decisione sulla rescissione o sulla riforma della sentenza censurata essa non può essere nuovamente inoltrata” (Il principio di consumazione dell'impugnazione: origine ed applicazioni. Rivista di Diritto Processuale. Padova, anno LXIII, Seconda Serie, n. 4, p. 1010, 2008).
} 
ausência de recurso independente por aquele que pretenda recorrer adesivamente é requisito de admissibilidade desse recurso. ${ }^{114}$

Em outras palavras, se uma das partes estiver inclinada a se conformar com a decisão, desde que o seu adversário também o faça, poderá aguardar tranquilamente o decurso do prazo comum. Se o prazo findar sem que a outra parte tenha recorrido, ocorrerá o trânsito em julgado da decisão, que ficará imune a qualquer modificação. No entanto, se a outra parte interpuser recurso, abre-se novamente ao litigante que ficou inerte a possibilidade de obter do órgão ad quem pronunciamento que melhore a sua situação. Desse modo, evita-se a interposição precipitada do recurso pela parte parcialmente vencida, em razão da certeza de que poderá recorrer adesivamente. ${ }^{115}$ No entanto, pelo princípio da consumação, para que a parte possa recorrer adesivamente é necessário que não tenha previamente interposto recurso independentemente.

\subsection{Princípio da voluntariedade}

Sob o aspecto do conteúdo, o recurso tem dois elementos distintos que são compostos do elemento volitivo, ou seja, a declaração expressa sobre a insatisfação com a decisão proferida e as razões dessa insatisfação. ${ }^{116}$

O interesse em recorrer deve ser daquele sucumbente que quer melhorar a sua situação, que tenciona encontrar no recurso uma forma de se tornar vencedor, seja totalmente ou em parte.

A vontade do recorrente, ao interpor o recurso, é manifestada nesse princípio, pois somente aquele que sucumbe, seja total ou parcialmente, terá interesse em recorrer e fará uso do princípio da voluntariedade, manifestando o elemento volitivo, declarando expressamente a sua insatisfação e explicando as suas razões de recorrer.

O juiz não pode recorrer de ofício, ou seja, não pode interpor recurso pela parte, mesmo que se trate de incapaz ou hipossuficiente. A vontade de recorrer deve ser

\footnotetext{
${ }^{114}$ NERY JR., 2014. item 2.12, p. 194. No mesmo sentido: BARBOSA MOREIRA, 2010. item 173, p. 317.

${ }^{115}$ BARBOSA MOREIRA, 2010. item 169, p. 309 e item 173, p. 317.

${ }^{116}$ NERY JR., 2014. item 2.8, p. 181. No mesmo sentido: CHEIM JORGE, 2009. item 10.2.1, p. 205.
} 
claramente manifestada por quem tem interesse na reforma ou invalidação da decisão proferida. $^{117}$

A manifestação inequívoca da vontade do recorrente é elemento essencial para a admissibilidade e a existência do recurso, razão pela qual a remessa obrigatória prevista no artigo 475, caput, do Código de Processo Civil não pode ser considerada recurso ${ }^{118}$ por lhe faltarem ambos os elementos: o volitivo e as razões de recorrer.

\subsection{Princípio da dialeticidade}

Segundo esse princípio, o recurso deve ser dialético, isto é, discursivo. O recorrente deverá explicar o porquê do pedido de novo exame da decisão, pois somente assim o recorrido poderá apresentar as suas contrarrazões, formando o contraditório recursal. ${ }^{119}$

O recurso se assemelha à petição inicial pois deve conter as razões de fato e de direito em que se baseia o inconformismo do recorrente, acompanhada do pedido de nova decisão. Se o recorrente não motivar o seu recurso, poderá ser causa de inépcia. O Código de Processo Civil prevê a exigência de motivação para todos os recursos como se constata no artigo 514, II e III, para o recurso de apelação; artigos 524 e 525 para o recurso de agravo; artigo 523, § 3. ${ }^{\circ}$, quanto ao agravo retido; artigo 536 para os embargos de declaração; artigo 540, quanto ao recurso ordinário; artigo 541, quanto aos recursos especial e extraordinário. ${ }^{120}$

Em outras palavras, as razões do recurso devem demonstrar a indicação dos errores in procedendo, ou in iudicando que na visão do recorrente viciam a sentença, bem como a exposição de motivos que deverão ser considerados na revisão do julgado.

\footnotetext{
${ }^{117}$ NERY JR., 2014. p. 181.

${ }^{118}$ Nesse sentido, Flávio Cheim Jorge discorre que: "Encartando-se a sentença nas previsões do art. 475, os autos serão encaminhados ao tribunal para o reexame da mesma, independentemente de qualquer manifestação da parte prejudicada” (2009. item 10.2.1, p. 206). Dando interpretação diversa, Araken de Assis entende que o reexame necessário ou remessa oficial (art. 475 do CPC) é exceção ao princípio da voluntariedade (2008. p. 98).

${ }^{119}$ NERY JR., 2014. item 2,7, p. 179.

${ }^{120}$ Ibidem, item 2.7, p. 179. Nesse sentido, Salvatore Satta leciona que "l'apello è dato contro l'ingiustizia della sentenza, è rimessa alla parte la determinazione dei fatti nei quali l'ingiustizia stessa si concreta: questo è appunto la motivazione dell'ingiustizia; e di qui dipendono due conseguenze in apparenza contraddittorie, da in lato l'esigenza assoluta della motivazione, perché essa è inseparabile dalla postulazione dell'ingiustizia, anzi è la forma necessaria di questa postulazione (um atto di appelo nel quale si dicesse soltanto che la sentenza è ingiusta sarebbe privo di ogni valore), dall'altro, l'elasticità della motivazione, che, appunto perché tale, non ha carattere formale, ma investe la sentenza nel suo complesso (Commentario al codice di procedura civile. Milano: Villardi, 1966, p. 117-118).
} 
A motivação do recurso delimita a matéria impugnada, sendo essencial a predeterminação da extensão e profundidade do efeito devolutivo, inexistindo forma rígida à motivação, sendo necessário que haja simetria entre o decidido e o alegado no recurso. Em outras palavras, a motivação deve ser concomitantemente específica, pertinente e atual. $^{121}$

Para que o juízo ad quem possa julgar o mérito do recurso, as razões recursais se tornam elemento indispensável, uma vez que o julgador irá confrontá-las com os motivos da decisão recorrida. A falta das razões recursais acarretará o não conhecimento do recurso, uma vez que este visa, precipuamente anular ou modificar a decisão considerada injusta pelo recorrente. ${ }^{122}$

\subsection{Princípio da irrecorribilidade em separado das interlocutórias}

Esse princípio significa que as decisões interlocutórias não são impugnáveis de maneira a paralisar todo o curso do procedimento, ou seja, as impugnações são realizadas de maneira racional, sem que haja a suspensão do processo. ${ }^{123}$

Com a adoção desse princípio pretende-se evitar que se confira efeito suspensivo ao recurso de agravo de instrumento, o qual é recebido somente no efeito devolutivo. ${ }^{124}$

A expressão “em separado” significa que o recurso é interposto diretamente no tribunal ad quem por instrumento, permanecendo os autos do processo no juízo de origem sem prejudicar o andamento processual.

Excepcionalmente, é possível conferir efeito suspensivo a recurso, na conformidade com o artigo 558 do Código de Processo Civil

\subsection{Princípio da fungibilidade recursal}

\footnotetext{
${ }^{121}$ ASSIS, 2008. p. 98.

${ }^{122}$ NERY JR., 2014. item 2.7, p. 179-180.

${ }^{123}$ Ibidem, item 2.9, p. 182. No mesmo sentido: ASSIS, 2008. p. 100.

${ }^{124}$ Nos dizeres de Nelson Nery Jr., o verdadeiro sentido do princípio da irrecorribilidade em separado das interlocutórias é coibir “apelações” contra decisões proferidas no curso do processo (2014. item 2.9, p. 182).
} 
Como já vimos, os recursos cabíveis em nosso ordenamento recursal estão previstos no artigo 496 do Código de Processo Civil, e, em várias ocasiões, ocorrem dúvidas na designação de certos atos decisórios.

A partir da Lei n. ${ }^{0} 11.232 / 2005$, a sentença não é mais conceituada como o ato que põe fim ao processo. O $\S 1 .^{\circ}$ do artigo 162 do Código de Processo Civil passou a dispor que “a sentença é o ato do juiz que implica algumas das situações previstas nos artigos 267 e 269 desta Lei”. O critério para a distinção entre sentença e decisão interlocutória passou a ser feito pelo conteúdo, ou seja, pela essência ou substância de cada ato. ${ }^{125}$

Em muitas ocasiões surgem dúvidas quanto à interpretação do conteúdo de atos decisórios, se é sentença ou decisão interlocutória, se o recurso cabível é apelação ou agravo de instrumento, e, para que não haja prejuízo para a parte interessada, pode-se aplicar o princípio da fungibilidade.

Nos dizeres de Tereza Arruda Alvim Wambier, identificam-se no sistema “zonas de penumbra”, ou seja, situações em face das quais se apresenta mais de uma solução possível, legitimada por parte da jurisprudência, pela doutrina e ainda pela própria lei. Essas zonas de penumbra se manifestam quando se admite, no sistema, mais de um caminho para se chegar ao mesmo lugar. No seu entender, quando houver uma zona de penumbra, deve-se optar pela resposta que privilegie os valores fundamentais, devendo incidir o princípio da fungibilidade. ${ }^{126}$

Paulo Henrique dos Santos Lucon, ao discorrer sobre esse princípio, menciona que o objetivo final é levar ao jurisdicionado a justiça, e não evitar o conhecimento dos recursos, que a forma não pode jamais prevalecer sobre a substância. ${ }^{127}$

O princípio da fungibilidade é extremamente importante no contexto deste estudo por tratar dos aspectos formais dos recursos, deriva diretamente do princípio da instrumentalidade das formas e demonstra a flexibilidade na admissibilidade dos recursos.

\footnotetext{
${ }^{125}$ LUCON, Paulo Henrique dos Santos. Recurso de agravo. In: NERY JR., Nelson; WAMBIER, Tereza Arruda Alvim (Coord.). Aspectos polêmicos e atuais dos recursos cíveis e assuntos afins. São Paulo: RT, 2007. v. 11, p. 308.

${ }^{126}$ WAMBIER, Tereza Arruda Alvim. O princípio da fungibilidade sob a ótica da função instrumental do processo. In: — Paulo: RT, 2005a. v. 8, p. 740.

${ }^{127}$ LUCON, 2007, p. 309.
} 
O sistema vigente, em várias situações, não tem a clareza pretendida no tocante à exata tipificação de quais recursos caberiam em determinados casos, e, em razão disso, fica impedida a identificação inequívoca do recurso adequado. É certo que doutrinadores e magistrados debatem-se, em muitos aspectos, em opiniões e decisões de uma forma e de outra diferentes a respeito de uma mesma hipótese, quando se torna necessária a aplicação do princípio da fungibilidade recursal. ${ }^{128}$

Para Nelson Nery Junior, a fungibilidade, como o próprio nome indica, significa troca, substituição, e o que ora se estuda é saber se é possível a substituição de recurso interposto inadequadamente por outro que seria o correto para impugnar determinada decisão judicial, visto que, na prática, há muitas dúvidas a respeito da adequação recursal em nosso sistema processual, ora derivadas das imperfeições e impropriedades terminológicas existentes no próprio código, ora oriundas de divergências doutrinárias e jurisprudenciais. $^{129}$

No Código de Processo Civil de 1939, o princípio da fungibilidade vinha expressamente consagrado no artigo 810 que prescrevia: “Art. 810. Salvo a hipótese de má-fé ou erro grosseiro, a parte não será prejudicada pela interposição de um recurso por outro, devendo os autos ser enviados à Câmara, ou Turma, a quem competir o julgamento”.

Já o Código de Processo Civil atual não contempla dispositivo que admita expressamente a possibilidade de aplicação da fungibilidade recursal e, tão logo entrou em vigor, pensava-se que pela simplicidade do sistema de recursos, em que da sentença cabe recurso de apelação e das decisões interlocutórias cabe recurso de agravo e da irrecorribilidade dos despachos, seria desnecessária a admissão da existência de aplicação do princípio da fungibilidade recursal.

No entanto, posteriormente, constatou-se que havia casos em que tanto a doutrina quanto a jurisprudência tinham dúvidas sobre o recurso a ser interposto, constatando-se, assim, a necessidade da aplicação do princípio da fungibilidade recursal.

\footnotetext{
${ }^{128}$ ARRUDA ALVIM, 1999. p. 58. O autor salienta: “Às vezes, depois de um determinado período, desaparece a dúvida objetiva, com a consolidação de um dos entendimentos e abandono de outro, que com esse colidia. O que se quer dizer é que, em regra, a premissa maior, que é a lei ou o sistema, são claros a respeito da indicação de qual é o recurso cabível. Mas, desde que não haja essa clareza, objetivamente havido o texto ou textos legais como não claros, é certo que não existe nitidez na premissa maior do silogismo, isto é, a indicação indiscutível de qual o recurso cabível. A fungibilidade se insere, exatamente, para evitar dano decorrente da ausência de clareza, legal ou sistemática".

${ }^{129}$ NERY JR., 2014. item 2.6, p. 148.
} 
Portanto, sobrevive o aludido princípio em sua plenitude, permitindo consequentemente o conhecimento do recurso impróprio em lugar do próprio (agravo de instrumento em lugar de apelação e vice-versa), ou melhor, o aproveitamento do primeiro como se fora o segundo, desde que satisfeitos três requisitos básicos: a) a interposição do recurso inadequado no prazo do recurso adequado, respeitados os demais requisitos normalmente exigíveis para a iniciativa recursal; b) inexistência de erro grosseiro ou de má-fé; c) existência de dúvida objetiva. ${ }^{130}$

O escopo do princípio da fungibilidade é estabelecer mecanismos capazes de contornar o problema do recurso interposto inadequadamente, sem que o recorrente fique prejudicado. De qualquer forma, há hipóteses em que se torna difícil aferir qual o recurso cabível, levando-se em conta a natureza da decisão judicial que se pretende impugnar. ${ }^{131}$ Somente para essas hipóteses é que se pode aplicar o princípio da fungibilidade, a fim de que a parte não fique prejudicada e responsabilizada por algo a que não deu causa, ou seja: a dúvida sobre a interposição do recurso correto.

Flávio Cheim Jorge aponta que essa possibilidade de utilização do princípio da fungibilidade tem duas causas. Em primeiro lugar, está ligada à circunstância de se evitar o formalismo excessivo ao se admitir um recurso; em segundo lugar, na circunstância de existir um erro do sistema quanto ao recurso cabível relativamente à determinada decisão e, nesses casos, admite-se a fungibilidade recursal para não prejudicar o recorrente. ${ }^{132}$

Somente para as hipóteses em que se torna difícil a aferição de qual é o recurso cabível em razão do pronunciamento judicial que se pretende impugnar não somente por impropriedades constantes do próprio código, mas também pela dúvida doutrinária ou jurisprudencial é que se pode utilizar o princípio da fungibilidade recursal, a fim de que a parte não fique responsabilizada e prejudicada por algo que não deu causa, ou seja, a dúvida quanto ao recurso cabível. ${ }^{133}$

Paulo Henrique dos Santos Lucon salienta que é preciso considerar que o objetivo final do princípio da fungibilidade é levar ao jurisdicionado a justiça, e não evitar o conhecimento dos recursos. $^{134}$

\footnotetext{
${ }^{130}$ Nesse sentido Milton Sanseverino entende que são dois os requisitos: o respeito ao prazo do recurso adequado e a inexistência de erro grosseiro (Fungibilidade dos recursos. Revista de Processo. São Paulo, ano VII, n. 25, p. 182-183, 1982).

${ }^{131}$ NERY JR., 2014. item 2.6, p. 148 e 153.

${ }^{132}$ CHEIM JORGE, 2009, p. 257.

${ }^{133}$ NERY JR., 2014. item 2.6.2, p. 153.

${ }^{134}$ LUCON, 2007, p. 309.
} 
Para a efetiva aplicação desse princípio, é necessária a constatação de: a) dúvida objetiva sobre qual recurso é cabível; b) inexistência de erro grosseiro; e c) que o prazo recursal seja respeitado.

\subsubsection{Existência de dúvida objetiva}

Salienta Nelson Nery Junior que o primeiro requisito desse princípio é a existência de dúvida objetiva sobre qual é o recurso correto a ser interposto, ainda que dada a simplicidade do nosso sistema recursal, no qual o Código de Processo Civil define os atos recorríveis, conforme inteligência do artigo 162, como também estabelece correlação entre os atos e o recurso cabível (artigos 504, 513 e 522), há hipóteses em que o recorrente se encontra com um dilema, não sabendo exatamente qual recurso deve interpor. ${ }^{135}$

No entendimento de Maria Berenice Dias, partindo-se da premissa de que não serve o rótulo legal para identificar o que é sentença e o que é decisão interlocutória, com o objetivo de definir, com a necessária certeza, qual o recurso cabível, se apelação ou agravo de instrumento, afirma que é necessária a busca de outros subsídios para a escolha da hipótese correta, e utiliza o critério topológico mencionado por José Carlos Barbosa Moreira que, referindo-se ao procedimento de primeiro grau, define sentença como a “decisão que põe termo ao processo”, e decisão interlocutória como aquela "que é proferida no curso do processo”. ${ }^{136}$

Cabe aqui a observação de que, na Exposição de Motivos do Código de Processo Civil de 1973, a opção do legislador de estabelecer a relação da sentença com o término do processo (atualmente fase procedimental) repercute diretamente no recurso a ser interposto contra ela. Estando a apelação nos mesmos autos, somente deve ser proposta contra decisões que encerram o procedimento destinado àquela fase, pois, se o processo prossegue no primeiro grau, não há condições de o tribunal julgar o recurso. De outro lado, as decisões interlocutórias são pronunciamentos judiciais proferidos incidentalmente no

\footnotetext{
${ }^{135}$ NERY JR., 2014. p. 153.

136 DIAS, Maria Berenice. Apelação versus agravo. In: NERY JR., Nelson; WAMBIER, Teresa Arruda Alvim (Coord.). Aspectos polêmicos e atuais dos recursos cíveis e de outros meios de impugnação às decisões judiciais. São Paulo: RT, 2005. v. 8, p. 442-443.
} 
processo, de natureza decisória, mas não propiciam o término da fase de cognição ou de execução. $^{137}$

Em várias situações, é difícil a identificação da natureza da decisão, quando ocorre a dúvida objetiva que se consubstancia na existência, na doutrina ou na jurisprudência, de controvérsia quanto à identificação do recurso adequado para atacar determinada decisão. Essa dúvida pode advir: a) da própria lei codificada que pode designar, de forma obscura ou impropriamente, uma decisão interlocutória como sentença ou vice-versa; b) quando existir divergência da classificação de determinados atos judiciais e, consequentemente, quanto à adequação do respectivo recurso para atacá-los; c) o juiz profere um pronunciamento no lugar de outro.

Em outras palavras, essa dúvida pode surgir de três formas: 1) quando o próprio código nomeia uma decisão interlocutória de sentença ou vice-versa; 2) quando ocorre divergência de classificação de determinados atos judiciais na doutrina, ou na jurisprudência, quanto à adequação do recurso correto a ser interposto; e 3) quando o juiz profere uma decisão no lugar de outra.

\subsubsection{Inexistência de erro grosseiro}

Outro requisito para a aplicação do princípio da fungibilidade é a inexistência do erro grosseiro, que se evidencia quando, por exemplo, a lei aponta textualmente qual tipo de recurso deve ser interposto, e o recorrente interpõe outro.

A “dúvida objetiva” e a "existência de erro grosseiro” são redutíveis ao que se denomina em fundada “dúvida” sobre o cabimento do recurso. ${ }^{138}$

Portanto, o erro grosseiro consiste na interposição de um recurso quando a lei prevê expressamente outro, ou seja, quando não há qualquer dúvida quanto ao recurso a ser interposto. A título de exemplo, o erro grosseiro se verifica quando o recorrente agrava da sentença que indefere a petição inicial, pois o artigo 296 textualmente expressa: "Se o autor apelar da sentença de indeferimento da petição inicial...”.

${ }^{137}$ CHEIM JORGE, Flávio; RODRIGUES, Marcelo Abelha. A sentença, a interlocutória e os recursos. In: MEDINA, José Miguel Garcia et al. (Coord.). Os poderes do juiz e o controle das decisões judiciais. Estudos em homenagem à Professora Teresa Arruda Alvim Wambier. São Paulo: RT, 2008. p. 711.

${ }_{138}$ BUENO, 2010. p. 53-54. 
Constitui outra hipótese de erro grosseiro quando a decisão é indubitavelmente interlocutória e o recorrente interpõe apelação, por exemplo, a decisão que julga a exceção de incompetência. Também verifica-se o erro grosseiro quando: a) a parte interpõe o recurso de agravo para impugnar sentença que indefere integralmente a petição inicial; b) quando interpõe agravo de decisão que julga a liquidação de sentença, uma vez que o artigo 520 estabelece que esse recurso seja recebido somente no efeito devolutivo, conforme seu inciso III que determina "julgar a liquidação de sentença”; c) quando a parte interpõe agravo de instrumento impugnando decisões proferidas em audiência do procedimento sumário, pois o inciso III do artigo 280 dispõe que o agravo seja retido etc. $^{139}$

Também constitui erro grosseiro quando a decisão é interlocutória e o interessado interpõe recurso de apelação, por exemplo, sobre a decisão que decreta a deserção do recurso, ou da decisão que decide sobre a impugnação do valor da causa.

\subsubsection{Respeito ao prazo recursal?}

Em razão de os prazos para a interposição dos recursos serem distintos, a jurisprudência dominante condiciona a aplicação do princípio da fungibilidade ao respeito, pelo recorrente, do prazo de interposição do recurso correto. ${ }^{140}$

\footnotetext{
${ }^{139}$ NERY JR., 2014. item 2.6.2.2, p. 167-168.

${ }^{140}$ Nesse sentido: “À luz dos princípios modernos do processo civil, dentre eles o da instrumentalidade e da fungibilidade recursal, que prestigiam a finalidade em detrimento da forma, admite-se a possibilidade de conversão dos recursos, desde que coexistam, simultaneamente, dúvida objetiva quanto ao recurso a ser interposto, inexistência de erro grosseiro, bem como a interposição de recurso dentro do prazo legal previsto para o recurso no qual pretende-se transformá-lo” (STJ, Recurso Especial 167123/SC, Rel. Min. Vicente Leal, j. 19.05.1998, v.u.).

“Ainda que pertinente a existência de dúvida quanto ao recurso a ser utilizado contra decisão que indefere parcialmente a inicial, na hipótese não se pode falar na aplicação do princípio da fungibilidade recursal, que exige o cumprimento de mais dois requisitos: ausência de erro grosseiro e que o recurso erroneamente interposto, tenha sido protocolado dentro do prazo do recurso que se quer seja admitido. Este último requisito não pode ser comprovado dos elementos trazidos aos autos, uma vez que o recorrente não cuidou de juntar a certidão da intimação da decisão atacada via tal recurso. Incidência 17.12.2004, REsp 117.429/MG, Rel. Min. Adhemar Maciel, DJ 09.06.1997; AgRg nos EREsp 588.006/SC, Rel. Min. Hamilton Carvalhido, DJ 13.12.2004. Agravo improvido” (STJ, AgRg no REsp 920389/RS, Rel. Min. Francisco Falcão, j. 17.05.2007, DJ 31.05.2007, p. 407).

“O princípio da fungibilidade recursal reclama, para sua aplicação, a inexistência de erro grosseiro, dúvida objetiva do recurso cabível, observando-se, ademais, a tempestividade do inconformismo restando inaplicável, in casu, tendo em vista que, acaso acolhida a apelação como recurso de agravo restaria o mesmo intempestivo (Precedentes: RCDESP na RCDESP no Ag 750223/MG, deste relator, DJ 18.12.2006; AgRg na MC 10533/MS, Rel. Min. Teori Albino Zavascki, DJ 17.10.2005; REsp 173975/PR, Rel. Min. Sálvio de
} 
Algumas decisões se distanciam da jurisprudência dominante, para a qual é irrelevante o prazo do recurso, desde que seja respeitado o prazo recursal do recurso que está sendo proposto. ${ }^{141}$

Doutrinariamente, há uma divisão no entendimento a respeito do prazo referente à interposição do recurso correto para a aplicabilidade do princípio da fungibilidade recursal.

Para parcela da doutrina, além da existência de dúvida objetiva e inexistência de erro grosseiro, o recurso "inadequado" deve ser interposto no prazo do recurso adequado. Nessa linha de raciocínio, José Frederico Marques leciona que "é imprescindível que o recurso que se lançou mão, erradamente, tenha sido interposto dentro do prazo fixado para a interposição do que seria cabível na espécie. Do contrário, não se conhece do recurso que por erro foi apresentado". ${ }^{142}$

A exigência pelos tribunais para que o recurso seja interposto no prazo adequado recebe críticas de outra corrente de entendimento, dentre os quais Nelson Nery Junior, ${ }^{143}$ para quem a regra da fungibilidade é ditada no interesse da parte, se presentes os pressupostos para a aferição da dúvida objetiva, ou, da inexistência de erro grosseiro, “o prazo se nos afigura absolutamente irrelevante. O recorrente deve, isto sim, respeitar o prazo do recurso efetivamente interposto, havido por ele como o correto para a espécie”.

No mesmo sentido, sustentam Teresa Arruda Alvim Wambier e José Miguel Garcia Medina, ${ }^{144}$ para quem a exigência de que se respeite o prazo de interposição do recurso

Figueiredo Teixeira, DJ 05.10.1998; REsp 86129/MG, Rel. Min. Barros Monteiro, DJ 24.09.2001)” (STJ, REsp 749184/MG, Rel. Min. Luiz Fux, j. 13.03.2007, DJ 02.04.2007, p. 236).

${ }^{141}$ Nesse sentido: "Recurso - Apelação - Interposição contra decisão proferida em incidente de impugnação à assistência judiciária - Cabimento de agravo de instrumento - Erro escusável, incidência do princípio da fungibilidade - Irrelevância do não atendimento do prazo menor - Recurso conhecido assistência judiciária Concessão - Garantia de acesso à justiça - Artigo 5. ${ }^{\circ}$, incisos LXXIV e XXXV, da Constituição Federal Recurso não provido” (TACSP, 22. ' Câmara de Direito Privado, Apelação c/revisão 908202981.2005.8.26.0000, j. 31.01.2006, R. 24.04.2006).

${ }^{142}$ MARQUES, José Frederico. Instituições de direito processual civil. Campinas: Millennium, 2000. v. 4, p. 50.

${ }^{143}$ NERY JR., 2014. item 2.6.2.3, p. 173. No mesmo sentido, BUENO, 2010. p. 54, para quem: “Não há, no entanto, como acolher o entendimento, largamente predominante na jurisprudência e herdado do Código anterior, de que o recurso, para ser aceito, deve ser interposto, havendo dualidade de prazos, no menor, medida apta para afastar qualquer pecha de má-fé. É que não há meio-termo entre existir, ou não, fundada e justificada dúvida sobre o cabimento de um dado recurso de uma dada decisão. Ou há dúvida e, por isto, os recursos que a ensejam devem ser admitidos, como se fossem os corretos, ou, inversamente, não há dúvida e por este fundamento, bastante, o princípio não se aplica independentemente da disciplina reservada pelo sistema processual civil ao recurso tal qual interposto, a começar pelo seu prazo. Assim, não há como compactuar com a fungibilidade verdadeiramente híbrida, que dá fundamento ao cabimento do recurso em si mesmo considerado, mas não para o seu regime jurídico correlato”.

${ }^{144}$ MEDINA et WAMBIER, 2011. p. 68. 
adequado é injustificada, bem como, se fosse negado esse direito ao recorrente, ocorreria violação ao princípio do devido processo legal.

No nosso entender, o prazo para a interposição do recurso correto é irrelevante, pois, inexistindo erro grosseiro, que seria cometido pelo recorrente, a dúvida objetiva advém de circunstâncias alheias à sua vontade, ou seja, o recorrente em nada contribuiu para a existência da ocorrência da dúvida objetiva e seria injusto ser prejudicado com a não aceitação da fungibilidade em razão do prazo recursal. 


\section{JUÍZO DE ADMISSIBILIDADE E JUÍZO DE MÉRITO DOS RECURSOS}

Na esteira do que vem sendo debatido neste estudo, a legislação processual brasileira contempla instâncias decisórias, das quais duas têm caráter ordinário e duas, o caráter extraordinário.

As instâncias de caráter ordinário representam a concretização do direito do cidadão ao duplo grau de jurisdição, ou seja, o direito de ver a sua causa apreciada por um juiz singular (juiz de direito, juiz federal ou juiz do trabalho) e reexaminada por um colegiado (Tribunal de Justiça, Tribunal Regional Federal ou Tribunal Regional do Trabalho), tanto nos seus aspectos de direito como nos seus aspectos fáticos. ${ }^{145}$

As instâncias extraordinárias representam a necessidade de uniformização e garantia de respeito da Constituição e do direito federal, se referem ao direito do Estado Federado de buscar por uma uniformidade na aplicação e na interpretação de suas normas em todo o território nacional, quer se trate da própria Constituição Federal que tem como guardião máximo o Supremo Tribunal Federal, quer se trate de lei federal, cujos guardiões são o Superior Tribunal de Justiça e o Tribunal Superior do Trabalho. ${ }^{146}$

Quando a parte, inconformada com a decisão que lhe foi desfavorável em primeira instância, recorre a uma instância superior, o seu recurso passa primeiramente por uma avaliação de admissibilidade, e, se ultrapassada essa fase, será analisado o seu mérito; caso não ultrapasse a fase de admissibilidade, o recurso não terá o seu mérito conhecido.

\subsection{Diferenciação entre juízo de admissibilidade e juízo de mérito}

Para explicar a diferenciação entre juízo de admissibilidade e juízo de mérito, José Carlos Barbosa Moreira estabelece uma comparação entre a origem de uma demanda, que

\footnotetext{
${ }^{145}$ MARTINS FILHO, Ives Gandra. O critério de transcendência no recurso de revista. Disponível em: <www.agu.gov.br/ce/cenovo/revista>. Acesso em: 23 fev. 2014.

146 Idem, ibidem.
} 
nasce em virtude do ajuizamento de um pedido feito por iniciativa da parte, e, por analogia, assim como a instauração do processo tem por finalidade a apreciação do pedido pelo órgão judicial, a interposição do recurso visa um novo pronunciamento, quer do mesmo órgão, quer de outro. No primeiro caso, a provocação se fundamenta em fato exterior e anterior ao processo, enquanto o recurso tem origem processual e sua ratio essendi se encontra no próprio ato recorrido. ${ }^{147}$

Rodolfo de Camargo Mancuso sintetiza que, assim como o juiz, em um processo válido, revestido de seus pressupostos, em que foram preenchidas as condições da ação, tais como interesse processual, legitimidade para agir e possibilidade jurídica do pedido, pode prover sobre o mérito da lide, também os recursos apresentam uma similaridade com o binômio processo/ação, exigindo o implemento de alguns pressupostos que são comuns a todos os recursos, os quais são denominados “pressupostos recursais genéricos”. 148

Em outras palavras, sendo o recurso um prolongamento do direito de ação e do direito de defesa, há uma correlação entre as condições da ação e os requisitos de admissibilidade dos recursos. Na verdade, tudo se passa como se as condições da ação fossem transportadas para a fase recursal, ou seja, a analogia e o paralelismo existentes são verdadeiros, uma vez que na fase recursal têm-se os requisitos de admissibilidade dos recursos, ${ }^{149}$ apesar de saber que na ação os requisitos são verificados em relação a fatos exteriores e anteriores ao processo, e, nos recursos, os requisitos de admissibilidade são aferidos no próprio processo. ${ }^{150}$

Logo, pode-se afirmar que, enquanto o mérito da ação consiste no pedido formulado pelo autor na petição inicial, o mérito recursal corresponde ao pedido de reforma, de anulação e/ou de integração formulado pelo recorrente em relação à decisão recorrida. $^{151}$

\footnotetext{
${ }^{147}$ BARBOSA MOREIRA, José Carlos. O juízo de admissibilidade no sistema dos recursos cíveis. 1968. Tese (Livre-docência de direito judiciário civil) - Rio de Janeiro, p. 30.

${ }^{148}$ MANCUSO, Rodolfo de Camargo. Recurso extraordinário e recurso especial. São Paulo: RT, 2012. p. 222.

${ }^{149}$ Nesse sentido: CHEIM JORGE, Flávio. Requisitos de admissibilidade dos recursos entre a relativização e as restrições indevidas (jurisprudência defensiva). In: OLIVEIRA et al. (Coord.). Recursos e a duração razoável do processo. Brasília: Gazeta Jurídica, 2013. p. 176. Vicente Greco Filho ensina que: "os pressupostos dos recursos não são mais do que as condições da ação e os pressupostos processuais reexaminados em fase recursal e segundo as peculiaridades dessa etapa do processo" (Direito processual civil brasileiro. 20. ed. São Paulo: Saraiva, 2009. p. 303).

${ }^{150}$ BARBOSA MOREIRA, 1968, p. 26.

${ }^{151}$ PINTO, Nelson Luiz. Recurso especial para o Superior Tribunal de Justiça teoria geral e admissibilidade. São Paulo: Malheiros, 1992. p. 69.
} 
Discorre Cândido Rangel Dinamarco que em nosso direito toda interposição recursal tem o efeito direto e imediato de prevenir a preclusão temporal, a qual ocorrerá se nenhum recurso for interposto. Ao recorrer, a parte evita que o ato judicial recorrido adquira desde logo a firmeza e a imutabilidade, ou seja, impede que naquele momento ocorra a preclusão. Esse efeito integra o conceito desse remédio processual e está presente em todo e qualquer recurso. ${ }^{152}$

Quando uma sentença é objeto de recurso, obstam-se a coisa julgada formal e, se a sentença for de mérito, a coisa julgada material.

Com o intuito de assegurar que o pronunciamento tenha um conteúdo justo, a lei se preocupa em regular o modo pelo qual ele há de surgir, fazendo com que o mecanismo destinado a produzi-lo seja cercado por inúmeras cautelas, que se constituem de duas séries de normas: a primeira, relativa aos pressupostos processuais de existência e de validade do processo; a segunda, concernente às condições, sem as quais não se pode, legitimamente, exercer o direito de ação. As questões relativas a esses requisitos configuram-se como preliminares ao conhecimento do mérito, ou seja, elas constituem, no seu conjunto, o objeto de um juízo logicamente anterior àquele que incide sobre o pedido, que se denomina juízo de admissibilidade. Com referência ao recurso, a atividade cognitiva é feita em dois níveis distintos: um que apura a existência dos requisitos necessários para a apreciação da controvérsia e outro que analisa a controvérsia de fundo, coincidente ou não com a agitada na instância inferior. O primeiro nível logicamente precede o segundo, e sempre há a possibilidade de que o conhecimento do segundo se detenha no primeiro crivo. ${ }^{153} \mathrm{O}$ primeiro nível se denomina “juízo de admissibilidade” e o segundo, “juízo de mérito”.

Em outras palavras, todo recurso prolonga a relação jurídica processual e a solução do conflito, e, para autorizar a atividade adicional subsequente à sua interposição, a lei impõe uma série de requisitos específicos. Ao exame desse conjunto de condições, incumbido ao órgão judiciário, que é feita previamente ao julgamento do próprio conteúdo da impugnação, dá-se o nome de “juízo de admissibilidade”. Admissível o recurso, em razão do cumprimento das condições de admissibilidade, consubstanciados no atendimento dos requisitos específicos, diz-se que o recurso é conhecido ou a ele é negado seguimento.

\footnotetext{
152 DINAMARCO, Cândido Rangel. Os efeitos dos recursos. In: NERY JR., Nelson; WAMBIER, Teresa Arruda Alvim (Coord.). Aspectos polêmicos e atuais dos recursos cíveis. São Paulo: RT, 2002a, v. 5, p. 2627. Diverso é o entendimento de Nelson Nery Jr., o qual afirma que as interposições recursais têm somente o efeito de adiar, ou retardar a preclusão, não o de impedi-la (2014. item 3.1, p. 207).

153 BARBOSA MOREIRA, 1968, p. 30-32.
} 
No entanto, mesmo que seja admissível, nada assegura que a impugnação seja efetivamente provida, pois o acolhimento ou não das alegações do recorrente e a análise da existência ou inexistência de fundamento serão feitos em etapa ulterior, designada "juízo de mérito”. 154

Em suma, pode-se afirmar, conforme lições de Francesco Carnelutti, ${ }^{155}$ que, referente aos recursos, há dois juízos distintos: o “juízo de admissibilidade” e o "juízo de mérito”. Se concorrerem todos os pressupostos exigíveis para a emissão de um novo pronunciamento, o juízo de admissibilidade será positivo e o recurso ficará apto ao julgamento do mérito; se faltar um ou mais de um desses pressupostos, o juízo de admissibilidade será negativo e, nesse caso, o mérito do recurso não será analisado.

O juízo de admissibilidade se diferencia do juízo de mérito, uma vez que o primeiro visa tão somente o cabimento ou não do recurso, o seu conhecimento ou não, e o segundo diz respeito ao próprio conteúdo de fundo do recurso. A decisão sobre o juízo de admissibilidade do recurso será de conhecimento ou não de suas razões, enquanto o juízo de mérito será de provimento ou não do recurso. Quando o recurso não é conhecido, ou seja, quando é denegado o seu seguimento pelo juízo de admissibilidade, o órgão ad quem não menciona os fundamentos de fato e de direito nem o pedido de nova decisão, limita-se a dizer que o recurso é incabível. Se for dado seguimento ao recurso, ou seja, se o recurso for conhecido, o órgão ad quem, após fazer digressões e considerações sobre as razões recursais, aduzidas pelo recorrente e pelo recorrido, dará ou negará provimento ao recurso, ou seja, fará a apreciação do mérito recursal. ${ }^{156}$

O exame do mérito recursal somente pode ser feito após a análise da presença dos requisitos de admissibilidade, que funcionam como condição necessária ao julgamento do mérito do recurso interposto.

Essa constatação demonstra, semelhantemente às condições da ação, que o juízo de admissibilidade dos recursos é formado por questões prévias, uma vez que o pronunciamento de mérito somente ocorre após o prévio juízo de admissibilidade do

\footnotetext{
154 ASSIS, 2008. p. 116.

${ }^{155}$ CARNELUTTI, Francesco. Lezioni di diritto processuale civili. Padova: Cedam, 1925. v. 4, p. 187: "La ammissione del gravame consiste nell'acccertamento dei pressuposti, ai quali la legge subordina la possibilità di mutamento della decizione di primo grado”.

${ }^{156}$ NERY JR., Nelson. Fundamentos da apelação como requisito de admissibilidade. Revista de Processo. São Paulo, ano V, n. 18, p. 112, 1980.
} 
recurso. O juízo de admissibilidade antecede cronologicamente e torna ou não possível o exame de mérito. ${ }^{157}$

Essas questões prévias, que constituem o juízo de admissibilidade dos recursos, são todas aquelas que logicamente devem ser decididas antes de outras, por manterem entre si uma relação de dependência. ${ }^{158}$

Há duas espécies de questões prévias: as prejudiciais e as preliminares. As questões prejudiciais são aquelas cuja decisão dependa o teor ou o conteúdo da solução de outras, enquanto as preliminares limitam-se a tornar admissível ou não o julgamento da questão seguinte, sendo possível afirmar que o juízo de admissibilidade dos recursos é formado por questões prévias, da espécie preliminares. ${ }^{159}$

As questões de admissibilidade do recurso são preliminares de seu mérito, pois dizem respeito à possibilidade de conhecimento do recurso pelo órgão competente, em função das condições e dos pressupostos genéricos impostos pela lei, como a legitimidade e o interesse de recorrer, a tempestividade, a regularidade formal do recurso, o preparo etc., e dos pressupostos específicos (hipóteses de cabimento) de cada recurso em espécie. ${ }^{160}$

Diz-se na linguagem forense que há dois fenômenos quanto aos recursos: o primeiro assentado pelas expressões “conhecer” e "não conhecer”, utilizadas pelo "juízo de admissibilidade”; o segundo pelas expressões “dar provimento” ou "negar provimento”, que são utilizadas pelo "juízo de mérito”. 161

Em outros dizeres, quando o recurso é recebido e analisado sob a ótica do juízo de admissibilidade, é feita a análise dos pressupostos de sua interposição, e será afirmado se suas alegações serão “conhecidas” ou "não”; se "não for conhecido”, o recurso retornará à origem. Caso as questões (pressupostos de sua interposição) sejam analisadas e se

${ }^{157}$ CHEIM JORGE, 2013. p. 177.

${ }^{158}$ ALVIM, Thereza. Questões prévias e os limites objetivos da coisa julgada. São Paulo: RT, 1977. p. 1112. Enrico Redenti se manifesta no sentido de que "la materia del contendere nel merito si presenterà al giudice sotto l'aspetto di um unico problema da decidire. Di solito essa potrà e dovrà, anzi, essere scomposta per analisi in una serie di punti di questione, sui quali converrà che il giudice porti la sua attenzione in ordine successivo... Il che può riuscire talvolta logicamente e praticamente necessario, anche perché l' eventuale risoluzione negativa di un punto può precludere e rendere inutile l'esame e da decisione degli altri” (Diritto processuale civile. 4. ed. Milano: Giuffrè, 1997. v. 2, p. 23).

159 BARBOSA MOREIRA, 1968, p. 133; CHEIM JORGE, 2013. p. 178.

160 PINTO, 2004. p. 49. O autor salienta que "é evidente que no julgamento do recurso pode-se voltar a examinar, pela primeira vez, as questões preliminares ao mérito da ação, por se tratar de questões de ordem pública, nulidades absolutas, como as condições da ação e os pressupostos processuais. Isso é possível em razão da previsão expressa do art. 267, § 3. , do CPC, sendo este, então, o próprio mérito do recurso”.

161 NERY JR., 2014. item 3.4, p. 239. No mesmo sentido: BARBOSA MOREIRA, 1968, p. 33: “Nossa prática judiciária de há muito consagrou as expressões 'conhecer' ou 'não conhecer' do recurso, de um lado, e 'dar provimento' ou 'negar provimento', de outro”. 
encontrarem em ordem, o recurso será “conhecido” e passará, então, ao exame do mérito, em que serão verificadas as razões do recurso, para, assim, ser proferida a decisão pelo juízo de mérito, que acolherá (dará provimento), ou não acolherá (negará provimento), as razões do inconformismo daquele que recorreu.

Quando se fala em juízo de mérito, há dois sentidos diversos: um diz respeito à ação e outro ao recurso. O mérito da ação é a lide, o objeto litigioso; já o mérito do recurso pode, eventualmente, confundir-se com o mérito da causa. Uma questão como a legitimidade, por exemplo, que na ação encontra-se no terreno das preliminares, pode vir, na via recursal, constituir o próprio mérito. ${ }^{162}$

O juízo de admissibilidade é essencialmente declaratório, e o órgão judicial verifica se estão ou não satisfeitos os requisitos indispensáveis à legítima apreciação do mérito do recurso. A existência ou a inexistência desses requisitos são anteriores ao pronunciamento, que simplesmente o reconhece. ${ }^{163}$

É no juízo de admissibilidade que se resolvem as preliminares relativas ao seu cabimento, se o recorrente tem legitimidade para recorrer, se o recurso tem previsão legal, se está adequado à decisão atacada e se é tempestivo. Se o resultado for positivo, o órgão revisor “conhecerá as razões do recurso”. Caso contrário, “não conhecerá”, ou seja, o recurso será rejeitado, sem exame do pedido de novo julgamento da decisão impugnada. ${ }^{164}$

Segundo José Carlos Barbosa Moreira, do ponto de vista da política jurídica, o emprego do filtro do juízo negativo de admissibilidade se concretiza de dois modos: a) quando atribui-se ao juízo a quo a fiscalização para impedir, o quanto antes, o dispêndio vão de energias, como também o gasto injustificado de pecúnia com um recurso fadado a não dar fruto. Esse objetivo é alcançado quando o recorrente se conforma com a denegação do recurso; b) quando o órgão ad quem destaca um juiz que se incumbe de proceder desde logo a apuração dos requisitos, com competência para negar seguimento ao recurso, do que decorre a vantagem de diminuir a pauta do colegiado e propiciar mais rapidamente um desfecho. $^{165}$

\footnotetext{
${ }^{162}$ WAMBIER, Teresa Arruda Alvim. Os agravos no CPC brasileiro. 4. ed. São Paulo: RT, 2006. p. 151. ${ }^{163}$ BARBOSA MOREIRA, José Carlos. O novo processo civil brasileiro. 16. ed. Rio de Janeiro: Forense, 1994a, p. 141; Idem. Restrições ilegítimas ao conhecimento dos recursos. Temas de direito processual. Nona série. São Paulo: Saraiva, 2007b, p. 265.

${ }^{164}$ THEODORO JÚNIOR, 2009. item 526, p. 560.

${ }^{165}$ BARBOSA MOREIRA, 2007b, p. 269.
} 
Nos dizeres de Cândido Rangel Dinamarco, quando o juízo de admissibilidade da apelação, do recurso ordinário, do recurso extraordinário, do recurso especial é realizado pelo juízo a quo, progride-se na caminhada para o tribunal destinatário, iniciando-se com ônus do recorrido de responder ao recurso. Nesse momento já se configura o poder-dever do Poder Judiciário, de apreciar, em grau superior, o recurso interposto, embora ainda não esteja definido o dever de apreciação de seu mérito. ${ }^{166}$

Pode-se estabelecer uma correlação entre ação e recurso, assim como o exame das preliminares influi no julgamento ou não do mérito da ação, também, quanto ao recurso, do juízo de sua admissibilidade dependerá o julgamento ou não do mérito recursal.

\subsection{Da competência para decidir a respeito da admissibilidade dos recursos}

Em geral, o recurso é interposto perante o órgão que proferiu a decisão impugnada, constituindo exceção a interposição do recurso diante de órgão diverso, como ocorre no caso do agravo de instrumento contra as decisões de primeiro grau que é interposto diretamente no tribunal de acordo com o artigo 524 do Código de Processo Civil e dos recursos especial e extraordinário que devem ser propostos perante o presidente, ou vicepresidente do tribunal recorrido, conforme artigo 541 do Código de Processo Civil.

A primeira verificação dos requisitos de admissibilidade dos recursos sempre foi feita pelo magistrado a quem compete recebê-los, que considerando tais pressupostos, ou seja, tempestividade, interesse na revisão do decidido, preparo, adequação, regularidade da petição e, ainda, os pressupostos específicos de determinados pedidos, dará o juiz o seguimento ao recurso que, após o devido contraditório, remeterá ao julgamento do órgão colegiado competente. A segunda perquirição, sem prejuízo de eventual reexame da matéria pelo colegiado, é do relator. O colegiado, por sua vez, antes de examinar o mérito, pode e deve revisar as questões dos pressupostos, pois não está vinculado pelas decisões de admissibilidade feitas anteriormente. ${ }^{167}$

Na mesma linha de raciocínio, Nelson Nery Junior aduz que a competência para o juízo de admissibilidade dos recursos é do órgão ad quem, cabendo ao tribunal destinatário

\footnotetext{
${ }^{166}$ DINAMARCO, 2002a, p. 57-58.

167 CARNEIRO, Athos Gusmão. Poderes do relator e agravo interno - artigos 557, 544 e 545 do CPC. Revista Jurídica. Porto Alegre, ano 48, p. 7, ago. 2000.
} 
o exame definitivo sobre a admissibilidade do recurso. No entanto, em atendimento ao princípio da economia processual, o juízo a quo, num primeiro momento, decide provisoriamente sobre a admissibilidade do recurso. Essa decisão do juízo a quo poderá ser modificada pelo tribunal, a quem compete definitivamente proferir o juízo de admissibilidade recursal, pois o órgão ad quem não fica vinculado ao juízo de admissibilidade positivo proferido anteriormente pelo juízo de primeira instância. ${ }^{168}$

A verificação da admissibilidade do recurso feita pelo órgão perante o qual se interpõe o recurso concerne apenas aos requisitos apuráveis no momento da interposição, ou seja, aos requisitos que se aperfeiçoaram antes do recebimento do recurso, uma vez que escapam ao seu controle as causas supervenientes ao seu recebimento, por exemplo, a deserção. Sem prejuízo do artigo 518, § 2. ․ do Código de Processo Civil, se depois de admitido o recurso pelo juízo a quo vier a faltar algum requisito, mesmo antes da subida ao órgão ad quem, o juízo a quo não poderá mais lhe negar seguimento, dado que somente ao juízo superior competirá a declaração de inadmissibilidade, mesmo porque a questão da admissibilidade não deve nunca ser subtraída à apreciação do órgão ad quem. ${ }^{169}$

Portanto, a competência atribuída ao órgão que proferiu a decisão recorrida, perante o qual se interpõe o recurso para aferir-lhe a admissibilidade, não exclui obviamente a competência do órgão ad quem, concernente a esse ponto. O órgão ad quem pode e deve examinar, ou reexaminar, livremente a matéria do recurso, visto que o pronunciamento quanto à admissibilidade proferido pelo juízo a quo não gera preclusão, pois o recurso pode ser rejeitado como inadmissível pelo órgão perante o qual se interpõe, mas dessa decisão a lei faculta ao recorrente outro recurso, a ser julgado pelo juízo ad quem. ${ }^{170}$ Assim, se o recorrente interpõe recurso de apelação, cujo seguimento é denegado pelo juízo a quo, o recorrente poderá interpor recurso de agravo de instrumento a ser julgado pelo órgão ad quem, uma vez que é esse juízo quem tem a competência definitiva para o juízo de admissibilidade.

Na opinião de Athos Gusmão Carneiro, a competência do relator em âmbito monocrático, no que concerne à admissibilidade dos recursos, foi ampliada pela Lei n. ${ }^{\circ}$ 9.756/1998, pois ele não apenas “poderá”, mas “deverá” examinar preliminarmente se

\footnotetext{
${ }^{168}$ NERY JR., 2014. item 3.4, p. 241.

169 BARBOSA MOREIRA, 2010. item 146, p. 263-264; Idem. Juízo de admissibilidade e juízo de mérito no julgamento do recurso especial. Temas de direito processual. Quinta Série. São Paulo: Forense, 1994c, p. 133.

${ }^{170}$ BARBOSA MOREIRA, 2010. item 134, p. 264.
} 
concorrem os requisitos de admissibilidade de qualquer recurso. É evidente, todavia, que essa atribuição não abrange os embargos de declaração, pois estes devem ser apresentados em mesa na sessão subsequente, artigo 537, do Código de Processo Civil, e também não atinge os agravos internos, que são interpostos contra a decisão do próprio relator. ${ }^{171}$

\subsection{Efeitos do juízo de admissibilidade}

Como examinado ao tratarmos de competência, em geral, o juízo de admissibilidade dos recursos passa por um duplo controle: o primeiro realizado pelo órgão que proferiu a decisão que se impugna e outro pelo órgão ad quem.

O primeiro juízo de admissibilidade realizado pelo órgão que proferiu a decisão recorrida não é definitivo, visto que a competência final cabe ao órgão ad quem. Esse juízo examinará o recurso e poderá emitir um juízo positivo ou negativo de admissibilidade, e, seja qual for essa decisão, gerará efeitos.

Se esse primeiro exame de admissibilidade for positivo, apenas proporcionará oportunidade para que o recurso suba para o tribunal ad quem, competente para o julgamento do recurso.

Quando o recurso tiver efeito suspensivo, terá o efeito de prolongar o estado de ineficácia em que se encontra a decisão recorrida. ${ }^{172}$

No caso de o primeiro juízo de admissibilidade ser negativo, estará negando o envio do recurso ao órgão ad quem, o que impede desde logo o exame do mérito recursal. Além disso, possibilita a eficácia imediata da sentença recorrida, a qual poderá transitar em julgado ou se tornar preclusa (caso se trate de decisão interlocutória, impugnada por recurso de agravo de instrumento). ${ }^{173}$

Se o juízo de admissibilidade realizado na instância inferior for negativo, o ato judicial que assim decide cria para o recorrente mais um ônus que é o de interpor agravo de instrumento destinado a obter o seu trânsito. ${ }^{174}$ Nesse caso, o mérito desse agravo de

\footnotetext{
${ }^{171}$ CARNEIRO, 2000, p. 9.

${ }^{172}$ Nesse sentido, Nelson Luiz Pinto frisa que "não se fala, ainda, no efeito de possibilitar devolutividade das questões decididas ao órgão superior (efeito devolutivo dos recursos) porque o recurso está sujeito, ainda, ao juízo de admissibilidade do órgão julgador” (1992. p. 75).

173 Ibidem, p. 75-76.

${ }^{174}$ DINAMARCO, 2002a, p. 57-58.
} 
instrumento será exatamente a admissibilidade do primeiro recurso, que não será examinado, caso esse segundo recurso venha a ter juízo negativo de admissibilidade, haja vista que as mesmas regras de admissibilidade lhes são aplicáveis. ${ }^{175}$ No entanto, se esse segundo recurso tiver o juízo de admissibilidade positivo, o primeiro recurso será examinado pelo órgão superior que emitirá um novo juízo de admissibilidade.

Se, no recurso de apelação, o primeiro juízo de admissibilidade realizado pelo órgão que proferiu a decisão recorrida for negativo, o apelante poderá valer-se do ônus de recorrer dessa decisão que denegou o encaminhamento do recurso de apelação, interpondo recurso de agravo de instrumento (regra geral do artigo 522 do CPC) diretamente ao órgão ad quem. O mérito desse recurso de agravo de instrumento será a admissibilidade do recurso de apelação. O recurso de agravo também passará pelo crivo do juízo de admissibilidade, caso seja negativo, o recurso de apelação não terá o seu mérito examinado. Nesse caso, a decisão que negou seguimento ao recurso de agravo poderá ser recorrida em razão de tratar-se de decisão singular, cabendo o agravo interno previsto no $\S$ 1. ${ }^{\circ}$ do artigo 557 do CPC.

No entanto, se o juízo de admissibilidade for positivo, o órgão ad quem não só dará provimento ao recurso de agravo de instrumento, como analisará o mérito do recurso de apelação, dando ou negando-lhe provimento.

Em outros termos, o segundo juízo de admissibilidade feito pelo órgão julgador, ou seja, pelo órgão ad quem, por meio de decisão monocrática do relator, também pode ser positivo ou negativo, e é realizado quando o recurso é recebido após ter passado pelo juízo positivo de admissibilidade feito pelo órgão a quo, que proferiu a decisão recorrida, ou quando o primeiro juízo de admissibilidade foi negativo, mas o recorrente propôs recurso de agravo de instrumento, o qual teve o seu julgamento provido.

O juízo de admissibilidade feito pelo órgão ad quem, se positivo, tem o efeito de ensejar a passagem ao exame de mérito do recurso. Nessa hipótese, o órgão ad quem conhece o mérito do recurso, seja para dar-lhe, seja para negar-lhe provimento, conforme, a seu ver, tenha ou não razão o recorrente. ${ }^{176}$

\subsection{Requisitos de admissibilidade dos recursos em geral e sua importância}

\footnotetext{
${ }^{175}$ PINTO, 1992. p. 76.

${ }^{176}$ BARBOSA MOREIRA, 2010. item 134, p. 266.
} 
Os requisitos de admissibilidade dos recursos são os elementos integrantes do juízo de admissibilidade que condicionam ao exame da pretensão recursal. Portanto, o objeto do juízo de admissibilidade é formado pelos requisitos necessários para o conhecimento e julgamento do mérito dos recursos.

Segundo Flavio Cheim Jorge, esses elementos são denominados de requisitos para que não sejam confundidos com elementos integrantes do juízo de admissibilidade da demanda, ou seja, para que não sejam confundidos com as condições da ação e os pressupostos processuais. ${ }^{177}$

Com exceção do agravo de instrumento, o recurso é interposto no juízo a quo e o controle de admissibilidade é feito pelo próprio órgão que proferiu o pronunciamento recorrido. Também têm competência para o exame da admissibilidade o relator e o órgão ad quem, conforme artigos 531, 542, § 1. ${ }^{\circ}$, e 557 do Código de Processo Civil. Se no exame monocrático for detectada a ausência de um dos requisitos, ao recurso será negado seguimento. ${ }^{178}$

O fato de a presença dos requisitos de admissibilidade condicionar o exame do mérito recursal induz à reflexão sobre as consequências de seu não adequado preenchimento, dado que a não admissibilidade dos recursos impede que as partes intentem novamente, ou renovem, seu direito de ação e de defesa. ${ }^{179}$ É nesse sentido que a interpretação das regras processuais de admissibilidade recursal deve facilitar o acesso ao duplo exame, pois o escopo maior é a obtenção da adequada tutela jurisdicional, pela via estatal de solução das controvérsias. ${ }^{180}$

Na Itália, Federico Carpi discorre que a valoração de admissibilidadeinadmissibilidade do recurso deveria preceder qualquer outra pronúncia, mesmo que ordenatória. Salienta que a norma disciplina duas hipóteses: a) quando o provimento impugnado decidiu as questões de direito em conformidade com a jurisprudência da Corte e o exame dos motivos não oferece elementos para mudar a orientação, ou, quando os motivos não são suficientes para confirmar a orientação, ao qual não teve o provimento

\footnotetext{
${ }^{177}$ CHEIM JORGE, 2013. p. 179.

${ }^{178}$ BEDAQUE, 2003, p. 438.

${ }^{179}$ CHEIM JORGE, 2013, p. 181.

${ }^{180}$ BEDAQUE, 2003, p. 35; CHEIM JORGE, 2013. p. 181.
} 
impugnado; b) a inadmissibilidade deriva da manifestada falta de fundamento da censura relativa à violação dos princípios regulares do processo justo. ${ }^{181}$

José Carlos Barbosa Moreira qualifica os requisitos de admissibilidade dos recursos de intrínsecos e extrínsecos. São requisitos intrínsecos: a) cabimento - para que seja cabível o recurso, é preciso que o ato impugnado seja, em tese, suscetível de ataque por meio dele; b) legitimação para recorrer - autor, réu, qualquer litisconsorte, bem como o interveniente; c) interesse em recorrer - configura-se sempre que o recorrente possa esperar, em tese, do julgamento do recurso, situação mais vantajosa; d) inexistência de fato impeditivo e extintivo do ônus de recorrer. São requisitos extrínsecos: 1) tempestividade todo recurso deve ser proposto no prazo fixado pela lei; 2) regularidade formal - a interposição do recurso há de observar determinados preceitos de forma, que variam de uma para outra figura recursal; 3) preparo - consiste no pagamento prévio das despesas relativas ao processamento do recurso. ${ }^{182}$

Nelson Nery Junior também adere à classificação de pressupostos intrínsecos e extrínsecos, mas, para os pressupostos intrínsecos, leva em conta aqueles que dizem respeito à decisão recorrida em si mesma considerada, ou seja, o seu conteúdo e a sua forma no momento em que a decisão foi prolatada, sendo eles: o cabimento, a legitimidade para recorrer e o interesse em recorrer. Já os fatores extrínsecos concernem a fatores externos à decisão judicial que se pretende impugnar, sendo normalmente posteriores a ela, deles fazendo parte a tempestividade, a regularidade formal, a inexistência de fato impeditivo ou extintivo do poder de recorrer e o preparo. ${ }^{183}$

Teresa Arruda Alvim Wambier entende que o pressuposto de inexistência de fato impeditivo ou extintivo do direito de recorrer não deveria constar desse rol, uma vez que ele seria perfeitamente subsumível ao interesse da parte em recorrer. ${ }^{184}$

Critério diverso adota Moacyr Amaral Santos, o qual considera o recurso em si mesmo ou a pessoa do recorrente. Classifica os pressupostos de admissibilidade recursal em objetivos: recorribilidade do ato decisório, tempestividade, singularidade do recuso,

\footnotetext{
${ }^{181}$ CARPI, Federico. L'acesso alla Corte di Cassazione ed il nuovo sistemi di filtri. Rivista Trimestrale di Diritto e Procedura Civile. Milano, anno LXIV, n. 3, p. 774-775, 2010.

182 BARBOSA MOREIRA, 1994a, p. 142-144.

${ }^{183}$ NERY JR., 2014. item 3.4.1, p. 266.

${ }^{184}$ WAMBIER, Teresa Arruda Alvim. O novo regime do agravo. 2. ed. São Paulo: RT, 1996. p. 98-99.
} 
adequação do recurso e preparo, e em subjetivos: a legitimidade, renúncia e aquiescência. ${ }^{185}$

Para a finalidade deste estudo, adotaremos a classificação esboçada por José Carlos Barbosa Moreira por nos parecer a que mais se coaduna com os nossos objetivos, ou seja, requisitos intrínsecos que se referem à própria existência do direito de recorrer: cabimento e adequação, interesse, legitimidade e inexistência de fato impeditivo ou extintivo; e requisitos extrínsecos: que dizem respeito ao modo de exercer esse direito: tempestividade, regularidade formal e preparo, que a seguir serão explicados:

\subsubsection{Requisitos intrínsecos}

\subsubsection{Cabimento e adequação}

O cabimento é o primeiro pressuposto de admissibilidade de qualquer recurso, pois é necessário verificar se o ato é ou não recorrível, deve estar previsto em lei, além de ser adequado para impugnar a decisão que prejudica o recorrente.

O exame do cabimento se realiza por meio de dois ângulos distintos, mas complementares: a recorribilidade do ato e a propriedade do recurso eventualmente interposto, ou seja, avaliam-se a aptidão do ato a ser impugnado e o recurso adequado que está taxativamente enumerado no artigo 496 do Código de Processo Civil. ${ }^{186}$

O artigo 504 do Código de Processo Civil prescreve que dos despachos não cabe recurso. Pode-se afirmar que os despachos de mero expediente se limitam a dar impulso processual e não possuem conteúdo decisório, razão pela qual são irrecorríveis. São exemplos de despachos de mero expediente quando o juiz determina prazo para uma das partes falar nos autos ou quando designa data e hora da audiência etc.

\footnotetext{
${ }^{185}$ AMARAL SANTOS, Moacyr. Primeiras linhas de direito processual civil. 18. ed. São Paulo: Saraiva, 1997. v. 3, p. 83-90.

${ }^{186}$ ASSIS, 2008, p. 136; Idem, 1999. p. 15.
} 
Se o juiz decide alguma questão, o ato sai do âmbito dos despachos, e nesse caso passa a ser recorrível, o que pode suceder inclusive quando a parte impugna a correção de um despacho, suscitando uma questão, a cujo respeito o juiz profere uma decisão.

José Carlos Barbosa Moreira afirma que o exame da jurisprudência demonstra que muitas vezes atos judiciais de nítido conteúdo decisório recebem a falsa qualificação de “despachos de mero expediente” e exemplifica: o ato que "indefere pedido para que sejam riscadas determinadas expressões dos autos”, ou “fixa liminarmente os honorários do advogado, na ação de despejo por falta de pagamento”, ou “concede prazo para complementar o depósito, na consignação de pagamento", ou "indefere pedido do autor para que o juízo o ajude a localizar o réu, ainda não citado”, ou "determina ou indefere segunda perícia”, ou “delibera a partilha, em inventário”. Salienta que o ato que "indefere” algum requerimento, é ato decisório, é um dos possíveis modos de decidir. ${ }^{187}$

O cabimento do recurso está ligado às ideias de recorribilidade do pronunciamento e adequação do recurso. Exemplificando: falta o requisito cabimento, quando o recorrente interpõe recurso contra decisão irrecorrível, ou interpõe recurso errado contra decisão recorrível. $^{188}$

Importante salientar que os atos recorríveis são atos judiciais praticados pelo juiz e nem sempre é fácil identificar a sua natureza jurídica, o que, consequentemente, dificulta a verificação de qual é o recurso cabível para contestar a decisão perante o juízo ad quem.

O Código de Processo Civil, no artigo 162, define a natureza dos pronunciamentos judiciais, e no capítulo concernente aos recursos define qual tipo de recurso caberá para cada pronunciamento e quais pronunciamentos são irrecorríveis. Assim, no artigo 504 dispõe que dos despachos não cabem recursos; no artigo 513 define que da sentença caberá recurso de apelação; e no artigo 522 estabelece que das decisões interlocutórias cabe o recurso de agravo, retido nos autos ou por instrumento. Além disso, o artigo 530 define que contra decisões não unânimes cabem embargos infringentes; e o artigo 535 prevê que contra decisões obscuras, contraditórias ou omissas cabem embargos de declaração. Além disso, os recursos ordinários estão previstos no art. 539, o artigo 541 disciplina as hipóteses de cabimento de recurso especial e recurso extraordinário e o artigo 546 prevê os embargos de divergência.

\footnotetext{
${ }^{187}$ BARBOSA MOREIRA, 2007b, p. 271-272.

${ }^{188}$ MEDINA et WAMBIER, 2011. p. 88.
} 
A ausência de recorribilidade, ou da adequação, implicará a inadmissibilidade ou o não conhecimento do recurso. Embora, aparentemente, seja, para a maioria dos casos, relativamente fácil a identificação do recurso cabível a cada decisão, na prática pode ocorrer “confusão” na identificação entre decisão interlocutória e sentença, e consequentemente poderá se dar a interposição do recurso errado. Assim, se a parte diante de uma decisão interlocutória, achando tratar-se de sentença, interpõe o recurso de apelação, tecnicamente esse recurso não será conhecido por falta de cabimento. Esse problema tem sido contornado pela aplicação do princípio da fungibilidade recursal, desde que haja dúvida objetiva quanto ao recurso cabível e inexista erro grosseiro. ${ }^{189}$

Segundo Araken de Assis, é necessário frisar que não importa a forma ou o nome porventura atribuídos ao ato pelo órgão judiciário, pois o que interessa, para o cabimento do recurso, é a precisa adequação do provimento à tipologia legal. Assim, se o órgão judiciário nominar erroneamente o próprio ato, valerá a natureza do ato, pois a recorribilidade se funda na natureza do provimento, e não na denominação errônea. ${ }^{190}$

Dessa forma, para identificar qual o recurso adequado para atacar certo pronunciamento judicial, o recorrente deverá levar em conta a natureza do ato que pretende impugnar, visto que a lei empresta relevância somente ao conteúdo do ato, para fixar-lhe a natureza. Se um juiz denominou de "sentença” determinada decisão, mas, substancialmente, indeferiu uma prova pericial, este ato será decisão interlocutória, pois não colocou termo ao processo. ${ }^{191}$ Nesse caso, o recurso cabível, é o agravo e não a apelação. $^{192}$

\footnotetext{
${ }^{189}$ CHEIM JORGE, 2009, p. 101.

190 ASSIS, 2008. p. 137.

191 NERY JR., 2014. item 3.4.1.1, p. 272.

${ }^{192}$ A nova redação do artigo 162, § $1 .^{\circ}$, determinada pela Lei 11.322/2005 causa dificuldade na interpretação do conceito de sentença. Segundo José Roberto dos Santos Bedaque, há casos em que o juiz resolve o mérito e o processo não é extinto, por exemplo, o indeferimento liminar de demanda reconvencional por decadência ou prescrição, resolução de declaratória incidental. Se tais casos passam a configurar sentença, o recurso cabível é apelação, cuja interposição e processamento implicam a remessa dos autos ao tribunal, com a consequente paralisação do processo. Isso leva a pensar na apelação por instrumento, a fim de que, não extinto o processo mediante sentença de mérito, possa a relação processual desenvolver-se em primeiro grau e o recurso possibilitar a devolução unicamente da questão resolvida (Algumas considerações sobre o cumprimento de sentença condenatória. Revista do Advogado, São Paulo, ano XXVI, n. 85, p. 72, 2006a). Posição diversa tem Humberto Theodoro Júnior, para quem sentença definitiva é aquela que decide o mérito da causa, no todo ou em parte. Como a resolução do mérito da causa pode ser fracionada, não se deve considerar sentença senão o julgamento que completa o acertamento em torno do objeto do processo. As soluções incidentais de fragmentos do mérito são decisões interlocutórias (art. 162 § 2. ${ }^{\circ}$ ), ainda quando versem sobre questões de direito material. Sentença, realmente, ocorre quando, no primeiro grau de jurisdição, o juiz conclui a fase cognitiva do processo (2009, item 484, p. 495).
} 
Na opinião de Nelson Nery Junior, há hipóteses de sentença que não decidem o mérito (art. 162, § $1 .^{\circ}$ ), sendo a recíproca verdadeira, quando, por exemplo, o juiz pronuncia a prescrição ou a decadência em relação a um dos litisconsortes, prosseguindo o processo quanto aos demais, e neste caso, embora o juiz tenha decidido o mérito (artigo 269, IV), não pronunciou sentença. Nessas circunstâncias, dado o princípio da singularidade ou unicidade, não se pode interpor mais de um tipo de recurso contra a mesma decisão, assim não se pode agravar e apelar ao mesmo tempo, ainda que a decisão contenha matérias que poderiam ensejar ambos os recursos. Essa regra não pode ser confundida com a prática de mais de um ato processual, em que numa mesma oportunidade o juiz profere mais de uma decisão, pois nesse caso os atos serão diferentes e recorríveis por recursos distintos, dependendo da hipótese ocorrida. A título de exemplo, numa audiência de conciliação, instrução e julgamento, de rito sumaríssimo, o juiz profere decisão sobre a incompetência absoluta na fase postulatória, do indeferimento da oitiva de testemunhas na fase instrutória e a decisão de mérito na fase decisória, ocorrendo, assim, diversos atos recorríveis por vários e diferenciados recursos. Assim, para impugnar o indeferimento da prova ou o julgamento da preliminar, o recurso cabível é o agravo e para atacar a decisão de mérito, cabe o recurso de apelação. ${ }^{193}$

No mesmo sentido, posiciona-se Araken de Assis, quando o órgão judiciário emite decisão interlocutória nos termos do artigo 269, IV, estará emitindo uma decisão de mérito, mesmo que o provimento se ressinta da falta de caráter final que a definição de sentença exige. Na conformidade com o artigo 162, § 1. ${ }^{\circ}$, o ato somente poderá ser impugnado pelo recurso de apelação. Prevalece o conteúdo do ato, ou seja, a resolução acerca do mérito, ou a inadmissibilidade da ação (artigo 267), absorve a simultânea resolução de questões prévias. É, pois, sentença para fins de recurso. ${ }^{194}$

O rol taxativo do artigo 496 do Código de Processo Civil permite estabelecer quais atos comportam recurso e qual o recurso adequado.

De acordo com o artigo 504, os despachos, definidos no artigo 162, § 3. ${ }^{\circ}$, e às vezes designados de “expediente” no artigo 189, I, todos do Código de Processo Civil, não desafiam qualquer recurso, pois não contêm um grau mínimo de conteúdo decisório e eliminam a necessidade de impugnação do ato. No entanto, se houver um grau decisório

\footnotetext{
193 NERY JR., 2014. item 3.4.1.1, p. 273.

${ }^{194}$ ASSIS, 2008. p. 142.
} 
mínimo, não descaracteriza o pronunciamento enquanto despacho, mas o torna recorrível, porque apto a gerar prejuízo. ${ }^{195}$

Contra as sentenças conforme o artigo 162, § 1. ${ }^{\circ}$, a teor do artigo 513, caberá apelação (artigo 496, I), todos do Código de Processo Civil. As decisões interlocutórias, definidas no artigo 162, § 2. ${ }^{\circ}$, atraem agravo (artigo 496, II), conforme o artigo 522, retido nos autos ou por instrumento. 196

Os embargos infringentes podem ser propostos quando os acórdãos não forem decididos por unanimidade conforme os artigos 496, III, e 530 do Código de Processo Civil; existindo questão federal, mediante recurso especial, conforme artigo 105, III, da Constituição Federal, combinado com o artigo 496, VI, do Código de Processo Civil. Se for configurada questão constitucional, de conformidade com o artigo 102, III, da Constituição Federal, combinado com o artigo 496, VII, do Código de Processo Civil, poderá ser interposto recurso extraordinário, e também por recurso extraordinário no caso do artigo 539 do Código de Processo Civil. ${ }^{197}$

Os atos monocráticos do relator são recorríveis quando a lei expressamente estabeleça o recurso próprio, a exemplo da hipótese prevista no artigo 557, $\S 1$. $^{\circ}$, do Código de Processo Civil. Araken de Assis aduz que “o 'agravo regimental' promiscuamente criado pelo regimento interno dos Tribunais não se mostra admissível. E a razão é curial: não compete aos tribunais legislar sobre direito processual, matéria reservada à União (art. 22, I, da CF/1998)”. 198

Dessas decisões do relator também não cabe recurso extraordinário ou recurso especial, por lhes faltar o caráter final. A interposição de todos os recursos porventura cabíveis na instância ordinária é exigência prevista na Súmula 281 do Supremo Tribunal Federal: "É inadmissível o recurso extraordinário, quando couber, na Justiça de origem, recurso ordinário da decisão impugnada”.

\subsubsection{Legitimidade para recorrer}

\footnotetext{
${ }^{195}$ ARRUDA ALVIM, Teresa. Despachos, pronunciamentos recorríveis? Revista de Processo. São Paulo, n. 58, p. 50, 1990.

${ }^{196}$ WAMBIER, 1996. p. 85.

197 ASSIS, 1999. p. 20.

${ }^{198}$ Idem, 2008. p. 144.
} 
Da mesma forma que a parte necessita ter legitimidade ad causam para ajuizar a ação, sem a qual faltaria uma das condições da ação, o que impediria a apreciação do mérito, também para recorrer, a legitimidade é um dos requisitos para a parte exercer o direito a uma segunda decisão. A inexistência desse requisito induzirá à inadmissibilidade do recurso.

O artigo 499 limita o rol dos recorrentes, relacionando quem tem legitimidade recursal, quais sejam: a parte vencida, o terceiro prejudicado e o Ministério Público. Esse dispositivo trata tanto da legitimidade quanto do interesse em recorrer, pois não basta somente ter legitimidade, é necessário, também, o interesse em recorrer.

\subsection{Legitimidade de quem é parte}

Conceituam-se partes, os sujeitos interessados da relação processual, ou os sujeitos do contraditório instituído perante o juiz. ${ }^{199}$ São sujeitos interessados em razão de estarem ali sempre em defesa de alguma pretensão própria ou alheia, no aguardo para receberem os efeitos do provimento final do processo. Participam dos atos processuais suportando ou beneficiando-se com os efeitos substanciais diretos ou indiretos decorrentes do provimento final. A tutela jurisdicional a ser concedida será endereçada a uma das partes (vencedora), impondo à outra (vencida) o sacrifício de uma pretensão. ${ }^{200}$

A lei deixa claro que não basta ser "parte” para recorrer, é necessário que tenha saído vencida, ou seja, que tenha tido prejuízo e que haja o anseio do recorrente de obter uma melhora na sua condição.

Figuram na condição de parte o opoente, o denunciado da lide, o chamado ao processo e o assistente litisconsorcial. O denunciado e o chamado atuam como parte superveniente a partir do momento em que uma das partes originárias suscita o incidente de intervenção, independentemente da sua efetiva participação no processo. Quanto ao nomeado à autoria, é parte uma vez admitida a substituição do réu originário. Também assume a condição de parte o adquirente ou cessionário que substituir o alienante ou cedente, pois passa a conduzir a atividade processual em nome próprio, com o status de

\footnotetext{
${ }^{199}$ LIEBMAN, Enrico Tullio. Manual de direito processual civil. Tradução e notas de Cândido Rangel Dinamarco. 2. ed. Rio de Janeiro: Forense, 1985. v. 1, p. 89.

${ }^{200}$ DINAMARCO, 2009a, v. II, p. 252.
} 
parte principal, assumindo todos os poderes, ônus e expectativas processuais inerentes a essa condição, sem qualquer subordinação ao alienante ou cedente. Também recorre como parte o sucessor a título universal ou singular. ${ }^{201}$

Dependendo da situação concreta, há uma sobreposição entre legitimidade e interesse recursal, como demonstra, por exemplo, a Súmula 318 do Superior Tribunal de Justiça: "Formulado pedido certo e determinado, somente o autor tem interesse recursal em arguir vício da sentença ilíquida”.

\subsection{Legitimidade do terceiro}

A lei não outorga a qualquer terceiro a possibilidade de impugnar os atos decisórios proferidos em um determinado processo. Segundo o artigo $499 \S 1$. $^{\circ}$, somente aqueles que demonstrarem "o nexo de interdependência entre o seu interesse de intervir e a relação jurídica submetida à apreciação judicial” é que poderão recorrer, ou seja, apenas aqueles a quem a relação jurídica poderá afetar diretamente o direito de que é titular. ${ }^{202}$

Salienta Cassio Scarpinella Bueno que, quanto ao terceiro prejudicado, o $\S 1$. $^{\circ}$ do artigo 499 do Código de Processo Civil se refere ao terceiro que ainda não interveio no processo, devendo ele demonstrar como o seu direito foi direta ou indiretamente afetado naquela decisão em que não é parte, revelando exatamente o que o prejudicou. ${ }^{203}$

O processualista enfatiza a diferença entre o terceiro prejudicado mencionado no $\S$ 1. ${ }^{\circ}$ do artigo 499 e os terceiros que já intervieram no processo antes de ser proferida qualquer decisão, ou seja, intervindo como assistentes simples ou litisconsorciais buscam favorecimento direto ou indireto nas decisões a serem proferidas, enquanto o terceiro prejudicado busca afastar a decisão que lhe prejudicou. ${ }^{204}$

O recurso de terceiro prejudicado equivale a uma intervenção de terceiro na fase recursal, o que significa que todos os terceiros que podem recorrer são aqueles que poderiam ter intervindo no processo na qualidade de assistentes. ${ }^{205}$

\footnotetext{
${ }^{201}$ ASSIS, 2008. p. 148.

202 Ibidem, p. 152.

203 BUENO, 2010. p. 71.

${ }^{204}$ Ibidem.

${ }^{205}$ Nesse sentido, Nelson Nery Jr. aduz que esse raciocínio deflui: “a consequência de que o nosso recurso de terceiro prejudicado não se identifica com a opposizione di terzo do direito italiano nem com a tierce
} 
O terceiro prejudicado não tem legitimidade para recorrer adesivamente, uma vez que, antes da sua intervenção no processo, é inviável verificar qual a sua pretensão, além da literal interpretação do $\S 1 .^{\circ}$ do artigo 499 e do caput do artigo 500 do Código de Processo Civil. $^{206}$

\subsection{Legitimidade do Ministério Público}

A legitimidade do Ministério Público é verificada quando ele atua como parte, previsto no artigo 81, exercendo o direito de ação, ou quando figura como fiscal da lei, custos legis, para proteger outros interesses, conforme artigo 82, ambos do Código de Processo Civil. $^{207}$

Ao recorrer contra decisão proferida em processo em que funcionava como fiscal da lei, o Ministério Público assume a condição de parte no procedimento recursal, com os mesmos poderes e ônus, de forma semelhante ao que ocorre quando exerce o direito de ação, com ressalva a regras especiais, como é o caso da dispensa de preparo nos recursos que interpõe. ${ }^{208}$

O $\S 2 .^{\circ}$ do artigo 499 do Código de Processo Civil em sua literalidade alude aos processos em que o Ministério Público “oficiou como fiscal da lei”, ou seja, nos processos em que a sua intervenção já ocorreu. No entanto, a sua legitimidade é idêntica, nos casos em que deveria intervir, mas que ainda não o fez, pois inexiste razão plausível para negar ao Ministério Público o direito de corrigir o processo viciado pela falta de sua intervenção. ${ }^{209}$

\subsubsection{Interesse de recorrer}

opposition do direito francês, que são um misto de recurso e de ação revocatória” (2014. p. 311). No mesmo sentido: MEDINA et WAMBIER, 2011, p. 91.

${ }^{206}$ BUENO, 2010. p. 71.

${ }^{207}$ Nesse sentido: PINTO, 2004. p. 69. Salienta o autor: "para que se dê essa legitimidade recursal basta que se configure um dos pressupostos de intervenção do Ministério Público como fiscal da lei, previstos no art. 82 do CPC. Não há necessidade de que tenha efetivamente ingressado no processo. Ainda que não o tenha feito, sendo caso de intervenção, terá o Ministério Público legitimidade para recorrer da decisão”.

208 BARBOSA MOREIRA, 2010. item 165, p. 297.

${ }^{209}$ Ibidem, p. 297-298. No mesmo sentido: ASSIS, 2008. p. 150. 
O interesse em recorrer repousa sempre no binômio utilidade + necessidade, ou melhor, na utilidade da providência judicial almejada e na necessidade da providência judicial, ou seja, na via que se escolhe para se obter o que se deseja.

A utilidade é apurada pelo gravame, também denominado "prejuízo” ou “sucumbência”, ou seja, é experimentado pela parte ou pelo terceiro prejudicado, quando é proferida a decisão. A necessidade corresponde à interposição do recurso que objetiva a modificação da decisão. ${ }^{210}$

Segundo Barbosa Moreira, para que haja interesse é suficiente que a possibilidade de melhoria se configure no tocante a qualquer tópico do julgado, mesmo que secundário. ${ }^{211}$ A título exemplificativo, se a sentença julgou procedente o pedido principal do autor, mas negou a condenação do adversário ao pagamento dos honorários de sucumbência, haverá interesse do autor em recorrer e pleitear a verba honorária. Inclusive, haveria interesse se a pretensão fosse, simplesmente, a majoração da verba honorária.

O autor salienta que a ênfase do interesse recursal paira mais na prospectiva do que é possível ao recorrente esperar no novo julgamento, do que na retrospectiva daquilo que já se decidiu no julgamento impugnado. Esse modo de considerar permite a uniformização dos termos, quer se trate de parte, terceiro prejudicado ou Ministério Público, enquanto atuar como fiscal da lei, sendo que, neste último caso, a utilidade ou proveito não se destina a beneficiar diretamente o Ministério Público que interpõe recurso, mas como satisfação que poderá ter, em decorrência do pronunciamento do órgão ad quem, o interesse (na observância do direito objetivo) sustentado pelo Ministério Público no processo. $^{212}$

Há questões curiosas quanto ao interesse de agir na cumulação de pedidos, conforme exemplifica Cassio Scarpinela Bueno: se o autor formula pedido alternativo, o acolhimento de qualquer um deles significará que sua pretensão foi satisfeita. Nesse sentido, não existirá para ele o interesse em recorrer, pois não há como conceber, nesse caso, alguma utilidade prática em recorrer da decisão, uma vez que a concessão de um dos pedidos exclui e impossibilita a tutela do outro pedido alternativo. Diferente é o caso de pedido subsidiário, em que há interesse recursal para o autor quando não for acolhido o pedido principal, ou seja, a utilidade por ele perseguida em juízo subsiste mesmo quando a

\footnotetext{
${ }^{210}$ BUENO, 2010. p. 73.

${ }^{211}$ BARBOSA MOREIRA, 2010. item 167, p. 301.

${ }^{212}$ Ibidem, p. 299-300.
} 
sentença acolhe o pedido secundário, na medida em que ele pode, por meio do recurso, atingir situação jurídica mais favorável e mais útil do que aquela que lhe fora concedida na sentença. $^{213}$

José Carlos Barbosa Moreira enfatiza que a simples discrepância entre as razões de decidir e os argumentos invocados pela parte não legitima a interposição de recurso, o que significa que só se admite recurso contra o “dispositivo”, e não contra a “motivação” da sentença. Assim, a existência ou inexistência do interesse em recorrer teria de se verificar à luz da conclusão, e não do raciocínio armado para produzi-la; ressalvados os casos em que a própria lei atribui importância prática para a motivação, como é o caso da sentença de improcedência da ação popular, cuja força varia de acordo com o fundamento do decisum. $^{214}$

Outro aspecto apontado por Barbosa Moreira, relativo ao interesse em recorrer, é a necessidade. Da mesma forma que o interesse em agir, como condição de legítimo exercício da ação, está ligado a uma situação em que se torna necessário para o autor o ingresso em juízo, por não existir alternativa, também o interesse em recorrer, como requisito da admissibilidade do recurso, pressupõe a necessidade do recorrente para atingir o resultado prático que objetiva como meta. Assim, se o autor sai vencido numa ação de cobrança, em razão de o seu pedido ter sido julgado improcedente, a princípio teria interesse em recorrer. No entanto, se o réu, logo após a prolação da sentença, oferece em pagamento a importância cobrada, mais os acessórios, o objetivo do autor estará satisfeito, sem a necessidade de recorrer, pois já alcançou o seu objetivo. Contudo, se mesmo assim o autor apelar da sentença, deve o recurso ser considerado inadmissível por falta de interesse. Nesse caso, além de faltar a utilidade, não há também o aspecto relativo à necessidade, o que induz ao não interesse em recorrer, pois o objetivo almejado pelo autor, ao propor a ação, já foi concretizado. No tocante à “parte vencida”, deve-se entender que vencida é a parte quando a decisão lhe tenha causado prejuízo, ou que lhe tenha colocado em situação menos favorável daquela que gozava antes do processo, que tenha acolhido a pretensão do adversário, ou tenha repelido alguma de suas pretensões. Em qualquer dessas hipóteses surge o interesse recursal que se consubstancia no interesse em melhorar o teor da condenação, ou seja, em minimizar o prejuízo provocado pela decisão recorrida. ${ }^{215}$

\footnotetext{
${ }^{213}$ BUENO, 2010. p. 73-74.

214 BARBOSA MOREIRA, 2010. item 167, p. 302.

215 Ibidem, p. 303.
} 
Em que pese a amplitude do interesse recursal, é suficiente que a possibilidade de melhoria se configure em qualquer um dos tópicos da sentença, seja principal ou secundário, por inexistir a exigência quanto a graus de relevância.

Como requisito de admissibilidade, o interesse recursal pressupõe a necessidade que o recorrente tem de apelar para alcançar o resultado prático que tem em vista.

\subsubsection{Inexistência de fato extintivo do direito de recorrer}

Para que os recursos sejam admitidos, não deve haver fato impeditivo ou extintivo do direito de recorrer. A ocorrência de algum fato que enseja a extinção ou impeça o direito de recorrer faz com que o recurso interposto não seja conhecido, o que leva ao juízo negativo de admissibilidade.

A presença de qualquer fato extintivo, ou impeditivo ao direito de recorrer, enseja que o recurso não seja conhecido e seja inadmissível, ocorrendo o juízo negativo de admissibilidade do recurso. Os fatos extintivos do direito de recorrer correspondem à renúncia ao recurso e à aquiescência à decisão. Os fatos impeditivos são a desistência do recurso ou da ação, o reconhecimento jurídico do pedido, a renúncia ao direito sobre o qual se funda a ação. ${ }^{216}$

José Carlos Barbosa Moreira aduz que a renúncia pressupõe que o recurso da decisão já proferida ainda não tenha sido interposto, é a abdicação ao direito de recorrer. É ato pelo qual uma pessoa manifesta a vontade de não interpor o recurso de que poderia se valer para impugnar determinada decisão. Sempre será prévia à interposição, uma vez que a renúncia torna inadmissível o recurso. Já a desistência ocorre quando o recorrente já interpôs o recurso, é o ato pelo qual manifesta ao órgão judicial a vontade de que o recurso interposto não seja julgado, ou seja, que deixe de ser processado, é admitida conforme o artigo 501 do Código de Processo Civil, ou seja, independentemente da aceitação da outra parte. A lei não exige forma especial para a renúncia, porém entende que deve constar de petição dirigida ao órgão perante o qual tramita o processo, ou em ata de audiência. A renúncia, validamente manifestada, torna inadmissível o recurso que porventura tenha sido interposto por aquele que renunciou, dado que é fato extintivo do direito de recorrer. A

${ }^{216}$ NERY JR., 2014. item 3.4.1.6, p. 366-367. 
renúncia do direito de recorrer, desde que não exista outro óbice, faz com que a decisão transite imediatamente em julgado.

Outra questão importante quanto à renúncia, apontada pelo processualista, é em caso de litisconsórcio, visto que, da mesma forma que independe de aceitação da parte contrária, também independe de consentimento dos litisconsortes do renunciante. O fato de um dos colitigantes ter renunciado ao seu recurso não influi na situação dos demais, podendo cada qual recorrer individualmente até que sobrevenha alguma causa de inadmissibilidade, por exemplo, o esgotamento do prazo. Salienta ainda o processualista que, de qualquer forma, caso um litisconsorte renuncie ao recurso e outro litisconsorte recorra, se a matéria se sujeita ao regime comum do litisconsórcio, se o órgão ad quem dá provimento ao recurso para reformar a decisão, o resultado será um para o renunciante e outro para o recorrente. No entanto, caso se trate de litisconsórcio de regulamentação uniforme, essa possibilidade fica previamente excluída. Por fim, o autor ainda levanta uma questão bastante interessante quanto a renúncia, no que diz respeito à aceitação ou não do recurso adesivo daquele que renunciou dentro do prazo normal de interposição, e salienta que, no silêncio da nossa lei, parece razoável lançar mão da analogia e aplicar à renúncia o que se estabelece para a aquiescência, cujo artigo 503 do Código de Processo Civil é categórico em recusar a possibilidade de recorrer a quem aceitou, expressa ou tacitamente, a decisão, e não faz qualquer distinção entre recurso independente ou recurso adesivo. Não vê obstáculo, porém, em aceitar como válida ressalva, porventura feita expressamente pelo recorrente, pois quem pode renunciar ilimitadamente também pode se reservar a possibilidade de fazê-lo em caráter adesivo, tratando-se dessa forma de uma renúncia parcial. $^{217}$

A aquiescência é fato impeditivo ao direito de recorrer, pois consiste na aceitação tácita ou expressa, no todo ou em parte, do ato decisório conforme artigo 503 do Código de Processo Civil. A faculdade compete a todos os legitimados para recorrer do pronunciamento. Temporalmente, a aquiescência poderá ocorrer antes ou depois da interposição do recurso, mas sempre após do ato decisório. Os seus efeitos não diferem daqueles já examinados quanto a renúncia e a desistência. ${ }^{218}$

${ }_{218}^{217}$ BARBOSA MOREIRA, 2010. item 185, p. 341-345.

${ }^{218}$ ASSIS, 1999. p. 33. 


\title{
4.4.2. Requisitos extrínsecos
}

\subsubsection{Tempestividade}

O desenvolvimento do processo se dá por meio de uma sequência prática e ordenada de atos praticados pelas partes, juiz e auxiliares de justiça objetivando a solução do litígio. A lei processual prevê prazos para a prática dos atos processuais, os quais devem ser obedecidos, visto que, na maioria das vezes, quando desrespeitados, geram preclusão temporal, o que impossibilita a prática deles. Os recursos são atos processuais e, portanto, também devem ser interpostos dentro dos prazos impostos pela legislação, e são considerados tempestivos quando interpostos no prazo legal, ou seja, quando respeitam o prazo final para a sua proposição. ${ }^{219}$

Todo recurso deve ser proposto no prazo que a lei lhe assinalar, sob pena de preclusão. Se o recurso for interposto além do prazo, ocorrerá a intempestividade e ele será inadmissível.

Heitor Vitor Mendonça Sica, ao discorrer sobre preclusão e dinâmica processual, salienta que:

\begin{abstract}
Os momentos em que o impulso processual incumbe às partes são justamente aqueles em que materialmente se mostra impossível ao juiz dar o direito à prática de determinado ato por precluso e dar prosseguimento ao processo até o final, bem como nos casos em que o interesse particular prepondera completamente sobre o público. ${ }^{220}$
\end{abstract}

Nesse caso, o impulso processual de recorrer cabe à parte sucumbente, que deverá, dentro do prazo que a lei estabelece, interpor o recurso, pois, se não o fizer, ocorrerá a preclusão.

O artigo 508 do Código de Processo Civil uniformiza o prazo dos recursos de apelação, embargos infringentes, recurso ordinário, recurso especial e recurso extraordinário, que tanto para interpor quanto para responder é de 15 dias.

No recurso de agravo o prazo para a sua interposição é de dez dias conforme artigos 522, caput, e 544, caput, no agravo "interno" contra ato do relator que negou seguimento, desproveu ou proveu recurso (artigo 557, § $1 .^{\circ}$ ), e não admitiu os embargos infringentes, é

\footnotetext{
${ }^{219}$ PINTO, 2004. p. 71.

${ }^{220}$ SICA, Heitor Vitor Mendonça. Preclusão processual civil. 2. ed. São Paulo: Atlas, 2008. p. 283.
} 
de cinco dias, conforme artigo 532; para os embargos de declaração, o prazo é de cinco dias, conforme artigo 536, todos do Código de Processo Civil.

As disposições de leis especiais diversificam mais os prazos: é de dez dias o prazo para interpor embargos infringentes, nas causas de alçada, consoante o artigo 34, § 2. ${ }^{\circ}$, da Lei 6.830/1980, e, igualmente, é de dez dias o prazo para interpor o recurso inominado, mas similar à apelação, previsto no artigo 42 da Lei 9.099/1995. Para agravar da decisão do presidente do tribunal de segundo grau, Tribunal de Justiça e Tribunal Regional Federal, e dos tribunais superiores, Superior Tribunal de Justiça e Supremo Tribunal Federal, concedendo ou denegando a suspensão liminar em ação civil pública, é de cinco dias, a teor do artigo 12, § 1. ${ }^{\circ}$, da Lei 7.347/1985 e do artigo 25, § 2. ${ }^{\circ}$, c/c o artigo 39 da Lei 8.038/1990. Já o mesmo agravo, tratando-se de ato do presidente do tribunal de segundo grau, contra o deferimento ou o indeferimento de suspensão de liminar em mandado de segurança, tem o prazo de dez dias, conforme dispõe o artigo $4 .^{\circ}$ da Lei 4.348/1964; cuidando-se de ato do presidente do Superior Tribunal de Justiça e do Supremo Tribunal Federal, é de cinco dias, aplicando-se os artigos 25, 245, § 2. ${ }^{\circ}$, c/c o artigo 39 da Lei 8.038/1990.

O prazo recursal pode ser comum ou particular: se houver sucumbência recíproca, o prazo será comum; havendo sucumbência total de uma das partes, o prazo recursal será particular. Quando a sentença é proferida, em tese, o ato pode ser impugnado por embargos de declaração por qualquer das partes ou interessados e, durante essa impugnabilidade, o prazo é comum. Ultrapassado o prazo para a oposição dos embargos declaratórios, passa a ser particular se sucumbente totalmente apenas uma das partes. ${ }^{221}$

Todo recurso precisa ser interposto antes de findar o prazo previsto em lei, sob pena de preclusão. Se o recurso for interposto além do prazo previsto, será tido como inadmissível, por ser intempestivo.

O artigo 508 do Código de Processo Civil estabelece que o prazo para interposição e para resposta de apelação, embargos infringentes, recurso ordinário, recurso especial, recurso extraordinário e embargos de divergência é de 15 dias.

O Código de Processo Civil dispõe de outras regras específicas que devem ser anotadas, como é o caso do recurso de agravo de instrumento nas impugnações de decisões interlocutórias de primeira instância, cujo prazo de interposição é de dez dias, conforme

${ }^{221}$ NERY JR., 2014. item 3.4.1.4, p. 320. 
estabelece o caput do artigo 522, ou do agravo nos próprios autos, no caso de impugnação de decisão que nega trânsito a recurso especial ou extraordinário, conforme previsto no artigo 544 .

O prazo recursal fluirá da intimação, e não da data em que o órgão judiciário proferir o ato decisório, ou melhor, o prazo inicial somente começará a fluir da data em que os advogados são intimados da decisão, “sentença” ou "acórdão”, conforme regra básica inserta no artigo 242 do Código de Processo Civil. ${ }^{222}$ Além disso, o prazo para interposição dos recursos deve observar a regra do artigo 506 do Código de Processo Civil. No caso de apresentação do recurso fora do prazo, ocorrerá a preclusão temporal, a não ser que o recorrente demonstre a ocorrência de “justa causa” nos termos do art. 183 e respectivos parágrafos. $^{223}$

José Carlos Barbosa Moreira afirma que se equipara à intimação, para o efeito de fazer correr o prazo, qualquer ato inequívoco de que a parte tomou ciência da decisão (v.g., a retirada dos autos de cartório pelo advogado), e que deve ser aplicado o princípio da instrumentalidade das formas. Ressalva que não cabe tirar consequências drásticas da inobservância, se apesar desta se atingiu a finalidade do ato, sem prejuízo de qualquer das partes, e salienta que esta é a conclusão do exame sistemático de várias disposições do Código de Processo Civil sobre a matéria (artigos 154, 244, 249, § 2. $\left.{ }^{\circ}, 250\right){ }^{224}$

Para assegurar a tempestividade recursal, basta que se faça o protocolo no tempo devido, em cartório, ou em conformidade com o que dispuser a norma de organização judiciária; assim, não basta o simples despacho do juiz sem o protocolo. No entanto, a demora do cartório em juntar aos autos a petição não compromete a tempestividade. ${ }^{225}$

No peticionamento eletrônico, os atos processuais são considerados realizados no dia e hora do seu envio ao sistema do Poder Judiciário, do que deverá ser fornecido protocolo eletrônico. Quando a petição eletrônica for enviada para atender prazo

\footnotetext{
${ }^{222}$ ASSIS, 2008. p. 186.

223 Exemplifica Cassio Scarpinela Bueno: "se a única advogada constituída nos autos comprova o não cumprimento do prazo recursal pela impossibilidade de exercício profissional decorrente de enfermidade” (2010. p. 87).

${ }^{224}$ BARBOSA MOREIRA, 2007b, p. 274.

${ }^{225}$ Nesse sentido, Barbosa Moreira enfatiza que em qualquer hipótese deve respeitar-se “o horário normal do expediente forense, não se admitindo que o apelante só mais tarde, em lugar inadequado, apresente a petição ao escrivão ou ao chefe de secretaria” (2010. item 234, p. 423).
} 
processual, serão consideradas tempestivas as transmitidas até as 24 horas do seu último dia, na conformidade com o artigo 3. ${ }^{\text {, }}$ parágrafo único, da Lei n. ${ }^{o} 11.419 / 2006 .^{226}$

A contagem do prazo deve ser realizada com a aplicação do artigo 184, caput, do Código de Processo Civil, ou seja, excluindo-se da contagem o dia em que ocorreu a intimação e incluindo-se o do vencimento, prorrogando-se o vencimento para o primeiro dia útil, se o vencimento recair em domingos e feriados, ou em dia que não houver expediente forense ou encerramento antes do horário normal (artigo 184, § 1. $)$ ); a contagem do prazo inicia no dia subsequente ao da intimação (artigo 184, § 2. ${ }^{\circ}$ ). Os artigos 242 e 506 mencionam as hipóteses em que o interessado toma conhecimento da decisão judicial.

Regra especial recebem a Fazenda Pública e o Ministério Público, os quais têm prazo em dobro para recorrer na conformidade do que dispõe o artigo 188 do Código de Processo Civil, bem como a Súmula $116^{227}$ do Superior Tribunal de Justiça, que estabelece o prazo em dobro para a Fazenda Pública e o Ministério Público apresentar agravo interno de decisão proferida naquele Tribunal, mencionando, no enunciado, como "agravo regimental”. 228

O prazo para o revel recorrer conta-se da publicação da sentença em cartório ou na audiência, uma vez que os prazos contra ele correm independentemente de intimação, sendo desnecessária a intimação da parte contrária pela imprensa. ${ }^{229}$

O terceiro prejudicado tem o mesmo prazo para recorrer estabelecido para as partes.

O curso do prazo recursal pode ser suspenso ou interrompido nos casos legalmente previstos em lei. Ocorrendo a suspensão, devolve-se à parte o interregno que faltaria para o prazo se completar, se não houvesse o evento suspensivo. Na hipótese de interrupção, restituir-se-á à parte que foi beneficiada pelo evento interruptivo o prazo por inteiro, ignorando o lapso de tempo já decorrido. ${ }^{230}$

Constituem casos de suspensão do prazo recursal: a) a superveniência de recesso forense (artigo 62, I, da Lei n. ${ }^{\circ}$ 5.010, de 30.05.1966); b) o obstáculo criado pela outra

\footnotetext{
${ }^{226}$ BUIKA, Heloisa Leonor. Processo eletrônico. Revista Síntese Direito Civil e Processual Civil. São Paulo, ano XII, n. 81, p. 117, jan.-fev. 2013.

${ }^{227}$ STJ, Súmula 116. A Fazenda Pública e o Ministério Público têm prazo em dobro para interpor agravo regimental no Superior Tribunal de Justiça.

${ }^{228}$ BUENO, 2010. p. 87.

${ }^{229}$ NERY JR., 2014. item 3.4.1.4, p. 329.

${ }^{230}$ ASSIS, 2008. p. 193.
} 
parte, a exemplo da retirada dos autos de cartório, quando for comum o prazo recursal (artigo 180, Código de Processo Civil); c) a perda da capacidade processual das partes, de seu representante legal ou de seu procurador (artigo 265, I, c/c o art. 180); d) o recebimento de exceção de incompetência, de suspeição ou de impedimento (artigo 265, III, c/c o artigo 180); e) o obstáculo criado pelo juízo, a exemplo da conclusão dos autos, impedindo a consulta ao processo no cartório e a respectiva carga; f) a greve dos serviços judiciários.

Inexiste simetria rigorosa quanto aos casos de suspensão do processo (artigo 265) e aos de suspensão do prazo para interposição de recurso. Há duas exceções: ocorre, por vezes, de serem atribuídos efeitos diferentes para o mesmo evento, por exemplo, o falecimento da parte ou de seu advogado que suspende o processo (artigo 265, I), mas interrompe o prazo recursal (artigo 507); outra situação ocorre quando nega-se qualquer relevo ao evento suspensivo: a suspensão convencional do prazo (artigo 265, II) não interfere na fluência do prazo recursal já iniciado. Quanto à interrupção, o artigo 507, embora não mencione a palavra interrupção, diz “[...] será tal prazo restituído [...]” e “[...] contra quem começará a correr novamente depois da intimação [...]”, e aponta no sentido de desconsideração do lapso porventura decorrido até o surgimento dos eventos nele contemplados. Portanto, o referido artigo demonstra a interrupção do prazo nos seguintes casos: a) falecimento da parte ou de seu advogado; b) motivo de força maior; c) interposição de embargos de declaração (artigo 538, caput). ${ }^{231}$

Consideram-se interrompidos os prazos para a interposição dos recursos de apelação, embargos infringentes, recurso ordinário, recurso especial, recurso extraordinário e embargos de divergência pela interposição de embargos de declaração (artigo 538, CPC). Com a intimação da decisão dos embargos de declaração, devolve-se o prazo do outro recurso, quer hajam sido opostos contra decisão interlocutória, sentença ou acórdão. Quanto ao pedido de reconsideração, este não foi contemplado pelo legislador, e a sua interposição não suspende nem interrompe o prazo recursal contra o ato do qual se pediu a reconsideração. Logo, se entre a intimação do decisum e a decisão a respeito do pedido de reconsideração decorrer mais tempo do que o previsto para a interposição do recurso, sem que a parte tenha recorrido, terá ocorrido a preclusão. ${ }^{232}$

\footnotetext{
${ }^{231}$ ASSIS, 2008, p. 193-194.

${ }^{232}$ NERY JR., 2014. item 3.4.1.4, p. 328-329.
} 
Assim, por precaução, as partes devem pedir reconsideração e, concomitantemente, interpor o recurso apropriado no caso de agravo de instrumento, dentro do prazo recursal facultado pela lei.

Tanto os eventos suspensivos quanto os interruptivos impedem a prática de quaisquer atos processuais, e, em decorrência, nenhum dos legitimados do artigo 499, caput, pode recorrer, incluindo a parte que não é beneficiada pelo evento. Entretanto, abrese uma exceção à parte que não interpôs embargos de declaração, visto que, ao interpor o seu recurso, o faz ignorando o fato de que o prazo está interrompido por conta dos embargos de declaração opostos pelo seu adversário. ${ }^{233}$

A tempestividade deve ser provada no ato da interposição do recurso, e não em recursos posteriores destinados ao seu destrancamento. ${ }^{234}$

\subsubsection{Regularidade formal}

A regularidade formal diz respeito a elementos que devem revestir o recurso para que ele seja conhecido e cumpra a sua finalidade.

A lei determina a forma a ser observada pelo recorrente em que o recurso deve se alinhar para que venha cumprir a sua função. Uma faceta comum a todos os recursos é a exigência dos fundamentos de fato e de direito e o pedido de nova decisão, reservado a cada tipo de recurso às suas respectivas peculiaridades.

Em outras palavras, a lei pode estabelecer requisitos gerais e requisitos específicos para este ou aquele recurso, e com frequência indica os elementos que o recurso deve conter: por exemplo, os fundamentos da impugnação, ou seja, os erros in procedendo ou in iudicando, de fato ou de direito, que na visão do recorrente maculam a decisão e justificam a reforma ou a anulação da decisão recorrida. ${ }^{235}$

\footnotetext{
${ }^{233}$ ASSIS, 2008. p. 195.

${ }^{234}$ Nesse sentido: STF, Pleno, RE-AgR 536.881/MG, Rel. Min. Eros Grau, j.m.v. 08.10.2008, DJe 12.12.2008; e STF, Pleno, AI-AgR 621.919/PR, Rel. Min. Ellen Gracie, j.m.v. 11.10.2006, DJ 19.12.2006, p. 35 BUENO, 2010, p. 88).

235 BARBOSA MOREIRA, 2007b, p. 277.
} 
A título exemplificativo, o artigo 514 do Código de Processo Civil estabelece que o recurso de apelação deve conter os fundamentos de fato e de direito, bem como o pedido de nova decisão.

A regularidade formal do recurso de agravo de instrumento está discriminada no artigo 523 do Código de Processo Civil, em que, além da exposição dos fatos e pedido de reforma, deve conter o nome dos advogados que constam no processo.

Quanto aos embargos infringentes, sua formalidade está inserta no artigo 530 do Código de Processo Civil, o qual restringe o recurso quanto à matéria divergente.

A forma que os recursos especial e extraordinário devem ser interpostos está prevista no artigo 541 do Código de Processo Civil, e, quando o recurso se fundar em divergência jurisprudencial, o recorrente deverá fazer prova da divergência juntando prova extraída por meio de certidão, cópia autenticada ou pela citação do repositório de jurisprudência, oficial ou credenciado, inclusive em mídia eletrônica em que tiver sido publicada a decisão divergente, ou pela reprodução de julgado disponível na Internet, com indicação da respectiva fonte.

A fundamentação do recurso é indispensável, mesmo quando silente o texto legal, para que o recorrido e o próprio órgão ad quem se inteirem das razões efetivamente postas como base da impugnação, as quais podem não ser as mesmas daquelas alegadas na instância inferior, pois ao recorrente é facultado usar outra linha de argumentação. Como também lhe autoriza o artigo 517 do Código de Processo Civil, poderá, excepcionalmente, propor novas questões de fato, desde que prove que deixou de fazê-lo anteriormente por motivo de força maior. No entanto, aqui, “importa evitar exageros de formalismo: pode haver-se como suficiente a remissão, sem transcrição por extenso, aos argumentos utilizados no procedimento perante o juízo a quo”. ${ }^{236}$

Caso o recorrente não observe o que a lei determina quanto à formalidade, terá desatendido o requisito da regularidade formal e, em consequência, o seu recurso não será conhecido.

Flávio Cheim Jorge defende que o sistema recursal é marcado pelo fenômeno da preclusão, e, sob a ótica da regularidade formal, a preclusão consumativa impede que o recorrente, ainda que dentro do prazo recursal, possa complementar ou aditar as razões

\footnotetext{
${ }^{236}$ BARBOSA MOREIRA, 2007b, p. $277 .$.
} 
recursais. Se a parte já exerceu o direito de recorrer, este se esgota e não pode ser renovado ou mesmo exercitado, ainda que parcialmente. ${ }^{237}$

O recurso deve ser interposto por petição protocolada em cartório, ou segundo a disposição da organização judiciária, ressalvado o disposto no $\S 2 .^{\circ}$ do artigo 525 do Código de Processo Civil $^{238}$ quanto ao recurso de agravo de instrumento. Deve-se ainda ressaltar o disposto no parágrafo único do artigo 547, o qual prescreve que, a critério do tribunal, os serviços de protocolo poderão ser descentralizados mediante delegação a ofícios de justiça de primeiro grau. ${ }^{239}$

Em geral, os recursos eram protocolados em cartório por meio de petição juntando as razões recursais, mas também há casos em que podiam ser interpostos de outras maneiras, como é a forma do agravo retido contra decisões interlocutórias proferidas em audiência de instrução e julgamento que, obrigatoriamente, é interposto de forma oral, conforme determina o artigo 523 do Código de Processo Civil. ${ }^{240}$

Posteriormente, a Lei n. ${ }^{\circ}$ 9.800/1999, em seu artigo $1 .^{\circ}$, permitiu a transmissão por fac-símile: "é permitida às partes a utilização de sistema de transmissão de dados por facsímile ou outro similar, para a prática de atos processuais que dependam de petição escrita”.

Para a aceitação da transmissão do recurso por fac-símile, o recorrente devia observar os demais requisitos de admissibilidade dos recursos, tais como o recolhimento e a transmissão das guias de recolhimento do preparo e, caso existam, a reprodução de documentos que devam acompanhar o recurso, os quais também deverão ser transmitidos com a petição de interposição do recurso, ou seja, a peça recursal remetida por fac-símile deve ser exatamente a mesma, acompanhada do preparo e dos documentos que constarão dos autos. $^{241}$

Note-se que a Lei n. ${ }^{\circ}$ 9.800/1999 prevê em seu artigo 4. ${ }^{\circ}$, parágrafo único, a responsabilidade do recorrente quanto à qualidade e fidelidade do material transmitido por fac-símile e ao original entregue em juízo, prescrevendo, entre outras sanções, a litigância de má-fé, caso seja constatada discordância entre um e outro.

\footnotetext{
${ }^{237}$ CHEIM JORGE, 2013, p. 182-183.

${ }^{238}$ Essa regra está expressa no parágrafo único do artigo 506 do CPC, que diz: "No prazo para a interposição do recurso, a petição será protocolada em cartório ou segundo a norma de organização judiciária, ressalvado o disposto no $\S 2 .^{\circ}$ do artigo 525 desta lei”.

${ }^{239}$ CHEIM JORGE, 2009, p. 178.

240 Ibidem, p. 179.

${ }^{241}$ Ibidem, p. 180.
} 
Posteriormente, a Lei n. ${ }^{\circ}$ 11.419/2006 criou em definitivo as bases para a informatização do processo, tratando da comunicação eletrônica dos atos processuais, disciplinando o procedimento para as comunicações do Judiciário com as partes, com a comunicação pelo Diário Oficial on line, ou diretamente com o interessado e as comunicações diversas entre seus órgãos eletronicamente: cartas precatórias, cartas de ordem e, até mesmo, cartas rogatórias; comunicação entre o Poder Judiciário e os demais poderes.

É imprescindível que o recorrente fundamente a sua pretensão recursal para que o recorrido e o próprio órgão ad quem saibam as razões que baseiam o seu pedido de novo julgamento mais favorável.

De qualquer modo, se o recorrente entende ser a decisão injusta, deverá apontar em suas razões recursais essa injustiça, para que o órgão ad quem a confronte com as razões de decidir dadas pelo juiz ao proferir a decisão recorrida. ${ }^{242}$

Segundo Flávio Cheim Jorge, o recorrente deve demonstrar os fundamentos de fato e de direito, ou seja, os errores in judicando e/ou errores in procedendo que maculam a decisão, demonstrando o porquê de a decisão estar errada e a necessidade de sua reforma ou anulação. Com isso, o recorrente possibilitará ao recorrido oferecer a sua resposta e, ao mesmo tempo, estará indicando ao órgão ad quem qual parte da decisão está sendo impugnada e de que maneira deverá ser reformada ou anulada. ${ }^{243}$

A fundamentação do recurso é requisito essencial ao exame de seu mérito e sua ausência não acarreta a nulidade do recurso, mas impede que seja julgado o mérito recursal. Nesse caso, não se trata de nulidade, mas acarreta a inadmissibilidade do recurso, por inobservância de forma prescrita em lei. ${ }^{244}$

\subsubsection{Preparo}

O preparo consiste num dos requisitos extrínsecos de admissibilidade dos recursos, refere-se ao pagamento de exigência tributária, prevista nos artigos 77 a 80 do Código Tributário Nacional, consubstanciada em uma taxa judiciária, imprescindível e vinculada ao uso do aparelho judiciário estatal pelo jurisdicionado.

\footnotetext{
${ }^{242}$ NERY JR., 2014. item 3.4.1.5, p. 350.

${ }^{243}$ CHEIM JORGE, 2009, p. 182-183.

${ }^{244}$ NERY JR., 2014. item 3.4.1.5, p. 352.
} 
Assim, podemos afirmar que o preparo é um tributo devido em razão do serviço prestado ao requerente da tutela jurisdicional. O valor do preparo, normalmente, não cobre, nem em parte significativa, o custo do serviço do Judiciário, porém é exigido como condição sine qua non para a sua prestação. ${ }^{245}$

Em outras palavras, o preparo é o pagamento prévio das custas relativas ao processamento do recurso que deve ser realizado pelo recorrente.

O Código de Processo Civil regulamenta a exigência do preparo nos artigos 511 e 519, o que o torna norma obrigatória. Em consequência, sem a comprovação do recolhimento do preparo, o recurso não será admitido, ocorrendo a deserção. ${ }^{246}$ Assim, quando o recorrente protocolar o recurso, deverá juntar a guia de recolhimento das custas, comprovando dessa forma que o preparo foi efetuado.

Além do pagamento da taxa judiciária, também é devido o pagamento do "porte de remessa e retorno dos autos”, que não se confunde com as custas processuais, pois representa os valores pelo envio e pelo retorno dos autos do recurso ao órgão ad quem, ou seja, ao órgão que tem a competência para o seu julgamento. Esse valor se destina à remuneração do serviço de transporte físico dos autos que, normalmente, é terceirizado, prestados pelos correios, razão pela qual o custo varia em razão da quantidade de páginas (peso dos autos) e pago à parte das custas processuais. ${ }^{247}$

Quanto ao pagamento do “porte de remessa e retorno”, o Superior Tribunal de Justiça emitiu a Súmula 187 que determina: “É deserto o recurso interposto para o Superior Tribunal de Justiça, quando o recorrente não recolhe, na origem, a importância das despesas de porte de remessa e retorno dos autos”.

Anteriormente à Lei n. ${ }^{0}$ 9.756/1998 que modificou a redação do artigo 511, o preparo se completava após a interposição do recurso, aliás, após a resposta do recorrido, nos termos do revogado artigo 518, segunda parte. Se ocorresse ulterior deserção, tudo se desperdiçaria. O texto atual do artigo 511 se apresenta como um ônus de o recorrente comprovar a realização do preparo, ou seja, o recolhimento das custas por meio de guia

\footnotetext{
${ }^{245}$ ARMELIN, Donaldo. Apontamentos sobre as alterações ao Código de Processo Civil e à Lei 8.038/90, impostas pela Lei 9.756/98. In: NERY JR., Nelson; WAMBIER, Teresa Arruda Alvim (Coord.). Aspectos polêmicos e atuais dos recursos cíveis de acordo com a Lei 9.756/98. São Paulo: RT, 1999. p. 202.

${ }^{246}$ CHEIM JORGE, 2009, p. 189. No mesmo sentido: FARIA, Marcio Carvalho. O formalismo exacerbado quanto ao preenchimento de guias de preparo. Revista de Processo. São Paulo, ano 36, v. 193, p. 233, mar. 2011.

${ }^{247}$ BUENO, 2010. p. 93.
} 
própria, no ato da interposição do recurso, levando o regime desse requisito a equiparar-se à generalidade das condições de admissibilidade do recurso. ${ }^{248}$

Na ausência ou irregularidade do recolhimento das custas, ocorrerá a preclusão, sendo aplicada ao recorrente a pena de deserção, e, consequentemente, o recurso não será conhecido. $^{249}$

A palavra "deserção" deriva do termo latino deserere (desero, deseris, deserui, desertum, deserere), o qual tem o sentido de abandonar, deixar, desertar. Em consequência, a deserção induz ao entendimento de abandono do recurso, inviabilizando o julgamento das razões recursais. ${ }^{250}$

Nem todas as espécies recursais têm como requisito de admissibilidade o preparo, como é o caso dos embargos de declaração (artigo 536), agravo retido (artigo 522, parágrafo único) e o agravo previsto no artigo 544, § 2. ${ }^{\circ}$, todos do Código de Processo Civil.

Há hipóteses legais de dispensa do preparo, como é o caso do Ministério Público, da União, dos Estados e Municípios e respectivas autarquias, previsto no $\S 10^{\circ}$ do artigo 511;,como também os beneficiários da assistência judiciária gratuita, dispostos nos artigos 1. ${ }^{\circ}$, I, e 9. ${ }^{\circ}$ da Lei n. ${ }^{\circ} 1.060 / 1950$.

O juiz poderá, em casos excepcionais, desde que comprovados certos requisitos como "justa causa" ou "justo impedimento", ${ }^{251}$ postergar ou até mesmo relevar o requisito do preparo, aplicando a regra do artigo 519 do Código de Processo Civil. ${ }^{252}$

O cálculo das custas recursais varia conforme o Estado, a seção judiciária e a localidade, bem como são diversas as guias utilizadas para o seu recolhimento. A título de

\footnotetext{
${ }^{248}$ ASSIS, 2008. p. 207-208.

${ }^{249}$ NERY JR., 2014. item 3.4.1.7, p. 390.

${ }^{250}$ Nesse sentido: MEDINA, Paulo Roberto de Gouvêa. O preparo dos recursos em face da instrumentalidade do processo. In: NERY JR., Nelson; WAMBIER, Tereza Arruda Alvim (Coord.). Aspectos polêmicos e atuais dos recursos cíveis e de outras formas de impugnação às decisões judiciais. São Paulo: RT, 2001. p. 906, para quem: "A deserção implica, assim, o abandono do recurso, inviabilizando o julgamento do pedido de reexame da decisão impugnada".

${ }^{251}$ Cf. acórdão do STJ: "É o que ocorre, por exemplo, quando a apelação é protocolada no último dia do prazo, tendo-se encerrado o expediente bancário. Decidiu-se que configura 'justo impedimento' a dúvida gerada por lei estadual”. Nesse caso, admite-se o pagamento do preparo no primeiro dia útil subsequente. Em face dessa alegação, pode o juiz: a) relevar a pena, devolvendo o prazo à parte, por decisão que é, ex vi legis, irrecorrível; b) não relevar a pena, tratando-se de decisão agravável. Nesse sentido: STJ, 2. ${ }^{a}$ T., REsp 440.347/DF, Rel. Min. João Otávio de Noronha, j. 27.06.2006, DJ 03.08.2006, p. 240; e STJ, Corte Especial, REsp 331.561/SP, Rel. Min. Cesar Asfor Rocha, j. 17.11.2004, DJ 07.11.2005, p. 72.

${ }^{252}$ Nesse sentido, Marcio Carvalho Faria aduz que nesse caso "há de se observar que o ônus de comprovar o 'justo impedimento' é do recorrente, sob pena de se incidir a regra da preclusão consumativa e a consequente deserção" (2011, p. 233-234).
} 
exemplo, no Estado de São Paulo, se um recurso extraordinário for interposto contra acórdão originário do Tribunal Regional Federal da 3. ${ }^{a}$ Região, as custas devem ser recolhidas por meio de um Documento de Arrecadação de Receitas Federais (DARF), junto à Caixa Econômica Federal, e o porte e o retorno, que também devem estar anexados ao recurso, sob pena de deserção, devem ser recolhidos por meio de Guia de Recolhimento da União (GRU), junto ao Banco do Brasil, com valor variado dependendo do número de folhas constantes do processo. Se o recorrente também propuser recurso especial, haverá a necessidade de se efetuarem dois outros recolhimentos, sendo um relativo às custas e outro ao porte de remessa e retorno, cada qual contendo um código diferenciado, em guias GRU diferentes. Salientamos que, tratando-se de outro Estado, os recolhimentos são diferentes, como é o caso do Rio de Janeiro - Tribunal Regional Federal da 2. ${ }^{a}$ Região -, onde o valor do porte de remessa e retorno deve ser repartido à metade, entre o órgão a quo recolhido em DARF e o órgão ad quem recolhido em GRU. Se o acórdão recorrido for originário da Justiça Estadual, cada Estado terá a sua própria regulamentação em relação às guias, códigos e bancos específicos para o seu recolhimento. A título de exemplo, no Rio de Janeiro há a Guia de Recolhimento de Receita Judiciária (GRERJ) e em Minas Gerais há o Documento de Arrecadação Estadual (DAE). ${ }^{253}$

A Corregedoria do Tribunal de Justiça do Estado de São Paulo instituiu nova regra relativa ao preenchimento das Guias de Arrecadação, consubstanciada no Provimento CG n. ${ }^{0}$ 16/2012, cujo descumprimento invalida o documento para a comprovação do preparo.

O Provimento CG n. ${ }^{\circ}$ 16/2012 determina que conste na Guia de Arrecadação o CPF ou o CNPJ do recorrente, bem como no campo de informações complementares sejam mencionados a natureza da ação, o nome das partes (autor e réu) e a Comarca onde tramita a ação. A intenção da E. Corregedoria-Geral de Justiça é coibir o uso inadvertido de uma única guia em ações distintas, o que traria prejuízo aos cofres públicos. ${ }^{254}$

Os comprovantes das guias que não atenderem ao Provimento CG n. ${ }^{0} 16 / 2012$, ou seja, que forem omissos quanto ao preenchimento dos campos onde devem constar o CPF ou CNPJ e a identificação da causa, ou preenchidos posteriormente à autenticação mecânica ou eletrônica de pagamento, não terão validade para fins judiciais, o que significa que o recurso será considerado deserto, e, consequentemente, o juízo de

\footnotetext{
${ }^{253}$ FARIA, 2011, p. 235-236.

254 TJSP, 31. a Câmara Direito Privado, AI-0035467-89.2013.8.26.0000, Rel. Adilson de Araujo, j. 19.03.2013; AgReg-0035467-89.2013.8.26.0000, Rel. Mendes Gomes, j. 11.03.2013, 35. a Câmara Direito Privado; Ap. 0035467-89.2013.8.26.0000, Rel. Antonio Rigolin, j. 07.05.2013, 31. ${ }^{\text {a }}$ Câmara Direito Privado.
} 
admissibilidade será negativo, ou seja, não será conhecido em razão de faltar um dos requisitos para a sua admissibilidade.

\subsection{Preparo e a não ocorrência de seu fato gerador}

O preparo é a remuneração dos serviços prestados pela tutela jurisdicional e na esfera recursal deve refletir o pagamento dos seguintes atos: autuação do recurso; despesas com o envio dos autos ao órgão competente para o seu julgamento; custo aproximado da sua tramitação e do seu julgamento no órgão ad quem; eventuais despesas com o retorno dos autos à vara de origem.

Quando o recurso tramita somente no órgão de origem, por exemplo, os embargos de declaração, inexiste autuação e a peça é juntada nos próprios autos, não há fato gerador para a cobrança de custas. O mesmo ocorre quando o juízo de admissibilidade de uma apelação, por exemplo, é feito pelo órgão de origem e o recurso não é conhecido desde logo e não é enviado ao órgão ad quem.

No entanto, nessa segunda hipótese, a parte já recolheu as custas de preparo e de porte e remessa, tratando-se de uma antecipação do pagamento do tributo, fundada numa presunção legal de que seu fato gerador ocorrerá, o que pode simplesmente não acontecer. $^{255}$

Se o recolhimento das custas é feito adiantado e o serviço não chega a ser prestado, a parte teria direito à repetição do indébito, no entanto não é isso o que acontece. Outra questão que se coloca é a ocorrência gradual do fato gerador do preparo, a exigência de um mesmo valor tanto para as hipóteses de julgamento de mérito quanto para as hipóteses em que a demanda é extinta sem a sua apreciação, sendo incompatível com a isonomia tributária, pois nesses casos os contribuintes pagam contribuições iguais, mas recebem prestações jurisdicionais distintas. $^{256}$

No nosso sentir, ao ser feito o juízo de admissibilidade do recurso, seja pelo órgão $a$ quo, seja pelo órgão ad quem, o juiz ou o relator deveria julgar a questão da repetição do

\footnotetext{
255 OLIVEIRA, Bruno Silveira de; COLNALGO, Cláudio de Oliveira Santos. Preparo e deserção (réquiem a algumas inconstitucionalidades). In: OLIVEIRA et al. (Coord.). Recursos e a duração razoável do processo. Brasília: Gazeta Jurídica, 2013. p. 9.

${ }^{256}$ Ibidem, p. 9.
} 
indébito integral ou parcial, dependendo do serviço prestado pelo órgão jurisdicional ao contribuinte, no caso, ao recorrente, com base no $\S 7 .^{\circ}$ do artigo 150 da Constituição Federal:

A Lei poderá atribuir a sujeito passivo de obrigação tributária a condição de responsável pelo pagamento de imposto ou contribuição, cujo fato gerador deva ocorrer posteriormente, assegurada a imediata e preferencial restituição da quantia paga, caso não se realize o fato gerador presumido.

\subsection{Preparo e assistência judiciária}

Quanto à assistência judiciária, o seu requerimento deverá sempre ser examinado antes do juízo de admissibilidade do recurso, pois há uma relação de prejudicialidade entre o primeiro e o segundo. O pleito de assistência judiciária deverá ser formulado em qualquer fase do processo, interessando-nos, por ora, o requerimento formulado com as razões do recurso, e deve ser decidido antes do juízo de admissibilidade conforme prescreve o artigo 6. ${ }^{\circ}$ da Lei 1.060/1950, ou seja, quando a parte recorrente, inconformada com a sentença de primeiro grau, interpõe o recurso de apelação e em suas razões recursais requer a concessão do benefício da assistência judiciária, sem efetuar o preparo exigido pelo artigo 511 do Código de Processo Civil. ${ }^{257}$

Nesse caso, como o preparo é requisito extrínseco da admissibilidade recursal, podemos antever as situações de deferimento ou não do pedido de assistência judiciária, como também a sua influência no juízo de admissibilidade do recurso interposto.

Na conformidade com o artigo $4 .^{\circ}$ da Lei 1.060/1950, “a parte gozará dos benefícios da assistência judiciária, mediante simples afirmação, na própria petição inicial, de que não está em condições de pagar as custas do processo e os honorários de advogado, sem prejuízo próprio ou de sua família”, o que leva à conclusão de que o benefício pode ser requerido sem qualquer formalismo, bastando que o requerente afirme na petição inicial a sua situação de carência econômica. Já o artigo 6. ${ }^{\circ}$ da referida Lei determina:

O pedido, quando formulado no curso da ação, não a suspenderá, podendo o juiz, em face das provas, conceder ou denegar de plano o benefício de assistência. A petição, neste caso, será autuada em separado, apensando-se os respectivos autos aos da causa principal, depois de resolvido o incidente.

\footnotetext{
${ }^{257}$ JORGE, Mário Helton. Juízo (provisório) de admissibilidade da apelação. Isenção do preparo. Assistência judiciária gratuita. In: NERY JR., Nelson; WAMBIER, Teresa Arruda Alvim (Coord.). Aspectos polêmicos e atuais dos recursos cíveis de acordo com a Lei 10.352/2001. São Paulo: RT, 2001. v. 5, p. 427 e 422.
} 
Diante desses dois artigos, a conclusão a que se chega é de que, se o pedido de assistência judiciária é feito na própria petição inicial, bastando que o interessado o declare, e quando o requerimento é feito posteriormente, ou seja, no curso da ação, é necessária a produção de provas, e nesse caso a petição será autuada em apartado.

Embora o artigo 17 da Lei n. 1.060/1950 prescreva que “caberá apelação das decisões proferidas em consequência da aplicação desta Lei; a apelação será recebida somente no efeito devolutivo, quando a sentença conceder o pedido”, na realidade, o recurso cabível das decisões proferidas em virtude da aplicação da Lei n. ${ }^{0}$ 1.060/1950 dependerá da natureza da decisão que se busca impugnar.

Se a hipótese é de que a gratuidade da justiça é decidida nos próprios autos, por ter sido requerida pela parte na petição inicial, ou alegada pelo réu em contestação, trata-se de uma decisão interlocutória e o recurso cabível é o recurso de agravo. Não obstante, se a gratuidade da justiça é decidida em autos apartados, também aqui a impugnação é incidente ao processo principal e a decisão da questão incidental não extingue o processo que continua nos autos principais, e verifica-se que a natureza da decisão é interlocutória à semelhança das decisões que apreciam a impugnação ao valor da causa ou a exceção de incompetência. $^{258}$

Em ambos os casos entendemos que é inaplicável o artigo 17 da Lei n. ${ }^{\circ}$ 1060/1950 em razão de se tratar de um incidente processual, não podendo configurar como relação processual autônoma, sendo portanto cabível o recurso de agravo. ${ }^{259}$

A jurisprudência dominante, nessas hipóteses, é de que o recurso cabível é o de agravo, no entanto há julgados com o entendimento de que, se o pedido de assistência judiciária foi decidido em autos apartados, o recurso cabível é de apelação. ${ }^{260}$

Na prática, em tribunais estaduais, há decisões que admitem o requerimento de assistência judiciária no curso do processo, nos próprios autos, sem a necessidade de instaurar incidente à parte, o que, a princípio, fere o disposto no artigo $6 .^{\circ}$ da Lei

${ }^{258}$ DELLORE, Luiz Guilherme Pennachi. Do recurso cabível das decisões referentes à gratuidade da justiça (Lei 1060/1950). NERY JR., Nelson; WAMBIER, Teresa Arruda Alvim (Coord.), Aspectos polêmicos e atuais dos recursos cíveis e assuntos afins. São Paulo: R. dos Tribunais, v. 9, 2006, p. 330-331 e 335.

${ }_{259}$ Ibid., p. 333. Em sentido contrário, entendendo pela aplicabilidade do artigo 17 da Lei no 1060/1950. (JORGE, 2001, p. 422).

${ }^{260}$ AI 2051809-10.2014.8.26.0000, 6. ${ }^{a}$ Câmara Direito Privado, Rel. Ana Lucia Romanhole Martucci, j. 08.05.2014, cujo teor se infirma na não aplicação do princípio da fungibilidade que não se aplica diante de erro grosseiro. Agravo não conhecido. 
1.060/1950, gerando uma polêmica, visto que, se o pedido é feito na petição inicial ou nos próprios autos, a decisão sobre o seu acolhimento ou não é uma decisão interlocutória e o recurso cabível é o agravo de instrumento. Por sua vez, se o pedido de assistência judiciária feito no curso da ação é realizado conforme o artigo 6. ${ }^{\circ}$ da Lei 1.060/1950, em autos apartados, a decisão que resolve o incidente é sentença e o recurso cabível será a apelação.

Como já mencionamos, a situação que interessa a este estudo é o pedido feito no corpo das razões recursais, ou seja, quando o interessado recorre da sentença que lhe foi desfavorável e somente aí requer a assistência judiciária. Nesse caso, o juízo de admissibilidade do recurso poderá ser negativo ou positivo.

No Tribunal de Justiça do Estado de São Paulo, há julgado em que o recorrente requereu a assistência judiciária no corpo das razões recursais, e, ao ser indeferido o pedido, foi-lhe concedido prazo para efetuar o preparo, com a justificativa de não tratar-se de efeito retroativo, uma vez que o pedido da gratuidade é simultâneo à sua interposição, e, uma vez deferido, abarcará todos os atos posteriores, em especial sobre a sua admissibilidade e requisitos formais, visto que o contrário culminaria em verdadeira negativa de acesso ao Judiciário, uma vez que não poderia ser exigido da parte o recolhimento de valores supostamente incompatíveis com as suas condições financeiras. ${ }^{261}$

A jurisprudência majoritária do Superior Tribunal de Justiça demonstra que o entendimento daquela Corte é de que a assistência judiciária pode ser requerida a qualquer tempo, porém o pedido deve ser feito nos termos do artigo 6. ${ }^{\circ}$ da Lei 1.060/1950, em petição avulsa a ser autuada em apenso aos autos principais. No juízo de admissibilidade do recurso especial, por exemplo, consideram o recurso deserto quando o pedido de assistência é feito no seu corpo, justificando que a concessão do benefício não tem efeito retroativo e que no momento da oposição do recurso o recorrente não era beneficiário da justiça gratuita. $^{262}$

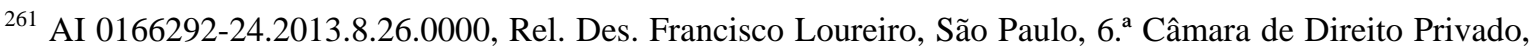
j. 19.09./2013, Reg. 21/09/2013; AI 0085477-74.2012.8.26.0000 Mogi das Cruzes, Rel. Manoel Mattos, 15. ${ }^{a}$ Câmara de Direito Privado, j. 19.03.2013, R. 20.03.2013.

${ }^{262}$ AgRg no AREsp 341225/RS 2013/0142400-4, Min. Mauro Campbell Marques, 2. ${ }^{a}$ Turma, DJe 11.08.2013; AgRg no AREsp 338536/SP 2013/0137366-2, Rel. Min. Nancy Andrighi, 3. a Turma, DJe 23.08.2013; AgRg no AREsp 334503/MA, 2013/0126527-3, Rel. Min. Antonio Carlos Ferreira, 4. ${ }^{\mathrm{a}}$ Turma, DJe 27.08.2013; AgRg no AREsp 228247/PR, 2012/0188197-6, Rel. Min. João Otávio de Noronha, 3. ${ }^{a}$ Turma, DJe 30.08.2013; AgRg no AREsp 314506/MS, 2013/0074044-0, Rel. Min. Raul Araújo, 4. ${ }^{\text {a } T u r m a, ~}$ DJe 01.08.2013; AgRg no AREsp 66453/MS, 2011/0249969-6, Rel. Min. Marco Buzzi, 4. ${ }^{a}$ Turma, j. 06.11.2012, DJe 13.11.2012; AgRg no Ag 1397200/PR, 2011/0019261-4, Rel. Min. Mauro Campbell Marques, 2. ${ }^{a}$ Turma, j. 23.08.2011, DJe 30.08.2011.
} 
No nosso sentir, se o ato de interposição do recurso é concomitante ao pedido de assistência judiciária, mesmo que seja feito no corpo das razões recursais, não deve obstar ao conhecimento do recurso com a justificativa de que a concessão da assistência judiciária não teria efeito retroativo, efetuando o juízo de admissibilidade negativo do recurso por ausência de preparo, pois, se o recorrente alega e prova que não tem condições financeiras de suportar as despesas processuais, negar-lhe conhecimento sumariamente seria coibir o seu acesso à justiça. Obviamente, se depois de uma análise mais aprofundada das provas da sua impossibilidade financeira ficar evidenciado que o recorrente pode arcar com as custas do processo sem prejuízo próprio e de sua família, deve ser indeferido tal pedido, porém deverá ser aberto prazo para que ele efetue o recolhimento das custas sob pena de deserção, pois negar-lhe conhecimento de plano evidencia excesso de formalismo, coibindo-lhe o acesso à justiça.

Nesse caso, a análise da questão no juízo de admissibilidade deve ser feita com a aplicação do artigo 244 do Código de Processo Civil, uma vez que o ato, ou seja, o pedido de assistência judiciária no corpo do recurso, alcançou a sua finalidade sem que tenha trazido prejuízo à outra parte, além disso, a forma prescrita na regra do artigo $6 .^{\circ}$ da Lei 1.060/1950 não prevê qualquer cominação de nulidade, se o pedido for realizado de forma diversa.

\subsection{Aspectos da admissibilidade dos recursos ordinários}

Os meios de impugnação constituem o remédio típico e quase único que provoca o controle da validade e justiça da decisão; constituem um desenvolvimento do direito de defesa constitucionalmente garantido. Como o direito de ação objetiva uma decisão de mérito sobre a existência ou inexistência de um direito, os meios de impugnação da sentença objetivam não somente eliminar a sentença inválida ou injusta, mas também substituí-la por outra sentença que se pronuncie sobre a existência ou não do direito acionado pelo autor. ${ }^{263}$

Dentre os recursos ordinários merecem relevo para os objetivos deste estudo: a apelação e o agravo.

${ }^{263}$ Ainda salienta Andrea Proto Pisani: "la notevole differenza della specie $<$ mezzi di impugnazione $>$ rispetto al genus <impugnazione> ricomprendente genericamente qualsiasi mezzo di attacco diretto alla eliminazione di un atto giuridico” (Diritto processuale civile. 3. ed. Napoli: Jovene, 1999. p. 482). 
A apelação é o recurso cabível contra toda e qualquer sentença, segundo a redação do artigo 162, § 1. ${ }^{\circ}$, do Código de Processo Civil: “o ato do juiz que implica algumas das situações previstas nos artigos 267 e 269”, não importando que o procedimento comum seja ordinário, sumário ou especial, como também não se distingue entre sentença definitiva e sentença meramente terminativa.

A apelação é o meio ordinário de impugnação contra sentença de primeiro grau, voltado fundamentalmente a provocar um reexame da causa de mérito, não limitado ao controle de vícios específicos, mas sim ao efeito devolutivo. ${ }^{264}$

A apelação devolverá ao tribunal o conhecimento da matéria impugnada e será apreciada nos limites especificados pelo próprio recorrente. Somente a matéria impugnada será objeto de apreciação em segunda instância, conforme prevê o artigo 515 do Código de Processo Civil que consagra o princípio tantum devolutum quantum appellatum. ${ }^{265}$

O recorrente, interessado em ver reformada a sentença que o prejudica, deverá indicar claramente os errores in judicando e/ou errores in procedendo que maculam a decisão, indicando em que ponto a decisão está errada e a necessidade de sua reforma. ${ }^{266}$

Renzo Provinciali demonstra que os recursos são compostos de dois elementos, um volitivo e outro de razão, correspondendo o primeiro à declaração de desagrado para com a sentença e o segundo, aos motivos que levam e conduzem à insatisfação existente com a sentença. ${ }^{267}$ Esses dois elementos formam, sem dúvida, o conteúdo do recurso de apelação.

A fundamentação do recurso tem o objetivo de demarcar a extensão do contraditório e “definir para a parte adversa e para o juízo o alcance e o sentido jurídico da impugnação levantada à sentença”268 ou seja, irá determinar o alcance da impugnação.

A ausência de fundamentação do recurso de apelação conduzirá à sua inadmissibilidade, pela falta de requisito essencial ao exame do seu mérito. Somente após preenchidos os requisitos da fundamentação e do pedido de nova decisão é que o órgão que irá julgar o recurso poderá analisar o mérito da apelação. ${ }^{269}$

\footnotetext{
${ }^{264}$ TARZIA, Giuseppe. Lineamenti del nuovo processo di cognizione. Milano: Giuffrè, 1996. p. 228.

${ }^{265}$ LUZ, Valdemar P. da. Manual dos recursos judiciais. 2. ed. São Paulo: Manole, 2007. p. 35.

${ }^{266}$ CHEIM JORGE, Flávio. Apelação cível: teoria geral e admissibilidade. São Paulo: RT, 2002. p. 189.

${ }^{267}$ PROVINCIALI, 1962. p. 213.

268 SEABRA FAGUNDES, M. Dos recursos ordinários em matéria civil. Rio de Janeiro: Forense, 1946. p. 102. No mesmo sentido: CHEIM JORGE, 2002, p. 190.

${ }^{269}$ Ibidem, p. 191.
} 
A partir do momento que o recurso de apelação é interposto, consuma-se o momento que deveria ser feito, ou seja, ocorre a preclusão que, segundo Flávio Cheim Jorge, é a espinha dorsal do processo, é um instituto aplicado como regra do direito processual, pois dele decorre a própria segurança jurídica. ${ }^{270}$

Para Eduardo Cambi, é possível analisar as regras que disciplinam o efeito devolutivo do recurso de apelação em sua extensão e profundidade. A extensão se refere ao inconformismo da parte vencida, ou seja, procura-se saber qual a matéria a ser examinada pelo órgão ad quem, tomando-se como parâmetro a decisão recorrida. O inconformismo pode ser: a) total, abrangendo tudo aquilo que foi apreciado pelo juiz de primeiro grau; b) pode ser parcial, quando compreende somente alguns dos capítulos da sentença; c) pode ocorrer oposição contra algum fundamento da ação ou da defesa que foi alegado, mas não foi apreciado pela sentença recorrida. A extensão corresponde ao princípio tantum devolutum quantum appellatum. Quanto a profundidade do efeito devolutivo, são transferidas ao órgão ad quem, além das questões apreciadas e julgadas pelo juiz de primeiro grau, tanto as matérias que podem ser examinadas ex officio, mesmo que não tenham sido debatidas no juízo a quo, por exemplo, a carência de ação, a falta de pressupostos processuais, as nulidades processuais absolutas etc., quanto aquelas que não foram julgadas na sentença, mas foram suscitadas e discutidas pelas partes no curso do processo. ${ }^{271}$ Concordamos com a posição do autor no que diz respeito à extensão, porém discordamos quanto à profundidade no que tange ao conhecimento das matérias que podem ser examinadas ex officio, pois entendemos que as matérias que não foram objeto do recurso transitaram em julgado e não poderão ser revistas pelo órgão ad quem.

A apelação tem por função precípua revisar os julgados de primeiro grau, mediante a intervenção de órgão judiciário de hierarquia superior, para reformar ou anular a sentença. $^{272}$

O recurso de apelação contra sentença definitiva, ou seja, aquela que tenha resolvido o mérito em primeiro grau de jurisdição, nem sempre visará à obtenção de um novo pronunciamento também sobre o mérito, ou seja, os seus fundamentos podem ser: a) alegações concernentes à invalidade da sentença, que por vícios que nela mesma se apontam, por exemplo, defeitos da sua estrutura formal, julgamento ultra petita ou extra

\footnotetext{
${ }^{270}$ CHEIM JORGE, 2002, p. 95.

${ }^{271}$ CAMBI, Eduardo, 2001. p. 238-240.

${ }^{272}$ ASSIS, 2008. p. 375.
} 
petita, ou por vícios que se apontam no processo e que são suscetíveis de afetar a decisão, como o impedimento do juiz, a incompetência absoluta, a não participação de litisconsórcio necessário, a não intimação do órgão do Ministério Público em caso de intervenção obrigatória; e b) alegações referentes à injustiça da sentença, em razão de erro cometido pelo juiz na solução de questões de fato por exemplo, passou despercebido um documento, interpretou-se erroneamente o depoimento de uma testemunha, deu-se crédito à outra não fidedigna, ou na solução de questões de direito, como entendeu-se aplicável norma jurídica impertinente à espécie, considerou-se vigente e lei que já não vigorava, ou inconstitucional a lei que não o era. ${ }^{273}$

O processamento da apelação no tribunal se dará por meio do registro, distribuição, designação do relator, revisor e terceiro juiz. A sessão de julgamento será designada pelo presidente do órgão fracionário (artigos 547, 548 e 552). No julgamento, tem precedência a matéria relativa à admissibilidade do recurso, arguida em preliminar (artigo 560), a qual, superada, ou seja, afastada a questão preliminar, passará o tribunal ao exame do mérito do recurso, ocasião em que o julgamento será realizado por todos os juízes que proferirão os seus votos (artigo 561). Na sessão de julgamento é permitida a sustentação oral das razões do recurso, tanto do advogado do recorrente quanto do advogado do recorrido (artigo 554). ${ }^{274}$

O recurso de apelação também é cabível contra sentenças que não contêm resolução do mérito, inclusive contra a que indefere a petição inicial.

Enrico Redenti ensina que a apelação é um meio de impugnação contra sentença de primeiro grau e é, sem dúvida, aquela mais utilizada. É uma invocação ao juiz de segundo grau, no sentido de solicitação de socorro, a fim de que reexamine, cancele ou repare defeitos ou erros de procedimento da sentença. ${ }^{275}$

Agravo é o recurso apto a impugnar as decisões interlocutórias, entendendo-se estas como: o ato pelo qual o juiz, no curso do procedimento, resolve uma questão incidente conforme artigo 162, § 2. ${ }^{\circ}$, do Código de Processo Civil. ${ }^{276}$ O processo continua a seguir o seu curso, em relação ao qual, necessariamente, se reflete a eficácia de tais decisões, daí a inegável relevância dos atos em espécie, sobretudo daqueles que causam ou possam causar

\footnotetext{
${ }^{273}$ BARBOSA MOREIRA, 2010. item 134, p. 418-419.

274 WAMBIER, Luiz Rodrigues; ALMEIDA, Flávio Renato Correia de; TALAMINI, Eduardo. Curso avançado de processo civil. 6. Ed. São Paulo: RT, 2003. v. 1, p. 594-595.

${ }^{275}$ REDENTI, 1997, p. 443.

${ }^{276}$ MIRANDA, Gilson Delgado; PIZZOL, Patrícia Miranda. Recursos no processo civil. 5. Ed. São Paulo: Atlas, 2008, p. 75.
} 
às partes alguma lesão não corrigível depois, nem pela sentença definitiva, nem pela via recursal. ${ }^{277}$

As decisões interlocutórias são recorríveis por meio do recurso de agravo, e o nosso Código de Processo Civil a desdobrou em duas modalidades, sendo uma denominada “retido” e outra, “de instrumento”. Tanto o agravo retido quanto o agravo de instrumento destinam-se a evitar a preclusão das decisões interlocutórias, buscando sua mediata (retido) ou a sua imediata (de instrumento) reforma ou modificação. ${ }^{278}$

Com as reformas ocorridas com a Lei n. ${ }^{\circ} 10.352 / 2001$ e n. ${ }^{\circ} 11.187 / 2005$ as decisões interlocutórias passaram a comportar reexame por agravo na forma retida e apenas excepcionalmente é que o agravo pode ser interposto por instrumento. ${ }^{279}$

Os casos de agravo retido são definidos pelo artigo 522 do Código de Processo Civil, por exclusão, ou seja, será retido o agravo interposto de qualquer decisão interlocutória que não seja suscetível de causar à parte lesão grave e de difícil reparação, bem como nos casos de inadmissão da apelação e nos relativos aos efeitos em que a apelação é recebida, quando será admitida a sua interposição por instrumento.

Por lesão grave e de difícil reparação deve-se entender aquela que, no caso concreto, exige imediata reforma, como condição de idoneidade do provimento aguardado. $^{280}$ A decisão deverá ser controlada imediatamente pelo tribunal, sob pena de esvaziar-se o objetivo do recurso, causando perda do interesse recursal, ou seja, ocorrerá lesão sempre que o caso exigir manifestação breve do juízo ad quem, embora não seja um caso de urgência. ${ }^{281}$

O procedimento do recurso de agravo no segundo grau de jurisdição corresponde ao recebimento do recurso pelo relator, podendo este requisitar informações ao juiz que proferiu a decisão recorrida. Necessariamente o agravado será intimado, com oportunidade de manifestar-se, apresentando as suas contrarrazões. Se houver requerimento da parte e se estiverem preenchidos os demais pressupostos, poderá o relator imprimir efeito suspensivo

\footnotetext{
${ }^{277}$ LUZ, 2007, p. 47.

${ }^{278}$ CARREIRA ALVIM, J.E.; CABRAL, Luciana Gontijo Carreira Alvim. Nova mexida nos agravos retido e de instrumento. In: NERY JR., Nelson; WAMBIER, Teresa Arruda Alvim (Coord.). Aspectos polêmicos e atuais dos recursos cíveis e assuntos afins. São Paulo: RT, 2007. v. 9, p. 279.

${ }^{279}$ BUENO, Cassio Scarpinela. A nova etapa da reforma do Código de Processo Civil. 2. ed. São Paulo: Saraiva, 2006. v. 1, p. 239-240.

${ }^{280}$ AZEM, Guilherme Beux Nassif. A nova disciplina do agravo. In: NERY JR., Nelson; WAMBIER, Teresa Arruda Alvim (Coord.). Aspectos polêmicos e atuais dos recursos cíveis e assuntos afins. São Paulo: RT, 2007. v. 11, p. 105.

${ }^{281}$ CARNEIRO DA CUNHA, Leonardo José. Evoluções e involuções do agravo. In: NERY JR., Nelson; WAMBIER, Teresa Arruda Alvim (Coord Aspectos polêmicos e atuais dos recursos cíveis e assuntos afins. São Paulo: RT, 2007. v. 9, p. 307).
} 
ao recurso de agravo, o que significa determinar que a decisão recorrida não produza efeitos enquanto não houver o julgamento do agravo. ${ }^{282}$

O regime de recorribilidade das interlocutórias traz consigo um sistema rígido de preclusões, que estabiliza as decisões tomadas incidentalmente, o que as torna irrevogáveis pelo juiz que as proferiu, salvo algumas exceções. Se contra uma determinada decisão interlocutória não for interposto recurso ou se for rejeitado, a decisão torna-se imune de ataques das partes e de revogação pelo magistrado que a prolatou, o que privilegia o princípio da segurança jurídica. ${ }^{283}$

De maneira diversa dos demais recursos, o agravo de instrumento deve ser proposto, conforme determina o artigo 524 do Código de Processo Civil diretamente ao tribunal competente.

A petição deverá cumprir os requisitos de formação do instrumento que são: a) a exposição do fato e do direito; b) as razões do pedido de reforma da decisão; e c) o nome e o endereço completo dos advogados, constantes do processo, bem como deverá estar acompanhada, obrigatoriamente, com as cópias da decisão agravada, da certidão da respectiva intimação e das procurações outorgadas aos advogados do agravante e do agravado, devendo também acompanhá-la o comprovante de pagamento das respectivas custas e do porte de remessa e retorno.

Ao receber o recurso de agravo de instrumento, o relator, ao examiná-lo, poderá assumir uma das seguintes posturas: a) negar-lhe seguimento, liminarmente, nos casos do artigo 557, I, do Código de Processo Civil; b) converter o agravo de instrumento em agravo retido, salvo quando se tratar de decisão suscetível de causar à parte lesão grave e de difícil reparação, bem como nos casos de inadmissão da apelação e nos relativos aos efeitos em que a apelação é recebida, mandando remeter os autos ao juiz da causa, conforme artigo 557, II, do mesmo diploma legal; nestes casos estará efetuando o juízo negativo de admissibilidade.

Ao constatar formação deficiente do instrumento, quando tiver sido interposto fora do prazo legal ou contra despacho ordinatório, ou seja, sempre que não estiverem presentes

\footnotetext{
${ }^{282}$ WAMBIER; ALMEIDA et TALAMINI, 2003, p. 606.

283 SICA, Heitor Vitor Mendonça. Recorribilidade das interlocutórias e reformas processuais: novos horizontes do agravo retido. In: NERY JR., Nelson; WAMBIER, Teresa Arruda Alvim (Coord.). Aspectos polêmicos e atuais dos recursos cíveis. São Paulo: RT, 2005. v. 8, p. 169 e 171.
} 
os pressupostos de admissibilidade do recurso, este será considerado inadmissível pelo relator. $^{284}$

Cândido Rangel Dinamarco exemplifica a negativa de seguimento ao agravo com fundamento na inadmissibilidade quando o agravo for interposto além dos dez dias subsequentes à decisão proferida pelo juiz de primeiro grau, o que ocorre quando a parte requer reconsideração e o juiz nega, conforme jurisprudência do Superior Tribunal de Justiça, no sentido de que os pedidos de reconsideração não reabrem nem dilatam prazos para recorrer. No entanto, se a pretensão recursal estiver em desacordo com súmula ou jurisprudência, a decisão será de improcedência e, portanto, será uma decisão de mérito. ${ }^{285}$ No primeiro exemplo, a decisão é do juízo de admissibilidade do recurso, enquanto no segundo caso é do juízo de mérito.

Quanto ao preparo do agravo, a dicção do $\S 1 .^{\circ}$ do artigo 525 do Código de Processo Civil não reproduz com a mesma clareza o que prescreve o artigo 511 do mesmo diploma legal quanto ao momento de efetivação do preparo dos recursos em geral. Pela dicção legal, a indispensabilidade do preparo passou de condição de admissibilidade a pressuposto à sua interposição. No entender de Maria Berenice Dias, há que se recorrer do princípio da preclusão consumativa, segundo o qual, protocolizado o recurso, preclui para a parte a possibilidade de prepará-lo ou de juntar documentos, ficando o agravante impossibilitado de eventual complementação. ${ }^{286}$

Há casos no processo de conhecimento em que é admissível somente o agravo de instrumento, independentemente de que possa sobrevir, ou não, lesão grave e de difícil reparação, por exemplo, quando a decisão venha a influir subjetivamente em algum polo da demanda. Assim, se o juiz não admitir reconvenção, o reconvinte não encontrará utilidade processual alguma no uso do agravo retido, pois seu objetivo é a concomitância da ação e da reconvenção. Outro exemplo ocorre quando o juiz não admite a intervenção de um terceiro (assistente), pois nada adiantará ao terceiro uma assistência deferida na esfera recursal, com a lide já julgada. ${ }^{287}$

A atual redação do inciso II do artigo 527 do Código de Processo Civil impõe ao relator a obrigatoriedade da conversão do recurso de agravo em retido, nos casos em que

\footnotetext{
${ }^{284}$ BRUSCHI, Gilberto Gomes; NOTARIANO JR., Antonio. Agravo contra as decisões de primeiro grau. São Paulo: Método, 2006. p. 44.

${ }^{285}$ DINAMARCO, Cândido Rangel. A reforma da reforma. 3. Ed. São Paulo: Malheiros, 2002b, p. 188.

${ }^{286}$ DIAS, Maria Berenice. Agravo: alguns pontos controvertidos. Revista de Processo. São Paulo, ano 23, n. 92, p. 236-237, out.-dez. 1998. .

287 CARNEIRO, Athos Gusmão. Do recurso de agravo ante a Lei 11.187/2005. Revista Jurídica. Porto Alegre, ano 54, n. 339, jan. 2005.
} 
não haja lesão grave e de difícil reparação, o que anteriormente era uma faculdade. Dessa forma, diante de um agravo de instrumento que não se enquadre em uma das três hipóteses previstas no caput do artigo 522, o relator deverá convertê-lo em agravo retido. ${ }^{288}$

\subsection{Aspectos da admissibilidade dos recursos excepcionais}

O recurso especial e o recurso extraordinário possuem uma natureza que lhes é particular e características próprias que os distinguem dos recursos ordinários. Destacamse dos demais recursos porque se constituem de instrumentos destinados à preservação da adequada aplicação e interpretação de leis federais ou da Constituição Federal.

Quanto aos requisitos de admissibilidade, além de todos os requisitos gerais acima enumerados no item 4.4, os requisitos específicos são extraídos do próprio texto constitucional.

O recurso especial deve ser interposto perante o Superior Tribunal de Justiça, sendo cabível, nos termos do artigo 105, III, da Constituição Federal, contra as decisões que: a) contrariarem tratado ou lei federal, ou negarem-lhes a vigência; b) julgarem válido ato de governo local contestado em face de lei federal; c) derem à lei federal interpretação divergente da que lhe haja atribuído outro tribunal. O recurso deve ser direcionado exclusivamente contra decisão do Tribunal Regional Federal e Tribunal de Justiça Estadual, do Distrito Federal e Territórios, devendo ter sido proferida em única ou última instância, além do que deve ser invocada questão federal, nos termos constitucionais. ${ }^{289}$

Com base na alínea “a” do artigo 105, III, retrodescrito, a jurisprudência do Superior Tribunal de Justiça tem entendido que para ter cabimento o recurso especial é necessário demonstrar de forma inequívoca e frontal a violação ao texto infraconstitucional, e não de maneira implícita. A matéria em questão diz respeito ao “cabimento” do recurso que afeta o juízo de admissibilidade. Não sendo cabível, o recurso interposto não será conhecido e o seu mérito não será analisado. No entanto, se a jurisprudência do Superior Tribunal de Justiça exige que se demonstre, de forma

${ }^{288}$ SCHWIND, Rafael Wallbach. O regime do recurso de agravo com as alterações da Lei 11.187/2005. In: MEDINA et al. (Coord.). Os poderes do juiz e o controle das decisões judiciais. Estudos em homenagem à Professora Teresa Arruda Alvim Wambier. São Paulo: RT, 2008. p. 828.

${ }^{289}$ LUZ, 2007. p. 100. 
inequívoca e frontal, a violação da lei federal, uma vez revelada essa violação, o resultado do julgamento deverá ser o de "provimento" do recurso. O inverso, ou seja, caso o tribunal verifique não ter ocorrido a violação à lei infraconstitucional, o resultado deverá ser o oposto, ou seja, o “não provimento” do recurso especial. Não obstante, a solução preconizada pelo Superior Tribunal de Justiça é no sentido do “não conhecimento” do recurso. No entendimento de José Miguel Garcia Medina, sempre que o tribunal perquirir, de modo suficiente a questão, a ponto de verificar se houve ou não violação ao texto infraconstitucional ou constitucional, conforme o caso, não estará realizando juízo de admissibilidade, mas, sim, de mérito. Portanto, deverá dar ou negar provimento ao recurso. $^{290}$

A questão federal há de ser prequestionada, ou seja, é necessário que o tribunal $a$ quo a tenha apreciado, o que torna o prequestionamento um dos pressupostos de admissibilidade do recurso especial. A regra do prequestionamento ajusta-se ao princípio da eventualidade, segundo o qual as partes devem suscitar desde logo todas as questões a serem objeto de decisão. ${ }^{291}$

O recurso extraordinário deve ser interposto perante o Supremo Tribunal Federal para atacar decisões proferidas por outros tribunais, nos casos expressamente previstos no artigo 102, III, da Constituição Federal, ou seja: a) decisão que contrariar dispositivo da Constituição; b) decisão que declarar a inconstitucionalidade de tratado ou lei federal; c) decisão que julgar válida lei ou ato de governo local contestado em face da Constituição; d) decisão que julgar válida lei local contestada em face de lei federal. ${ }^{292}$

A função do Supremo Tribunal Federal, ao julgar o recurso extraordinário, não é resolver litígios entre as partes, tampouco revisar todos os pronunciamentos dos tribunais inferiores. O processo existente entre as partes trazido ao tribunal superior deve ser visto

\footnotetext{
290 MEDINA, José Miguel Garcia. O prequestionamento nos recursos extraordinário e especial. 3. ed. São Paulo: RT, 2002. p. 143-144. (Recursos no processo civil, v. 6.)

${ }^{291}$ RIBEIRO, Antônio de Pádua. Do recurso especial para o Superior Tribunal de Justiça. In: TEIXEIRA, Sálvio de Figueiredo (Coord.). Recursos no Superior Tribunal de Justiça. São Paulo: Saraiva, 1991. p. 54. Salienta Francisco Cláudio de Almeida Santos que a ideia do prequestionamento tem sua origem na Lei Judiciária (Judiciary Act) norte-americana que admitiu das decisões da justiça estadual recurso para a Corte Suprema, recurso que recebeu o nome de writ of error. A doutrina prevalente nos Estados Unidos é que a questão federal tenha sido suscitada e resolvida pelo Tribunal do Estado (Recurso especial - visão geral. In: TEIXEIRA, Sálvio de Figueiredo (Coord.). Recursos no Superior Tribunal de Justiça. São Paulo: Saraiva, 1991. p. 103-104). No mesmo sentido: CARNEIRO, Athos Gusmão. Anotações sobre o recurso especial. In: ----- (Coord.). Recursos no Superior Tribunal de Justiça. São Paulo: Saraiva, 1991. p. 112.

${ }^{292}$ LUZ, 2007. p. 112.
} 
apenas como pressuposto para uma atividade jurisdicional que transcende os interesses subjetivos. $^{293}$

Para a admissibilidade do recurso extraordinário é necessário o atendimento do requisito denominado prequestionamento, conforme Súmula 282 do Supremo Tribunal Federal: “É inadmissível o recurso extraordinário quando não ventilada, na decisão recorrida, a questão federal suscitada”. Ou seja, o prequestionamento ocorre quando a questão federal foi devidamente suscitada e defendida nas instâncias ordinárias. ${ }^{294}$

Quase no mesmo sentido, a Súmula 356 do Supremo Tribunal Federal dispõe que, se não constar da decisão de que se quer recorrer o "ponto” relativo ao que seria o mérito do recurso extraordinário ou do recurso especial, o recorrente deverá interpor embargos declaratórios para que tal “ponto” esteja disposto na decisão. ${ }^{295}$

Esclarece Teresa Arruda Alvim Wambier “que a exigência do prequestionamento decorre da circunstância de os recursos especial e extraordinário serem recursos de revisão. Revisa-se o que já se decidiu”. E prossegue: “Trata-se, na verdade, de recursos que reformam as decisões impugnadas em princípio, com base no que consta das próprias decisões impugnadas”. 296

Para o manuseio do recurso especial é necessário que na decisão impugnada conste a matéria federal controvertida, de modo que se entenda por prequestionada e atendida a exigência específica dos recursos excepcionais, os quais se destinam a rever o que já foi decidido. Em outras palavras, o que importa é que a matéria tenha sido discutida e apreciada na instância inferior. ${ }^{297}$

No que diz respeito ao juízo de admissibilidade do recurso extraordinário e do recurso especial, ocorre um fenômeno típico dos recursos de fundamentação vinculada que consiste na possibilidade de que haja certa dose de sobreposição entre o juízo de admissibilidade e o juízo de mérito. Os artigos 102, III, e 105, III, da Constituição Federal demonstram que os únicos fundamentos possíveis desses recursos são a ocorrência de

\footnotetext{
${ }^{293}$ DIDIER JR., Fredie. O recurso extraordinário e a transformação do controle difuso de constitucionalidade no direito brasileiro. In: OLIVEIRA et al. (Coord.). Recursos e a duração razoável do processo. Brasília: Gazeta Jurídica, 2013. p. 235.

${ }^{294}$ LUZ, 2007. p. 112-113.

295 WAMBIER, ALMEIDA et TALAMINI, 2003, p. 637.

${ }^{296}$ WAMBIER, Teresa Arruda Alvim. Recurso especial, recurso extraordinário e ação rescisória. 2. ed. São Paulo: RT, 2008. p. 401.

${ }^{297}$ CHEIM JORGE, Flávio; SANTANA, Felipe Teles. Uma análise crítica sobre o recurso especial e o conhecimento das matérias de ordem pública. Revista de processo. São Paulo: R. dos Tribunais, Ano 37. V. 213, 2012, p. 342.
} 
ofensa à Constituição Federal e a ofensa a lei federal, e na primeira hipótese a ofensa deverá ainda apresentar repercussão geral. ${ }^{298}$

Na opinião de Teresa Arruda Alvim Wambier, poderiam os enunciados levar a crer que, se um recurso extraordinário ou um recurso especial fossem admitidos, estes sempre deveriam ser julgados providos, uma vez que previamente se teriam considerado tais ofensas ao se admitirem os recursos. Entretanto, não é assim que ocorre. Para a processualista, o juízo de admissibilidade negativo de um recurso de fundamentação vinculada, no sentido em que se afirma não haver ofensa à lei, é decisão baseada em certeza, com cognição exauriente pela obviedade da situação configurada no caso concreto, cujo objeto é, sem sombra de dúvidas, o mérito recursal. Se, por exemplo, se tratar de uma decisão que declara a integral inviabilidade do recurso interposto é pelo fato de se ter apontado na petição de interposição ofensa a direito municipal. ${ }^{299}$

Argumenta, ainda, a processualista que, quando se trata de recursos de fundamentação vinculada, o juízo de inadmissibilidade é, muito frequentemente, um juízo de não provimento do recurso, proferido como resultado de uma cognição exauriente (certeza) quanto à inexistência do fundamento invocado na decisão. Quando é feito o juízo negativo de admissibilidade. Esse o juízo de inadmissibilidade é um juízo definitivo, de certeza quanto à inviabilidade do provimento do recurso, muitas vezes por razões de mérito. Quando o juízo de admissibilidade é positivo, envolve sempre um juízo de viabilidade-possibilidade de que se dará provimento àquele recurso. ${ }^{300}$

No que diz respeito aos requisitos de admissibilidade dos recursos extraordinário e especial, constam nos Regimentos Internos do Supremo Tribunal Federal e Tribunal Superior de Justiça disposições acerca do procedimento e forma específica de interposição desses recursos, preenchendo lacunas da lei conforme preceituam a Lei de Orgânica da Magistratura e o Código de Processo Civil, com observância das normas processuais e garantias constitucionais. $^{301}$

\footnotetext{
${ }^{298}$ WAMBIER, 2008. p. 248.

${ }^{299}$ Ibidem.

${ }^{300}$ Ibidem, p. 249.

${ }^{301}$ Observa-se que a Constituição Federal não autoriza os Regimentos Internos dos Tribunais de superposição a estatuírem óbices regimentais que restrinjam o cabimento dos recursos extraordinário e especial (MAGRI, Berenice Soubhie Nogueira. O papel decisivo dos regimentos internos do Supremo Tribunal Federal e do Superior Tribunal de Justiça na admissibilidade dos recursos extraordinário e especial. In: WAMBIER, Teresa Arruda Alvim (Coord.). Aspectos polêmicos e atuais do recurso especial e recurso extraordinário. São Paulo: RT, 1997. p. 92-93).
} 
Os artigos 102, III, e 105, III, da Constituição Federal se referem a causas decididas em única ou última instância. Doutrinariamente, o vocábulo “causa” vem sendo entendido em seu sentido amplo, tanto para as decisões terminativas quanto para as decisões de mérito, e, conforme ensina Rodolfo de Camargo Mancuso, os recursos extraordinário e especial versam sobre questões constitucionais e federais, respectivamente, exigindo-se que tenham sido exercitados os recursos ordinários cabíveis, não importando a qualidade da decisão, se definitiva ou terminativa, ${ }^{302}$ ou seja, independentemente de se tratar de mérito ou não, como não se faz ligação a concepção de justiça da decisão à natureza dos recursos extraordinário e especial, não faz sentido conceber tais recursos como circunscritos às decisões que versarem sobre o mérito.

Quanto aos efeitos do juízo de admissibilidade pelo órgão ad quem, se for positivo, o órgão destinatário do recurso estará reconhecendo e assumindo o poder-dever de decidir o seu mérito, ou seja, deverá decidir sobre a existência ou inexistência do defeito no ato judicial apontado pelo recorrente. Caso o juízo de admissibilidade seja negativo, o efeito programado é o encerramento do procedimento recursal, sem que o mérito seja apreciado, ou seja, sem que o órgão julgador se pronuncie sobre o acerto ou erro da decisão recorrida. Esse efeito pode, no entanto, ser obstado pela interposição de outro recurso eventualmente cabível, conforme a situação, a saber: a) embargos infringentes; b) recurso especial; c) agravo interno. ${ }^{303}$

O filtro para a admissibilidade dos recursos excepcionais, se comparado com os demais, é muito mais rigoroso e com nuances que os particularizam. Como se trata de recursos dirigidos aos tribunais superiores que visam resguardar a aplicação das leis federais e da Constituição Federal, não poderiam possuir largo espectro de abrangência, pois, se assim o fosse, os tribunais superiores assumiriam uma posição de terceira instância. $^{304}$

Os recursos excepcionais têm como objetivo principal a ofensa à legislação constitucional e infraconstitucional e a uniformização jurisprudencial. Esses permissivos sobre o cabimento desses recursos deixam clara a intenção de corrigir eventuais

${ }^{302}$ MANCUSO, 2012. p. 133. No mesmo sentido: MEDINA, José Miguel Garcia. O prequestionamento e os pressupostos dos recursos extraordinário e especial. In: WAMBIER, Teresa Arruda Alvim (Coord.). Aspectos polêmicos e atuais do recurso especial e recurso extraordinário. São Paulo: RT, 1997. p. 253254.

303 MEDINA, ibidem, p. 253-254.

${ }^{304}$ FRANÇOLIN, Wanessa de Cássia. O juízo de admissibilidade dos recursos especial e extraordinário exercido pelo Tribunal local. In: NERY JR., Nelson; WAMBIER, Teresa Arruda Alvim (Coord.). Aspectos polêmicos e atuais dos recursos cíveis. São Paulo: RT, 2006. v. 9, p. 652. 
desrespeitos legais e jurisprudenciais por parte das decisões recorridas dos tribunais inferiores. Para a verificação do cabimento da decisão recorrida, ou seja, se ela se enquadra em alguma das hipóteses cuja matéria já tenha sido apreciada, necessária a exigência do prequestionamento, que neste caso não é mero formalismo, mas exigência constitucional. $^{305}$

Quando o recurso especial ou extraordinário é interposto contra decisão interlocutória proferida em processo de conhecimento, cautelar ou de execução, ele ficará retido nos autos, e somente será processado se o recorrente o reiterar no prazo destinado à interposição de recurso contra a decisão final, ou para a apresentação das contrarrazões, conforme prescreve o artigo 542, § 3. ${ }^{\circ}$, do Código de Processo Civil. Caso a parte interessada entenda tratar-se de matéria de extrema urgência, será viável a utilização de agravo de instrumento, nos termos do artigo 544 do Código de Processo Civil para assegurar o seguimento do recurso. ${ }^{306}$

No que concerne ao requisito preparo, o artigo 112 do Regimento Interno do Superior Tribunal de Justiça estatui que não são devidas custas nos processos de competência originária ou recursal do Superior Tribunal de Justiça, porém nem por essa razão deixa de ser devido o porte de remessa e retorno, que se inclui no conceito mais abrangente de preparo, devendo o recorrente comprovar o seu recolhimento no ato de interposição do recurso especial. ${ }^{307}$

O § 3. ${ }^{\circ}$ do artigo 102 da Constituição Federal prescreve: "No recurso extraordinário o recorrente deverá demonstrar a repercussão geral das questões constitucionais discutidas no caso, nos termos da lei, a fim de que o Tribunal examine a admissão do recurso, somente podendo recusá-lo pela manifestação de dois terços de seus membros”, cuja lei regulamentadora passou a viger em 18.02.2007.

A criação do requisito da repercussão geral constitui uma tentativa de confinar o recurso extraordinário aos seus fins originários, devolvendo ao Supremo Tribunal Federal a

${ }^{305}$ CÔRTES, Osmar Mendes Paixão. As nulidades acolhidas pelos tribunais superiores em recursos de natureza extraordinária - necessidade ou formalismo? In: MEDINA et al. (Coord.). Os poderes do juiz e o controle das decisões judiciais. Estudos em homenagem à Professora Teresa Arruda Alvim Wambier. São Paulo: RT, 2008. p. 981.

${ }^{306}$ BARBOSA MOREIRA, 2010. item 134, p. 610-611. No mesmo sentido: ARAÚJO, Fábio Caldas. Breves considerações sobre o agravo (instrumento e retido). In: MEDINA et al. (Coord.). Os poderes do juiz e o controle das decisões judiciais. Estudos em homenagem à Professora Teresa Arruda Alvim Wambier. São Paulo: RT, 2008. p. 688.

${ }^{307}$ ARRUDA ALVIM, Eduardo. Recurso especial e recurso extraordinário. In: NERY JR., Nelson; WAMBIER, Teresa Arruda Alvim (Coord.). Aspectos polêmicos e atuais dos recursos cíveis de acordo com a Lei 10.352/2001. São Paulo: RT, v. 5, 2002. p. 163. 
autodeterminação em relação à sua tarefa de última instância do controle difuso de constitucionalidade. $^{308}$

O legislador, ao elaborar o $\S 3 .^{\circ}$ do artigo 102 da Carta Magna, introduzindo a exigência da repercussão geral da questão constitucional, valeu-se de conceito vago, pois não se vê no dispositivo qualquer indicação das hipóteses em que se reputará presente a repercussão geral. O dispositivo concede maior liberdade de atuação do julgador na aplicação da norma, permitindo-lhe analisar o caso concreto e avaliar a presença do novo requisito, incluindo situações novas que talvez não tivessem sido idealizadas pelo legislador. $^{309}$ Dessa forma, a norma permite que o aplicador do direito amplie o entendimento daquilo que entende que tenha repercussão geral.

Para a análise da repercussão geral, pressupõe-se a participação colegiada dos membros do Supremo Tribunal Federal. Isso se verifica tanto no texto constitucional ao exigir a votação de dois terços dos ministros da Corte para a rejeição do recurso extraordinário por falta de repercussão geral quanto na lei regulamentadora que determina que é dispensada a remessa ao plenário quando, no exame da turma, quatro ministros concordarem que o pressuposto está presente. Uma vez que o pressuposto da repercussão geral foi instituído por norma cogente, o Supremo Tribunal Federal não pode deixar de examinar o recurso extraordinário que discuta questões constitucionais revestidas de repercussão geral, tampouco pode examinar o recurso desprovido desse pressuposto. ${ }^{310}$

Os recursos passam por uma filtragem realizada pelo juízo de admissibilidade, em que serão analisadas as questões processuais atinentes ao recurso, para posteriormente, se admitidos, serem analisados quanto ao mérito. Normalmente, o cumprimento dos requisitos para a admissibilidade dos recursos é ônus da parte interessada na reforma da decisão e/ou de seu procurador.

\footnotetext{
${ }^{308}$ Nesse sentido, Elton Venturi salienta que o STF disciplina o conhecimento ou a inadmissão do recurso extremo levando em conta fatores extraprocessuais (repercussão política, social ou econômica) das questões suscitadas (Anotações sobre a repercussão geral como pressuposto de admissibilidade do recurso extraordinário. In: MEDINA et al. (Coord.). Os poderes do juiz e o controle das decisões judiciais. Estudos em homenagem à Professora Teresa Arruda Alvim Wambier. São Paulo: RT, 2008. p. 912).

${ }^{309}$ FERNANDES, Luís Eduardo Simardi. A irrecorribilidade da decisão que não conhece do recurso extraordinário por ausência da repercussão geral. In: MEDINA et al. (Coord.). Os poderes do juiz e o controle das decisões judiciais. Estudos em homenagem à Professora Teresa Arruda Alvim Wambier. São Paulo: RT, 2008. p. 944.

${ }^{310}$ NASCIMENTO, Bruno Dantas. O recurso extraordinário e a Lei 11.418/2006: notas sobre a dinâmica da repercussão geral. In: MEDINA et al. (Coord.). Os poderes do juiz e o controle das decisões judiciais. Estudos em homenagem à Professora Teresa Arruda Alvim Wambier. São Paulo: RT, 2008. p. 880.
} 
Essa regra, no entanto, não é válida para os recursos excepcionais (extraordinário e especial), haja vista a imensa dificuldade em que esses recursos passem pelo juízo de admissibilidade e recebam uma decisão de mérito, exatamente porque há requisitos formais que não dependem apenas da parte interessada e/ou de seu procurador para se configurarem, consubstanciados em importante mecanismo limitador ao direito de recorrer, tais como súmulas impeditivas de recursos, como prescreve o $\S 11^{\circ}$ do artigo 518 do Código de Processo Civil, que dispõe: ”O juiz não receberá o recurso de apelação quando a sentença estiver em conformidade com súmula do Superior Tribunal de Justiça ou do Supremo Tribunal Federal”. Outro requisito que não depende da parte é a exigência do prequestionamento, uma vez que ela pode requerer o prequestionamento quando se dirige ao tribunal em suas razões ou contrarrazões de apelação, agravo de instrumento ou retido, ou nas exceções de impedimento ou suspeição, porém caberá ao tribunal manifestar-se expressamente sobre a questão de direito constitucional ou infraconstitucional. ${ }^{311} \mathrm{O}$ Superior Tribunal de Justiça já decidiu: “para que se configure o prequestionamento da matéria, há que se extrair do acórdão recorrido deliberação sobre as teses jurídicas em torno dos dispositivos legais tidos como violados, a fim de que se possa, na instância especial, abrir discussão sobre determinada questão de direito, definindo-se, por conseguinte, a correta interpretação da legislação federal”. 312

Quando o Supremo Tribunal Federal não conhecer do recurso extraordinário, por entender que a questão constitucional nele versada não oferece repercussão geral, essa decisão é irrecorrível, conforme prescreve o artigo 543-A do Código de Processo Civil.

\footnotetext{
${ }^{311}$ NOGUEIRA, Gustavo Santana. A repercussão geral do recurso extraordinário e a Emenda Regimental 21/2007 do STF - uma proposta de interpretação da análise deste novo requisito de admissibilidade. In: MEDINA et al. (Coord.). Os poderes do juiz e o controle das decisões judiciais. Estudos em homenagem à Professora Teresa Arruda Alvim Wambier. São Paulo: RT, 2008. p. 918-919.

${ }^{312}$ ArRg no AgRg no REsp 845532/PR, 2. ${ }^{a}$ T. Rel. Min. Eliana Calmon, DJ 22.03.2007. Decisões semelhantes estão sendo proferidas reiteradamente.
} 


\section{FORMA E FORMALISMO NO ÂMBITO RECURSAL}

\subsection{Forma e formalismo}

Nas diferentes áreas do conhecimento, como na história do direito, na sociologia do direito, na filosofia do direito, no direito comparado e no estudo cultural do direito, além do campo interdisciplinar denominado “teoria do direito”, o “formalismo jurídico” é utilizado em diferentes sentidos. São duas as mais importantes dimensões do formalismo: a) persistência da conformidade com as formalidades (que exceções são permitidas?) e b) grau de absolutismo da sanção de nulidade pelo fracasso no cumprimento de tais formalidades (que remédios existem, se é que existe algum, para aqueles que falham no cumprimento das formalidades?). O grau de formalismo em cada dimensão varia no tempo e entre os sistemas. O que une os diferentes tipos de dimensões é a boa vontade do formalista em sacrificar a justiça substantiva, ou equidade, no caso particular. ${ }^{313}$

O uso descritivo do formalismo jurídico se refere a um leque de técnicas de interpretação jurídica baseada no significado das normas. O uso textual interpretativo decide pela identificação da norma válida aplicável ao caso. Já o formalismo interpretativo conceitual constrói princípios gerais necessários para que um sistema jurídico seja entendido coerentemente, utiliza os princípios para resolver a incerteza sobre o significado das normas jurídicas válidas e os aplica de acordo com o seu significado para preencher lacunas aparentes. $\mathrm{O}$ formalismo interpretativo de precedentes interpreta de acordo com o significado das normas derivadas de decisões judiciais concedidas em casos anteriores. A interpretação plena requer efetivamente que o intérprete aplique em cada caso as normas jurídicas que possa obter da análise do texto ou de precedentes. ${ }^{314}$

Não se deve esquecer que a tarefa central de um sistema jurídico é encontrar maneiras de resolver conflitos que inevitavelmente surgem em comunidades humanas. As

313 KENNEDY, Duncan. Formalismo jurídico. Tradução de Sheila Stolz. In: RODRIGUEZ, José Rodrigo (Org.). A justificação do formalismo jurídico. São Paulo: Saraiva, 2011. p 15-16.

314 Idem, ibidem, p 16-17. 
categorias jurídicas se modificam e se adaptam na busca de resoluções sustentáveis para os conflitos diante de circunstâncias sociais em permanente mutação. ${ }^{315}$

Larry Alexander define formalismo "como a aderência à prescrição de uma norma sem atenção às regras de fundo às quais a norma deve servir (mesmo quando a prescrição da norma não atende àquelas razões em um caso particular”. ${ }^{316}$ Em outras palavras, ocorre quando um formalista visa somente a forma de uma prescrição, sem atentar para a finalidade ou finalidades reais às quais ela deve atingir.

O formalismo processual, conhecido em todas as épocas, teve mais ou menos importância segundo as várias fases históricas. É indubitável que atualmente tende a considerar mais a finalidade e o conteúdo dos atos que a exteriorização formal. Nesse sentido, defende Enrique Véscovi, ${ }^{317}$ ex-catedrático em direito processual da Universidade de Montevidéu, que não importa a infração formal se, mediante uma forma distinta, se chega igualmente ao objeto fim do ato, pois o ato deve realizar-se da maneira mais adequada para alcançar o seu objetivo ou por fixação judicial. As formas são estabelecidas pelo legislador, aquele que possui indiscutivelmente essa faculdade.

No Dicionário Aurélio da língua portuguesa, o vocábulo “forma” tem vários significados, e na concepção jurídica indica o “conjunto de solenidades que devem ser observadas para que a declaração da vontade de alguém tenha eficácia jurídica”. Formalismo significa "qualidade ou caráter de formal” e, noutro significado, "exigência de rigor exagerado no cumprimento de normas e/ou princípios”. 318

O ato processual é espécie de ato jurídico que necessariamente há de ter uma forma, pois a vontade somente interessa quando manifestada por sinais exteriores, visto que a vontade não exteriorizada não interessa ao Direito. Como requisito de validade do ato processual, as normas determinam com antecipação uma forma de comportamento. A conformidade do ato com as regras jurídicas preestabelecidas constitui a sua legalidade, ou

\footnotetext{
${ }^{315}$ HAAK, Susan. O crescimento do significado e os limites do formalismo: perspectivas pragmáticas na ciência e no direito. Tradução de Rachel Herdy. In: RODRIGUEZ, José Rodrigo (Org.). A justificação do formalismo jurídico. São Paulo: Saraiva, 2011. p. 132.

${ }^{316}$ ALEXANDER, Larry. Comigo é tudo ou nada, formalismo no direito e na moralidade. Tradução de Thalia Simões Cerqueira. In: RODRIGUEZ, José Rodrigo (Org.). A justificação do formalismo jurídico. São Paulo: Saraiva, 2011. p. 166.

${ }^{317}$ VÉSCOVI, Enrique. Teoría general del proceso. 2. ed. Santa Fe de Bogotá: Temis, 1999. p. 226.

${ }^{318}$ FERREIRA, Aurélio Buarque de Holanda. Dicionário Aurélio da língua portuguesa. 5. ed. Curitiba: Positivo, 2010. p. 969-970.
} 
seja, tais regras consistem em uma espécie de modelo do ato. ${ }^{319}$ Quando se pratica um ato contrário ao modelo preestabelecido, pratica-se um ato ilegal.

Nos dizeres de Roque Komatsu, “as formas processuais correspondem a uma necessidade de ordem, certeza e eficiência e a sua escrupulosa observância representa uma garantia de andamento regular e legal do processo e de respeito aos direitos das partes”. O legislador impõe exigências técnicas e regras legais, subordinando a eficácia e validade do ato processual à observância dos requisitos da forma.

No mundo social, o ato processual é um fato que se manifesta no lugar e no tempo, com determinados elementos e requisitos, ou seja, de um modo determinado, que é a forma, prevendo a Lei as consequências da inobservância dos limites formais do ato. ${ }^{320}$ Dessa maneira, quando o ato é praticado em desconformidade com as regras, sofre as punições previstas em normas sociais de boa conduta.

No campo jurídico, forma, no sentido estrito, é a maneira pela qual o ato processual se exterioriza e, no sentido amplo, abrange as condições de lugar e tempo em que se leva a efeito o ato processual. Se o ato é praticado em desconformidade com o estabelecido em normas legais, sofre as consequências já previstas no modelo jurídico.

Enrico Tullio Liebman ensina que as modalidades do meio de expressão verbal ou escrita da língua, do tempo e do lugar em que se leva o ato processual a efeito constituem a forma em sentido estrito. Ainda, as formas processuais correspondem a uma necessidade de ordem, certeza e eficiência, e a sua escrupulosa observância representa uma garantia de andamento regular e legal do processo e de respeito nos direitos das partes, e por essas razões o legislador alçou algumas exigências técnicas e regras legais e subordinou a eficácia e validade à observância dos requisitos da forma. Além disso, a Lei estabeleceu também que os atos processuais deverão conter determinadas indicações ou referências consideradas úteis e necessárias. Esses requisitos, que se referem à perfeição do conteúdo do ato, tornam-se requisitos da forma, em sentido amplo. ${ }^{321}$

Giuseppe Chiovenda adota classificação diferente, pois vincula as condições de lugar, tempo e meios de expressão à forma no sentido estrito. Considerando forma no sentido amplo, as atividades necessárias ao processo, na medida em que são coordenadas à

\footnotetext{
${ }^{319}$ KOMATSU, Roque. Da invalidade no processo civil. São Paulo: RT, 1991. p. 128-129.

${ }^{320}$ Idem, p. 129.

${ }^{321}$ LIEBMAN, 1985, p. 225. No mesmo sentido KOMATSU, 1991. p. 129-130.
} 
atuação de um direito substancial, apresentam caráter de forma com respeito à substância. $^{322}$

No entender de Carlos Alberto Álvaro de Oliveira, essas condições não são intrínsecas ao ato, são apenas circunstâncias que, em razão de delimitarem os poderes dos sujeitos processuais e organizarem o processo, integram o formalismo processual, mas não a forma em sentido estrito, e constituem as formalidades consideradas como ato, fato ou prazo previsto por uma norma geral, com a finalidade de condicionar tanto as funções de um órgão quanto a de um agente. ${ }^{323}$

Cândido Rangel Dinamarco, ao escrever sobre a instrumentalidade, afirma que o processo se rege por normas de direito, as quais determinam como o processo se realiza e como a jurisdição se exerce, o que reduz o comportamento de cada um dos sujeitos do processo. Portanto, evita a situação de extrema complexidade que poderia gerar incertezas e colocaria em perigo a própria integridade dos direitos e obrigações da ordem substancial e a fidelidade do processo aos seus objetivos. ${ }^{324}$

Assim, se o processo se desenvolvesse por atos aleatórios, ou seja, se os atos fossem praticados sem seguir uma determinada ordem, o litígio acabaria em uma disputa totalmente desordenada. Inexistiria qualquer garantia para as partes, bem como estas ficariam à mercê de arbitrariedades do órgão julgador.

No entanto, não se trata de apenas ordenar os atos, mas também de disciplinar o poder do juiz e, nessa esteira de raciocínio, a forma na qual os atos devem ser praticados atua como garantia da liberdade contra o arbítrio dos órgãos estatais que detêm o poder jurisdicional. ${ }^{325}$ Ao órgão julgador cabe aplicar o direito segundo a sua livre convicção, porém, mesmo não sendo escravo da norma, não poderá relegá-la.

As crises originadas no direito material encontram no processo o método estatal de solução. O legislador, ao regulamentar o processo, procura estabelecer os meios destinados

\footnotetext{
${ }^{322}$ CHIOVENDA, Giuseppe. Principii di diritto processuale civile. 4. ed. Napoli: Jovene, 1928. § 43, 1, p. 662-663.

${ }^{323}$ Nesse sentido, salienta o autor que "a realização do procedimento deixada ao simples querer do juiz, de acordo com as necessidades do caso concreto, acarretaria a possibilidade de desequilíbrio entre o poder judicial e o Direito das partes" (OLIVEIRA, Carlos Alberto Alvaro de. O formalismo no processo civil. Proposta de um formalismo-valorativo. 4. ed. São Paulo: Saraiva, 2010. p. 27).

${ }^{324}$ DINAMARCO, 2009b, p. 213.

${ }^{325}$ OLIVEIRA, Carlos Alberto Alvaro de, 2010. p. 29.
} 
a possibilitar que esse instrumento atinja o seu escopo, criando a técnica processual que deve ser concebida à luz dos princípios que regem o sistema jurídico. ${ }^{326}$

Pode-se concluir que a forma, tanto no seu sentido restrito quanto no seu sentido amplo, é necessária à instauração e desenvolvimento do processo, pois faz parte da instrumentalidade que propicia às partes uma visão do caminho a ser seguido para chegar ao escopo almejado, ou seja, à solução do conflito.

Enrico Tullio Liebman afirma que o formalismo é mais necessário ao processo do que outras atividades, porém é preciso evitar ao máximo que as formas sejam um embaraço e um obstáculo à plena consecução do escopo do processo. É essencial impedir que a cega observância à forma sufoque a substância do direito. Salienta o processualista italiano que, ao regular as formas, que em grande parte são o resultado de uma experiência tradicional que se acumula há séculos, o legislador deve preocupar-se em adaptá-las às necessidades e aos costumes do seu tempo, eliminando o excessivo e o inútil e, além disso, o intérprete deve lembrar-se de que elas são meios, e não fins. ${ }^{327}$

Nos Estados Unidos, Robert S. Summers afirma que os acadêmicos americanos e os operadores do direito condenam instintivamente tudo o que havia e há de errado com o direito e o raciocínio jurídico sob a denominação “formalista”, principalmente a formalidade excessiva. ${ }^{328}$

Para Carlos Alberto Álvaro de Oliveira, o formalismo, ou forma em sentido amplo, implica a totalidade formal do processo, compreendendo não só a forma, ou as formalidades, mas especialmente a delimitação dos poderes, deveres e faculdades dos sujeitos do processo, bem como a coordenação de sua atividade, ordenação do procedimento e organização do processo, visando atingir suas finalidades primordiais. Portanto, o formalismo delimita o começo e o fim do processo, circunscrevendo o material a ser formado, estabelecendo os limites de ação das partes para o desenvolvimento do processo. $^{329}$

Entendimento diverso tem Cândido Rangel Dinamarco, para quem a exigência das formas é um penhor da segurança destas, que se destina a dar efetividade aos poderes e

${ }^{326}$ BEDAQUE, José Roberto dos Santos. Efetividade e técnica processual. 3. ed. São Paulo: Malheiros, 2010. p. 73-74.

${ }^{327}$ LIEBMAN, 1985, p. 226.

${ }^{328}$ SUMMERS, Robert S. O caráter formal do direito. Tradução de Manoel Gustavo Neubarth Trindade. In: RODRIGUEZ, José Rodrigo (Org.). A justificação do formalismo jurídico. São Paulo: Saraiva, 2011. p. 239.

${ }^{329}$ OLIVEIRA, Carlos Alberto Alvaro de, 2010. p. 28. 
faculdades inerentes ao sistema processual, consubstanciado no devido processo legal: “o que se renega no direito formal é o formalismo, entendido como culto irracional da forma, como se fora esta o objetivo em si mesma”. 330

\subsection{Aspecto positivo do formalismo, técnicas processuais e efetividade do processo}

Para a aplicação do direito material, torna-se necessária a utilização do direito processual que estabelece uma série de normas e formas para a instauração do processo que objetiva a solução de um conflito. $\mathrm{O}$ acesso à justiça ocorre de maneira ordenada, por meio de petição inicial dirigida a um juiz que tenha competência para dirimir aquele tipo de demanda, de acordo com as normas de organização judiciária, seja na esfera municipal, estadual ou federal, bem como com base em normas relativas a cada localidade.

Após a propositura da ação, o processo seguirá de conformidade com o procedimento inerente a cada tipo de modelo descrito pelo legislador, em atendimento a princípios processuais e fundamentais, bem como a ritos formais previamente determinados pelo Código de Processo Civil, ou por leis extravagantes.

Os órgãos estatais não aplicam o direito às situações concretas aleatoriamente. $\mathrm{Na}$ realidade, a atividade processual também é regulada pelo ordenamento jurídico, por meio de formas que devem ser obedecidas por aqueles que nela intervêm. Somente os atos realizados segundo o modelo legal são considerados válidos e aptos a produzirem os efeitos desejados. O legislador estabelece sanções para os atos que não estão em conformidade com o padrão legal, variando de intensidade segundo o maior ou menor desvio do tipo legal. ${ }^{331}$

A técnica processual organiza e define limites no desenvolvimento dos processos judiciais, colocando termo a uma eventual desordem que poderia advir da liberdade da prática desordenada dos atos processuais.

Uma dose de formalismo é necessária ao escopo de assegurar a certeza dos atos e do procedimento e aos escopos de garantia das partes, para não pairar dúvida. No entanto,

\footnotetext{
${ }^{330}$ DINAMARCO, 2009, p. 40.

331 FERNANDES, Antonio Scarance; GOMES, Antonio Magalhães; GRINOVER, Ada Pellegrini. As nulidades no processo penal. São Paulo: RT, 1997. p. 17-18.
} 
sob numerosos aspectos, o formalismo excessivo provoca complicações desnecessárias e aumenta o risco de que o processo venha envolver-se em excesso de nulidades e vícios de forma, ${ }^{332}$ o que consequentemente prejudica as partes litigantes.

O aspecto positivo da instrumentalidade do processo é caracterizado pela preocupação em extrair do instrumento do processo o máximo proveito na obtenção dos resultados, mescla-se à problemática da efetividade do processo e conduz à assertiva de que o processo deve atingir todos os escopos institucionais, e ser apto a cumprir integralmente toda a sua função sociopolítico-jurídica. ${ }^{333}$

Segundo José Roberto dos Santos Bedaque, a técnica ou formalismo processual possui dois grandes objetivos: um seria garantir a segurança do instrumento, proporcionando igualdade de tratamento às partes do processo, possibilitando-lhes influir substancialmente no resultado; o outro seria assegurar que a tutela jurisdicional seja, dentro do possível, uma resposta idêntica à atuação espontânea da regra do direito material, seja sob o prisma da justiça da decisão, ou do ponto de vista da tempestividade. ${ }^{334}$

É imprescindível que a técnica processual seja considerada como um elemento capaz de propiciar às partes a segurança e a certeza na maneira como o processo será desenvolvido, o que jamais seria alcançado, caso estivesse diante de um procedimento livremente construído em cada hipótese concreta, sem um roteiro predeterminado.

Nessa mesma linha de raciocínio, Mauro Cappelletti e Garth Bryant, na célebre obra Acesso à justiça, afirmam que os juristas precisam reconhecer que as técnicas processuais servem a funções sociais, e que qualquer regulamentação processual tem um efeito importante sobre a forma como opera a lei substantiva. ${ }^{335}$ Se o processo é analisado como instrumento de pacificação social e é prolongado demasiadamente no tempo, a satisfação dos interesses das partes não é obtida por ele. ${ }^{336}$

Também nesse sentido, Cândido Rangel Dinamarco salienta que compete à técnica processual o equilíbrio de exigências conflitantes, tais como a de justiça e celeridade, ou de

\footnotetext{
${ }^{332}$ DENTI, et TARUFFO, 1986, p. 291.

333 DINAMARCO, 2009b, p. 377.

${ }^{334}$ BEDAQUE, 2010. p. 78-79.

335 CAPPELLETTI, Mauro; BRYANT, Garth. Acesso à justiça. Tradução de Allen Gracie Northfleet. Porto Alegre: Fabris, 2002. p. 12.

${ }^{336}$ Nesse sentido, Fernando da Fonseca Gajardoni: “Para que o processo cumpra com eficácia o fim social para que concebido, propiciando não só satisfação jurídica, mas também efetiva, é preciso que se desenvolva em um período razoável” (Princípio constitucional da tutela jurisdicional sem dilações indevidas e o julgamento antecipadíssimo da lide. Revista IOB de Direito Civil e Processual Civil, São Paulo, ano VII, n., p. 106, jan.-fev. 2007).
} 
celeridade e ponderação, mas o que se tem na realidade é a necessidade de dotar o processo de meios que o leve, o mais rápido possível, a proporcionar a pacificação social no caso concreto, sem prejuízo da qualidade da decisão. Isso constitui, por um lado, fidelidade ao direito material e de outro, penhor da justiça das decisões. ${ }^{337}$

A efetividade consiste na aptidão para desempenhar, do melhor modo possível, a função própria do processo, ou seja, para atingir da maneira mais perfeita o seu fim específico que é, no plano jurídico, a solução do litígio por meio de sentença de mérito. ${ }^{338}$

A efetividade da justiça civil significa sem dúvida, em primeiro lugar, celeridade do processo, mas não celeridade a qualquer custo, e, sim, somente com pleno respeito das exigências de defesa do autor e, mais ainda, ao que lhe for útil, uma vez que ele não escolheu o tempo de duração da sua causa em juízo. ${ }^{339}$

José Carlos Barbosa Moreira ensina que “efetividade consiste na aptidão para desempenhar, do melhor modo possível, a função própria do processo”, e salienta que o fim específico do processo de conhecimento, no plano jurídico, é a solução do litígio por meio da sentença de mérito a que tende toda atividade nele realizada. ${ }^{340}$

O escopo principal do processo, como meio de pacificação de conflitos, é a satisfação do interesse das partes. A instrumentalidade, a técnica processual e o formalismo, em sentido positivo, são os meios disponíveis para se alcançar o fim a que se destina o processo, ou seja, a obtenção de uma decisão justa, dentro de um tempo razoável.

O formalismo conforme acima exposto, em seu aspecto positivo, não poderá jamais ser visto com exagerada supervalorização da forma em detrimento do objetivo central do processo, que seria proporcionar às partes o devido acesso à justiça, ou seja, a busca do resultado do direito material almejado por aquele que procura o Judiciário com a finalidade de pôr fim a um litígio.

A técnica processual deve servir de veículo simples e racionalmente conduzido para a defesa dos direitos deduzidos em juízo, e não como armadilha pronta para eliminar esses direitos, ao primeiro sinal de descuido em sua representação, ou seja, o critério de distinção

\footnotetext{
${ }^{337}$ DINAMARCO, 2009b, p. 376.

${ }^{338}$ Nesse sentido, José Carlos Barbosa Moreira frisa que o adjetivo “jurídico” não tem apenas fins jurídicos, mas também fins sociais e políticos (A efetividade do processo de conhecimento. Revista de Processo, São Paulo, ano 19, n. 74, p. 128, 1994b).

${ }^{339}$ TARZIA, Giuseppe. Crisi e riforma del processo civile. Rivista di Diritto Processuale. Padova, anno XLVI, Seconda serie, n. 3, p. 639, 1991.

340 BARBOSA MOREIRA, 1994b, p. 128.
} 
entre o vencedor e o sucumbente em um processo não pode ser a maior habilidade no manejo das formas processuais, pois o destino de um processo deve ser selado nos ditames do direito material, e não no direito processual. ${ }^{341}$

\subsection{Aspecto negativo do formalismo}

A função do processo é de ser instrumento de solução das controvérsias, porém, muitas vezes, não cumpre essa função, pois, em razão do excesso de formalismo, desvia-se do seu objetivo, que é a solução do litígio levado ao Judiciário, para problemas relacionados com a técnica processual. Transformando-se em outra fonte de conflito, passando a ser o ponto principal do processo, ou seja, as questões processuais acabam recebendo mais atenção do que a disputa oriunda do direito material que originou o litígio.

Todo conflito tem como base fatos da vida real, de alguma forma baseados na infringência a algum modelo previsto no direito material. Para a solução desse conflito, os interessados se valem do direito processual que irá, mediante a técnica processual, proporcionar meios para a sua solução, por meio de uma decisão que findará a demanda.

No entanto, quando a técnica processual é aplicada em excesso e passa a ser o centro das atenções das partes e do órgão julgador, em detrimento do bem da vida que objetivou a propositura da demanda, ela deixa de cumprir o seu papel, como meio de pacificação do conflito e nega o valor do processo, sendo este o aspecto negativo da instrumentalidade.

Nesse sentido, Cândido Rangel Dinamarco expressa que a excessiva preocupação com os temas processuais constituiu condição favorável às posturas inadequadas relativas a instrumentalidade realçada e invocada como fator de contenção de exageros e distorções, favorecendo o formalismo no modo de empregar a técnica processual, menosprezando a advertência de que as formas são apenas os meios preordenados de alcançar os objetivos específicos em cada momento processual. Salienta que, além disso, gera a falsa impressão de que os sucessos processuais criam direito para as partes, em que as atenções se desviam da real situação de direito material existente entre elas, para o modo como se comportam processualmente. O Código de Processo Civil teria contribuído com essa tendência

${ }^{341}$ OLIVEIRA, Bruno Silveira de, 2008, p. 33-34. 
processualizante, se não fossem o correto posicionamento da doutrina e o trabalho sadio dos juízes a respeito, quando instituiu o efeito da revelia e o associou ao julgamento antecipado do mérito. Numa primeira análise dos dispositivos, tem-se a impressão de que houve uma exacerbação do valor da conduta das pessoas, como sujeitos do processo e do próprio valor do processo, perante o valor do direito material e os seus objetivos. O autor ainda critica a postura eminentemente técnica utilizada durante décadas, superada na fase autonomista da história do direito processual, que soube abrir o sistema aos influxos constitucionalistas e à teoria geral. Com isso, vieram as preocupações de ordem social somadas àquelas de caráter eminentemente político. ${ }^{342}$

O citado processualista ainda salienta que tudo isso constitui o lado negativo da instrumentalidade processual. O valor do processo e das formas de procedimentos legais, advindos de séculos de experiência, é imensurável, e não se pode desprezar tampouco se quer desprocessualizar a ordem jurídica, mas a desmistificação das regras, critérios, princípios e do próprio sistema torna-se necessária. A observância empírica da ordem processual e das formas do procedimento, com ênfase da cláusula due process of law, é reconhecidamente penhor de segurança para as partes. Sem transformar as regras formais do processo "num sistema orgânico de armadilhas ardilosamente preparadas pela parte mais astuciosa e estrategicamente dissimuladas no caminho do mais incauto”, sem renegar o seu valor, o que se deseja é a colocação do processo em seu devido lugar, de instrumento que não pretende ir além de suas funções. O melhor penhor da segurança dos litigantes é o processo bem estruturado na lei e conduzido por um juiz racional e cônscio dos objetivos preestabelecidos. ${ }^{343}$

José Roberto dos Santos Bedaque também subscreve o entendimento de que o processo não vem cumprindo a sua função. O órgão judiciário que se destina à solução das controvérsias tem sido muito mais fonte de conflitos que meio de pacificação entre eles, “as denominadas 'questões preliminares', de natureza exclusivamente processual, acabam se transformando no objeto principal do processo, ofuscando a matéria de mérito, que muitas vezes sequer chega a ser examinada”. Para o autor, esse fenômeno não é privilégio de nosso país, mesmo que o tempo necessário ao término do processo e entrega da tutela

\footnotetext{
${ }^{342}$ DINAMARCO, 2009b, p. 316.

${ }^{343}$ Ibidem, p. 317.
} 
jurisdicional estejam acima do que seria razoável, cujo excesso de formalismo contribui decisivamente. $^{344}$

Esse tipo de formalismo em nada contribui para que a demanda tenha um desfecho digno do litígio levado à apreciação do Judiciário, ou seja, o exagero na valorização das formalidades processuais gera a inacessibilidade da justiça. ${ }^{345}$

\subsubsection{Efetividade, tempo e duração do processo}

O processo como atividade dinâmica se desenrola em um espaço de tempo. Nesse espaço de tempo cumprem-se os diversos atos processuais que constituem todo o processo, desde o princípio até o fim. O problema do tempo processual é a duração do processo, posto que se considera como um valor essencial da justiça a limitação da duração, porque o conflito deve chegar ao fim com a maior brevidade possível, pois a demora muitas vezes se converte em injustiça. Por outro lado, a excessiva limitação do tempo processual e de seus atos pode chegar a lesionar o direito de defesa que constitui um direito fundamental e uma garantia constitucional. ${ }^{346}$

Em outras palavras, no desenvolvimento dos atos processuais, valores relacionados com a tutela jurisdicional, tais como segurança e efetividade, são colocados em confronto, na medida em que, em linha de princípio, de um lado, um tempo maior para a obtenção de um provimento judicial adequado propicia maior segurança, de outro, a obtenção de provimentos mais rápidos favorece a maior efetividade da tutela jurisdicional. ${ }^{347}$

A morosidade indevida de um processo favorece aquele que não tem razão, o qual busca postergar o cumprimento do que é devido em detrimento do detentor do direito em discussão.

A duração do processo assemelha-se à inflação que à primeira vista supõe-se que prejudique a todos. No entanto, não é verdade, pois a inflação favorece alguns. Da mesma

\footnotetext{
${ }^{344}$ BEDAQUE, 2010. p. 76.

${ }^{345}$ MILLER, 2010.

${ }^{346}$ VÉSCOVI, 1999. p. 247.

347 Nesse sentido, Ricardo de Barros Leonel pondera que, levando-se em consideração esses aspectos, “o processo acaba realmente figurando como um 'jogo', no qual são contrapostos valores que deverão ser cotejados em busca da solução apropriada” (Revisitando a teoria geral dos recursos: o efeito suspensivo. In: NERY JR., Nelson; WAMBIER, Teresa Arruda Alvim (Coord.). Aspectos polêmicos e atuais dos recursos cíveis e assuntos afins. São Paulo: RT, 2006. v. 9, p. 469).
} 
forma, a demora do processo não é vista com os mesmos olhos por todas as pessoas que dele participam, há casos em que uma das partes ou seu advogado, ou ambos, ficam felizes quando o processo se arrasta por algum tempo. ${ }^{348}$

Processo justo é aquele que tende a uma sentença justa, compreendida como a sentença de mérito, e, quanto ao seu escopo, a sentença que atua o direito substancial, a sentença que finaliza com a composição da lide. Trata-se, em consequência, de verificar, de um lado, se a sentença justa confere novo vigor às garantias já presentes no ordenamento; de outro, como tais garantias se coordenam com o princípio da razoável duração do processo. ${ }^{349}$

Vincenzo Vigoriti enfatiza que a duração do processo não deve existir em prejuízo do autor que tem razão; o processo deve dar, o quanto possível, tudo aquilo que o seu direito consiste. $^{350}$

Giovanni Verdi comenta que na inauguração do ano judiciário de 2010 o Presidente da Corte de Cassação italiana, na qualidade de porta-voz de alguns empresários, declarou que a demora dos processos leva os investidores do país à preocupação com as lesões de direitos que uma justiça muito lenta provoca a quem pede justiça, de modo que há uma preocupação econômica pela incidência negativa que uma justiça tardia teria sobre o sistema produtivo italiano. O autor diz que na sua experiência de advogado, diante de controvérsias entre cidadãos, considera que quando estão em conflito dois operadores econômicos, há sempre um que quer lucrar com os tempos processuais longos e que, frequentemente, quem hoje espera por uma justiça tardia amanhã estará pronto a mudá-la em sua vantagem, em situação inversa. ${ }^{351}$

José Rogério Cruz e Tucci ensina que a eficácia da decisão será proporcionalmente mais fraca e ilusória, quanto mais distante da ocasião tecnicamente propícia for proferida a sentença, pois um julgamento tardio perde seu sentido reparador, quanto mais postergado for o momento do reconhecimento judicial dos direitos e transcorrido o tempo razoável

\footnotetext{
${ }^{348}$ BARBOSA MOREIRA, José Carlos. Notas sobre alguns fatores extrajurídicos no julgamento colegiado. Revista de Processo. São Paulo, ano 19, n. 75, p. 130, 1994d.

${ }^{349}$ POLI, Roberto. Giusto processo e oggetto del giudizio di appello. Rivista di Diritto Processualle, Milano, v. 65 (II Serie), p. 51-52, 2010.

${ }^{350}$ VIGORITI, Vincenzo. Costo e durata del processo civile: spunti per uma riflessione. Rivista di Diritto Civile. Padova, anno XXXII, n. 3, p. 319, 1986. Idem. Notas sobre o custo e a duração do processo civil na Italia. Revista de Processo, São Paulo, ano 11, n. 43, p. 143, jul.-set. 1986.

${ }^{351}$ VERDI, Giovanni. Il processo sotto l'incubo della ragionevole durata. Rivista di Diritto Processuale. Padova, anno LXVI, Seconda serie, n. 3, p. 508, 2011.
} 
para a solução do litígio, pois "qualquer solução será, de modo inexorável, injusta, por maior que seja o mérito científico do conteúdo da decisão”. 352

Geoffrey C. Hazard Jr., professor da Universidade de Yale, USA, afirma que em um sistema ordinário as causas simples estão sujeitas a longos e imprevisíveis atrasos, e o fluxo, pelo menos em termos americanos, chega o ponto de imobilidade. A própria condição de imobilidade sujeita uma simples causa a longos e imprevisíveis atrasos. Conclui que o resultado é a injustiça, pois a verdade é "justiça retardada é justiça negada”. 353

Federico Carpi, ao tratar do acesso à Corte di Cazzazione Italiana e Corti Supreme dei Paesi Europei, discorre que não é errado observar que em todos os modelos encontrados, com particularidades próprias, o pêndulo oscila entre estes dois extremos, e, de tempo em tempo, nos países singulares e nas diversas épocas históricas investe-se a fundo numa ou noutra finalidade, não somente a segunda das escolhas abstratas das normas, mas das consequências concretas da estrutura organizacional, da atitude cultural dos juízes e dos advogados, das regras pelo acesso ao Judiciário. ${ }^{354}$

Na Itália, no ato de inauguração do ano judiciário de 2006, referindo-se ao ano de 2005, o Primeiro Presidente da Suprema Corte di Cassazione lamentava a paralisia da justiça civil, recordando que o tempo médio para a obtenção da conclusão de um processo civil é cerca de 12 anos (do momento da primeira audiência do juízo de primeiro grau, à decisão da cassação) e tal situação continua, visto que, ao inaugurar o ano judiciário de 2008, também lamentou, sobretudo quanto ao tribunal de apelação, onde a estagnação do processo segue o seu tempo máximo. ${ }^{355}$

Na França, os jurisdicionados enfrentam a demora com a instrução processual, adiamentos incompreensíveis e deliberações intermináveis, erros de procedimentos e indiferença dos magistrados. A Corte Europeia de Haia censura frequentemente a França por desrespeitar o art. 6. ${ }^{\circ}$ da Convenção dos Direitos Humanos, que determina: “toda

\footnotetext{
${ }^{352}$ CRUZ E TUCCI, José Rogério. Garantia do processo sem dilações indevidas. Garantias constitucionais do processo civil. ------ (Coord.) São Paulo: R. dos Tribunais. 1999. p. 236; Idem. Tempo e processo. São Paulo: RT, 1997. p. 65. No mesmo sentido: GAJARDONI, 2007, p. 107.

${ }^{353}$ HAZARD JR., Geoffrey C. Costo e durata del processo in Italia e in U.S.A. Rivista di Diritto Civile. Padova, anno XXXII, n. 3, p. 271-272, 1986.

${ }^{354}$ CARPI, Federico. L'accesso alla Corte di Cassazione italiana e alle Corti Supreme dei Paesi Europei. Revista de Processo. São Paulo, ano 37, v. 204, p. 198, fev. 2012.

${ }^{355}$ SANDULLI, Piero. Il diritto alla tutela giurisdizionale alla luce della dichiarazione universale del diritto dell'uomo del 10 dicembre 1948. Rivista Diritto Processuale. Milano, anno LXIV, Seconda Serie, n. 2, p. 389-390, 2009.
} 
pessoa tem direito de ter sua causa ouvida publicamente e com equidade, dentro de um prazo razoável”. 356

O Presidente da United States Court of International Trade, Edward D. Re, informa que o enorme aumento de controvérsias colocou à prova a capacidade do sistema judiciário americano na administração da justiça, e exemplifica que no ano de 1982 o número de ações civis propostas foi elevado a record. Nesse ano, pela primeira vez, as práticas judiciárias superaram 200.000 unidades, o que representa um aumento de 14,2\% em um ano. Em 1983, o número foi elevado para 230.000, com 17,8\% de aumento em relação ao ano precedente. Salienta que o Presidente da Corte Suprema, Warren Burger, solicitou ajuda para a resolução dos problemas em razão da crescente e complexa sobrecarga de trabalho. O aumento de ações na Suprema Corte é indicativo da situação de todos os outros tribunais em cada nível e ameaça forçar o sistema judiciário até o ponto de ruptura. ${ }^{357}$

Oscar Chase informa que, em 1988, o então Chief Justice Warren, ao discursar na sede da American Bar Association, afirmou que “intermináveis e injustificadas delongas em nossas cortes comprometem atualmente a base jurídica dos direitos de milhares de americanos corroendo, de maneira imperceptível, os alicerces constitucionais do governo dos Estados Unidos”. 358

O que se denota é que a demora na tramitação dos processos é fator preocupante não somente no Brasil, mas em vários países, e um julgamento tardio não demonstra justiça, pois, quanto maior o tempo transcorrido para a solução da controvérsia levada a juízo, menor será o seu sentido reparador.

No entanto, a maior rapidez no trâmite processual que se traduz em maior efetividade do processo não poderá colocar em risco a segurança processual, o que se conclui que se deve buscar um equilíbrio entre efetividade e segurança da tutela jurisdicional.

\subsection{A instrumentalidade das formas e 0 acesso à justiça}

\footnotetext{
${ }^{356}$ CRUZ E TUCCI, José Rogério. Tempo e processo. São Paulo: RT, 1997. p. 91.

${ }^{357}$ RE, Edward D. Sovraccarico, lentezza e costi del processo in U.S.A. Rivista di Diritto Processuale. Padova, anno XXXII, n. 3, p. 311-312, 1986.

${ }^{358}$ CHASE, Oscar G. Civil litigation delay in Italy and the United States. The American Journal of Comparative Law, v. 36, n. 1, p. 42, Winter 1988.
} 
Como já mencionado, o sistema judiciário brasileiro, assim como o de outros países, enfrenta grandes problemas relacionados com a excessiva demora na tramitação de processos, dentre os quais se tem: a) a deficiência estrutural do Poder Judiciário; b) a produção desenfreada de normas legais pelos legisladores, sempre prontos a atender aos interesses, não necessariamente legítimos, dos detentores ocasionais do Poder; e c) o aumento excessivo do número de demandas decorrentes da adoção, paradoxal, de técnicas destinadas a facilitar o acesso à Justiça àqueles que necessitam da tutela jurisdicional. ${ }^{359}$

Para Luigi Paolo Comoglio, o acesso à justiça significa (e não poderia deixar de significar) que qualquer indivíduo tem a incondicionada e efetiva liberdade de acessar a órgãos judiciais, a fim de demandar a tutela adequada e efetiva dos direitos e dos interesses substanciais sociais invocados. ${ }^{360}$

O nosso sistema constitucional contempla várias medidas destinadas a facilitar 0 acesso à justiça, como a assistência judiciária gratuita (CF, art. 5. ${ }^{\circ}$, LXXIV), juizados especiais (CF, artigos 24, I. e 98, I; Lei n. ${ }^{0}$ 9.099/1995), ampliação da legitimidade do Ministério Público (CF, art. 129), e todas essas medidas visam tornar mais acessível a tutela jurisdicional. Objetivando abrandar os efeitos danosos dessa anomalia, o legislador processual vem adotando várias formas de tutelas de urgência, por natureza, provisórias, destinadas simplesmente a assegurar a efetividade da providência final. As medidas de urgência, sejam conservativas ou antecipatórias, visam afastar o risco do dano decorrente da morosidade do processo, visto não ter a finalidade de solucionar definitivamente as crises do direito material. ${ }^{361}$

Consequentemente, a abundância de requerimentos de tutelas emergenciais gera decisões interlocutórias que são recorríveis por meio do recurso de agravo. As exigências de celeridade na solução de controvérsias, ainda que provisórias, levaram o legislador a

\footnotetext{
${ }^{359}$ BEDAQUE, 2010. p. 46-47.

360 Tradução livre, no original: “L’accesso alla giustizia significa (e non potrebbe significare) per qualsiasi individuo la incondizionata ed effettiva libertà di adire gli organi giurisdizionali, al fine di domandare (ed, a processo concluso, eventualmente ottenere) la tutela adeguata ed effettiva dei diritti o degli interessi sostanziali fatti valere” (COMOGLIO, 2005. p. 277).

${ }^{361}$ BEDAQUE, 2010. p. 47. Salienta o autor que "a tendência é admitir modalidade de tutela sumária, com aptidão para transformar-se em definitiva, embora sem adquirir imutabilidade. Trata-se de técnica processual caracterizada pela transferência dos males causados pela demora do processo àquele que aparentemente não tem razão. Teria ele o ônus de provocar a atividade jurisdicional para tentar desconstituir a eficácia da tutela de urgência. A adoção desse mecanismo acaba conferindo à tutela antecipada natureza de providência final, passível de imunização pela coisa julgada. O mecanismo não difere muito do julgamento antecipado, se verificada a revelia (CPC, art. 330, II). Aqui também a sentença é precedida de cognição não exauriente, pois fundada somente na versão apresentada pelo autor, e a decisão tem aptidão para tornar-se imutável”.
} 
autorizar, sob cognição superficial, a concessão liminar de providências cautelares e de antecipações de efeitos da provável sentença procedente. ${ }^{362}$

Noutras palavras, as tutelas de urgência, conservativas ou antecipatórias, são proferidas mediante decisões interlocutórias que quase sempre levam a parte sucumbente ao inconformismo demonstrado pela interposição de recurso de agravo.

De forma clara e sucinta, esclarece José Roberto dos Santos Bedaque: “o direito processual deve ser estudado pelo prisma da instrumentalidade substancial, ou seja, todos os seus institutos fundamentais constituem meios para tornar efetiva a tutela jurisdicional. Este é o resultado que se busca com o processo”. Salienta que o exagero de formalismo pode anular uma série de atividades desenvolvidas pelos sujeitos do processo, com vista à tutela. $^{363}$

Alerta, ainda, o processualista que em toda situação na qual o ato processual atingir o seu escopo, mesmo que praticado em desconformidade com o modelo legal, o ato deverá ser preservado e não deve ser decretada a sua nulidade, uma vez que o princípio da legalidade das formas e a necessidade de observância das regras do procedimento são garantias do resultado do processo, e não do atendimento à forma. ${ }^{364}$ Se, à luz do princípio da instrumentalidade das formas e da economia processual, for possível ignorar a falha processual, o mérito deverá ser julgado. ${ }^{365}$

Na mesma esteira de raciocínio, Cândido Rangel Dinamarco aduz que a regra da instrumentalidade das formas é de grande importância, uma vez que foi concebida para conduzir à interpretação de que nada há a anular quando determinado ato processual alcançou o seu objetivo, não ocorrendo prejuízo a qualquer dos litigantes ou ao correto exercício de jurisdição. Esse repúdio ao formalismo é realizado segundo os objetivos a atingir, mediante a flexibilização das formas e interpretação racional das normas que as exigem. $^{366}$

Se a nulidade do ato não acarretar nenhum defeito, e o escopo a que o ato se destina for alcançado, o ato deverá ser mantido.

\footnotetext{
362 CARNEIRO, 2005, p. 14.

363 BEDAQUE, José Roberto dos Santos. Direito e processo. 6. ed. São Paulo: Malheiros, 2011. p. 132-133.

${ }^{364}$ Isso, na opinião de Bedaque, aplica-se a qualquer tipo de nulidade, mesmo às absolutas (Ibidem, p. 133).

${ }^{365}$ Idem, p. 133; Idem. Nulidades processuais e apelação. Revista de Direitos e Garantias Fundamentais. Vitória, n. 1, p. 228-229, 2006b.

366 Salienta o autor que: “As exigências formais estão na lei para assegurar a produção de determinados resultados, como meios preordenados a fins: o que substancialmente importa é o resultado obtido e não tanto a regularidade no emprego dos meios” (DINAMARCO, 2009a, v. I, p. 41).
} 
Não existe razão para decretar a nulidade, se a sentença de mérito puder ser proferida em favor daquele a quem o reconhecimento da nulidade iria favorecer (art. 249, § 2. ${ }^{\circ}$, CPC). Verifica-se a aplicação do princípio da instrumentalidade das formas, projetado para o plano substancial. Os eventuais vícios do procedimento tornam-se irrelevantes, se a tutela jurisdicional for atingida sem ofensa ao devido processo legal e sem prejuízo aos princípios maiores do direito processual. ${ }^{367}$ Dessa forma, se o ato processual atingiu a sua finalidade, sem ofensa ao princípio do devido processo legal, mesmo existindo vícios, estes deverão ser relevados.

Observa-se nas reformas ocorridas no Código de Processo Civil, nos últimos 20 anos, a tendência em simplificar procedimentos, em dar maior flexibilidade à atuação dos juízes na solução dos conflitos, conferindo-lhes mais poderes em detrimento da segurança jurídica. ${ }^{368}$ Há mais de cinquenta anos já demonstrava Eduardo J. Couture essa mesma tendência no Judiciário uruguaio. ${ }^{369}$

No Brasil, paulatinamente, para combater a demora processual, o legislador foi privilegiando a instituição de mecanismos aceleratórios do processo, que acabam por distanciar a parte da pretensão da tutela jurisdicional. ${ }^{370}$

A reforma do Judiciário visa simplificar procedimentos objetivando a otimização processual para entregar às partes a tão almejada solução do conflito que objetivou o acesso à justiça.

\subsection{O equilíbrio entre o formalismo e o acesso à justiça}

Compete à técnica processual o equilíbrio de exigências conflitantes, ou seja, a coordenação de diversos escopos do processo. O escopo social magno do processo é sua chegada, o mais rapidamente possível, à promoção da pacificação social no caso concreto, sem prejuízo da qualidade da decisão. A boa qualidade da decisão, de um lado, abrange o

\footnotetext{
${ }^{367}$ BEDAQUE, 2011. p. 134.

${ }^{368}$ LUCON, Paulo Henrique dos Santos. O novo regime do agravo (Lei n. 11.185/2005). Revista do Advogado. São Paulo, ano XXVI, n. 85, p. 167, maio 2006.

${ }^{369}$ COUTURE, 1958. p. 349. "La tendencia de nuestro tiempo es la de aumentar los poderes del juez, y diminuir el número de recursos: es el triunfo de una justicia pronta y firme sobre la necesidad de una justicia buena pero lenta."

${ }^{370}$ TEDESCO, Paulo Camargo. O agravo na Lei 11.187/2005 e o princípio da oralidade. In: NERY JR., Nelson; ALVIM WAMBIER, Teresa Arruda (Coord.). Aspectos polêmicos e atuais dos recursos cíveis e assuntos afins. São Paulo: RT, 2006. v. 9, p. 419.
} 
escopo jurídico que se traduz na fidelidade ao direito material e, de outro, ao penhor da justiça das decisões. Toda gama de princípios e garantias constitucionais do processo, em especial o due process of law, se volta à efetiva fidelidade aos desígnios do direito material. $^{371}$

A nossa Constituição Federal de 1988, no inciso LXXVIII e parágrafos do artigo 5. ${ }^{\text {, }}$ assegura a todos, no âmbito judicial e administrativo, a razoável duração do processo e os meios que garantam a celeridade de sua tramitação.

A Convenção Europeia para Proteção de Direitos Humanos e Liberdades Fundamentais reconhece explicitamente, no artigo 6. ${ }^{\circ}$, “qualquer pessoa tem direito a que a sua causa seja examinada equitativa e publicamente, num prazo razoável por um tribunal independente e imparcial”.

É necessário remover as barreiras que obstruem o caminho da efetividade da justiça, entre elas o tempo excessivamente longo de atividade jurisdicional, como fator primário de proliferação de denegação substancial da justiça. ${ }^{372}$

A tutela jurisdicional precisa ser prestada num tempo razoável, ou seja, a obtenção de uma decisão legal do órgão jurisdicional competente deve ser prestada dentro de prazos legais preestabelecidos ou, não havendo previsão legal, que seja dentro de um prazo proporcional e adequado à complexidade do processo. ${ }^{373}$ No entanto, o excesso de formalismo, ou forma em sentido amplo, frequentemente acaba negando às partes a solução do conflito.

Muitas vezes, pode ocorrer de o formalismo excessivo, em vez de realizar o direito, aniquilar ou retardar, sem razoabilidade, a solução da lide. Nesse caso, o formalismo passa a ser o seu algoz, ou seja, em vez de colaborar para a realização do direito material, propiciando uma solução rápida e eficaz do processo, contribui com a sua extinção, sem julgamento de mérito, obstando que o processo atinja sua finalidade essencial. ${ }^{374}$

\footnotetext{
${ }^{371}$ DINAMARCO, 2009b, p. 376.

${ }^{372}$ COMOGLIO, 1998, p. 111.

373 ZANFERDINI, Flávia de Almeida Montingelli. Prazo razoável - direito à prestação jurisdicional sem dilações indevidas. Revista Síntese de Direito Civil e Processo Civil. Porto Alegre, ano IV, v. 22, p. 15, mar.-abr. 2003.

${ }^{374}$ Nesse sentido, Carlos Alberto Álvaro de Oliveira salienta que, "para afastar as consequências nefastas do formalismo excessivo, pernicioso ou negativo, mostra-se necessário que o jurista, o operador prático do direito, muna-se de ferramentas que impeça tal desvio de perspectiva" (O formalismo valorativo no confronto com o formalismo excessivo. Revista de Processo. São Paulo, p. 19, 2006).
} 
Em nosso sentir, o apego excessivo à forma engessa o direito. $\mathrm{O}$ formalismo que confronta com o bem jurídico que o legislador quis proteger se traduz na negação do direito e da ordem jurídica idealizada pelo legislador 


\section{A CRISE DOS TRIBUNAIS SUPERIORES}

A crise judiciária é mundial e a litigiosidade contagia vários países de Primeiro Mundo, tanto da Europa Continental, Inglaterra, quanto da América do Norte e Ásia.

José Carlos Barbosa Moreira salienta que há décadas participa de congressos internacionais sobre temas ligados ao processo, e em nenhum deixou de ouvir lamentações, vindas de todos os quadrantes do planeta, quanto à morosidade da Justiça. Ressalta que nos diferentes países são realizadas sucessivas reformas na legislação, mas todos evidenciam insatisfação generalizada com o desempenho da máquina judiciária, quanto ao respectivo ritmo. Exemplifica com o caso da Itália, país considerado de Primeiro Mundo, com posição de relevo no campo da ciência jurídica, principalmente a processual, onde a duração média de um processo, na primeira instância, é de 35 meses (quase três anos) e de 65 meses (cerca de cinco anos e meio) em grau de apelação. ${ }^{375}$

O citado processualista em conferência anterior ${ }^{376}$ aduz que no Japão, antes da entrada em vigor do novo código, em 1998, não era raro que um feito, após se arrastar alguns anos na primeira instância, levasse mais de um decênio até eventual decisão na Corte Suprema. A Inglaterra, país anglo-saxão, descontente com o ritmo dos pleitos, quebrando sua multissecular tradição, se dispôs a adotar um Código de Processo Civil, semelhante, em vários pontos, ao modelo continental europeu. ${ }^{377}$

Salienta ainda o ilustre jurista que na sociedade norte-americana, a qual vemos como ícone de eficiência, em muitos órgãos é necessária a espera de quatro ou cinco anos para se chegar ao julgamento. Adverte que as estatísticas referentes aos Estados Unidos devem ser recebidas com reservas, em razão de o panorama ser muito variado, em virtude da pluralidade de sistemas processuais: ao lado da Justiça Federal, cada Estado tem a sua, regida por leis próprias, e o movimento forense varia de um Estado para outro. ${ }^{378}$

\footnotetext{
375 BARBOSA MOREIRA, José Carlos. O problema da duração dos processos: premissas para uma discussão séria. Temas de direito processual. Nona série. São Paulo: Saraiva, 2007a, p. 370-371.

${ }^{376}$ Pronunciada em 05.04.2000, no Rio de Janeiro, no seminário O Direito no Século XXI - Novos Desafios, comemorativo do 20. ${ }^{\circ}$ aniversário do CEPAD (BARBOSA MOREIRA, José Carlos. O futuro da justiça: alguns mitos. Temas de direito processual. Oitava série. São Paulo: Saraiva. 2004a, p. 2-3).

${ }^{377}$ Ibidem, p. 2-3. No mesmo sentido: Fernando da Fonseca Gajardoni acrescenta que na Inglaterra os prazos foram bem fixados, mas descumpridos (2007, p. 105-106).

${ }^{378}$ BARBOSA MOREIRA, 2007a, p. 371.
} 
Na França, Roger Perrot discorre sobre o considerável aumento da litigiosidade, uma vez que as demandas apresentadas aos tribunais se multiplicam em proporções inquietantes. Aduz que numa sociedade que evolui rapidamente as leis se sucedem em ritmo acelerado e fatalmente geram um contencioso mais abundante, haja vista que os contemporâneos, mais bem informados de seus direitos que as gerações do passado, não hesitam em dirigir-se aos tribunais ante a menor dificuldade, e, se necessário, percorrendo todos os degraus da hierarquia judiciária, desde o juiz de primeiro grau até a Corte de Cassação. Salienta que há um fenômeno de massa no mundo judiciário que acarreta consequências temíveis, pois a Justiça é fator de paz social, e não lhe é possível desempenhar plenamente o seu papel sem que as decisões sejam proferidas dentro de prazos razoáveis e executadas com rapidez. ${ }^{379}$

A multiplicação de conflitos e novas formas de atuação política provenientes das crises de hegemonia, de legitimidade e da matriz organizacional do Estado, obrigou o Estado brasileiro a promover constantes ajustamentos no tocante à organização socioeconômica e político-administrativa do País, sem no entanto, conseguir superar as próprias contradições em que tal organização se assenta. Nesse processo de ajuste, o fosso cada vez mais profundo entre o sistema jurídico e os interesses conflitantes numa sociedade em transformação, exponenciado pelas dificuldades que o Judiciário enfrenta hodiernamente para se adaptar aos novos tempos, conduziu a uma progressiva desconfiança, tanto na objetividade das leis, como critério de justiça, quanto na sua efetividade, como instrumento de regulação e direção da vida socioeconômica, ${ }^{380}$ isso aliado ao fato de que a população é mais esclarecida que outrora, visto que busca fazer valer os seus direitos a qualquer custo e espera uma resposta efetiva do Judiciário para a solução de seus conflitos. Essa é a explicação do crescimento exponencial da crise do sistema judiciário brasileiro.

Rodolfo de Camargo Mancuso discorre que se desenvolveu a tendência de se repassar à Justiça estatal os históricos de danos temidos ou sofridos, "comportamento insuflado pela difundida (e equivocada) ideia de que por aí se está a exercer cidadania”,

\footnotetext{
${ }^{379}$ PERROT, Roger. O processo civil francês na véspera do século XXI. Tradução de José Carlos Barbosa Moreira. Revista de Processo. São Paulo, ano 23, n. 91, p. 204, 1998.

380 FARIA, José Eduardo. O Judiciário e o desenvolvimento socioeconômico. In: ------ (Org.). Direitos humanos, direitos sociais e justiça. São Paulo: Malheiros, 1994. p. 12.
} 
salientando que houve a formação de uma arraigada cultura demandista que desserve a verdadeira cidadania e fomenta a crise numérica dos processos judiciais. ${ }^{381}$

\subsection{Tribunais superiores - uma avalanche de processos e poucos ministros para julgar}

A origem do Supremo Tribunal Federal se deu com a Casa da Suplicação do Brasil que vigorou entre 1808 e 1829.

Com a chegada da Família Real portuguesa ao Brasil, estabeleceu-se o mero domínio ultramarino de Portugal, e, por Alvará Régio de 10 de maio de 1808, a Casa da Suplicação do Brasil, sediada no Rio de Janeiro, é investida da mesma competência atribuída à Casa da Suplicação de Lisboa. ${ }^{382}$

A Constituição Federal de 1824 estabeleceu em seu artigo $163^{383}$ a criação de um tribunal denominado Supremo Tribunal de Justiça, composto por dezessete juízes, que passou a suceder a Casa da Suplicação a partir de 1829. Esse tribunal subsistiu até fevereiro de 1891.

O Supremo Tribunal Federal foi criado no ano de 1890, por meio do Decreto n. ${ }^{\circ}$ 510 e era composto de quinze ministros, tendo o número de ministros sido reduzido para onze pelo Governo Provisório, após a Revolução de 1930, por meio do Decreto n. ${ }^{0}$ 19.656, de 1931.

A Constituição de 1934 mudou a denominação do órgão para "Corte Suprema” e manteve o número de onze ministros. A Constituição de 1937 restabeleceu o título de

\footnotetext{
${ }^{381}$ MANCUSO, Rodolfo de Camargo. Acesso à justiça. São Paulo. RT, 2011. p. 452. “[...] haveria, ao interno da coletividade brasileira, uma propensão a repassar às mãos do Estado a tarefa e a responsabilidade de dirimir os conflitos, fazendo com que o Judiciários opere como um receptáculo imediato (uma sorte de guichê universal de reclamações) recepcionando toda sorte de pretensões, resistências, insatisfações e intolerâncias, ainda que de pequena monta ou de parca senão nenhuma complexidade ou relevância” (p. 54).

${ }^{382}$ Esclarecem Luiz Carlos de Azevedo e José Rogério Cruz e Tucci que, excetuando-se o recurso de revista, das sentenças proferidas pela Casa da Suplicação do Brasil não cabia recurso algum (Lições de história do processo civil lusitano. São Paulo: RT; Coimbra: Coimbra Editora, 2009. p. 174-175).

${ }^{383}$ Previa o artigo 163 da Constituição Federal de 1824: "Na Capital do Império, além da Relação, que deve existir, assim como nas demais Províncias, haverá também um Tribunal com a denominação de Supremo Tribunal de Justiça, composto de Juízes letrados, tirados das Relações por suas antiguidades; e serão condecorados com o título do Conselho. Na primeira organização poderão ser empregados neste Tribunal os Ministros daqueles que se houverem de abolir”.
} 
“Supremo Tribunal Federal”, que em 21.04.1960 foi transferido para Brasília, depois de ter funcionado durante 69 anos na cidade do Rio de Janeiro.

No período do regime militar, entre o Ato Institucional n. 2 de 1965 e o Ato Institucional n. ${ }^{\circ} 6$ de 1969, o número de ministros foi elevado para dezesseis, quando voltou a ser reduzido para onze, sendo este número mantido até hoje. ${ }^{384}$

A Constituição Federal de 1988 realçou expressamente a competência precípua do Supremo Tribunal Federal com a guarda da Constituição e criou o Superior Tribunal de Justiça destinando-lhe a proteção à lei federal e a uniformização da jurisprudência.

A crise do Supremo Tribunal Federal se traduz em duas consequências. A primeira é o acúmulo de processos sem decisão, em razão do número de processos que chegam anualmente exceder o número de julgamentos. Isso ocorre não por desídia dos ministros, mas sim por absoluta impossibilidade de eles darem conta do volume desmedido de trabalho. A segunda consequência se traduz na perda de substância dos julgados da mais alta Corte de justiça do País. Eles, que deveriam nortear a atividade jurisdicional do País, acabam apresentando-se como frutos modestos, muitas vezes nada convincentes, em razão da pressão intolerável do volume de trabalho. ${ }^{385}$

Roberto de Camargo Mancuso discorre que, se levarmos em consideração as competências do Supremo Tribunal Federal, não será difícil constatar que o acúmulo de serviço judiciário não deriva das causas de que ele conhece originariamente conforme inciso I e alíneas do artigo 102 da Constituição Federal, pois muitas delas não são apresentadas amiúde; outras resolvem-se no juízo de delibação, ou seja, de revisão sob o aspecto formal; em outras, cuida-se de julgamento de altas autoridades, por crimes comuns ou de responsabilidade, ressaltando que remanesce como causa mais palpável o próprio recurso extraordinário, pelo notável volume de processo que por meio dele chegam ao Supremo Tribunal Federal. ${ }^{386}$

As estatísticas revelam que o crescimento do número de recursos distribuído nos tribunais superiores ao longo das últimas décadas é alarmante, o que se pode verificar no

\footnotetext{
${ }^{384}$ Dados históricos encontrados no site do Supremo Tribunal Federal, no campo denominado institucional, disponível em: <http://www.stf.jus.br/portal/cms/verTexto.asp?servico=sobreStfConhecaStfInstitucional>. Acesso em: 3 mar. 2014.

${ }^{385}$ CALMON DE PASSOS, J. J. O recurso extraordinário e a emenda n. 3 do Regimento Interno do Supremo Tribunal Federal. Revista de Processo. São Paulo, ano II, n. 5, p. 45, 1977.

${ }^{386}$ MANCUSO, Rodolfo de Camargo. Recurso extraordinário e recurso especial. São Paulo: RT, 2012. p. 93-93.
} 
quadro $^{387}$ a seguir, que demonstra a movimentação de processos somente do Supremo Tribunal Federal, englobando decisões monocráticas (despachos) e decisões colegiadas (acórdãos):

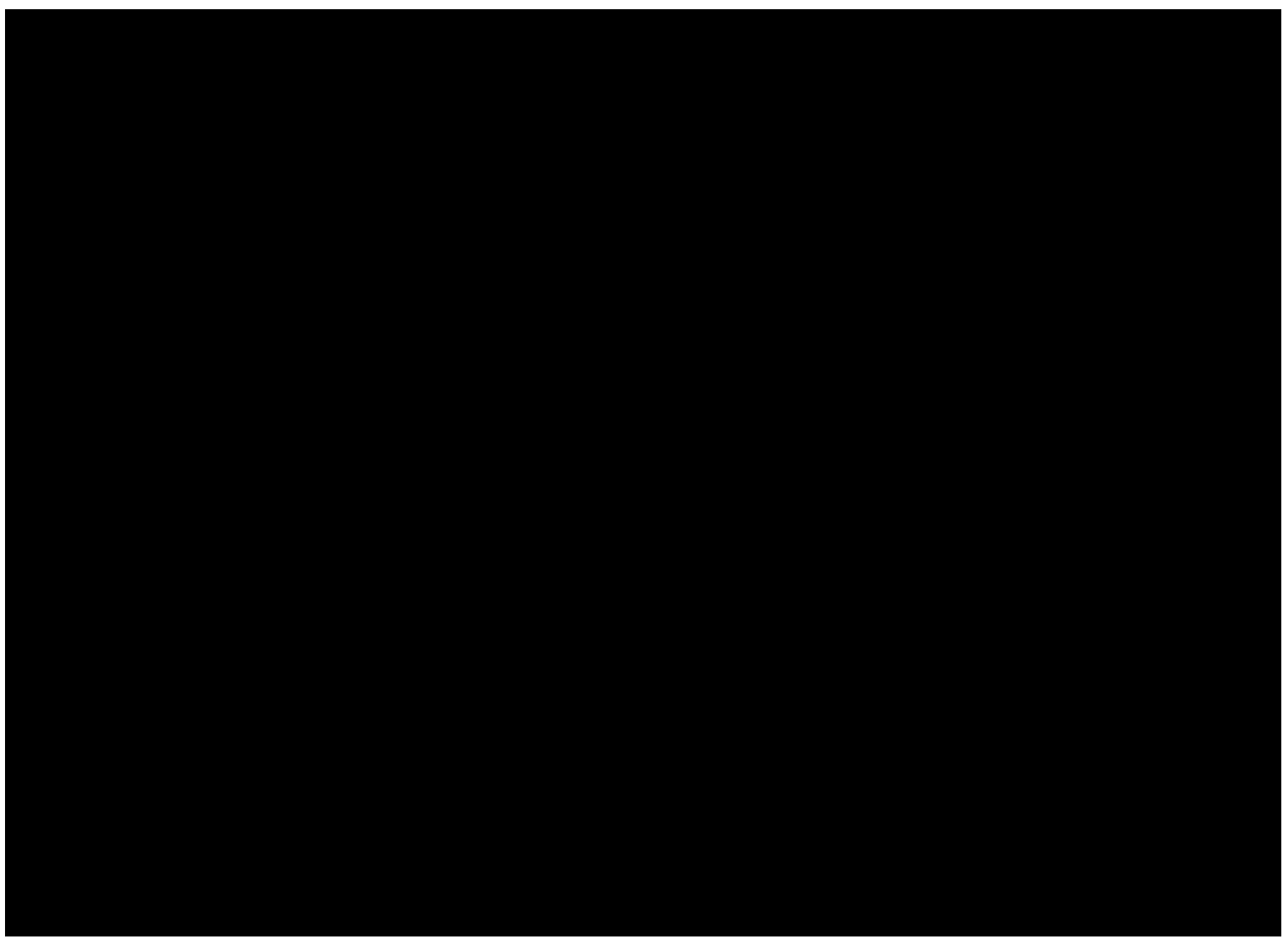

Verifica-se que houve um aumento exponencial do número de processos protocolados, distribuídos e julgados pelo Supremo Tribunal Federal.

Esses dados estatísticos mostram a desproporcionalidade existente entre o número de ministros e o número de processos. A título de exemplo, no ano de 1940, no Supremo Tribunal Federal foram julgados 1.807 processos, e, considerando-se que existiam 11 ministros, cada um julgou em média 164 recursos no período de um ano.

${ }^{387}$ Dados estatísticos encontrados no site do Supremo Tribunal Federal, no campo denominado institucional, disponível em: <http://www.stf.jus.br/portal/cms/verTexto.asp?servico=sobreStfConhecaStfInstitucional>. Acesso em: 3 mar. 2014. 
Em 2007, foi julgado o maior número de processos da história do Supremo Tribunal Federal: 159.522 processos, e coube a cada ministro, em média, 14.502 processos, no período de um ano.

Em período mais recente, ou seja, 2012, foram julgados 87.784 processos, ficando cada ministro com o julgamento, em média, de 7.980 processos, no período de um ano.

O Superior Tribunal de Justiça possui 33 ministros e a estatística demonstra que, apesar de ter somente 25 anos de idade, houve um crescimento exponencial no número de protocolos e distribuição de processos.

Em 1991 foram distribuídos 23.368 processos, incluídos recursos e ações de competência originária; em 1996, entraram 77.032 processos, dos quais 30.869 recursos especiais e 36.841 agravos; em 2001, 184.578 processos, dos quais 99.873 recursos especiais e 70.385 agravos; em 2003, 216.493 processos, dos quais 116.813 recursos especiais e 80.061 agravos. $^{388}$

Atualmente, os dados estatísticos do Superior Tribunal de Justiça são feitos pelo Conselho Nacional de Justiça, o qual demonstra que no ano de 2012 a movimentação processual desta Corte teve o seguinte resultado:

Estoque de processos: $\quad 316.317$

Casos novos: $\quad 261.382$

Casos julgados: $\quad 347.131$

Casos baixados: $\quad 280.104$

Saldo: $\quad 297.595$

O Conselho Nacional de Justiça ainda informa que a taxa de congestionamento de processos no Superior Tribunal de Justiça no ano de 2012 foi de 51,5\%, não sendo possível comparar com o ano anterior em razão de não ter sido informado o número de casos pendentes daquele ano. ${ }^{389}$

\footnotetext{
${ }^{388}$ Esses dados foram colhidos por Marcos André Franco Montoro no sítio do STJ (www.stj.gov.br), cujo site atualmente não mais disponibiliza dados estatísticos, que passaram a ser controlados pelo Conselho Nacional de Justiça. Os dados ora mencionados encontram-se: (2005, p. 104).

${ }^{389}$ Dados estatísticos fornecido pelo Relatório Justiça em Números 2013, do Conselho Nacional de Justiça, disponível em: <http://www.cnj.jus.br/images/pesquisas-judiciarias/Publicacoes/relatorio_jn2013.pdf > . Acesso em: 3 mar. 2014.
} 
Calmon de Passos, já em 1977, discorria que o Brasil se industrializou, seu comércio cresceu dezenas de vezes, as comunicações aproximaram os homens e multiplicaram suas relações, o Estado passou a intervir na ordem econômica e criou novas entidades que se situam na esfera administrativa indireta. O número de ministérios duplicou e as representações legislativas se fizeram numerosas, fatos esses que contribuíram para o congestionamento da Corte Maior. No entanto, essa Corte permaneceu imutável quanto ao número de ministros, desde 1931, ao passo que a sua competência se alargou gradualmente, no decorrer do tempo, especialmente como instância extraordinária, por meio de sucessivas ampliações de admissibilidade do apelo extremo, denominado recurso extraordinário. ${ }^{390}$

O Ministro Humberto Gomes de Barros em seu discurso de posse da presidência do Superior Tribunal de Justiça, em 07.04.2008, informava que aquela Corte transformou-se em terceira instância, recebendo indiscriminadamente apelos oriundos de 32 tribunais, espalhados em todo o Brasil, que os recursos especiais transformaram-se em ordinários e que no ano de 2007 cada magistrado apreciou, em média, 11.901 processos, e que a enormidade transparece ao se confrontar o artigo 106 da Lei Orgânica da Magistratura que fixa em 300 o limite de distribuição anual de processos por magistrado. ${ }^{391}$

Corroborando com essas assertivas, o quadro a seguir demonstra que o aumento demográfico populacional também cresceu de maneira exponencial, e ao mesmo tempo ocorreu a diminuição dos índices da taxa de analfabetismo no País:

(dados do IBGE)

\begin{tabular}{|r|r|r|}
\hline & \multicolumn{1}{|c|}{$\begin{array}{c}\text { População } \\
\text { Brasil }\end{array}$} & $\begin{array}{c}\text { Índice } \\
\text { Analfabetismo }\end{array}$ \\
\hline & & $56,2 \%$ \\
\hline $\mathbf{1 9 4 0}$ & 41.236 .315 & $50,5 \%$ \\
\hline $\mathbf{1 9 5 0}$ & 51.944 .397 & $39,6 \%$ \\
\hline $\mathbf{1 9 6 0}$ & 70.992 .343 & $33,6 \%$ \\
\hline $\mathbf{1 9 7 0}$ & 94.508 .583 & $25,5 \%$ \\
\hline $\mathbf{1 9 8 0}$ & 121.150 .573 & $20,1 \%$ \\
\hline $\mathbf{1 9 9 1}$ & 146.917 .459 & $13,6 \%$ \\
\hline $\mathbf{2 0 0 0}$ & 169.590 .693 & $9,6 \%$ \\
\hline $\mathbf{2 0 1 0}$ & 190.755 .799 & $9,6 \%$ \\
\hline $\mathbf{2 0 1 2}$ & 196.489 .677 & $9,6 \%$ \\
\hline $\mathbf{2 0 1 4}$ & 202.223 .555 & \\
\hline
\end{tabular}

${ }^{390}$ CALMON DE PASSOS, J. J. O recurso extraordinário e a emenda n. 3 do Regimento Interno do Supremo Tribunal Federal. Revista de Processo. São Paulo, ano II, n. 5, p. 44, 1977.

391 Disponível em: <http://ftp.stj.jus.br/portal_stj/publicacao/engine.wsp?tmp.area=551\&tmp.texto=87057>. Acesso em: 20 maio 2014. 
O que se verifica é que o aumento populacional também gera um número maior de processos que são anualmente protocolados nos tribunais superiores. O quadro a seguir demonstra aqueles do Supremo Tribunal Federal que mantêm o mesmo número de ministros, ou seja, onze.

\begin{tabular}{|r|r|r|}
\hline & \multicolumn{1}{|c|}{$\begin{array}{c}\text { População } \\
\text { Brasil }\end{array}$} & $\begin{array}{c}\text { Processos } \\
\text { Protocolados. } \\
\text { STF }\end{array}$ \\
\hline & & 2.419 \\
\hline $\mathbf{1 9 4 0}$ & 41.236 .315 & 3.091 \\
\hline $\mathbf{1 9 5 0}$ & 51.944 .397 & 6.504 \\
\hline $\mathbf{1 9 6 0}$ & 70.992 .343 & 6.367 \\
\hline $\mathbf{1 9 7 0}$ & 94.508 .583 & 9.555 \\
\hline $\mathbf{1 9 8 0}$ & 121.150 .573 & 18.564 \\
\hline $\mathbf{1 9 9 1}$ & 146.917 .459 & 105.307 \\
\hline $\mathbf{2 0 0 0}$ & 169.590 .693 & 71.670 \\
\hline $\mathbf{2 0 1 0}$ & 190.755 .799 & 72.148 \\
\hline $\mathbf{2 0 1 2}$ & 196.489 .677 & \\
\hline
\end{tabular}

Diante de uma população extremamente maior e mais esclarecida, haja vista a diminuição marcante do analfabetismo, além da maior facilidade de acesso à justiça, conclui-se que os cidadãos hoje procuram fazer valer os seus direitos, buscando o Poder Judiciário, bem como não temem em litigar em cada uma das instâncias que têm à disposição.

\subsection{Juízo de admissibilidade e técnica para restringir o número de processos nas instâncias superiores}

A crise que abrange o Supremo Tribunal Federal e o Superior Tribunal de Justiça se caracteriza pela desproporcionalidade, sempre crescente, entre a quantidade de processos que dão entrada diariamente no distribuidor e a capacidade de julgamento de ambos os tribunais dado ao número de julgadores.

Numa tentativa de dar uma solução ao problema do número astronômico de processos que abarrotam os tribunais superiores, foram feitas várias tentativas antes da promulgação da Constituição Federal de 1988, muitas das quais continuam sendo 
aplicadas. ${ }^{392}$ Foram criadas várias regras com a finalidade de desestimular, filtrar, restringir e até impedir que os recursos cheguem às Cortes Superiores.

A primeira tentativa de minorar a crise do Supremo Tribunal Federal foi em 1958 com a Lei n. ${ }^{\circ}$ 3.396, que permitia a triagem dos recursos extraordinários pelos tribunais locais. A competência para admissibilidade do recurso era do presidente dos Tribunais de Justiça dos Estados que efetuavam o exame do cabimento.

Em 1963, foram editadas as primeiras Súmulas de Jurisprudência Predominante, que passou a balizar, na instância inferior, a denegação do recurso e o seu não conhecimento no Supremo Tribunal Federal. Essa medida contribuiu, sem dúvida, para que muitos recursos extraordinários não fossem tentados ou se exaurissem na instância local. Nos dizeres de Calmon de Passos: a utilização das Súmulas de Jurisprudência Predominante encerra a desvantagem de pretender cristalizar entendimentos que são menos precários, sob a pressão do tempo, em relação àqueles contidos nas normas de caráter geral editadas pelo legislador. ${ }^{393}$

Em 1965, por meio de emenda regimental permitiu-se ao relator determinar a intimação das partes litigantes de recurso extraordinário que estivesse há dez anos ou mais no Tribunal e sem julgamento para que, em 90 dias, dissessem quanto ao seu interesse no andamento do feito, e o silêncio valia como perda do objeto do recurso.

Outra iniciativa foi a Emenda Constitucional n. ${ }^{\circ}$ 1, de 1969, que deferiu ao Supremo Tribunal Federal o poder de indicar em seu regimento interno as causas que, por sua natureza, espécie e valor, comportassem recurso, com apoio nas letras “a” e “d”, do inciso III do artigo 119 da antiga Constituição Federal, que correspondiam à maioria dos recursos extraordinários. Com isso, estabeleceu-se o incidente de relevância como meio de ensejar ao Supremo Tribunal Federal a oportunidade de escolher, entre os casos regimentalmente vetados, aqueles que mereciam o seu julgamento. ${ }^{394-395}$

\footnotetext{
392 FRANCO MONTORO, 2005, p. 105; PINTO, 1992. p. 38-50.

393 "Num setor como o Judiciário, onde as mudanças ocorrem a duras penas, criar instrumentos capazes de ainda mais dificultá-las é sempre agravar riscos de que temos sérias dúvidas representam o justo preço dos resultados obtidos em termos de simples aceleração dos julgamentos” (CALMON DE PASSOS, 1977, p. 46). ${ }^{394}$ GALVÃO, Ilmar Nascimento. O Poder Judiciário. O recurso especial no Superior Tribunal de Justiça. In: TEIXEIRA, Sálvio de Figueiredo. Recursos no Superior Tribunal de Justiça. São Paulo: Saraiva, 1991. p. 83-85.

${ }^{395}$ Michele Taruffo explica a diferenciação entre precedente e jurisprudência: “Quando se fala do precedente se faz normalmente referência a uma decisão relativa a um caso particular, enquanto quando se fala de jurisprudência se faz normalmente referência a uma pluralidade, frequentemente bastante ampla, de decisões relativas a vários e diversos casos concretos” (Precedente e jurisprudência. Revista de Processo. São Paulo, v. 199, p. 139, 2011).
} 
Tal medida acabou por engessar o sistema e os recursos que versavam sobre questões importantes, incluindo-se aqueles de eventual interesse do governo militar, que não podiam ser admitidos. Por essa razão, por meio da Emenda Constitucional n. ${ }^{0} 7$ de 1977, criou-se mecanismo da arguição de relevância, que permitia ao Supremo Tribunal Federal admitir recursos extraordinários relevantes. Esse mecanismo foi suprimido pela Constituição Federal de 1988, em razão das complexidades e obscuridades do procedimento da arguição de relevância. ${ }^{396}$

A promulgação da Constituição Federal de 1988 e a reforma do Poder Judiciário modificaram o panorama da cúpula do Judiciário brasileiro com a criação do Superior Tribunal de Justiça.

Ao Supremo Tribunal Federal foram conferidas atribuições jurídico-políticas de uma Corte Constitucional, limitado ao campo do recurso extraordinário e às causas decididas em única e última instância, quando a decisão recorrida: a) contrariar dispositivo da Constituição; b) declarar a inconstitucionalidade de tratado ou lei federal; e c) julgar válida lei ou ato de governo local contestado em face da Constituição, conforme previa originalmente o artigo 102, III, da Constituição Federal de 1988.

O Superior Tribunal de Justiça nasceu com a competência para julgar os recursos extraordinários que passaram a ser denominados de recurso especial, quando a decisão recorrida: a) contrariar tratado ou lei federal ou negar-lhes vigência; b) julgar válida lei ou ato de governo local contestado em face de lei federal; e c) der à lei federal interpretação divergente da que lhe haja atribuído outro tribunal, conforme previa originalmente o artigo 105, III, da Constituição Federal de 1988.

Os modelos de recurso extraordinário e recurso especial foram inspirados no direito norte-americano denominado writ of error, que era dirigido à Suprema Corte, possibilitando a revisão das decisões judiciais proferidas pelas Cortes locais relativas a questões de direito federal constitucional e infraconstitucional, além de proporcionar uma uniformização quanto a exegese do direito federal. ${ }^{397}$

\footnotetext{
${ }^{396}$ FREITAS JUNIOR, Horival Marques de. Repercussão geral das questões fundamentais. 2014. Dissertação (Mestrado) - São Paulo: USP, p. 22.

${ }^{397}$ FREIRE, Rodrigo da Cunha Lima. Prequestionamento implícito em recurso especial: posição divergente no STJ. In: NERY JR., Nelson; WAMBIER, Teresa Arruda Alvim (Coord.). Aspectos polêmicos e atuais dos recursos cíveis e de outras formas de impugnação às decisões judiciais. São Paulo: RT, 2001. v. 4, p. 958.
} 
A partir do desmembramento de competências do recurso extraordinário, boa parte da jurisprudência do Supremo Tribunal Federal, incluídas as suas súmulas sobre o recurso extraordinário, passou a ser aplicada pelo Superior Tribunal de Justiça, que a partir de seu nascedouro recebeu um acervo de processos exuberante. ${ }^{398}$ Como exemplo, a Súmula 283: "É inadmissível o recurso extraordinário, quando a decisão recorrida assenta em mais de um fundamento suficiente e o recurso não abrange todos eles"; Súmula 284: "É inadmissível o recurso extraordinário, quando a deficiência da sua fundamentação não permitir a exata compreensão da controvérsia”; Súmula 286: "Não se conhece do recurso extraordinário fundado em divergência jurisprudencial, quando a orientação do plenário do Supremo Tribunal Federal já se firmou no mesmo sentido da decisão recorrida”.

A Emenda Constitucional n. ${ }^{\circ} 45$ de 2004 e a Lei n. 11.417 de 2006 disciplinam a matéria relativa a súmulas vinculantes editadas pelo Supremo Tribunal Federal, como também preveem a possibilidade de revisão e de seu cancelamento.

A súmula vinculante tem por objetivo impor o entendimento estabelecido pelo Supremo Tribunal Federal, em plenário, pelo quorum de dois terços dos seus membros a todos os demais juízos e tribunais, bem como à Administração Pública, direta e indireta, conforme artigo 103-A, caput, da Constituição Federal e $\S 3 .^{\circ}$ do artigo $2 .^{\circ}$ da Lei n. ${ }^{\circ}$ 11.417 de 2006.

Ensina Arruda Alvim que a lei é, por excelência, a fonte de direito, e a súmula, em rigor, acaba por conter a interpretação de uma lei, cuja inteligência se torna obrigatória. Salienta o processualista que essa interpretação, oriunda do mais alto Tribunal de cúpula do País, objetiva apenas atribuir à lei interpretada o seu entendimento correto, de forma obrigatória. |Portanto, o mandamento é da lei e a interpretação obrigatória é da súmula. 399 Com isso, o entendimento da lei, obrigatoriamente, deverá ser aquele que contiver o enunciado da súmula vinculante.

Há outros óbices jurisprudenciais à admissibilidade dos recursos excepcionais, tais como: o prequestionamento, a interpretação razoável da lei, a impossibilidade de utilização de protocolo integrado, entre outros, muitos dos quais aplicados com um formalismo exagerado que será objeto de análise mais acurada nos capítulos seguintes deste estudo.

\footnotetext{
${ }^{398}$ FRANCO MONTORO, 2005, p. 105.

${ }^{399}$ ARRUDA ALVIM, José Manuel. Súmula e súmula vinculante. In: MEDINA et al. (Coord.). Os poderes do juiz e o controle das decisões judiciais. Estudos em homenagem à Professora Teresa Arruda Alvim Wambier. São Paulo: RT, 2008.
} 


\section{O EXCESSO DE FORMALISMO NO JUÍZO DE ADMISSIBILIDADE DOS RECURSOS NOS TRIBUNAIS SUPERIORES}

Como já vimos, os recursos se submetem a duas avaliações: uma concernente à impugnação, se puder ser apreciada em seu conteúdo, ou seja, se preencher os requisitos para a sua propositura, que é denominada "juízo de admissibilidade”; outra pela qual se examina o seu conteúdo, ou seja, se o recorrente tem ou não razão de impugnar a decisão recorrida, que se denomina "juízo de mérito".

A primeira avaliação, juízo de admissibilidade, é preliminar da segunda, juízo de mérito. Se faltar um requisito de admissibilidade, o recurso não passará para a segunda avaliação, ou seja, o mérito não será conhecido, não terá um julgamento.

Sempre que houver a ausência de qualquer requisito, será negado seguimento ao recurso. No entanto, não devem os tribunais exagerar, quando, por exemplo, se baseiam em circunstâncias que o texto não cogita, ou quando se apressam em negar seguimento ao recurso com base em dúvidas suscetíveis de suprimento.

Salienta José Carlos Barbosa Moreira que toda vez que, esteja clara a ausência de qualquer requisito de admissibilidade, a atitude correta é negar conhecimento ao recurso, porém não devem os tribunais exagerar na dose, por exemplo, arvorando em motivos de não conhecimento, circunstâncias não previstas no texto legal, nem mesmo implicitamente, agravando sem razão consistente exigências por ele feitas, ou apressando-se na interpretação desfavorável das razões do recorrente, as dúvidas que são suscetíveis de suprimento. ${ }^{400}$

Quando a decisão do juízo de admissibilidade se baseia em exageros pertinentes somente à forma, que são superáveis, ou seja, que são indevidos e ilegítimos, estará presente o formalismo, que deve ser repudiado.

Nesses casos, deve-se recorrer ao princípio da instrumentalidade das formas, o qual requer que estas não sejam excessivas para que não sufoquem os escopos jurídicos, sociais e políticos da jurisdição, assegurando as garantias das partes e a condução do processo ao

400 BARBOSA MOREIRA, 2007b, p. 270. 
seu destino final, que é a solução do conflito. É nesse sentido que Ada Pellegrini Grinover afirma que: "a técnica processual deve ser vista sempre a serviço dos escopos da jurisdição e ser flexibilizada de modo a servir à solução do litígio”. 401

Os tribunais superiores estão abarrotados de processos e por essa razão se cercam de entraves e exigências processuais alheias à própria lei, com o intuito precípuo de barrar o excesso de recursos, a fim de evitar a transformação das cortes de cúpula em mais uma instância recursal. Essa atitude não é bem vista pelos jurisdicionados e é combatida pela doutrina, visto que, de um lado, esses entraves eram justificados pela quantidade absurda de recursos, e, de outro, são medidas alheias ao regime democrático e empecilho ao amplo acesso à justiça. Convencionou-se nominar "jurisprudência defensiva” a prática da aplicação do descabido formalismo para impedir a continuidade da prestação jurisdicional, por parte do órgão judiciário. ${ }^{402}$ Essa jurisprudência afronta outros princípios que norteiam o sistema recursal como: princípio do devido processo legal, da celeridade processual e do acesso à justiça.

Na realidade, esses entendimentos são injustificáveis e devem ser rechaçados com todo o vigor, uma vez que ferem o princípio da instrumentalidade do processo e de instrumentalidade das formas, como também ofendem o princípio da inafastabilidade do controle jurisdicional. ${ }^{403}$

\subsection{A jurisprudência defensiva dos tribunais superiores}

Tanto o Supremo Tribunal Federal quanto o Superior Tribunal de Justiça praticam a denominada jurisprudência defensiva que consiste na criação de entraves e pretextos para impedir a chegada e o conhecimento dos recursos que lhe são dirigidos.

401 GRINOVER, Ada Pellegrini. Direito processual coletivo. In: LUCON, Paulo Henrique dos Santos (Coord.). Tutela coletiva. São Paulo: Atlas, 2006. p. 306.

${ }^{402}$ PEREIRA JUNIOR, José Aldizio. Em poucas palavras: dispositivos do Novo CPC contrários à jurisprudência defensiva. Conteúdo Jurídico. Brasília, 14 dez. 2013. Disponível em: <http://www.conteudojuridico.com.br/?artigos\&ver=2.46268>. Acesso em: 27 fev. 2014.

${ }^{403}$ Nesse sentido, Paulo Hoffman condena a prática: "impressiona que ainda haja tanto preconceito contra a 'repercussão geral', mas não se aceite passivamente que o recurso não seja conhecido - e, em tais casos, recursos que preenchem os pressupostos e mereceriam apreciação das altas corte - por não ter sido assinado ou por ter o carimbo do tribunal borrado ou, ainda, por falta de uma certidão que ateste que não há nos autos determinada peça (contrarrazões)" (Uniformização de jurisprudência (de $10^{\circ}$ grau). In: MEDINA et al. (Coord.). Os poderes do juiz e o controle das decisões judiciais. Estudos em homenagem à Professora Teresa Arruda Alvim Wambier. São Paulo: RT, 2008. p. 808). 
Outro artifício é a utilização da informática no exame e julgamento de processos repetitivos, que são agrupados conforme os temas e recebem decisão padronizada aplicada pelo computador e firmada por assinatura digital.

O Ministro Humberto Gomes de Barros, em seu discurso de posse na presidência do Superior Tribunal de Justiça, em 07.04.2008, salienta que em 1997 presidiu sessão em que foram julgados mais de 500 processos, os quais saíram dos tribunais locais e receberam do tribunal de cúpula decisão padronizada e retornaram à origem ou mergulharam em arquivo morto. O aproveitamento desses processos foi apenas de quem os manejou para retardar o cumprimento de suas obrigações, o que é lucrativo para o inadimplente, mas caríssimo para o litigante vitorioso e para todos os contribuintes. Informou que o custo do processamento da proliferação de processos no âmbito do STJ nos anos de 2007 e 2008 custou aos cofres públicos aproximadamente 140 milhões de reais. ${ }^{404}$

Discorre o Ministro que essa situação dolorosa agride a garantia constitucional da “razoável duração do processo” (art. 5. , LXXVIII, da Constituição Federal).

A jurisprudência defensiva se firma no juízo de admissibilidade em que os requisitos genéricos e específicos dos recursos são examinados com excessivo formalismo.

\subsection{Alguns casos de formalismo excessivo no juízo de admissibilidade}

São inúmeros os exemplos de formalismo excessivo no juízo de admissibilidade que restringe o conhecimento do mérito dos recursos, de modo que faremos referência a apenas alguns deles:

\subsubsection{Quanto ao requisito da tempestividade recursal}

Diz-se que um recurso é tempestivo quando sua interposição ocorre no prazo legal, e, como regra geral, a contagem do prazo é de que o termo inicial é o dia da intimação da decisão recorrível, quer se trate de sentença, decisão interlocutória ou acórdão.

${ }^{404}$ Disponível em: <http://ftp.stj.jus.br/portal_stj/publicacao/engine.wsp?tmp.area=551\&tmp.texto=87057>. Acesso em: 20 maio 2014. 
Há quatro interpretações quanto ao requisito da tempestividade recursal, que no nosso sentir são inaceitáveis.

\subsubsection{Intempestividade por prematuridade}

Diz respeito ao Supremo Tribunal Federal e ao Superior Tribunal de Justiça interpretarem como intempestivos por prematuridade quando o recurso extraordinário ou o recurso especial são opostos antes que as partes tenham sido intimadas do respectivo acórdão pela imprensa oficial, por entenderem que a decisão é inexistente antes de ocorrer a publicação.

Cândido Rangel Dinamarco ensina que a técnica dos julgamentos nos tribunais inclui várias providências tais como: 1) a discussão da causa entre os integrantes do colegiado; 2) a manifestação do voto de cada um e a proclamação do resultado; 3) a publicação desse resultado pela imprensa oficial; 4) os trabalhos de digitação, datilografia e impressão dos votos dos acórdãos; 5) assinatura do relator; 6) o registro do acórdão e por último a publicação das conclusões do acórdão, ou da parte dispositiva pela imprensa oficial. Salienta que essa interpretação dos tribunais tem considerado somente dois desses momentos, ou seja, o das publicações, não levando em consideração outros momentos mais importantes, por exemplo, a lavratura, assinatura, registro e juntada do acórdão aos autos. O processualista critica essa interpretação, visto que os próprios tribunais proclamam insistentemente que o prazo para interposição de recursos tem início em seguida a qualquer ato de ciência inequívoca, isto é, à prática de qualquer conduta mediante a qual a parte venha a tomar ciência da decisão recorrível. Salienta que a retirada dos autos do cartório ou secretaria do tribunal antes de feita a publicação pela imprensa é um desses atos, e que posterior publicação pela imprensa se torna indiferente, de modo que o prazo começa a fluir independentemente de quando for feita a publicação. ${ }^{405}$

\footnotetext{
${ }^{405}$ DINAMARCO, Cândido Rangel. Tempestividade dos recursos. Revista Dialética de Direito Processual, São Paulo, n. 16, p. 12, jul. 2004. No mesmo sentido, Flavio Cheim Jorge que aduz: "Se a ciência é o que marca o princípio do prazo recursal, este terá seu curso iniciado independentemente da forma ou do ato pelo qual a parte tome conhecimento e tenha acesso ao conteúdo da decisão - seja um daqueles previstos no art. 506 do CPC, ou outro qualquer” (Apontamentos sobre a tempestividade recursal: fluência inequívoca; recurso interposto antes da intimação; interrupção do prazo por força da interposição de embargos de declaração. Revista de Processo. São Paulo, ano 35, n. 181, p. 175, mar. 2010).
} 
José Roberto dos Santos Bedaque salienta que esse entendimento dos tribunais está equivocado e explica que, para sua melhor compreensão, basta lembrar que a categoria dos atos de comunicação processual a que pertencem a citação e a intimação, cuja finalidade, guardadas suas especificidades, é levar ao conhecimento das partes algum acontecimento verificado no processo, para que possam tomar as providências devidas para a defesa de seus respectivos interesses. Tomando-se por base esse entendimento, pode-se admitir a existência de um processo sem ato de comunicação processual, em que nenhuma irregularidade existiria se as partes, cientes da propositura da ação e de todos os atos subsequentes, interviessem de forma espontânea, participando ativamente para a formação do convencimento do julgador. Se o réu, por exemplo, apresentar defesa antes de ser citado, tanto melhor, pois se economizam tempo e despesas. ${ }^{406}$

Barbosa Moreira entende que se equipara à intimação, para efeito de fazer correr o prazo, qualquer ato que demonstre a inequívoca ciência da decisão, como a retirada dos autos de cartório pelo advogado. Salienta que a forma prescrita na lei deve ser observada, desde que não se tirem consequências drásticas da sua inobservância, quando desta se atingiu o fim do ato, sem prejuízo para qualquer das partes, afirma que aqui se encontra uma boa aplicação do princípio da instrumentalidade das formas. Esse raciocínio é válido para o caso de interposição do recurso anterior à intimação da decisão ou à prática de ato a ela equiparável. Os tribunais reiteradamente têm julgado intempestivos os recursos quando interpostos não somente além do prazo, mas também antes de o prazo começar a fluir, e justificam este último argumentando que a decisão recorrida ainda não existia juridicamente quando da interposição do recurso, o que induz à falta de objeto para a sua propositura. No entanto, a decisão existe desde que foi proferida. Se o recorrente foi capaz de impugná-la, é óbvio que conhece o seu teor e, consequentemente, foi alcançada a finalidade essencial do ato destinado a dar ciência do pronunciamento aos interessados. Neste caso, não houve prejuízo algum decorrente da interposição antecipada para qualquer das partes, o que torna ilegítima a restrição ao conhecimento do recurso. ${ }^{407}$

Humberto Theodoro Junior aduz que não é razoável a interpretação que conduz à intempestividade do recurso protocolado prematuramente e salienta que não se harmoniza com a moderna visão da instrumentalidade e economia processual que domina o processo civil, no campo de acesso à justiça. Recurso prematuro, de maneira alguma deve ser

\footnotetext{
${ }^{406}$ BEDAQUE, 2010. p. 159-160.

${ }^{407}$ BARBOSA MOREIRA, 2007b, p. 274-275.
} 
interpretado como recurso intempestivo, visto serem situações completamente heterogêneas, que não podem ser tratadas como iguais, sob pena de serem desprezadas a funcionalidade do processo e comprometerem a garantia fundamental do due process of law. ${ }^{408}$

\subsubsection{Necessidade de ratificação do recurso}

A segunda interpretação equivocada encontra-se na obrigação de o recorrente ratificar o recurso interposto após o julgamento dos embargos de declaração opostos pela parte contrária.

Salienta Araken de Assis que a tese do recurso ante tempus, que ocorre quando o recurso é proposto antes dos embargos de declaração e na fluência do seu respectivo prazo, é vista no Superior Tribunal de Justiça como recurso interposto intempestivamente, e há de ser reiterado em seus termos após a publicação do julgado integrativo, seguindo o litigante prudente essa linha de raciocínio, devendo a reiteração ocorrer no curso do prazo aberto com a intimação do julgamento dos embargos, sendo desnecessária a reprodução do recurso integralmente. ${ }^{409}$

A jurisprudência defensiva não tem base legal, ou decorre de interpretação errônea do texto da lei. Exemplo disso é a Súmula 418 do Superior Tribunal de Justiça, segundo a qual é "inadmissível o recurso especial interposto antes da publicação do acórdão dos embargos de declaração, sem posterior ratificação”.

Os julgados são implacáveis, considerando indispensável a ratificação do recurso interposto antes do julgamento dos embargos de declaração, qualquer que seja o resultado do julgamento desse recurso.

É certo que a decisão que julga os embargos de declaração, ainda que para rejeitálos, integra a decisão embargada. No entanto, a exigência de ratificação, se não houve

\footnotetext{
${ }^{408}$ THEODORO JÚNIOR, 2009, p. 568. Nesse sentido, Flavio Cheim Jorge salienta que: "não se coaduna com a interpretação do Código de Processo Civil e provoca consequências inconciliáveis no sistema recursal, que tem como premissa para a fluência do prazo recursal a ciência da parte, que não ocorre apenas quando a intimação se dá por um daqueles meios expressamente previstos” (2013. p. 193)

${ }^{409}$ ASSIS, 2008. p. 102.
} 
qualquer alteração na decisão embargada, é evidentemente injustificável, ${ }^{410}$ principalmente se não foi o recorrente quem opôs os embargos.

Esse aspecto foi destacado em voto do Ministro Cezar Peluso na Ação Rescisória n. ${ }^{\circ}$ 1.668, proferido em 14.10.2009, que tramitou no Supremo Tribunal Federal, o qual alerta para o equívoco, afirmando que não se deve exigir ratificação do recurso daquele que não interpôs embargos, após a rejeição dos embargos de declaração interpostos por outrem. Tal orientação veio a ser posteriormente reafirmada pela mesma Corte no julgamento do Agravo Regimental em Recurso Extraordinário n. ${ }^{\circ}$ 680.371, de 29.04.2013, Rel. Min. Dias Toffoli, e posteriormente no julgamento do Agravo Regimental em Recurso Extraordinário n. ${ }^{\circ}$ 740.688, de 03.09.2013, Rel. Min. Roberto Barroso.

A posição simplista que reputava intempestivos os recursos interpostos antes da publicação do acórdão recorrido foi igualmente repensada no ED no HC n. ${ }^{\circ}$ 101.132/MA, relatada pelo Ministro Luiz Fux em 24.04.2012, que argumentou: “a finalidade da publicação do acórdão é dar ciência à parte do teor da decisão, de modo que a interposição anterior do recurso denota que o referido propósito foi atingido por outros meios”. O Ministro concluiu que não faz sentido punir o recorrente diligente, que contribuiu com a celeridade processual. ${ }^{411}$

Em nosso sentir, a oposição do recurso especial ou extraordinário anteriormente à publicação do acórdão recorrido não prejudica o andamento do processo, nem qualquer uma das partes envolvidas. Além disso, se a finalidade da publicação do acórdão é dar ciência às partes do conteúdo decisivo, e se o interessado em recorrer tomou ciência da decisão por outros meios, a sua finalidade, ou seja, a ciência da decisão foi atingida, não sendo justa a inadmissibilidade do recurso que consubstancia punição da parte que agiu prontamente e com diligência em seu direito de recorrer.

Negar seguimento ao recurso por essa razão é negar acesso a um processo justo, é agir com formalismo exagerado, o que deve ser veemente combatido.

\footnotetext{
${ }^{410}$ MEDINA, José Miguel Garcia. Recursos “prematuros” e jurisprudência defensiva. Disponível em: <http://www.antonelliadv.com.br/DaVinci/site/antonelli/midia/140211123030arquivo_6.pdf > . Acesso em: 25 fev. 2014.

${ }^{411}$ ARRUDA ALVIM, José Manoel. STF rumo à flexibilização da jurisprudência defensiva. Disponível em: <http://www.oab.org.br/util/print/24648?print=Noticia>. Acesso em: 26 fev. 2014.
} 


\subsubsection{Comprovação da tempestividade em razão de causas locais}

A terceira interpretação relativa à tempestividade recursal se refere à necessidade de o recorrente comprovar, no ato da interposição dos recursos especial ou extraordinário, que o prazo recursal foi sobrestado ou prorrogado em decorrência de feriados ou recessos locais. Nesses casos é vedada ao recorrente a juntada da comprovação do evento que prorrogou o prazo de interposição do recurso posteriormente. ${ }^{412}$

O Supremo Tribunal Federal, no julgamento do AgReg no RE n. ${ }^{\circ}$ 626.358, em que foi relator o Ministro Cezar Peluso, modificou esse entendimento, aceitando a comprovação da tempestividade do recurso extraordinário, em razão de causa local. ${ }^{413}$

\subsubsection{Intempestividade quanto a data do protocolo do recurso}

No Judiciário de vários Estados foi implantado o protocolo integrado para a recepção de petições dirigidas a outros foros ou comarcas. Esse sistema facilita o trabalho do advogado no cumprimento dos prazos, haja vista que evita locomoções desnecessárias. $^{414}$

No entanto, o artigo 525 do Código de Processo Civil, com a redação dada pela Lei $n^{\circ}$ 9.139, de 30.11.1995, em seu $\S 2 .^{\circ}$ prescreve: "No prazo do recurso, a petição será protocolada no tribunal, ou postada no correio sob registro com aviso de recebimento, ou, ainda, interposta por outra forma prevista na lei local”. Essa redação muitas vezes gera no juízo de admissibilidade dos recursos um entendimento extremamente positivista e legalista quanto a expressão “lei local”, e o recurso de agravo deixa de ser conhecido, ou

\footnotetext{
412 CHEIM JORGE, 2013. p. 194.

${ }^{413}$ STF, Pleno, AgReg. 626.358, j. 22.03.2012.

${ }^{414}$ No Estado de São Paulo, o protocolo integrado dos foros estaduais foi implantado pelo Provimento 462/1985, do Conselho Superior da Magistratura. São Paulo: AASP Boletim 1997. Também na Justiça Federal de primeira instância da 3. ${ }^{a}$ Região, o protocolo integrado foi instituído pelo Provimento 148, de 02.06.1998, do Presidente do Conselho da Justiça Federal. São Paulo: AASP, 1998.
} 
seja, não ultrapassa o crivo do juízo de admissibilidade, em razão de ter sido interposto mediante o protocolo integrado. ${ }^{415}$

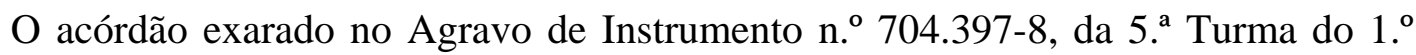
TACSP, menciona:

\begin{abstract}
Do r. pronunciamento agravado o recorrente tomou ciência expressa aos 16 de julho. Protocolou o recurso dentro do decêndio legal, mas na comarca de origem, aos 24 daquele mês, mediante o protocolo integrado, vindo, todavia, a petição a esta Corte somente no dia 31 de julho, além, portanto, do prazo da lei. Estabelece o art. 525, § 2. ${ }^{\circ}$, do CPC que a petição será protocolada no tribunal ou será postada no correio sob registro com aviso de recebimento, ou, ainda, interposta de outra forma prevista na lei local. Nenhuma das formas foi obviamente utilizada pelo agravante, que preferiu interpor o recurso mediante o protocolo unificado, que foi criado por provimento, distinto de lei. O entendimento aqui adotado vem sendo reiteradamente aplicado por esta eg. Câmara, máxime considerando-se a circunstância de que a nova redação dada ao procedimento do agravo de instrumento conferiu prazo em dobro para que o recorrente providenciasse o regular traslado e a protocolização do recurso. Posto isto, não conhecem do recurso do agravo. ${ }^{416}$
\end{abstract}

Salienta José Rogério Cruz e Tucci que o legislador, ao empregar a locução verbal “lei local”, refere-se a texto legal em sentido amplo, englobando até mesmo qualquer regulamento de organização judiciária, e que o Provimento n. ${ }^{\circ} 462$ do Conselho Superior da Magistratura, que instituiu o protocolo integrado no Judiciário paulista, dentre as exceções inseridas no seu artigo $1 .^{\circ}$, não faz qualquer restrição a que o recurso de agravo de instrumento seja remetido ao tribunal via protocolo integrado. ${ }^{417}$

O Superior Tribunal de Justiça chegou a emitir a Súmula 256 com o seguinte teor: “O sistema de 'protocolo integrado' não se aplica aos recursos dirigidos ao Superior Tribunal de Justiça”. Essa súmula vigorou de agosto de 2001 a maio de 2008, quando no julgamento do AgRg n. ${ }^{\circ}$ 792.846/SP a Corte Especial deliberou pelo seu cancelamento.

Vigora ainda no Superior Tribunal de Justiça a Súmula 216, cujo teor é: “A tempestividade de recurso interposto no Superior Tribunal de Justiça é aferida pelo registro no protocolo da Secretaria e não pela data de entrega na agência do correio”.

\footnotetext{
${ }^{415}$ Comentando esse tipo de situação, José Rogério Cruz e Tucci salienta que: "os cidadãos esperam destarte que o Judiciário, além de assegurar a plenitude de acesso à Justiça, faça incidir o ordenamento jurídico dentre de razoáveis premissas interpretativas". Tece uma crítica: "e tudo, sem que as partes ou seus patronos sejam sobressaltados por um fundamento inexplorado durante a tramitação do processo, ou mesmo por uma questão de natureza processual que extrapole as raias da lógica jurídica" (Lineamentos da nova reforma do CPC. 2. ed. São Paulo: Malheiros, 2002, p. 131-132).

${ }^{416}$ Ibidem, p. 132.

${ }^{417}$ Ibidem. p. 132.
} 
Jurisprudência recente demonstra que há inúmeros julgados que demonstram a aplicação da Súmula n. ${ }^{\circ}$ 216, considerando como intempestivos os recursos que não chegarem na secretaria do tribunal a quo no prazo recursal, mesmo que protocolados no protocolo integrado dos Estados. ${ }^{418}$

Em nosso sentir, se os recursos podem ser enviados ao tribunal via correio, seria muito mais produtivo considerar a tempestividade a partir da data de sua postagem na agência do correio, pois, se houve flexibilização por parte do tribunal na aceitação do envio do recurso pelo correio, torna-se sem sentido desconsiderar a data de sua postagem, mesmo porque o recorrente cumpriu o prazo, preparando as razões recursais a tempo e não pode ficar à mercê da eficiência do serviço postal para a aferição da tempestividade. Em épocas normais, as correspondências são entregues no máximo em 48 horas, mas em dezembro, por exemplo, por ocasião das festividades natalinas, as correspondências se multiplicam e uma correspondência normal pode demorar de 7 a 10 dias para ser entregue ao destinatário, e com isso, no caso do recurso, a tempestividade deixa de ser cumprida, trazendo prejuízo à parte recorrente.

A flexibilização que ora se propõe não é novidade para o Poder Judiciário, tendo-se em vista que atos processuais importantes como a citação são realizados a contento pelos Correios, visto que esse serviço é executado por particular, por meio de concessão governamental e perfeitamente aceita e prevista na lei processual.

Além das razões expostas, também se deve levar em conta a celeridade processual, pois a inadmissibilidade do recurso pela desconsideração da data da postagem do recurso gera a indignação do recorrente, o que o leva ao inconformismo e o impele à propositura de novos recursos, tais como os embargos de declaração, o agravo interno ou o agravo de instrumento, sendo que este último irá gerar novos autos processuais e mais acúmulo de processos a serem julgados pelos tribunais. Quando a simples aceitação da data do

\footnotetext{
${ }^{418}$ Conforme: STJ, 2. ${ }^{a}$ T., AgRg no AREsp 129839/RJ, j. 21.11.2013, DJ 29.1.2013, em que foi relatora a Ministra Eliana Calmon que deliberou: 1. A petição do Recurso Especial poderá ser protocolada em lugar diverso da Secretaria do Tribunal de origem, se acaso houver protocolo descentralizado, devendo legislação específica estadual ou o regimento interno do tribunal dispor a respeito do assunto. 2. Havendo ato do Tribunal que exclui os recursos dirigidos aos Tribunais Superiores de serem protocolizados no Protocolo Geral das Varas - PROGER das Comarcas do Interior ou Fóruns Regionais, há de se concluir que não existem protocolos integrados no Estado do Rio de Janeiro para efeito de protocolo de petições dirigidas aos Tribunais Superiores, sendo a única opção o protocolo na Secretaria da 2. ${ }^{a}$ instância. Precedentes do STJ. 3. É considerado deserto o recurso especial se a regularização do respectivo preparo foi realizada intempestivamente, em desconformidade com as normas de protocolo interno do TJRJ. 4. Agravo regimental não provido. No mesmo sentido: EDcl nos EDcl no AgRg no AREsp 270732/SP; EDcl nos EDcl no AREsp 84156/SP; AgRg no AREsp 305152/RS; AgRg nos EDcl no REsp 1350235/SP.
} 
protocolo, considerando-se a data da postagem do recurso, trará mais eficiência ao sistema recursal.

\subsubsection{Quanto ao requisito da regularidade formal}

O formalismo exacerbado no juízo de admissibilidade também se verifica no que se refere ao requisito da regularidade formal, em várias situações.

\subsubsection{Exigência de certidão de intimação da decisão agravada}

O formalismo exagerado ocorre quando o tribunal obsta o conhecimento do recurso extraordinário por faltar, na petição de interposição do recurso, a data em que ela teria sido registrada no protocolo da secretaria do tribunal a quo, ou mesmo quando o carimbo do protocolo se mostra ilegível, impedindo a aferição da tempestividade, constituindo óbice, inclusive, o conhecimento do segundo recurso (agravo) interposto contra o indeferimento respectivo, por incompleta a formação do instrumento. Dentre as justificativas, tem-se a de que constitui ônus do recorrente a comprovação da tempestividade do recurso.

No entanto, conforme pondera José Carlos Barbosa Moreira, não é o recorrente quem carimba o protocolo, e não parece justo fazê-lo arcar com a consequência de defeito do serviço judiciário, uma vez que isso lhe falta ao controle. Somente é concebível a existência de ônus praticado pela própria parte, não podendo impor-lhe o ônus de atos praticados pelo próprio Judiciário. Chegou-se, inclusive, a negar conhecimento por faltar a certidão do órgão a quo. Esses fatos denotam o extremo formalismo, pois o tribunal deixa de conhecer de recurso que sabe ser tempestivo apenas em razão do modo que se deu o cumprimento do requisito. ${ }^{419}$

O autor discorre que é relativo o conceito de legibilidade, uma vez que depende da acuidade visual do observador, bem como da atenção com que examina, sendo possível qualificar de legível ou ilegível determinado documento. O que se quer dizer com o carimbo deve ser “absolutamente legível”? Que deve ser lido por qualquer pessoa sob luz

${ }^{419}$ BARBOSA MOREIRA, 2007b, p. 276. 
fraca ou forte, enxergue bem ou mal? E se quem examina precisar de lentes corretoras e não as esteja usando na ocasião do exame do documento?

Argumenta, ainda, que o ônus da prova da intempestividade deveria recair sobre o recorrido. Quando o órgão judicial estiver diante de um ponto duvidoso, havendo meio de esclarecê-lo, sem detrimento para qualquer das partes e sem prejuízo sensível para o trâmite do processo, impõe-se a dissipação da dúvida, mesmo porque esta é uma das razões de se atribuírem os poderes instrutórios ao juiz, que podem, inclusive, ser exercidos de ofício. Além disso, a experiência forense indica que a maioria dos recursos é interposta dentro do prazo que a lei lhes atribui. A presunção há de ser favorável ao recorrente, com base na regra de experiência comum subministrada pela observação do que ordinariamente acontece, conforme prescreve o artigo 335 do ordenamento processual. ${ }^{420}$

No nosso entendimento, se a parte não contribuiu para com a dúvida da tempestividade, visto que não detém nenhum poder de determinar a legibilidade do carimbo utilizado por funcionários do Poder Judiciário, não pode ser prejudicada com a inadmissibilidade do recurso, pois a obrigação de fornecer os meios necessários ao recebimento dos recursos é do próprio serviço público, permanecendo o recorrente em posição de hipossuficiente.

Dessa forma, se o Estado, por meio do Poder Judiciário, coloca o recorrente em estado de hipossuficiência, não é justo, e demonstra formalismo exacerbado negar-lhe seguimento a recurso, por mera suposição de intempestividade, quando a situação foi criada pelo próprio poder público.

\subsubsection{Comprovação da representação processual}

Da leitura do caput do artigo 13 do Código de Processo Civil que prescreve, "Verificando a incapacidade processual ou a irregularidade da representação das partes, o juiz, suspendendo o processo, marcará prazo razoável para ser sanado o defeito”, entendese que a disposição abrange mais de uma hipótese, ou seja: a incapacidade de parte, não suprida pela presença do respectivo assistente ou representante legal, irregularidade nesse

${ }^{420}$ BARBOSA MOREIRA, 2007b, p. 276-277. 
próprio suprimento, defeito da representação judicial, sendo este último, falta de procuração outorgada ao advogado. ${ }^{421}$

Para José Carlos Barbosa Moreira, o artigo 13, primeira parte, do Código de Processo Civil não restringe o momento do processo, ou grau de jurisdição, em que se dá o defeito da representação. Quando menciona “juiz”, significa o “órgão judicial”, de qualquer instância, onde tramita o feito. Assim, constitui restrição ilegítima a distinção entre instâncias “ordinárias” e os recursos especial e extraordinário, de outro, na incidência do mencionado artigo $13 .{ }^{422}$

O Superior Tribunal de Justiça inseriu na Súmula da Jurisprudência Predominante o Enunciado n. ${ }^{\circ}$ 115: "Na instância especial é inexistente recurso interposto por advogado sem procuração nos autos”. O Supremo Tribunal Federal tem o mesmo entendimento no que diz respeito ao recurso extraordinário. No entanto, na opinião de José Carlos Barbosa Moreira, não se visualizam na lei essas diferenças de tratamento, devendo a oportunidade dada pelo artigo 13 ser aberta em qualquer fase do processo, e a decisão de não conhecer do recurso ficar reservada para o caso de esgotar-se in albis o prazo fixado pelo tribunal para a regularização, para que não se configure mais uma restrição ilegítima ao conhecimento de recurso. ${ }^{423}$

Se a lei processual admite a regularização da representação processual, é demonstração de formalismo excessivo excluir as Cortes mais elevadas do País, as quais deveriam dar o exemplo, oferecendo oportunidade para que a parte corrija a omissão e faça a juntada do instrumento de procuração para a correção do defeito de representação.

Considerar o recurso inexistente, conforme sumulado pelo Superior Tribunal de Justiça, por ter sido interposto por advogado sem procuração, constitui formalismo, bem como demonstra afronta a dispositivo de lei complementar, conforme artigo 13 do Código de Processo Civil, visto que a permissão de correção do defeito de representação não exclui as Cortes Superiores, pois é válida para qualquer grau de jurisdição.

Ainda, faz-se necessário ressaltar que cabe às Cortes excepcionais o controle da aplicação correta da lei infraconstitucional, sendo incompatível com o seu dever a sua

${ }^{421}$ BEDAQUE, José Roberto dos Santos. Código de Processo Civil interpretado. MARCATO, Antonio Carlos (Org). São Paulo: Atlas, 2004. p. 80 Nesse mesmo sentido, o Acórdão do REsp 102.423, de 21.09.1998, em que foi relator o Ministro Sálvio de Figueiredo Teixeira: “A regra do art. 13 do CPC não cuida apenas de representação legal e da verificação da incapacidade processual, mas também da possibilidade de suprir omissões relativas à incapacidade postulatória” (DJ 21.09.1998, p. 168).

${ }_{422}$ BARBOSA MOREIRA, 2007b, p. 280.

${ }^{423}$ Iibidem, p. 280-281. 
própria exclusão, ou seja, a lei deve ser válida para todos, não somente para os jurisdicionados, como também para os aplicadores do direito, em todas as instâncias.

\subsubsection{Quanto ao não conhecimento do recurso em razão do esquecimento do advogado em assinar as razões do recurso ou assinar digitalmente}

Há restrição ilegítima quando o tribunal nega conhecimento ao recurso pelo mero fato de não estarem assinadas as razões, uma vez que perfeitamente suprível. Além disso, não existe amparo legal quanto à distinção de instâncias que se costuma fazer para sustentar que o suprimento é viável até o segundo grau de jurisdição, mas deixa de sê-lo nos recursos especial e extraordinário. Inexiste texto legal que demonstre em termos explícitos ou implícitos essa diferença de tratamento entre tribunais. ${ }^{424}$

A Ministra Nancy Andrighi, na admissibilidade do Recurso Especial n. ${ }^{\circ}$ 1.442.887/BA. ocorrido em 06.05.2014, negou-lhe conhecimento em razão de a assinatura do advogado ter sido feita por meio de escaneamento eletrônico, alegando que esse tipo de assinatura, sem qualquer regulamentação, é arriscado na medida em que ela pode ser feita por qualquer pessoa que tenha acesso ao documento original e inserida em outros documentos. Afirma que não há garantia de autenticidade e que o princípio da instrumentalidade das formas invocado pelos recorrentes deve encontrar limites exatamente no princípio da segurança jurídica, e que o disposto no artigo 365 do CPC não legitima a utilização da assinatura digitalizada para a interposição de recursos no âmbito do Superior Tribunal de Justiça. ${ }^{425}$

Em nosso sentir, se a parte interessada invocou o princípio da instrumentalidade das formas e confirmou a autenticidade da assinatura do advogado, não há razão para a denegação do conhecimento do recurso, uma vez que a dúvida quanto a autenticidade da assinatura foi esclarecida, tratando-se de formalismo exacerbado o não conhecimento do recurso.

\footnotetext{
${ }^{424}$ BARBOSA MOREIRA, 2007b. p. 278.

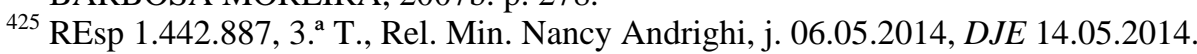




\subsubsection{Razões apresentadas após a interposição do recurso}

Há controvérsia tanto doutrinária quanto jurisprudencial no tocante à regra contida no artigo 514 do Código de Processo Civil de as razões serem juntadas posteriormente à petição de interposição do recurso, porém dentro do prazo estipulado no artigo 508, havendo duas correntes que se contrapõem.

A primeira corrente liderada por José Manuel de Arruda Alvim e Flávio Cheim Jorge não admite que as razões sejam juntadas posteriormente, e justificam que houve preclusão consumativa. ${ }^{426}$

Corrente diversa lidera José Roberto dos Santos Bedaque, para quem, se os fundamentos deduzidos pelo recorrente não vierem com a petição de interposição, mas forem apresentados dentro do prazo recursal, a irregularidade deixou de existir, porque foram sanados a tempo, devendo o vício, portanto, ser desconsiderado, mesmo porque o recorrido não sofreu nenhum prejuízo, devendo ser intimado para responder ao recurso após a regularização, conforme artigos 244, 249, § 1. ․ e 250, parágrafo único, do Código de Processo Civil. ${ }^{427}$

Explica o processualista que preclusão consumativa é a perda da faculdade de praticar o ato. Se o seu exercício foi consumado, não há como repeti-lo. A situação é diversa, quando houve a possibilidade de corrigir vícios formais do ato processual. A eliminação de vício, se realizada no prazo estabelecido para a prática do ato processual defeituoso, deve ser admitida sem qualquer restrição, pois não obstaculiza o regular desenvolvimento do processo, não acarretando dano às partes. ${ }^{428}$

Filiamo-nos a esta última corrente pois entendemos que, se o vício formal foi sanado antes do vencimento do prazo destinado à prática do ato, deve ser ele considerado pois inexistiu qualquer prejuízo para qualquer das partes.

\footnotetext{
${ }^{426}$ A interposição do recurso gera preclusão consumativa, não sendo mais possível emendá-lo ou substituí-lo (CHEIM JORGE, 2002. p. 180); ARRUDA ALVIM, José Manuel. Manual de direito processual civil. 3. ed. São Paulo: RT, 1994. v. 1, p. 432.

${ }^{427}$ BEDAQUE, 2003, p. 440-441.

${ }^{428}$ Ibidem, p. 441-442.
} 


\subsubsection{Quanto ao requisito preparo}

\subsubsection{Preenchimento das guias de preparo e comprovação posterior}

Anteriormente à Lei n. ${ }^{0}$ 9.756/1998, as custas eram pagas posteriormente à interposição do recurso, visto que os autos eram remetidos ao contador e somente após a apresentação da conta elaborada é que o recorrente era intimado para esse pagamento, e teria o prazo de dez dias, fixados por lei, para efetuá-lo, sob pena de deserção. ${ }^{429} \mathrm{Na}$ nova sistemática, a parte deverá comprovar o preparo no ato da interposição do recurso com a juntada das guias e seus respectivos recolhimentos.

No tocante a esse aspecto, Flávio Cheim Jorge levanta a dúvida quanto a possibilidade de se interpor o recurso e, a seguir, comprovar o pagamento do preparo, mas, ainda dentro do prazo de interposição do recurso. Exemplificando: interpor o recurso no $5 .^{\circ}$ dia e comprovar o pagamento das custas até o $15 .{ }^{\circ}$ dia. ${ }^{430}$ Agrupam-se duas correntes doutrinárias: a primeira é a dos doutrinadores que defendem que, se o recorrente adiantouse em propor o recurso, poderá comprovar o recolhimento das custas posteriormente, desde que o faça até o último dia previsto para a interposição daquele recurso respectivo.

Nesse sentido, Cândido Rangel Dinamarco salienta que o Código de Processo Civil adotou a regra do preparo imediato, cujo comprovante deverá acompanhar a petição de interposição, porém entende que, se o preparo não tiver sido feito até então, a comprovação pode ser admitida até o último dia do prazo para recorrer, sob pena de preclusão. A juntada da guia de recolhimento, desde que paga dentro do prazo, pode ocorrer depois, excepcionalmente, mediante justificativa razoável, em prazo que o juiz concederá ao recorrente. ${ }^{431}$ Na mesma linha de raciocínio, José Carlos Barbosa Moreira critica o apego à letra do art. 511, caput, na redação dada pela Lei n. ${ }^{\circ}$ 9.756, de 17.01.1998, entendendo que o essencial é que o recurso seja preparado dentro do prazo de interposição, e, se isso ocorrer, não vê razão para impedir que a comprovação seja feita posteriormente. ${ }^{432}$

\footnotetext{
${ }^{429}$ PINTO, 2004. p. 73.

${ }^{430}$ CHEIM JORGE, 2009, p. 190.

${ }^{431}$ DINAMARCO, Cândido Rangel. A reforma do Código de Processo Civil. 2. ed. São Paulo: Malheiros, 1995. p. 164.

${ }^{432}$ BARBOSA MOREIRA, 2007b, p. 282.
} 
A outra corrente entende que houve preclusão consumativa, ou seja, o preparo teria que ter sido comprovado no ato da interposição do recurso. ${ }^{433}$ A jurisprudência dominante do Superior Tribunal de Justiça repele a possibilidade de que o recorrente comprove, posteriormente à interposição do recurso, o recolhimento das custas, mesmo que feita tempestivamente, ou seja, se o comprovante de recolhimento das custas do preparo não acompanhou o recurso, este será considerado “deserto”. Nesse sentido, Nelson Nery Junior e Rosa Maria de Andrade Nery afirmam: “Caso se interponha o recurso e só depois se junte a guia de preparo, terá ocorrido preclusão consumativa, ensejando o não conhecimento do recurso por ausência ou irregularidade do preparo.”^34

Nesses casos, o preparo é visto como barreira para a pletora de recursos que assoberba o Judiciário, e não como tributo que deveria ser cobrado como os demais tributos que, em caso de inadimplemento ou recolhido intempestivamente, incorrem em multas e outros consectários (juros e correção monetária), e não exigido como condição de reexame de decisões judiciais. Destarte, a deserção não se compatibiliza com os ideais de justiça, com o perecimento de um direito material da parte, em razão de falta de pagamento de uma quantia que, muitas vezes, é irrisória. ${ }^{435}$

Por seu turno, José Roberto dos Santos Bedaque entende que, se o recorrente fizer o respectivo recolhimento dentro do prazo previsto no Código de Processo Civil, deve-se considerar sanado o vício existente no momento da interposição do recurso, uma vez que não há possibilidade de prejuízo a qualquer das partes, desconsiderando-se a irregularidade

\footnotetext{
${ }^{433}$ Nesse sentido: PINTO, 2004. p. 73. "Com a interposição do recurso consuma-se o prazo (preclusão consumativa), não havendo que se falar em saldo remanescente de prazo para que o recurso seja emendado ou aditado e, tampouco, efetuado o seu preparo. Trata-se de preclusão consumativa, que faz esgotar o prazo recursal no momento da interposição"; NERY JR., Nelson et NERY, Rosa Maria de Andrade. Código de Processo Civil comentado. São Paulo: RT, 2009. p. 882. "Os atos de recorrer e preparar o recurso formam um ato complexo, devendo ser praticados simultaneamente, na mesma oportunidade processual como manda a norma sob comentário (art. 511 CPC).”

${ }^{434}$ NERY JR. et NERY, p. 882. No mesmo sentido: ASSIS, 1999. p. 45.

${ }^{435}$ Donaldo Armelin argumenta que: "Para se inadmitirem recursos a teor de deserção concretizada, alguns vieses formalistas provocaram decisões em que foi desconsiderado preparo efetivado em banco autorizado a receber tributos da União, e não na Caixa Econômica Federal, como determinava a lei, muito embora comprovado o recolhimento aos cofres da União, na mesma data, e, pois tempestivo, da importância do preparo devido. Evidentemente são situações isoladas, mas que demonstram como o preparo pode ser utilizado como obstáculo para o exercício de um direito constitucionalmente assegurado - o direito de recorrer” (1999. p. 202). No mesmo sentido, Leonardo Greco aponta: “A subordinação do exercício da jurisdição ao prévio recolhimento das custas é um resíduo do estado patrimonial. A finalidade do processo não é arrecadar receita para o Estado, mas prestar a jurisdição. O Estado tem o direito de cobrar por esse serviço essencial da tutela dos direitos dos cidadãos à prévia satisfação do seu interesse arrecadatório ou de negar a jurisdição por falta de preparo. O tributo, o Estado tem todos os meios legais para cobrar, mas não pode condicionar o exercício do dever de exercer a jurisdição a uma prestação econômica por parte do jurisdicionado" (Estudos de direito processual. Campos dos Goitacazes: Ed. Faculdade de Campos, 2005. p. 303. Coleção José do Patrocínio).
} 
consistente na falta de juntada da guia de preparo com a petição do recurso. Salienta que não se verifica o fenômeno da preclusão consumativa, visto que a parte não está recorrendo novamente, ato já praticado e cuja eficácia pretende seja mantida. Ao apresentar a guia de preparo no prazo previsto para a interposição, simplesmente corrige, dentro do prazo, uma falha na interposição da petição recursal. Significa que se o pagamento das custas foi realizado no prazo previsto para a interposição do recurso, sanado está o defeito constatado no ato de interposição. ${ }^{436}$

Defende o processualista que conclusão diversa é fruto de um exagerado formalismo, não compatível com a moderna ciência processual, preocupada muito mais com resultados do que com a técnica. A técnica e a forma visam sempre possibilitar que o ato, em si mesmo considerado, e o processo visto de forma global alcancem os objetivos desejados pelo sistema.

Discorre, ainda, que o objetivo maior do sistema é a obtenção, pela via estatal de solução das controvérsias, da adequada tutela jurisdicional e que o duplo grau proporciona o reexame das decisões, contribuindo para alcançar tais resultados, e que a regularização de atos recursais deve ser admitida sempre que possível. ${ }^{437}$

Em que pese o nosso respeito aos posicionamentos contrários, entendemos que a finalidade precípua do preparo é ressarcir aos cofres públicos as despesas processuais. Além disso, se o recorrente recolhe aos cofres públicos o valor do preparo no prazo recursal, cumpriu a sua obrigação. O fato de protocolar o recurso e posteriormente comprovar o recolhimento do preparo não modifica o fato de que o cumprimento da obrigação foi tempestivo, mesmo porque não há qualquer prejuízo seja ao erário, seja para qualquer das partes, o que torna formalismo excessivo a não aceitação da comprovação do preparo posteriormente ao protocolo do recurso, mesmo dentro do prazo recursal.

\subsubsection{Quanto a não aceitação do pagamento das custas via internet}

Outro aspecto a ser analisado quanto ao requisito preparo é a questão da aceitação do pagamento das custas processuais via internet. A 4. ${ }^{\text {a }}$ Turma do Superior Tribunal de

\footnotetext{
${ }^{436}$ BEDAQUE, 2003, p. 440-441
}

${ }^{437}$ Ibidem, p. 445. 
Justiça rejeitou recurso especial em razão de as custas terem sido pagas eletronicamente e não ter sido comprovada a certificação física. ${ }^{438}$

Posicionamo-nos, do mesmo modo que José Miguel Garcia Medina e Teresa Arruda Alvim Wambier, discordando dessa orientação do Superior Tribunal de Justiça, em razão de o artigo 511 do Código de Processo Civil não fazer essa exigência. Justificam os autores mencionados que essa exigência também colocaria em dúvida a autenticidade dos recibos impressos pela própria instituição financeira. “Além disso, tal orientação parte do pressuposto de que a parte age de má-fé, quando, a rigor, a boa-fé se presume, e a má-fé deve ser provada." 439

O processo eletrônico está sendo implantado em todo o País, bem como o Superior Tribunal de Justiça já regulamentou o seu processamento por meio da Resolução n. ${ }^{\circ}$ 14/2013, e o Supremo Tribunal Federal, pela Resolução n. ${ }^{\circ}$ 427/2010, já consolidado com as alterações previstas nas Resoluções n. ${ }^{\circ} 442 / 2010 ;$ n. ${ }^{\circ} 476 / 2011 ; n .^{0}$ 489/2012 e n. ${ }^{\circ}$ $490 / 2012$.

\footnotetext{
${ }^{438}$ Conforme mencionado por Marcio Carvalho Faria (2011, p. 236) e confirmado no site do STJ, a publicação de 02.06.2009, do acórdão do REsp 1.103.021/DF, cujo teor ora se transcreve: "Comprovante de pagamento de custas retirado da internet só é válido com certificação de origem. Não é válida a apresentação nos autos de comprovante de preparo de recurso especial extraído da internet. A decisão é da Quarta Turma do Superior Tribunal de Justiça (STJ), que negou agravo (tipo de recurso) interposto por uma cidadã do Distrito Federal. A Turma, por maioria, seguiu o entendimento do relator, Ministro Luís Felipe Salomão, o de que para serem admitidos no processo, os documentos retirados dos sítios eletrônicos devem ter a certificação de sua origem. Anteriormente, o Ministro Salomão havia negado o seguimento do recurso especial da cidadã por entender que os documentos extraídos da internet não são dotados de caráter oficial hábil a comprovar o pagamento. Ela agravou a decisão para que o caso fosse analisado por todos os ministros da Quarta Turma. Em sua defesa, ela alegou que houve o pagamento do preparo na perfeita conformidade legal e regimental e que os comprovantes foram recolhidos a partir do sítio eletrônico do Banco do Brasil, com os respectivos códigos de certificação e autenticação pelo Sistema de Informações do Banco do Brasil (SISBB). Sustentou, ainda, que não existe dispositivo legal proibindo o recolhimento pelos meios postos à disposição pelo banco e que exigir mais do que isso constituiu imposição de condição processual impossível de ser atendida pelo jurisdicionado, em flagrante afronta ao artigo 5. ${ }^{\circ}$, incisos II, XXXV, LV, da Constituição Federal. O Ministro Salomão manteve sua posição, destacando que, embora seja admitida a juntada de documentos e peças extraídas da internet, é necessária a certificação de sua origem. Para ele, a cidadã não conseguiu comprovar adequadamente o pagamento das custas e do porte de remessa e retorno do recurso especial. De acordo com o relator o documento apresentado não continha o cabeçalho e o rodapé que devem estar presentes neste tipo de documentos extraídos da internet, o que indica ter a cidadã se valido de recursos de um editor de textos. 'Ademais, a conferência da autenticidade desses documentos exigiria uma instrução probatória, incompatível com o artigo 511 do Código de Processo Civil', afirmou o ministro. O relator ressaltou, ainda, que, no que concerne à afirmação de que não há meios diversos da internet para comprovar o pagamento da GRU, afigura-se totalmente descabida, visto que, por intermédio de pagamento nos caixas do Banco do Brasil, é possível conseguir o comprovante idôneo, com os dados registrados em papel timbrado da instituição financeira. Segundo ele, trata-se, portanto, de incumbência acessível a qualquer jurisdicionado (REsp 1103021). Disponível em:

$<$ http://www.stj.jus.br/portal_stj/publicacao/engine.wsp?tmp.area=398\&tmp.texto=92243>. Acesso em: 3 dez. 2011.

${ }^{439}$ MEDINA et WAMBIER, 2011, p. 104-105.
} 
A Resolução n. ${ }^{\circ}$ 1, de 18.01.2011, do Superior Tribunal de Justiça estabelece as regras de preenchimento da guia GRU, que pode ser preenchida on-line por meio de acesso ao sítio do Tribunal, bem como das custas relativas ao porte e remessa dos autos.

A Resolução não prevê onde deva ser realizado o pagamento, mas, no nosso entendimento, se a guia pode ser executada on-line, não tem sentido que o seu pagamento não possa ser realizado também on-line, mesmo porque o Poder Judiciário atualmente utiliza os meios eletrônicos para diversos atos, e com a implantação do procedimento eletrônico fica sem sentido a não aceitação do pagamento das custas pelos meios eletrônicos, pois, em caso de dúvida, a parte poderá ser intimada para prestar esclarecimentos, e, caso fique comprovado que agiu ilicitamente, ficará incursa nas penalidades previstas para o litigante de má-fé, previsto nos incisos II e V do artigo 17 e artigo 18 do Código de Processo Civil.

\subsubsection{Quanto ao preenchimento da GRU}

O Superior Tribunal de Justiça, mediante a Resolução n. . 12/2005, fixou os valores relativos ao "porte de remessa e retorno” dos autos para cada Estado, e notícia extraída do seu site determina que o número do processo recorrido conste da GRU, conforme a seguir se transcreve:

\footnotetext{
Número do processo deve constar da guia de recolhimento da União

Para o pagamento do porte de remessa e retorno dos autos no âmbito do Superior Tribunal de Justiça (STJ), é necessário que conste na guia de recolhimento da União (GRU) o número do processo a que ela se refere. O entendimento da Segunda Turma do STJ é que, em caso contrário, pode-se considerar o recurso deserto, ou seja, extinto por falta de preparo.

A questão foi definida em um recurso em mandado de segurança de Minas Gerais. Uma empresa mineira subsidiária da Net Serviços de Comunicação, multioperadora de TV por assinatura no Brasil, tentava ver apreciado pelo tribunal superior recurso em mandado de segurança no qual discute multa aplicada em um processo administrativo do Procon. A instituição apurava o fato de a operadora não disponibilizar, em toda a sua área de cobertura, o pacote de programação standard, mas apenas os pacotes master e advanced, mais caros. O mérito do pedido, contudo, sequer chegou a ser apreciado pelo STJ. O processo não foi conhecido porque não houve o adequado preparo do processo. Conforme ressalta o relator, ministro Humberto Martins, a Resolução n. ${ }^{\circ} 12$, que fixa o valor a ser recolhido para o pagamento do porte de remessa e retorno dos autos no âmbito do Superior Tribunal de Justiça, dispõe que os valores constantes desta Tabela devem ser recolhidos no Banco do Brasil mediante preenchimento de Guia de Recolhimento da União (GRU), UG/Gestão 050001/00001, Código de Recolhimento 18827-1- Porte de remessa e retorno dos autos, podendo ser acessada no endereço eletrônico <www.stj.gov.br>,
} 
contas públicas, guia de recolhimento da união e anotando-se o número do processo a que se refere, juntando-se comprovante aos autos.

Segundo o ministro, a jurisprudência do tribunal é unânime ao exigir o exato preenchimento da guia de preparo a ser paga no Banco do Brasil, inclusive com a correta inscrição do número de referência. No caso apreciado, não há tal rubrica. O entendimento unânime da Segunda Turma é que deve constar na GRU o número do processo ao qual ela se refere sob pena de ser considerado deserto o recurso por falta de pagamento da guia. ${ }^{440}$

Entre os anos de 2004 e 2011, o Superior Tribunal de Justiça editou nove resoluções disciplinando o modo de preenchimento da GRU, ora alterando o valor das taxas, ora o código a ser preenchido, ora determinando a necessidade e a forma de anotação do número do processo. ${ }^{441}$

Atualmente, encontra-se em vigor a Resolução n. ${ }^{0}$ 01/2011, que dispõe sobre o pagamento de custas judiciais e porte de remessa e retorno de autos no âmbito do Superior Tribunal de Justiça.

Também o Supremo Tribunal Federal editou várias resoluções, sendo a última de n. ${ }^{\circ} 462 / 2011$.

O Superior Tribunal de Justiça outrora considerava inválido o preenchimento à mão do número do processo na GRU, pelo recorrente, justificando que não haveria como provar que essa guia não foi utilizada, indevidamente, em outros processos.

O Ministro Paulo de Tarso Sanseverino, no relatório do AgRg no REsp 1169129/RJ, assim justificou:

[...] o acesso à tutela jurisdicional deve ser regulado pela clareza das regras procedimentais, cuja principal finalidade é garantir a segurança jurídica e a isonomia processual entre as partes envolvidas no processo, evitando o uso do expediente fraudatório da reprodução de guias de processos diversos em um mesmo fólio. ${ }^{442}$

Vários julgados se espelham no julgamento do AgRg no REsp n. ${ }^{\circ}$ 924.942, em que foi relator o Ministro Mauro Campbell Marques, no qual se decidiu considerar deserto o recurso que fosse acompanhado da guia de recolhimento das custas em desacordo com a

\footnotetext{
${ }^{440}$ Disponível em: http://www.stj.jus.br/portal_stj/publicacao/engine.wsp?tmp.area=398\&tmp.texto=92243>. Acesso em: 3 dez. 2011.

${ }_{441}^{44}$ FARIA, Marcio Carvalho. 2011, p. 238.

http://www.stj.jus.br/SCON/jurisprudencia/toc.jsp?tipo_visu

Disponível em:

$\mathrm{b}=\mathrm{ACOR} \& \mathrm{p}=$ true $\& \mathrm{t}=\& \mathrm{l}=10 \& \mathrm{i}=10>$. Acesso em: $5 \mathrm{dez} .2011$.
} 
com a Resolução n. ${ }^{\circ}$ 12/2005, sendo que a ausência do número do processo na GRU invalidava o recolhimento. ${ }^{443}$

São tantas as Resoluções e notícias quanto ao preenchimento das guias de preparo que deveria ocorrer uma consolidação de todas, com normatização clara a respeito do correto preenchimento das guias.

O que se denota é que o Superior Tribunal de Justiça presume a má-fé dos recorrentes, quando deveria presumir a boa-fé, visto que pune com a pena de deserção toda e qualquer anormalidade no preenchimento das guias de preparo, sem dar qualquer oportunidade ao recorrente para comprovar o equívoco.

Excetuando-se os casos em que comprovadamente houve má-fé, na maioria das vezes a importância foi recolhida aos cofres públicos, cumprindo o objetivo de pagamento pela utilização do Judiciário e ressarcimento das despesas de porte de remessa e retorno, sendo injusta a aplicação da pena de deserção, o que demonstra excesso de formalismo, constituindo-se mera defesa defensiva.

No nosso entender, a punição somente deveria recair sobre o recorrente que, comprovadamente, agiu com má-fé, como é o caso do REsp n. ${ }^{\circ}$ 986443/RJ, j. 06.03.2008, em que foi relatora a Ministra Eliana Calmon, ao constatar que a guia havia sido aproveitada em outro feito, condenou o advogado, subscritor do recurso, ao pagamento de multa fixada em $1 \%$ e indenização, nos termos do art. 18, § 2. ${ }^{\circ}$, do CPC, equivalente a 3\% do valor atualizado da causa, por ter agido com má-fé. ${ }^{444}$

\footnotetext{
${ }^{443}$ AgRg no REsp 924.942. Ementa: Processual civil. Recurso especial. Porte de remessa e retorno dos autos. Exigências contidas nas resoluções do STJ aplicáveis à espécie. Deserção verificada. Ausente o número do processo a que se refere o recolhimento. Preparo efetivado em 20.06.2005. Indicação errônea do código da receita. Incidência da Resolução n. 12/2005.

1. A partir da edição da Resolução n. 20/2004, além do recolhimento dos valores relativos ao porte de remessa e retorno em rede bancária, mediante preenchimento da Guia de Recolhimento da União (GRU) ou de Documento de Arrecadação de Receitas Federais (DARF), com a anotação do respectivo código de receita e a juntada do comprovante nos autos, passou a ser necessária a indicação do número do processo respectivo.

2. Constata-se que, in casu, não foi anotado o número do processo a que se refere o documento de arrecadação de receitas federais, juntado à fl. 227 dos autos, bem como houve anotação errônea do código de receita.

3. Tendo sido efetuado o preparo em 20.06.2005, incide o disposto na Resolução n. 12/2005, não merecendo reparo a decisão agravada.

4. Agravo regimental não provido. No mesmo sentido se seguiram: AgRg no Ag 1394190/SC; RCDESP no Ag 1374521/SP; AgRg no REsp 1155473/SP; AgRg no REsp 1169129/RJ; EDcl no AgRg no Ag 1342834/RS; AgRg no Ag 1299448 / SP; EREsp 820539/ES; AgRg no REsp 821380/RJ.

${ }^{444}$ É o que ocorreu no REsp 986443/RJ, j. 06.03.2008. “Inicialmente, verifico que o presente recurso especial não merece ser admitido. E isto porque a GRU juntada aos autos (fl. 180) foi nitidamente aproveitada de outro feito, de n. ${ }^{\circ}$ 2003.51.04.0019020, tendo como parte autora Edmyr Orioli, contendo rasuras sobrepostas a essas informações e a inserção, a caneta, dos dados dos presentes autos”; com condenação do advogado pela litigância de má-fé: "condeno o subscritor do recurso de fls. 169/177, ao pagamento de multa que ora
} 
No julgamento do EREsp n. ${ }^{\circ}$ 1090683/MG ocorrido em 09.06.2011, em que foi relator o Ministro Teori Albino Zavaski junto à Corte Especial - CE, com a aquiescência dos Srs. Ministros Castro Meira, Arnaldo Esteves Lima, Humberto Martins, Maria Thereza de Assis Moura, Sidnei Beneti, Mauro Campbell Marques, Cesar Asfor Rocha, Felix Fischer, Gilson Dipp, Eliana Calmon, Laurita Vaz e João Otávio de Noronha, houve mudança desse posicionamento, entendendo que não é possível negar seguimento ao recurso especial sob a alegação de que o número do processo indicado na GRU foi preenchido à mão, na hipótese em que não se constata erro no número de referência aposto manualmente, nem nas demais informações obrigatórias. Pois exigir a impressão do número do processo configura excesso de formalismo, além de não encontrar amparo nas normas processuais, que são pautadas pelo princípio da instrumentalidade e da informalidade, nem nas normas editadas pelo Superior Tribunal de Justiça que tratam do preenchimento dessas guias. $^{445}$

Esse acórdão abre precedente para a diminuição da jurisprudência defensiva no tocante à aceitação de pequenas irregularidades quanto ao preenchimento das guias de recolhimento das custas, uma vez que o valor foi recolhido aos cofres públicos, estando cumprido o seu objetivo.

Partindo-se das premissas a) da complexidade da exigência do preparo e b) da aplicação da regra do $\S 2 .^{\circ}$ do artigo 511, nos casos de recolhimento insuficiente, que dá oportunidade ao recorrente de sua complementação no prazo de cinco dias, deve também haver coerência com aplicação da mesma regra, proporcionando ao recorrente a possibilidade de esclarecimento e comprovação do efetivo recolhimento ao erário, na hipótese de preenchimento irregular da guia de preparo, uma vez que são várias as instruções quanto ao preenchimento, como também o é a sua interpretação pelos próprios Ministros do Superior Tribunal de Justiça.

Essas exigências constituem um apego ao formalismo excessivo, utilizado de forma defensiva pelos Tribunais Superiores, que se encontram abarrotados de processos. No entanto, essas exigências fogem da finalidade precípua que leva o indivíduo a procurar o

fixo em $1 \%$ (um por cento) do valor atualizado da causa, bem como ao pagamento de indenização, nos termos do art. 18, § 2. ${ }^{\circ}$, do CPC, equivalente a 3\% (três por cento) do valor atualizado da causa”.

${ }^{445}$ EREsp 1090683/MG. Ementa: Processual civil. Porte de remessa e retorno. GRU. Indicação do número do processo. Preenchimento a mão. Possibilidade. 1. O preenchimento manual do campo correspondente ao número do processo não ofende as exigências formais da Guia de Recolhimento da União - GRU, referente ao pagamento do porte de remessa e retorno, previstas na Resolução n. 12/2005/STJ. 2. Embargos de divergência providos. 
Judiciário objetivando a pacificação de um conflito originado no direito material, o que fere o princípio do devido processo legal. 


\section{OS PODERES DO RELATOR}

O legislador foi gradualmente aumentando os poderes do relator, permitindo-lhe resolver questões formais relativas aos recursos, as quais anteriormente eram de competência do órgão colegiado. Tal aumento de poder objetiva decidir mais rapidamente os recursos, como forma de mitigar a crise nos tribunais. No entanto, o excesso de rigor praticado pelos relatores no juízo de admissibilidade quanto aos requisitos formais resulta numa jurisprudência defensiva que impede a análise do mérito recursal.

Segundo lições de Cândido Rangel Dinamarco, o vigente Código de Processo Civil, herdeiro das práticas estabelecidas pelo Código de 1939, inicialmente manteve postura tradicional, dando continuidade à competência dos órgãos colegiados (plenários ou órgãos fragmentários, câmaras etc.) para julgamento dos recursos e causas da competência originária dos tribunais. Em razão disso, o notório e angustiante congestionamento do Poder Judiciário foi conduzindo o processo civil por novos caminhos, que incluem o reforço dos poderes do relator. ${ }^{446}$

A regra tradicional, em âmbito recursal, consagrava o julgamento colegiado, ora pelas Câmaras ou Turmas, ora por colegiados mais numerosos, como as Seções, as Câmaras Reunidas, os Grupos, o Plenário, dependendo da natureza do recurso (ou da ação originária) em julgamento e das normas, legais ou regimentais, relativas à organização judiciária. $^{447}$

Era quase imperceptível a função do relator, restrita à adoção de medidas impulsionadoras da demanda, tais como dar vistas dos autos à parte contrária, submeter o processo ao revisor, deferir juntada de documentos e outras atitudes meramente procedimentais. Agia isoladamente em circunstâncias excepcionais sob o manto da urgência, quando não se podia aguardar a reunião do órgão colegiado, lhe era dado o poder

\footnotetext{
${ }^{446}$ DINAMARCO, Cândido Rangel. O relator, jurisprudência e os recursos. In: NERY JR., Nelson; WAMBIER, Teresa Arruda Alvim (Coord.). Aspectos polêmicos e atuais dos recursos cíveis de acordo com a Lei 9.756/98. São Paulo: RT, 1999. p. 128. No mesmo sentido, Vicente Greco Filho salienta em seu artigo Questões sobre a lei 9.756, de 17 de dezembro de 1998: “A intenção do legislador foi clara: a de facilitar o julgamento de recursos, mediante a estratégia de atribuir ao relator do recurso maiores poderes e de instituir inibições à sua interposição" (In: NERY JR., Nelson; WAMBIER, Teresa Arruda Alvim (Coord.). Aspectos polêmicos e atuais dos recursos cíveis de acordo com a Lei 9.756/98. São Paulo: RT, 1999. p. 599).

${ }^{447}$ CARNEIRO, Athos Gusmão. Poderes do relator e agravo interno - artigos 557, 544 e 545 do CPC. Revista Jurídica, Porto Alegre, ano 48, p. 5, ago. 2000.
} 
provisório de concessão de medidas tidas como necessárias para evitar danos irreparáveis ou de difícil reparação. ${ }^{448}$

Competia aos relatores lançar o relatório nos autos, proferir o primeiro despacho e redigir o acórdão quando vencedor, sendo obrigatória a participação de toda uma turma julgadora em todos os julgamentos nos tribunais, o que gerava uma sobrecarga de trabalho de todos e, consequentemente, contribuía para a demora processual. ${ }^{449}$

O relatório consiste na narrativa imparcial do que consta nos autos, sem que da mesma se possa vislumbrar o voto do seu subscritor a respeito da controvérsia em qualquer de seus pontos, servindo apenas para orientar os demais juízes, evitando a leitura do processo por todos os seus pares, evitando-se assim perda de tempo. O relatório deve conter os elementos essenciais à controvérsia, com o resumo das alegações das partes na defesa de seus direitos, os meios de provas produzidos e a decisão recorrida. ${ }^{450}$

As funções do relator são extremamente importantes e é compreensível que a personalidade do juiz nelas investido e o modo por que as exerça influa poderosamente no julgamento. Elaborar o relatório, principalmente em casos complexos, é tarefa muito delicada. A importância do voto do relator varia em função de inúmeros fatores: além da solidez ou fragilidade de sua fundamentação, há relatores que gozam de maior confiança, o que reflete na probabilidade de que o voto venha a ser acompanhado pelos demais julgadores. Até as relações de afetividade entre o relator e os demais votantes podem assumir relevo considerável, pois um juiz amigo do relator pode talvez hesitar em discordar de um voto em que ele tenha dado mais ênfase, principalmente se a questão for de maior relevância. ${ }^{451}$

Também o presidente do tribunal pode proferir decisões monocráticas, pois estas não se limitam ao relator, como é o caso das suspensões de segurança, entre outras. As decisões monocráticas proferidas nos tribunais somente podem ser consideradas legítimas

\footnotetext{
${ }^{448}$ CAVALCANTE, Mantovanni Colares. Os meios de controle das decisões monocráticas do relator nos tribunais. In: MEDINA et al. (Coord.). Os poderes do juiz e o controle das decisões judiciais. Estudos em homenagem à Professora Teresa Arruda Alvim Wambier. São Paulo: RT, 2008. p. 795.

${ }^{449}$ A solução é apontada por Dinamarco: "Uma decisão singular, proferida em Gabinete, substitui, quando a lei ou regimento o autorizam, os complicados e lentos processamentos perante câmaras, grupos, turmas etc.)" (1999, p. 129).

${ }^{450}$ MENDONÇA LIMA, Alcides de. Recursos cíveis: sistema de normas gerais. São Paulo: Freitas Bastos, 1963. p. 321.

${ }^{451}$ BARBOSA MOREIRA, José Carlos. Notas sobre alguns fatores extrajurídicos no julgamento colegiado.

Revista de Processo. São Paulo, ano 19, n. 75, p. 20-21, 1994d.
} 
se estiverem de acordo com o modelo constitucional, devendo, portanto, respeitar os princípios e garantias constitucionais do processo civil. ${ }^{452}$

Essas decisões monocráticas são passíveis de modificação, pois não são insuscetíveis de controle, uma vez que sempre haverá órgãos colegiados a que se possam submeter tais decisões a fim de que estas sejam reexaminadas, se for o caso, cassadas ou substituídas por outras. O remédio processual que permite o controle das decisões monocráticas proferidas por seus relatores ou seus presidentes se constitui do agravo interno, ${ }^{453}$ que é cabível no prazo de cinco dias.

Diversos precedentes normativos abriram caminho para as sucessivas alterações do Código de Processo Civil, visando a simplificação consistente em reforçar a competência do relator. Diante desse cenário, o legislador foi gradualmente ampliando os poderes do relator, não somente no que diz respeito à decisão monocrática na admissibilidade dos recursos, como também na análise do seu mérito.

Na verdade, a desmedida multiplicação do número de demandas conduziu à edição de leis delegando ao relator a competência para uma apreciação prévia dos requisitos de admissibilidade dos recursos, findando com a outorga de competência para o julgamento singular e, em determinados casos, poderes para julgar o próprio mérito recursal. ${ }^{454}$

A redação original do artigo 557 do Código de Processo Civil permitia que o relator do agravo o indeferisse quando fosse manifestamente improcedente. Posteriormente, a Lei n. ${ }^{\circ}$ 8.038/1990, ao disciplinar o processamento dos recursos nos tribunais superiores, conferiu ao relator poder para decidir sobre pedidos ou recursos que: I - tivessem perdido o seu objeto; II - fossem manifestamente intempestivos, incabíveis ou improcedentes; III contrariassem, nas questões predominantemente de direito, súmula do tribunal.

A seguir, a Lei n. ${ }^{\circ}$ 8.950/1994 veio a incluir a sistemática relativa aos tribunais de superposição no corpo do Código de Processo Civil. Após, a Lei n. 9.139/1995 estendeu aos tribunais em geral a competência ao relator para negar seguimento a qualquer recurso manifestamente inadmissível, improcedente, prejudicado ou contrário à súmula do respectivo tribunal ou tribunal superior. ${ }^{455}$

\footnotetext{
${ }^{452}$ CÂMARA, Alexandre Freitas. O agravo interno no direito processual civil brasileiro. In: MEDINA et al. (Coord.). Os poderes do juiz e o controle das decisões judiciais. Estudos em homenagem à Professora Teresa Arruda Alvim Wambier. São Paulo: RT, 2008. p. 613.

453 Ibidem, p. 614.

${ }^{454}$ CARNEIRO, 2000, p. 5-6.

${ }^{455}$ PUOLI, 2002. p. 196-197.
} 
Na Lei n. ${ }^{\circ}$ 9.139/1995, o legislador deixou à disposição das partes mecanismo para o controle da regularidade das decisões monocráticas, pois a reformulação do parágrafo único do artigo 557 manteve a previsão de recurso contra a decisão unipessoal do relator, agora rotulado como agravo, passando a dispor o $\S 1 .^{\circ}$ do artigo 557 que “da decisão caberá agravo, no prazo de cinco dias, ao órgão competente para o julgamento do recurso". 456

Esse agravo é o principal instrumento para a fiscalização de retidão do julgamento monocrático dos recursos, e é por meio dele que a atividade do relator é controlada e são combatidas as eventuais invasões da competência do colegiado, para preservação da garantia constitucional do juiz natural. ${ }^{457}$

O relator teria visto crescer as suas atribuições, e essa reforma teve o efeito de encontrar compensação no declínio da quantidade de mandados de segurança impetrados contra decisões interlocutórias de primeiro grau. ${ }^{458}$

Na sequência, a Lei n. ${ }^{\circ}$ 9.756/1998 acrescentou novas hipóteses para exame monocrático dos requisitos de admissibilidade e também de mérito dos recursos, não somente quanto aos recursos de tramitação perante os tribunais de segundo grau, como também dos tribunais superiores.

José Carlos Barbosa Moreira salienta que, com a Lei n. ${ }^{\circ}$ 9.756/1998, o legislador, no propósito de abreviar a tramitação dos recursos nos tribunais, ao modificar o caput do artigo 557 e introduzir o $§ 10^{\circ}$ do Código de Processo Civil, reforçou a orientação, já abraçada em diplomas anteriores, de habilitar o relator a decidir por si só, afastando a necessidade do julgamento colegiado, chegando ao extremo de permitir que o relator dê provimento ao recurso, caso a decisão impugnada esteja "em manifesto confronto com jurisprudência dominante do Supremo Tribunal Federal, ou de Tribunal Superior”. 459

No tocante ao agravo de instrumento interposto contra decisão denegatória de seguimento de recurso extraordinário ou de recurso especial conforme o artigo 544, caput, do Código de Processo Civil, a competência para julgá-lo é do relator, e não do colegiado,

\footnotetext{
${ }^{456}$ BONDIOLI, Luiz Guilherme Aidar. Breves notas sobre o controle das decisões monocráticas na instância recursal. Disponível em: <http://www.tex.pro.br/tex/listagem-de-artigos/324-artigos-abr2011/8040-breves-notas-sobre-ocontrole-das-decisoes-monocraticas-na-instancia-recursal>. Acesso em: 27 dez. 2011.

${ }^{457}$ A garantia do juiz natural está prevista no inciso LIII do artigo 5. ${ }^{\circ}$ da Constituição Federal (Ibidem).

458 BARBOSA MOREIRA, José Carlos. Reformas do CPC em matéria de recursos. Temas de direito processual. Oitava série. São Paulo: Saraiva, 2004b, p. 145.

${ }^{459}$ Idem, ibidem, p.150.
} 
cabendo ao relator, por força da Lei n. ${ }^{\circ}$ 9.758/1998, proferir não somente decisão concernente aos requisitos de admissibilidade do recurso não admitido ou do próprio agravo, como ainda decidir o mérito do recurso extraordinário e do recurso especial. Dessa decisão monocrática é admissível um novo recurso de agravo, previsto no artigo 545 também do Código de Processo Civil, hoje apontado como “agravo interno”. 460

O legislador, com essa reforma, procurou ser cauteloso ao ampliar os poderes do relator circunscrevendo o julgamento unipessoal a hipóteses em que o exame do recurso seria simples e objetivo, ou seja, quando o recurso for: a) manifestamente inadmissível (quando faltarem condições mínimas para julgar o mérito do recurso); b) manifestamente improcedente (quando a manifestação recursal for evidentemente infundada); c) manifestamente prejudicado (quando o recurso tiver notoriamente perdido o seu objeto), ou d) recurso ou decisão em confronto com súmula ou jurisprudência dominante (quando a matéria trazida pelo recurso já houver sido suficientemente apreciada por representativos órgãos do Poder Judiciário). ${ }^{461}$

No entanto, as partes dispõem de um instrumento que lhes permite levar as decisões singulares do relator ao órgão colegiado, para que este as reveja, pois é essa a forma de verificar se a decisão proferida pelo relator correspondeu, se está em conformidade com o pretendido pelo órgão colegiado. ${ }^{462}$ Esse mecanismo de revisão da decisão monocrática do relator, que normalmente é denominada de agravo, encontra-se em vários dispositivos, conforme artigos 532, 544, 545 e 557, § 1. ${ }^{\circ}$, do Código de Processo Civil.

Com a edição da Lei n. ${ }^{\circ} 10.352 / 2001$, os poderes do relator foram novamente ampliados, possibilitando a ele não somente a conversão do agravo de instrumento em agravo retido, como também a possibilidade de concessão do chamado efeito ativo do agravo de instrumento, uma vez que acrescentou o inciso III ao artigo 527 do Código de

\footnotetext{
${ }^{460}$ CARNEIRO, 2000, p. 6.

${ }^{461}$ BONDIOLI, 2011. Nesse sentido, acrescenta Acácio Cambi que são estas as hipóteses de negativa de seguimento a recurso (Aspectos polêmicos na aplicação do art. 557 do CPC. In: NERY JR., Nelson; WAMBIER, Teresa Arruda Alvim (Coord.). Aspectos polêmicos e atuais dos recursos cíveis e de outros meios de impugnação a decisões judiciais. São Paulo: RT, 2003. v. 7, p. 14-15).

462 TALAMINI, Eduardo. Recorribilidade das decisões sobre tutela de urgência. In: NERY JR., Nelson; WAMBIER, Teresa Arruda Alvim (Coord.). Aspectos polêmicos e atuais dos recursos cíveis e de outras formas de impugnação às decisões judiciais. São Paulo: RT, 2001. v. 4, p. 288. No mesmo sentido, Rodrigo da Cunha Lima Freire denomina o juízo de admissibilidade realizado pelo relator de "juízo provisório” (Prequestionamento implícito em recurso especial: posição divergente no STJ. In: NERY JR., Nelson; WAMBIER, Teresa Arruda Alvim (Coord.). Aspectos polêmicos e atuais dos recursos cíveis e de outras formas de impugnação às decisões judiciais. São Paulo: RT, 2001. v. 4, p. 964).
} 
Processo Civil, “deferir em antecipação de tutela total ou parcialmente a pretensão recursal”.

Ainda, esta Lei acrescentou o $\S 3 .^{\circ}$ ao artigo 515, “nos casos de extinção do processo sem julgamento do mérito (art. 267), o tribunal pode julgar desde logo a lide, se a causa versar questão exclusivamente de direito e estiver em condições de julgamento”. Nesse caso, não se cogita de impedimento a que o relator proveja o recurso contra a sentença terminativa e desde logo passe ao exame do mérito da causa, inexistindo qualquer incompatibilidade com o artigo 557, § 1. ${ }^{\circ}$-A, uma vez que não há vantagem na decisão colegiada. Com isso ocorrerá verdadeira substituição de uma decisão monocrática por outra, sem qualquer inconveniente. ${ }^{463}$ Nesse caso, passou-se a admitir uma devolução ao tribunal daquilo que não foi objeto de julgamento pelo juiz de primeiro grau, podendo, então, o tribunal, julgar o mérito. ${ }^{464}$

A hipótese do $\S 3 .^{\circ}$ do artigo 515 não se trata de impugnação propriamente dita, porque o mérito não foi decidido em primeiro grau, o mérito será julgado pelo tribunal, à luz dos elementos constitutivos do contraditório já existente nos autos, nada impedindo que a parte arrazoe visando a um possível julgamento de mérito, aduzindo razões, traçando um quadro do contraditório existente no processo, postulando o bem do seu direito em relação ao mérito. Da mesma forma, o réu poderá discutir o mérito. ${ }^{465}$

Posteriormente, a Lei n. ${ }^{\circ}$ 11.187/2005 veio novamente ampliar os poderes do relator ao acrescentar o parágrafo único ao artigo 527 do Código de Processo Civil, passando o relator, autonomamente, à condição de juiz natural das decisões liminares em agravo de instrumento.

A análise sintética da redação do parágrafo único do artigo 527 demonstra que: a) a decisão do relator ao analisar a urgência da questão de fundo versada no recurso, para fins de avaliação sobre o cabimento do recurso de agravo de instrumento, passa a ser irrecorrível; b) também é irrecorrível a decisão do relator que deferir efeito suspensivo ao agravo de instrumento, ou conceder a antecipação da tutela recursal, excluída a hipótese de

${ }^{463}$ FRANCO, Fernão Borba. Vicissitudes do duplo grau de jurisdição: o art. 515, § 3. ${ }^{\circ}$, do CPC. In: MEDINA et al. (Coord.). Os poderes do juiz e o controle das decisões judiciais. Estudos em homenagem à Professora Teresa Arruda Alvim Wambier. São Paulo: RT, 2008. p. 704.

${ }^{464}$ Salienta José Manoel de Arruda Alvim que essa “devolução", a rigor, trata-se do efeito translativo (Notas sobre algumas das mutações verificadas com a Lei 10.352/2001. In: NERY JR., Nelson; WAMBIER, Teresa Arruda Alvim (Coord.). Aspectos polêmicos e atuais dos recursos cíveis e de outros meios de impugnação às decisões judiciais. São Paulo: RT, 2002. v. 6, p. 63).

${ }^{465}$ ARRUDA ALVIM, Eduardo, 2002. p. 78. 
interposição do agravo interno dirigido ao colegiado competente para a apreciação do mérito recursal. ${ }^{466}$

Cabe aqui uma análise quanto a reconhecer que há uma margem de liberdade de atuação do relator em virtude da indeterminação da lei no tocante ao modo concreto de satisfazê-la, visto que nos conceitos indeterminados a liberdade do aplicador do direito se exaure na fixação da premissa, da qual resulta a solução predeterminada. Portanto, a problemática em torno dos conceitos vagos ou indeterminados reside apenas no plano da interpretação. Inexistirá discricionariedade judicial, se o relator concluir pela presença do perigo de dano irreparável ou de difícil reparação e manter o regime de instrumento, no recurso de agravo. ${ }^{467}$

O teor do parágrafo único do artigo 527 - "somente é passível de reforma no momento do julgamento do agravo, salvo se o próprio relator a reconsiderar” - causa grande perplexidade, uma vez que é difícil imaginar que o órgão colegiado, ao julgar o agravo, reforme a decisão do relator que converteu o agravo em retido, pois fica sem sentido imaginar que se refere a restabelecer o instrumento. Destarte, a interpretação que se tem entendido é que dessa decisão (a da conversão do agravo de instrumento em retido) não cabe recurso para o colegiado, restando ao agravante o pedido de reconsideração, que não exclui, para o relator, a possibilidade de reconsiderar a sua decisão. ${ }^{468}$

Como já mencionado, pode o relator negar seguimento ao agravo liminarmente, nos casos do art. 557 do Código de Processo Civil, o que pode ser feito independentemente de se ter estabelecido o contraditório e mesmo sem ter o juiz prestado as informações, uma vez que o agravo, incidindo o art. 557, segue por um caminho diverso, diferente e incompatível com o artigo 527, III a VI. Logo, visto que o contraditório não está formado, na visão da processualista Teresa Arruda Alvim Wambier, não se aplica ao agravo o $\S 1$. $^{\circ}$

\footnotetext{
${ }^{466}$ NASCIMENTO, Bruno Dantas. Na contramão das reformas processuais: críticas ao novo parágrafo único do art. 527 do CPC, com redação dada pela Lei 11.187/2005. Revista de Processo. São Paulo, ano 30, n. 130, p. 96, dez. 2005.

${ }^{467}$ OLIVEIRA, Gleydson Kleber Lopes de. Hipóteses que não sujeitam à conversão do agravo de instrumento em retido. Exegese do art. 527, II do CPC, à luz da jurisprudência do STJ. In: MEDINA et al. (Coord.). Os poderes do juiz e o controle das decisões judiciais. Estudos em homenagem à Professora Teresa Arruda Alvim Wambier. São Paulo: RT, 2008. p. 722-723.

${ }^{468}$ Esse é o entendimento de BARBOSA MOREIRA (2010. item 134, p. 512-513). Quanto ao pedido de reconsideração, pondera João Batista Lopes que "excepcionalmente poderá o juiz reconsiderar suas decisões interlocutórias quando verificar a existência de manifesto lapso material. É que, nesses casos, por economia processual, não se vê razão para que o juiz deixe de corrigir erros evidentes, independentemente da interposição do agravo de instrumento, cujo procedimento burocratizado tem sido um entrave à celeridade processual". O autor ao final do artigo conclui que: "O pedido de reconsideração como substitutivo do agravo de instrumento, não tem forma, nem figura de juízo e, por isso, não pode ser admitido pelo juiz” (1984, p. 35 e 63).
} 
A do artigo 557, ou seja, o relator não pode, sob qualquer pretexto, dar provimento ao recurso sem estabelecer o contraditório, por mais evidentes que sejam as situações ocorrentes (aquelas listadas no $§ 10^{\circ}$-A). Salienta que essa solução decorre da própria letra do inciso I do artigo 527, que permite ao relator apenas negar seguimento ao agravo, nada estabelecendo a respeito da possibilidade de o relator dar-lhe provimento. ${ }^{469}$

Com isso, denota-se que os poderes do relator foram ampliados, com exclusão de poderes que pertenciam ao colegiado. Nessa nova sistemática, ao ser distribuído o agravo de instrumento, o relator analisará, preliminarmente, o seu cabimento, bem como analisará se a questão de mérito do recurso é ou não capaz de causar ao agravante lesão grave e de difícil reparação. Se o relator concluir de forma negativa, converterá o agravo em retido e determinará a sua remessa ao juízo de primeiro grau, mediante decisão liminar irrecorrível. ${ }^{470}$

A essencialidade dos poderes do relator no enfrentamento desses dois temas ganha ares de exclusividade quando se tem em conta a redação do parágrafo único do artigo 527 do Código de Processo Civil: “A decisão liminar, proferida nos casos dos incisos II e III do caput deste artigo, somente é passível de reforma no momento do julgamento do agravo, salvo se o relator a reconsiderar”. No entanto, essa exclusividade não é de fácil aferição. A brecha aberta para a reforma da decisão de retenção ou deliberação acerca da medida urgente já é o julgamento do recurso e a prerrogativa da reconsideração também é ato exclusivo do relator, que mantém com ele o poder de ditar os rumos do recurso. ${ }^{471}$

Ainda, a Lei n. ${ }^{\circ}$ 11.276/2006 acrescentou o § 4..$^{\circ}$ ao artigo 515 determinando que, na ocorrência de nulidade sanável, o tribunal poderá determinar a realização ou renovação do ato processual.

Diante da necessidade de agilizar a prestação jurisdicional quanto a certos incidentes e em vista da racionalidade e conveniência que se impõe na rotina dos tribunais, a prática de alguns atos é delegada ao relator, e, embora o $§ 4 .^{\circ}$ do artigo 515 mencione tribunal, é forçoso admitir que o relator pode, em decisão monocrática, determinar a

\footnotetext{
${ }^{469}$ WAMBIER, 2006. item 4.3.5, p. 297.

${ }^{470}$ Nesse sentido, Bruno Dantas Nascimento, o qual discorda quanto à irrecorribilidade estatuída pelo dispositivo: "Embora quatro dos potenciais efeitos nefastos do dispositivo em comento: insegurança jurídica, desprestígio dos juízes de primeiro grau e do colegiado, potencialização de erros judiciários e reavivamento do mandado de segurança para impugnar atos judiciais, estejam incluídos na margem de liberdade do legislador para tomada de decisões sobre política judiciária, situando-se no campo da (in)oportunidade e da (in)conveniência, dedicamos violações aos princípios constitucionais do acesso à justiça e do juiz natural, o que conduz o dispositivo à inconstitucionalidade material” (2005, p. 97).

${ }^{471}$ BONDIOLI, 2011.
} 
realização ou renovação do ato viciado, pois, quando o relator profere decisão isolada, funciona como porta-voz do tribunal. ${ }^{472}$

Importante mencionar novamente que o artigo 557 do Código de Processo Civil confere poderes ao relator e que razões de economia processual confirmam a possibilidade de aceitar a aplicação da regra do $\S 4{ }^{\circ}$ do artigo 515 por decisão singular. ${ }^{473}$

Após o crescente aumento dos poderes do relator, o que se verifica é que há duas vertentes jurisdicionais: a primeira relacionada com a possibilidade de concessão de medida de cunho interlocutório, resultante de situações urgentes em que se imponha decisão provisória; e a segunda, como decisões definitivas, com força de acórdão, seja pela possibilidade de rejeição liminar do recurso, ou na apreciação do mérito da matéria: ao se negar provimento em questão sumulada ou pacificada em Corte superior ou dando provimento em matéria já enfrentada pelo colegiado. ${ }^{474}$

A Lei n. ${ }^{0}$ 11.418/2006 acrescentou dois desdobramentos ao artigo 543 do Código de Processo Civil, dos quais o artigo 543-B prevê que, quando houver multiplicidade de recursos com fundamentação idêntica, a análise da repercussão geral será processada nos termos do Regimento Interno do Supremo Tribunal Federal, que, por sua vez, instituiu poderes especiais para o presidente e o relator, para barrar sumariamente o recurso extraordinário que chegue à Corte em situação que afronte o requisito da repercussão geral, quando a tese já tenha sido enfrentada pelo Plenário:

I - Ao presidente do STF cabe atuar como relator, enquanto o recurso não for distribuído, e nessa qualidade poderá, em decisão singular, inadmiti-lo, liminarmente em duas circunstâncias: (RISTF, arts. 13, V, e 327, caput.)

a) Quando das razões recursais não constar a "preliminar formal e fundamentada da "repercussão geral” como exige o art. 543-A, § 2. ${ }^{\circ}$, do CPC;

b) Quando a matéria arguida na preliminar "seja destituída de repercussão geral”, conforme jurisprudência do STF.

II - Efetuada a distribuição, sem que o presidente tenha liminarmente inadmitido o recurso, caberá ao relator sorteado, em decisão singular:

\footnotetext{
${ }^{472}$ CARNEIRO DA CUNHA, Leonardo José. Sanação de defeitos processuais no âmbito recursal. In: MEDINA et al. (Coord.). Os poderes do juiz e o controle das decisões judiciais. Estudos em homenagem à Professora Teresa Arruda Alvim Wambier. São Paulo: RT, 2008. p. 765-766.

${ }^{473}$ BEDAQUE, 2006, p. 232. Em sentido diverso posiciona-se William Santos Ferreira: "precedentes do STF ilustram que a Constituição Federal, ao empregar a terminologia 'tribunal', expressa órgão julgador colegiado, o que significa que a decisão monocrática nos tribunais somente não é constitucional se for assegurado à parte atingida dela decisão recurso que leve a questão à apreciação do órgão competente, do 'juízo natural', que é o órgão colegiado, a quem caberá manter ou alterar a decisão” (Decisões do relator e a recorribilidade assegurada pelo parágrafo único do art. 527 do CPC - uma questão de perspectiva. In: MEDINA et al. (Coord.). Os poderes do juiz e o controle das decisões judiciais. Estudos em homenagem à Professora Teresa Arruda Alvim Wambier. São Paulo: RT, 2008. p. 871).

${ }^{474}$ CAVALCANTE, 2008. p. 796.
} 
a) Negar seguimento ao recurso quando manifestamente inadmissível, improcedente ou contrário à jurisprudência dominante ou a súmula do STF, nos termos do art. 557 do CPC, e artigo 21, § 1. ${ }^{\circ}$, do RISTF;

b) Inadmiti-lo por falta da preliminar de repercussão geral formal e fundamentada nas razões recursais (RISTF, art. 327, § 1. ${ }^{\circ}$ );

c) Inadmiti-lo, ainda, por falta de repercussão geral, caso a questão suscitada em preliminar já tenha sido rejeitada em precedente do STCF (RISTF, art. 327, § $\left.1 .^{\circ}\right)$

d) Julgar o recurso para cassar ou reformar, liminarmente, o acórdão recorrido quando "contrário à orientação firmada nos termos do art. 543-B do Código de Processo Civil”.

Trata-se da situação em que o STF já teria, em precedente, reconhecido a repercussão geral da questão e já decidido sobre o seu mérito. Se mesmo assim o tribunal a quo insistiu em manter o entendimento diverso, ao relato do STF, caberá, liminarmente, cassar ou reformar o acórdão recorrido, para fazer prevalecer a tese já assentada no caso paradigma. ${ }^{475}$

A Lei n. ${ }^{\circ}$ 11.672/2008 instituiu um terceiro desdobramento ao artigo 543, estabelecendo o artigo 543-C que, quando houver multiplicidade de recursos com fundamento em idêntica questão de direito, o recurso especial será processado nos termos de seus parágrafos. ${ }^{476}$

Essa sucinta memória de fatos da história, relativamente recente do direito processual brasileiro, demonstra que o crescimento dos poderes do relator caminha pari

\footnotetext{
475 THEODORO JÚNIOR, Humberto. O poder de controle do cabimento do recurso extraordinário referente ao requisito da repercussão geral (CF, art. 102, § 3. ${ }^{\circ}$ ). In: MEDINA et al. (Coord.). Os poderes do juiz e o controle das decisões judiciais. Estudos em homenagem à Professora Teresa Arruda Alvim Wambier. São Paulo: RT, 2008. p. 937.

${ }^{476}$ Art. 543-C. Quando houver multiplicidade de recursos com fundamento em idêntica questão de direito, o recurso especial será processado nos termos deste artigo. § $1 .^{\circ}$ Caberá ao presidente do tribunal de origem admitir um ou mais recursos representativos da controvérsia, os quais serão encaminhados ao Superior Tribunal de Justiça, ficando suspensos os demais recursos especiais até o pronunciamento definitivo do Superior Tribunal de Justiça. § $2 .^{\circ}$ Não adotada a providência descrita no $\S 1 .^{\circ}$ deste artigo, o relator no Superior Tribunal de Justiça, ao identificar que sobre a controvérsia já existe jurisprudência dominante ou que a matéria já está afeta ao colegiado, poderá determinar a suspensão, nos tribunais de segunda instância, dos recursos nos quais a controvérsia esteja estabelecida. $§ 3 .^{\circ}$ O relator poderá solicitar informações, a serem prestadas no prazo de quinze dias, aos tribunais federais ou estaduais a respeito da controvérsia. $\S 4 .^{\circ} \mathrm{O}$ relator, conforme dispuser o regimento interno do Superior Tribunal de Justiça e considerando a relevância da matéria, poderá admitir manifestação de pessoas, órgãos ou entidades com interesse na controvérsia. § $5 .{ }^{\circ}$ Recebidas as informações e, se for o caso, após cumprido o disposto no $\S 4 .^{\circ}$ deste artigo, terá vista o Ministério Público pelo prazo de quinze dias. $\S 6 .^{\circ}$ Transcorrido o prazo para o Ministério Público e remetida cópia do relatório aos demais Ministros, o processo será incluído em pauta na seção ou na Corte Especial, devendo ser julgado com preferência sobre os demais feitos, ressalvados os que envolvam réu preso e os pedidos de habeas corpus. § 7. ${ }^{\circ}$ Publicado o acórdão do Superior Tribunal de Justiça, os recursos especiais sobrestados na origem: I - terão seguimento denegado na hipótese de o acórdão recorrido coincidir com a orientação do Superior Tribunal de Justiça; ou II - serão novamente examinados pelo tribunal de origem na hipótese de o acórdão recorrido divergir da orientação do Superior Tribunal de Justiça. § 8..$^{\circ}$ Na hipótese prevista no inciso II do $\S 7 .^{\circ}$ deste artigo, mantida a decisão divergente pelo tribunal de origem, far-se-á o exame de admissibilidade do recurso especial. § $9 .^{\circ}$ O Superior Tribunal de Justiça e os tribunais de segunda instância regulamentarão, no âmbito de suas competências, os procedimentos relativos ao processamento e julgamento do recurso especial nos casos previstos neste artigo.
} 
passu com o incremento e valorização dos precedentes jurisprudenciais. A esse respeito, discorre Cândido Rangel Dinamarco que as súmulas são como patamar intermediário entre a lei e o abstrato, e a lei e o concreto das decisões judiciárias em casos específicos. Não se pode afirmar que a jurisprudência é fonte formal do direito, mas há uma aproximação, em razão da crescente força dos precedentes, principalmente, quando se insere no direito constitucional o seu efeito vinculante. “O valor das súmulas não se confina ao quadro dos poderes do relator, não obstante o caminhar paralelo dos dois fenômenos. Também os órgãos colegiados dos tribunais são autorizados a valer-se delas, dispensando-se a alusão a outros precedentes (RISTF, art. 102, § 4. ${ }^{\circ}$ ).”477

O que se espera do relator é o exame cuidadoso da matéria recursal, não tornando a decisão, por exemplo, de conversão do agravo de instrumento em agravo retido num despacho automatizado, mas sim num despacho fundamentado do seu posicionamento num sentido ou noutro. ${ }^{478}$

Cândido Rangel Dinamarco salienta que a tendência crescente da singularidade no julgamento, em diversas situações, traduz a legítima tentativa de inovação sistemática na luta contra a lentidão dos julgamentos nos tribunais, uma vez que o aumento de juízes não resolve o problema, sendo necessária a renovação do sistema.

Representa uma escalada que vem da colegialidade quase absoluta e aponta para a singularização dos julgamentos nos tribunais, restrita a casos onde se prevê que os órgãos colegiados julgariam segundo critérios objetivos e temperada pela admissibilidade de agravo dirigido a eles. ${ }^{479}$

\subsection{Competência funcional do relator}

A competência para o julgamento dos recursos, em regra, é atribuída aos tribunais por meio dos seus órgãos colegiados, turmas e câmaras e aos órgãos individualizados,

\footnotetext{
${ }^{477}$ DINAMARCO, 1999. p. 130.

478 LOPES, Renan Kfuri. Lei n. ${ }^{0}$ 11.187, de 19.10.2005 - Regime de retenção recursal - agravo de instrumento e agravo retido. Revista Jurídica. Sapucaia do Sul, ano 55, n. 352, p. 131, fev. 2007.

${ }^{479}$ DINAMARCO, 1999. p. 130. O oposto ocorreu no direito italiano, como aponta Giuseppe Tarzia: "La scelta di fondo (come si è detto) è stata quella per la integrale, rigorosa collegialità del processo d'appello in ogni sua fase, com la conseguente soppressione della figura dell'istruttore. Il processo giunge dunque dinanzi al collegio già din dalla prima udienza e 'la trattazione dell'appello è collegiale' (art. $350,1 .^{\circ}$ comma C.P.C.)” (1996. p. 249).
} 
como presidente, vice-presidente, corregedor, relator e revisor. A competência desses órgãos é funcional, também denominada hierárquica ou recursal. ${ }^{480}$

Doutrinadores como Nelson Nery Junior e Eduardo Talamini entendem que, para as hipóteses dos artigos 544 e 557 do Código de Processo Civil, a decisão do relator é preliminar, porque está sujeita ao controle do órgão colegiado competente para julgar o recurso, "o relator atua, portanto, com função diferida do órgão colegiado a que pertence”. ${ }^{481}$

Para José Carlos Barbosa Moreira, o papel do relator pode se equiparar a um portavoz avançado, supondo-se o direito de desencadear um mecanismo de controle capaz de demonstrar se a antecipação correspondeu ou não ao entendimento antecipado. ${ }^{482}$

José Rogério Cruz e Tucci, ao comentar o parágrafo único do artigo 557, afirma que a atividade decisória preambular do juiz relator é delegada pelo colegiado, órgão jurisdicional natural no sistema do duplo grau, e encontra-se em perfeita harmonia com o direito brasileiro que sempre concebeu, para o reexame das decisões de primeiro grau, julgamento por órgão colegiado. ${ }^{483}$

Há aqueles que criticam esse posicionamento em razão da competência funcional que o relator exerce, além de argumentarem que a atividade cognitiva do relator, desenvolvida com base nos artigos 544 e 557 do Código de Processo Civil, não pode ser considerada como preliminar de outro órgão, além de não se dever apoiar a afirmação de que a atividade decisória do relator está sujeita à fiscalização do órgão coletivo. A funcionalidade do relator provém da lei, e não do órgão colegiado, como também não se trata de competência passageira. ${ }^{484}$

\footnotetext{
${ }^{480}$ CARVALHO, Fabiano. Poderes do relator nos recursos art. 557 do CPC. São Paulo: Saraiva, 2008. p. 49.

${ }^{481}$ NERY JR., 2014. item 3.4, p. 264. No mesmo sentido, Eduardo Talamini: "Essa é a forma de verificar se o relator correspondeu, na prática do ato que lhe foi delegado, ao pretendido pelo órgão colegiado" (Decisões individuais: legitimidade e controle. In: NERY JR., Nelson; WAMBIER, Teresa Arruda Alvim (Coord.). Aspectos polêmicos e atuais dos recursos cíveis. v. 5, 2002. p. 181).

${ }^{482}$ BARBOSA MOREIRA, José Carlos. Inovações da Lei 9.756 em matéria de recursos cíveis. In: NERY JR., Nelson; WAMBIER, Teresa Arruda Alvim (Coord.). Aspectos polêmicos e atuais dos recursos cíveis de acordo com a Lei 9.756/98. São Paulo: RT, 1999. p. 324.

${ }^{483}$ CRUZ E TUCCI José Rogério. Sobre a atividade decisória do relator do agravo de instrumento. Revista do Advogado. São Paulo: AASP, n. 48, p. 57, jul. 1996.

${ }^{484}$ Fabiano Carvalho afirma que, em linha de princípio, “quando interposto agravo interno (arts. 545 e 557, § $1 .^{\circ}$, do CPC). Mas pode suceder que esse recurso não seja interposto, de maneira que não será dada a conhecimento do órgão colegiado a decisão individual do relator, a qual será provida de auctoritas rei iudicatae ou preclusão" (2008. p. 51 e 53).
} 
Já Athos Gusmão Carneiro entende que o relator, nesses casos, não estará decidindo por delegação do colegiado a que pertence, uma vez que exerce poder jurisdicional que lhe foi outorgado por lei. Sustenta que, por razões de política judiciária, assecuratória da colegialidade das decisões em sede recursal, a lei processual prevê o direito de a parte reiterar o apelo ao colegiado para afastar qualquer eiva de inconstitucionalidade da referida norma legal. ${ }^{485}$

O legislador pátrio gradualmente foi ampliando os poderes do relator, permitindolhe que não somente profira decisão monocrática sobre a admissibilidade dos recursos, como, também, disponha a respeito do seu mérito. Em consequência, há um confronto com posição tradicional que, salvo raras exceções, sempre teve o exame dos recursos, em especial, o que diz respeito ao mérito efetuado por órgãos colegiados. ${ }^{486}$

Vicente Greco Filho, ao comentar a Lei n. ${ }^{\circ}$ 9.756/1998, assevera que a intenção do legislador foi facilitar o julgamento dos recursos, mediante a estratégia de atribuir maiores poderes ao relator. $^{487}$

O Código de Processo Civil e os regimentos internos dos tribunais estabelecem a competência dos órgãos colegiados no campo dos recursos. No julgamento da apelação ou do agravo, a decisão será tomada pelo voto de três juízes, conforme dispõe o artigo 555 do

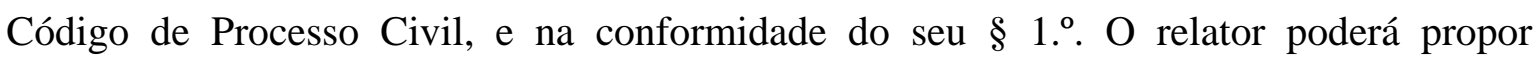
julgamento ao recurso pelo órgão colegiado indicado pelo regimento. Os embargos infringentes e os embargos divergentes serão julgados, colegiadamente, conforme dispuser o regimento interno do tribunal (artigos 533 e 546, parágrafo único, do Código de Processo Civil). O agravo interno é julgado pelo órgão colegiado competente para o recurso principal (artigo 557, § 1. ${ }^{\circ}$, do Código de Processo Civil.). Os órgãos individualizados também têm competência: os recursos extraordinário e especial são interpostos perante o presidente ou vice-presidente do tribunal recorrido, que fará o juízo de admissibilidade conforme artigos 541 e 542, § 1. ${ }^{\circ}$, ambos do Código de Processo Civil. O relator tem competência funcional para a prática de determinados atos de procedimento recursal, tais como: requisitar informações ao juiz da causa para os casos de interposição de agravo de instrumento (artigo 527, IV, do Código de Processo Civil). A competência funcional do

\footnotetext{
${ }^{485}$ CARNEIRO, 2000, p. 9.

${ }^{486}$ PUOLI, 2002. p. 193-194.

${ }^{487}$ GRECO FILHO, Vicente. Questões sobre a Lei 9.756, de 17 de dezembro de 1998. In: NERY JR., Nelson; WAMBIER, Teresa Arruda Alvim (Coord.). Aspectos polêmicos e atuais dos recursos cíveis de acordo com a Lei 9.756/98. São Paulo: RT, 1999. p. 599.
} 
relator se estende para apreciar matérias relacionadas aos requisitos de admissibilidade dos recursos, como também julgar seu mérito (artigos 544 e 557, ambos do Código de Processo Civil), podendo prolatar nova decisão que substituirá a sentença ou a decisão recorrida no que tiver sido objeto do recurso (art. 512 do Código de Processo Civil). ${ }^{488}$

O relator julgará sem a participação do colegiado, no caso de o recurso ser manifestamente inadmissível, improcedente, prejudicado ou contrário à súmula ou jurisprudência dominante do tribunal competente para o julgamento do recurso, do Supremo Tribunal Federal ou Superior Tribunal de Justiça, se a decisão recorrida estiver em contraste com a orientação (súmula ou jurisprudência) desses tribunais.

\subsection{Natureza jurídica da decisão monocrática do relator}

O teor do artigo 557 do Código de Processo Civil resume o procedimento recursal, dando celeridade no julgamento, de maneira a prestar a tutela jurisdicional num tempo razoável.

A lei agrupou hipóteses para julgamento do recurso por meio de decisão monocrática do relator, não somente na inadmissibilidade do recurso, mas também no julgamento de mérito, quando manifestamente improcedente ou procedente; quando prejudicado, contrário à súmula, ou desfavorável à jurisprudência dominante do tribunal competente para o julgamento do recurso.

O pronunciamento individual da atividade decisória do relator poderá assumir a natureza de: a) decisão interlocutória, quando o pronunciamento resolve questão incidente; ou b) acórdão, quando a decisão resolve ou não o mérito da causa (artigos 267 e 269 do Código de Processo Civil), podendo determinar a extinção do processo (artigo 267 do Código de Processo Civil).

O relator passou legalmente (e não apenas regimentalmente) a poder examinar o próprio mérito do recurso, com o poder de negar seguimento ou negar provimento a recurso manifestamente improcedente, ou seja, quando o fundamento do recurso for contrário: a) à matéria, de fato, decorrente da prova dos autos; b) em matéria de direito, já consagrada pelos tribunais. Ao relator cabe negar seguimento ao recurso, quando a tese

${ }^{488}$ CARVALHO, 2008. p. 49-58. 
jurídica em que se baseou a inconformidade viesse a contrariar súmula do tribunal de destino ou de tribunal superior (STF e STJ), a respeito da questão fundamental à solução da lide. Também cabe ao relator negar seguimento a recurso prejudicado, por exemplo, no caso de agravo de instrumento em que foi, no interregno, reconsiderada a decisão agravada, ou em cujo processo foi proferida a sentença transitada em julgado. Quanto ao recurso manifestamente improcedente, o relator não somente deixa de encaminhar o recurso ao órgão colegiado, ao qual em princípio era dirigido, mas declara que não procede a própria pretensão recursal, decidindo monocraticamente com a mesma eficácia e amplitude de que se revestiria a decisão colegiada. Ainda, a imperatividade contida na expressão "negará seguimento" apresenta-se relativa, mesmo quando parece duvidoso ao relator o acerto do provimento recorrido, tanto no exame dos fatos como no das questões. Em determinados casos, será conveniente, pela relevância do tema no aspecto jurídico ou em suas repercussões sociais, que sobre a lide se pronuncie o colegiado. ${ }^{489}$

\subsection{Poder/dever do relator}

Em todos os dispositivos que ampliam os poderes do relator, o verbo empregado é “poder”, e não “dever”, o que significa que o legislador quis deixar, ao prudente arbítrio do próprio relator, a opção de julgar por si próprio monocraticamente ou encaminhar ao colegiado. Essa opção “dependerá sempre do grau de conviç̧ão do relator, a quem competirá, com honestidade profissional, abster-se de julgar quando sentir que a matéria não é tão segura que legitime esses verdadeiros atalhos procedimentais instituídos pela lei”. 490

A imperatividade da expressão "negará seguimento” não obriga o relator a indeferir o recurso interposto, contrariando, por exemplo, súmula do próprio tribunal ou de tribunal superior, uma vez que se trata de faculdade que a lei confere ao relator. ${ }^{491}$

Cândido Rangel Dinamarco salienta que essa redação que insinua obrigatoriedade é oriunda da reforma processual de 1995, e a nova lei se limitou a reproduzi-la. No entanto, o emprego do advérbio “manifestamente” acaba por criar na prática a mesma situação,

\footnotetext{
${ }^{489}$ CARNEIRO, 2000, p. 9.

${ }^{490}$ DINAMARCO, 1999. p. 130.

${ }^{491}$ CARVALHO, 2008. p. 62.
} 
porque será dever do relator abster-se de julgar de plano, sempre que não vir uma situação manifesta, isto é, límpida e indiscutível. ${ }^{492}$

No entendimento de José Carlos Barbosa Moreira, o termo "manifestamente" constante no caput do artigo 557 assume sentido restritivo, se ao relator pareceu enquadrarse o recurso numa das classes arroladas, ou seja, se para ele a inadmissibilidade ou improcedência do recurso se fez manifesta, compete-lhe negar seguimento ao recurso. Esse advérbio "manifestamente” vale como recomendação aos relatores para que exercitem com comedimento essa atribuição, uma vez que a imperatividade colhida na forma verbal “negará” não há como entender obrigatório o exercício do poder atribuído ao relator. ${ }^{493}$

A função decisória do relator, para julgar antecipadamente o recurso, decorre das hipóteses previstas no artigo 557 do Código de Processo Civil. O julgamento monocrático somente será realizado quando o relator estiver convencido de suas razões e seguro de que o recurso se amolda a uma das categorias expressas na lei. Ocorrendo qualquer dúvida, o relator deverá se abster de julgar monocraticamente, direcionando o recurso ao julgamento colegiado. Nesse sentido, pode-se afirmar que a atuação decisória do relator, para julgamento de recurso sem a participação do órgão coletivo, está limitada na lei. ${ }^{494}$

O momento adequado para o relator proferir o julgamento antecipado é o seguinte à conclusão dos autos, depois de ouvir o recorrido para o exame do recurso. Assim, não deve o relator, ao menos em princípio, postergar a negativa do seguimento. ${ }^{495}$

\subsection{Motivação da decisão unipessoal}

A decisão do relator que nega seguimento ao recurso tem de ser fundamentada por imposição constitucional (art. 93, IX). Além disso, para suprir a exigência de fundamentação, é necessário ao relator explicitar as razões pelas quais se fundam o seu convencimento. Portanto, afirma-se que tal jurisprudência é dominante, há de documentar

\footnotetext{
492 DINAMARCO, 1999. p. 132.

493 BARBOSA MOREIRA, 2010, p. 683-684.

${ }^{494}$ CARVALHO, 2008. p. 71.

495 BARBOSA MOREIRA, 2010, p. 686.
} 
o asserto. É necessário que a fundamentação contenha tudo aquilo que teria de figurar na motivação do acórdão do colegiado, se porventura o recurso chegasse até ele. ${ }^{496}$

Segundo Fabiano Carvalho, não é lícito ao relator decidir sem fundamentar, ou seja, sem transmitir às partes os motivos que o levaram a proferir a sua decisão monocrática sem a participação do colegiado, seja ela para negar seguimento (artigo 557, caput, do Código de Processo Civil), ou para dar provimento a recurso (artigo 557, § 1. ${ }^{\circ}$-A, do Código de Processo Civil). A exigência se justifica uma vez que a parte tem a opção de interpor agravo, individualizando o objeto impugnado, de modo que o órgão judicial colegiado, competente para o julgamento, estará apto a realizar uma análise lógico-jurídica, verificando se a decisão do relator foi ou não correta no aspecto jurídico. ${ }^{497}$

Se o relator nega seguimento ao recurso por manifestada inadmissibilidade ou improcedência, deve expor, com clareza, os fundamentos e as razões de seu convencimento; se mencionar jurisprudência dominante, terá que documentar o que alega.

${ }^{496}$ BARBOSA MOREIRA, 2010, p. 686-687.

${ }^{497}$ CARVALHO, 2008. p. 79. 


\section{O NOVO CPC E A BUSCA DO EQUILÍbRIO QUANTO À FORMA NO EXAME DE ADMISSIBILIDADE DOS RECURSOS}

O projeto do novo Código de Processo Civil (PL n. ${ }^{\circ}$ 8.046/2010), aprovado pela Câmara dos Deputados em 26.03.2014, ${ }^{498}$ tem o objetivo de modernizar o processo civil e adaptá-lo às exigências do direito material, e, segundo o entendimento de José Manuel de Arruda Alvim, “observa-se uma dedicação especial à chamada jurisprudência defensiva nos Tribunais Superiores, traduzida pelo extremo rigor na admissibilidade dos recursos”. 499

O número de recursos excepcionais continua elevado, assim como a jurisprudência defensiva persiste como obstáculo nos tribunais superiores, o que se verifica em inúmeros julgados. Proliferaram orientações formalistas na admissibilidade desses recursos conforme já demonstrado neste estudo, criando-se uma jurisprudência defensiva com base em fundamentos puramente pragmáticos consubstanciados no excessivo número de recursos protocolados anualmente nos tribunais de cúpula. ${ }^{500}$

O projeto do novo Código de Processo Civil, com o intuito de resolver esse quadro de efetiva litigiosidade, aposta no fortalecimento da jurisprudência dos tribunais, bem como de institutos, como o incidente de resolução de demandas repetitivas, que amplia a técnica de julgamento por amostragem, a ser suscitado perante o Tribunal de Justiça ou Tribunal Federal, o que está previsto no artigo 988, § $1^{0.501}$

Os recursos especial e extraordinário, de competência do Superior Tribunal de Justiça e do Supremo Tribunal Federal, são recursos excepcionais destinados a conferir a correta interpretação à lei federal e à Constituição.

As exigências relativas à admissão desses recursos excepcionais são muitas vezes justificáveis. No entanto, a formalidade excessiva obsta o acesso à Justiça. Verifica-se que o projeto do novo Código de Processo Civil prevê a possibilidade de o tribunal

\footnotetext{
${ }^{498}$ Em dezembro de 2014 o projeto encontra-se em pauta de votação no plenário do Senado Federal.

${ }^{499}$ ARRUDA ALVIM, José Manuel. STF rumo à flexibilização da jurisprudência defensiva. Disponível em: <http://www.oab.org.br/util/print/24648?print=Noticia>. Acesso em: 26 fev. 2014.

${ }^{500}$ DELLORE, Luiz; GAJARDONI, Fernando da Fonseca; OLIVEIRA JUNIOR, Zulmar Duarte de; ROQUE, André Vasconcelos. A jurisprudência defensiva ainda pulsa no novo CPC. Disponível em: $<$ http://www.conjur.com.br/2013-set-06/jurisprudencia-defensiva-ainda-pulsa-codigo-processo-civil?>. Acesso em: 21 dez. 2013.

${ }^{501}$ Cf. Projeto do novo Código de Processo Civil (PL n. ${ }^{\circ}$ 8.046/2010), aprovado pela Câmara dos Deputados em 26.03.2014, que em dezembro de 2014 encontra-se em pauta de votação no plenário do Senado Federal.
} 
desconsiderar vício formal na interposição dos recursos ou de determinar-lhe a correção, desde que não o repute grave. ${ }^{502}$

O caput do artigo 1.042 prevê que os recursos extraordinário e especial serão interpostos perante o presidente ou vice-presidente do tribunal recorrido, em petições distintas. Prescreve o artigo:

Art. 1.042 “O recurso extraordinário e o recurso especial, nos casos previstos na Constituição Federal, serão interpostos perante o presidente ou o vice-presidente do tribunal recorrido, em petições distintas que conterão:

I - a exposição do fato e do direito;

II - a demonstração do cabimento do recurso interposto;

III - as razões do pedido de reforma ou de invalidação da decisão recorrida.

O $\S 1$. $^{\circ}$ do artigo 1.042 facilita ao recorrente o modo de fazer a comprovação da divergência em dissídio jurisprudencial, que poderá ser mediante “certidão, cópia ou citação do repositório de jurisprudência, oficial ou credenciado, inclusive em mídia eletrônica, em que tiver sido publicada a decisão divergente, ou ainda pela reprodução de julgado disponível na rede mundial de computadores, com indicação da respectiva fonte”

Prescreve:

$\S 1 .^{\circ}$ Quando o recurso fundar-se em dissídio jurisprudencial, o recorrente fará a prova da divergência com a certidão, cópia ou citação do repositório de jurisprudência, oficial ou credenciado, inclusive em mídia eletrônica, em que houver sido publicado o acórdão divergente, ou ainda com a reprodução de julgado disponível na rede mundial de computadores, com indicação da respectiva fonte, em qualquer caso, as circunstâncias que identifiquem ou assemelhem os casos confrontados devem ser mencionados.

Esse dispositivo flexibiliza a prova da divergência jurisprudencial, ao aceitar a reprodução de julgado disponível na mídia eletrônica, desde que seja apresentada a respectiva fonte, o que facilitará ao tribunal, a constatação da veracidade da informação.

O § 2. ${ }^{\circ}$ do artigo 1.042 veda ao órgão jurisdicional, aqui representado pelo relator, a inadmissibilidade do recurso que estiver fundado em dissídio jurisprudencial com base em fundamento genérico de que as circunstâncias fáticas são diferentes sem demonstrar a existência da distinção.

Prescreve:

$\S 2 .^{\circ}$ Quando o recurso estiver fundado em dissídio jurisprudencial, é vedado ao órgão jurisdicional inadmiti-lo com base em fundamento genérico de que as circunstâncias fáticas são diferentes, sem demonstrar a existência da distinção.

${ }^{502}$ ARRUDA ALVIM, 2014. 
O $\S 3 .^{\circ}$ do artigo 1.042 flexibiliza a manutenção e julgamento de recurso tempestivo, cujo vício formal não seja grave, quando dispõe:

$\S 3 .^{\circ}$ O Supremo Tribunal Federal ou o Superior Tribunal de Justiça poderá desconsiderar vício formal de recurso tempestivo ou determinar sua correção, desde que não o repute grave.

O disposto nesse parágrafo corrobora com o que defendemos nesta dissertação quanto a flexibilizar a análise dos requisitos intrínsecos e extrínsecos quando as razões recursais possuírem vícios que possam ser sanados pelo recorrente ou sejam irrelevantes para o andamento processual, pois o acesso à justiça é direito constitucional assegurado à parte que interpôs o recurso, em razão do direito material em discussão no processo.

Os vícios formais passíveis de serem corrigidos não podem prevalecer em relação ao direito invocado por quem espera por justiça e a requer na fase recursal, visto que as exigências de preenchimento dos requisitos formais dos recursos pertencem ao direito processual que é instrumento do direito material.

O direito material, ou seja, o bem da vida levado à discussão no Judiciário por meio da propositura da ação, deve sempre prevalecer, em relação ao direito processual, que é a atividade pela qual se exerce a função jurisdicional e que é simplesmente um meio de alcançar o escopo final de toda a controvérsia levada a juízo, ou seja, o direito processual é o instrumento de composição das lides.

A oportunidade de correção do vício nessa fase recursal fará com que mais recursos sejam conhecidos e tenham o seu mérito analisado, proporcionando às partes a oportunidade de terem uma decisão que analise a questão do direito material que gerou a controvérsia levada a juízo.

Outra questão é que a inadmissibilidade de um recurso que contenha vício sanável, realizada pelo relator no juízo de admissibilidade, gera uma insatisfação por parte daquele que recorreu, levando-o a recorrer (agravar) daquela decisão monocrática, o que contribui para o aumento da quantidade de recursos protocolados nos tribunais, ou seja, em vez da análise de um único recurso, o tribunal terá que examinar dois, a correção do vício poderá eliminar a possibilidade da propositura desse novo recurso, o que contribuirá com diminuição do número recursos protocolados. 
Outro viés que se analisa é que a possibilidade de correção de vício formal que não se repute grave corrobora com o direito fundamental de acesso à justiça, previsto na Constituição Federal (artigo 5. ${ }^{\circ}$, incisos XXXV e LXXVIII), proporcionando ao recorrente uma tutela jurisdicional efetiva com a análise do mérito.

O $\S 4 .^{\circ}$ do mesmo artigo 1.042 prevê que quando se tratar de resolução de demandas repetitivas, por razões de segurança ou de excepcional interesse social, havendo pedido de suspensão de processos, a eficácia da medida se estenderá a todo o território nacional, até decisão final do recurso interposto (extraordinário ou especial).

§ 4. ${ }^{\circ}$ Quando, por ocasião de incidente de resolução de demandas repetitivas, o presidente do Supremo Tribunal Federal ou do Superior Tribunal de Justiça receber requerimento de suspensão de processos em que se discuta questão federal constitucional ou infraconstitucional, poderá, considerando razões de segurança jurídica ou de excepcional interesse social, estender a eficácia da medida a todo o território nacional, até ulterior decisão do recurso extraordinário ou do recurso especial interposto.

Além desse dispositivo, o projeto do novo Código de Processo Civil ${ }^{503}$ demonstra a preocupação do legislador na busca em debelar a jurisprudência defensiva em nosso ordenamento jurídico, o que se denota pelos seguintes dispositivos:

a) Art. 76, § 2. ${ }^{\circ}$ - Evidencia que a regra do art. 13 do atual Código de Processo Civil também se aplica à instância recursal. Assim, em caso de incapacidade processual ou irregularidade de representação da parte, deverá o relator possibilitar a correção do vício em prazo razoável, antes que não conheça do recurso ou determine o desentranhamento das contrarrazões. Com isso busca-se afastar o entendimento consolidado na Súmula n. ${ }^{\circ} 115$ do Superior Tribunal de Justiça: “Na instância especial é inexistente recurso interposto por advogado sem procuração nos autos”.

Art. 76. Verificada a incapacidade processual ou a irregularidade da representação da parte, o órgão jurisdicional suspenderá o processo e designará prazo razoável para que seja sanado o vício.

[...]

$\S 2 .^{\circ}$ Descumprida a determinação, caso o processo esteja em grau de recurso perante tribunal de justiça, tribunal regional federal ou tribunal superior, o relator:

I - não conhecerá do recurso, se a providência couber ao recorrente;

${ }^{503}$ PL n. ${ }^{\circ}$ 8.046/2010 aprovado pela Câmara dos Deputados em 26.03.2014, em tramitação para votação no plenário do Senado Federal. 
II - determinará o desentranhamento das contrarrazões, se a providência couber ao recorrido.

b) Art. 218, $\S 4 .^{\circ}$ - Estabelece a tempestividade do ato praticado (interposição de recurso, por exemplo) antes do termo inicial do prazo, o que derruba a jurisprudência relativa a "intempestividade por prematuridade".

Art. 218. Os atos processuais serão realizados nos prazos prescritos em lei.

$[\ldots]$

$\S 4 .^{\circ}$ Será considerado tempestivo o ato praticado antes do termo inicial do prazo.

c) Art. 945, parágrafo único - Estabelece a possibilidade de correção de vício ou complementar a documentação no âmbito recursal.

Art. 945. Incumbe ao relator:

[...]

Parágrafo único. Antes de considerar inadmissível o recurso, o relator concederá o prazo de cinco dias ao recorrente para que seja sanado vício ou complementada a documentação exigível.

d) Art. 1.016, $\S 5^{\circ}$ - Este parágrafo iguala o prazo para a propositura de todos os recursos, que será de 15 dias, com exceção dos embargos de declaração. O teor do $\S$ 5. ${ }^{\circ}$ acabará com a questão do prazo na aplicação do princípio da fungibilidade entre o recurso de apelação e agravo de instrumento.

Art. 1.016. O prazo para interposição de recurso conta-se da data em que os advogados, a sociedade de advogados, a Advocacia Pública, a Defensoria Pública ou o Ministério Público são intimados da decisão.

$\S 5 .^{\circ}$ Excetuados os embargos de declaração, o prazo para interpor os recursos e para responder-lhes é de quinze dias.

e) Art. 1.020 - Determina que o preparo continue a ser prévio sob pena de deserção.

Art. 1.020. No ato de interposição do recurso, o recorrente comprovará, quando exigido pela legislação pertinente, o respectivo preparo, inclusive porte de remessa e de retorno, sob pena de deserção. 
§ 2. ${ }^{\circ}$ - O equívoco no preenchimento da guia de custas não resultará na aplicação da pena de deserção, incumbindo ao relator, em caso de dúvida quanto ao recolhimento, intimar o recorrente para sanar o vício em cinco dias. Corresponde à mitigação do formalismo nas guias de preparo.

$\S 2 .^{\circ}$ A insuficiência no valor do preparo ou do porte de remessa e retorno implicará deserção, se o recorrente, intimado na pessoa de seu advogado, não vier a supri-lo no prazo de cinco dias.

§§ 4. ${ }^{\circ}$ e 5. ${ }^{\mathbf{o}}$ - O legislador mais uma vez flexibiliza ao permitir o preparo em dobro, caso não o tenha comprovado na interposição do recurso, porém veda a complementação se houver insuficiência parcial nesse recolhimento em dobro.

$\S 4 .^{\circ} \mathrm{O}$ recorrente que não comprovar o recolhimento do preparo e do porte de remessa e retorno no ato de interposição do recurso será intimado, na pessoa de seu advogado, para realizar o recolhimento em dobro, sob pena de deserção.

§ 5..$^{\circ}$ É vedada a complementação se houver insuficiência parcial do preparo ou do porte de remessa e retorno no recolhimento realizado na forma do parágrafo $4 .^{\circ}$.

§ 6. ${ }^{\circ}$ - Novamente uma flexibilização, que permite ao relator relevar a pena de deserção quando o recorrente comprovar justo impedimento.

$\S 6$. $^{\circ}$ Provando o recorrente justo impedimento, o relator relevará a pena de deserção, por decisão irrecorrível, fixando-lhe prazo de cinco dias para efetuar o preparo.

§ 7. ${ }^{\circ}$ - Este parágrafo demonstra que qualquer equívoco verificado no preenchimento da guia de custas não implica pena de deserção, havendo oportunidade para o interessado sanar o vício.

$\S$ 7. ${ }^{\circ}$ O equívoco no preenchimento da guia de custas não implicará a aplicação da pena de deserção, cabendo ao relator, na hipótese de dúvida quanto ao recolhimento, intimar o recorrente para sanar o vício no prazo de cinco dias.

f) Art. 1.030 - Este artigo estabelece o rol dos documentos que devem instruir a petição de agravo de instrumento.

Art. 1.030. A petição de agravo de instrumento será instruída: 


\section{$[\ldots]$}

§ 2. ${ }^{\circ}$, II - O inciso II do § 2. ${ }^{\circ}$ do artigo 1.030 estabelece que o recurso será interposto por protocolo realizado na própria comarca, o que flexibiliza o protocolo integrado, acabando com qualquer dúvida quanto a aceitação ou não desse tipo de protocolo que foi objeto de jurisprudência defensiva:

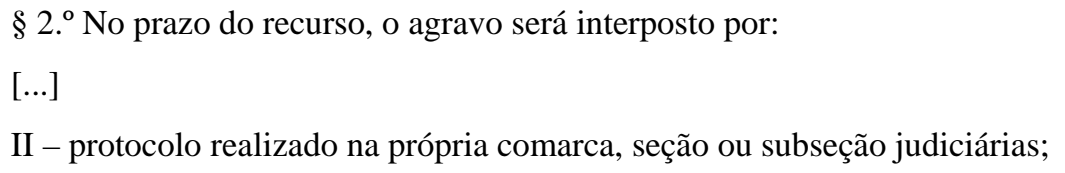

$\S 2 .^{\circ}$, III - O inciso III estabelece que o recurso de agravo pode ser proposto por postagem, sob registro com aviso de recebimento.

$$
\text { III - postagem, sob registro com aviso de recebimento; }
$$

Aqui paira uma dúvida, que deve ser esclarecida pelo legislador, no tocante à data da postagem ser considerada como data do protocolo, uma vez que a jurisprudência defensiva afirma que o que vale é a data que o recurso adentra no tribunal, quando no nosso sentir o mais lógico seria considerar a data da postagem.

§ 3. ${ }^{\mathbf{0}}$ - Estabelece a possibilidade de juntada de peças ausentes no prazo de cinco dias, conforme estabelecido no parágrafo único do artigo 945, retrotranscrito:

$\S 3 .^{\circ} \mathrm{Na}$ falta da cópia de qualquer peça ou no caso de algum outro vício que comprometa a admissibilidade do agravo de instrumento, deve o relator aplicar o disposto no art. 945, parágrafo único.

g) Art. 1.034 - Este artigo nomina “agravo interno” o recurso contra decisão proferida pelo relator, diferenciando-o do agravo de instrumento, acabando com os apelidos atualmente existentes: “agravo regimental”, “agravinho” e “agravo interno”. respectivo órgão colegiado, observadas, quanto ao processamento, as regras do regimento interno do tribunal. 
$\S 3 .^{\circ}$ - Este parágrafo veda ao relator julgar improcedente o agravo interno, com a simples reprodução do julgado.

$\S 3 .^{\circ}$ É vedado ao relator se limitar à reprodução dos fundamentos da decisão agravada para julgar improcedente o agravo interno.

§ 4. ${ }^{\circ}$ - Estabelece multa de $1 \%$ a $5 \%$ do valor da causa atualizado, a favor do agravado, quando o agravo for declarado manifestamente inadmissível ou improcedente por votação unânime. No nosso entendimento, essa previsão levará o interessado em recorrer a pensar se realmente deve exercer o seu direito de fazê-lo.

$\S 4 .^{\circ}$ Quando o agravo interno for declarado manifestamente inadmissível ou improcedente em votação unânime, o órgão colegiado, em decisão fundamentada, condenará o agravante a pagar ao agravado multa fixada entre um e cinco por cento do valor da causa atualizado.

h) Art. 1.037, $\S$ 1. $^{\circ}$ - Estabelece que os embargos de declaração em sede recursal serão apresentados pelo relator na sessão subsequente e será decidido monocraticamente.

Art. 1.037. O juiz julgará os embargos em cinco dias; nos tribunais, o relator apresentará os embargos em mesa na sessão subsequente, proferindo voto. Não havendo julgamento nessa sessão, será o recurso incluído em pauta automaticamente.

$\S 1 .^{\circ}$ Quando os embargos de declaração forem opostos contra decisão de relator ou outra decisão unipessoal proferida em tribunal, o órgão prolator da decisão embargada decidi-los-á monocraticamente.

$\S 2 .^{\circ}$ - Se o órgão julgador (relator) entender que é caso de agravo interno, intimará o recorrente para completar as razões recursais e ajustá-las, às exigências do art. 1.034, § $1 .^{\circ}$

§ 2. ${ }^{\circ} \mathrm{O}$ órgão julgador conhecerá dos embargos de declaração como agravo interno se entender ser este o recurso cabível, desde que determine previamente a intimação do recorrente para, no prazo de cinco dias, complementar as razões recursais, de modo a ajustá-las às exigências do art. 1.034, § 1. .

§ 4. ${ }^{\text {- }}$ - Prevê o afastamento da necessidade de ratificação de recurso interposto anteriormente ao julgamento de embargos de declaração apostos pela parte contrária, quando não é alterada a conclusão do julgamento da decisão embargada. Esse dispositivo determina a desnecessidade de ratificação de recurso interposto antes do 
julgamento dos embargos, o que corrobora com o nosso entendimento de estancar o formalismo que existe atualmente nessa hipótese:

$\S 4 .^{\circ}$ Se os embargos de declaração forem rejeitados ou não alterarem a conclusão do julgamento anterior, o recurso interposto pela outra parte, antes da publicação do julgamento dos embargos de declaração, será processado e julgado independentemente de ratificação.

\subsection{Tentativa de equilíbrio}

O recorrente muitas vezes se depara com o seu intento tolhido por questões processuais e entendimentos pessoais de cada julgador em razão de seu recurso não ultrapassar o juízo de admissibilidade. Isso ocorre sem que tenha a possibilidade de esclarecer simples erros ou equívocos, o que o leva a utilizar todos os remédios recursais que o legislador lhe coloca à disposição.

A interposição de sucessivos recursos gera um tumulto em nossos tribunais, provocando não somente um caos no órgão judiciário, pelo grande número de recursos interpostos, diante do número limitado de julgadores, além da demora da decisão, e, muitas vezes mesmo enfrentando a morosidade, o interessado na pacificação do conflito vê o seu processo, por entraves processuais, tomar um novo rumo, que o distancia do litígio original, ou seja, as disputas processuais passam a ser o foco principal do processo e o litígio que levou o interessado a propor a ação é deixado de lado.

Não somente as disputas processuais, mas também o mal da morosidade da justiça brasileira, não serão sanados com a simples reforma processual, visto que passa por deficiências estruturais e de gestão do serviço público judiciário, pela formação excessivamente formalista e contenciosa dos operadores do direito e pela indevida utilização do órgão judiciário como instrumento de moratória da dívida pública, mas há de reconhecer que são propostas importantes e positivas. ${ }^{504}$

Essa nova versão do projeto do Novo Código de Processo Civil (PL n. ${ }^{\circ}$ 8.046/2010), aprovada pela Câmara dos Deputados em 26.03.2014, não resolverá todos os problemas, mas diminuirá o formalismo na admissibilidade dos recursos, principalmente

${ }^{504}$ DELLORE, GAJARDONI; OLIVEIRA JUNIOR et ROQUE, 2013. 
nos tribunais superiores, apontados neste estudo, pois inibirá a prática da jurisprudência defensiva atualmente em voga.

O novo projeto, de um lado, inibe a interposição de sucessivos embargos declaratórios, que atualmente são ilimitados, restringindo-os em dois, por parte dos interessados, além de punir os recursos interpostos com fins meramente protelatórios, estabelecendo multas, cuja base de cálculo é o valor atualizado da causa, o que se pode verificar nos seguintes artigos: 1.039 e parágrafos, e 1.034 e parágrafos.

De outro lado, impede o formalismo exacerbado consubstanciado na jurisprudência defensiva, coibindo os órgãos julgadores de prolatar decisões terminativas, muitas vezes fundadas em puro formalismo excessivo, ou entendimentos unipessoais.

É certo que quem procura a justiça para a solução de um litígio o faz com a finalidade de obter uma sentença de mérito, ou seja, espera que o julgador na decisão aponte a qual das partes pertence o bem da vida, e, obviamente, fica insatisfeito quando entraves processuais passam a ser o centro da atenção do processo, deixando em segundo plano a questão que deu origem à ação.

Além disso, muitas vezes, esses entraves processuais que passam a ser o foco do processo prolongam demasiadamente o andamento processual, trazendo uma solução tardia ao litígio, eternizando demandas consideradas simples, o que aumenta a insatisfação.

Essas situações de demasiada demora processual, mudança de foco do processo para assuntos processuais e decisões terminativas sem apreciação do mérito da causa trazem a falta de credibilidade do órgão judiciário, e é nesse sentido que entendemos que o formalismo exacerbado deve ser eliminado e a técnica processual deve ser flexibilizada em sede recursal, devendo ser aplicada para a obtenção de um julgamento de mérito, no maior número de casos possíveis, para que as decisões passem a pacificar as situações da vida.

Em nosso sentir, se esse projeto de lei vier a ser definitivamente aprovado e entrar em vigor, propiciará maior equilíbrio e contribuirá com a mitigação do excesso de formalismo que atualmente impera na admissibilidade dos recursos, como também inibirá a propositura de recursos protelatórios, o que trará uma diminuição do número de processos que são protocolados anualmente nos tribunais superiores. 


\section{CONSIDERAÇÕES FINAIS}

Reforçando o que já foi exposto no corpo deste trabalho, externamos nosso entendimento de que o rigor com que os recursos são analisados no juízo de admissibilidade deve ser flexibilizado principalmente com a eliminação da jurisprudência defensiva que, além de criar insatisfação daqueles que procuram a justiça para dirimir as controvérsias que surgem no quotidiano, também diminui a credibilidade do Poder Judiciário.

O direito processual é instrumento do direito substancial e em hipótese alguma poderá passar a ser o foco central do processo, cuja finalidade é pacificar o litígio levado a juízo. O cerne do direito material em que se funda o pedido do autor deverá sempre ser o centro da atenção do processo, visto que o instrumento é apenas meio de conduzir o processo para que a decisão dê o bem da vida a quem demonstre ser o seu detentor.

É fato que os tribunais superiores, abarrotados de processos, encontram-se em crise, haja vista a disparidade entre o número de recursos distribuídos anualmente e a sua capacidade em número de decisões, mas isso não é justificativa para negar a justiça a quem a procura.

Também faz-se indispensável uma conscientização dos operadores do direito na orientação de sua clientela, no sentido de estancar a escala recursal quando não for realmente necessária, contribuindo assim com a diminuição de oposição de recursos sucessivos e infundados.

Aliás, o projeto do Novo Código de Processo Civil (PL n. ${ }^{\circ}$ 8.046/2010) já aprovado pela Câmara dos Deputados em 26.03.2014, caso entre em vigor, irá auxiliar na diminuição de recursos, principalmente aqueles repetitivos e sucessivos, visto que a nova lei complementar os limita.

Quanto ao formalismo no juízo de admissibilidade dos recursos, entendemos que a técnica processual deve ser aplicada de maneira mais flexível, com a possibilidade de sanar vícios passíveis de serem regularizados sem que haja prejuízo para as partes e sem prejuízo do andamento processual.

Em nosso sentir, os requisitos da tempestividade, regularidade formal e preparo devem ser analisados no juízo de admissibilidade com intuito de possibilitar ao máximo o 
conhecimento dos recursos, entregando a quem se socorre do Judiciário para dirimir uma controvérsia uma decisão de mérito.

Nessa linha de raciocínio, passaremos a pontuar algumas situações que entendemos devam ser reavaliadas no juízo de admissibilidade dos recursos nos tribunais superiores.

Na questão do requisito da tempestividade não deve ser considerado prematuro ou inexistente o recurso especial ou extraordinário protocolado anteriormente à publicação do acórdão recorrido, pois a finalidade da publicação do acórdão é dar ciência às partes do conteúdo decisivo e se o interessado em recorrer tomou ciência da decisão por outros meios, a sua finalidade, ou seja, a ciência da decisão foi atingida, não sendo justa a inadmissibilidade do recurso que consubstancia punição da parte que foi diligente em seu direito de recorrer.

Ainda quanto ao requisito da tempestividade, a data da postagem do recurso enviado ao tribunal via correio, deve ser considerada como data efetiva de protocolo, pois houve flexibilização por parte do tribunal na aceitação do envio do recurso pelo correio, torna-se sem sentido desconsiderar a data de sua postagem, mesmo porque o recorrente cumpriu o prazo, preparando as razões recursais a tempo e não pode ficar à mercê da eficiência do serviço postal para a aferição da tempestividade. Isso irá corroborar com a celeridade processual, pois a inadmissibilidade do recurso pela desconsideração da data de sua postagem no correio gera a indignação do recorrente, o que o impele à propositura de novos recursos, quando a simples aceitação, ou a mudança da data do protocolo, considerando-se a data da postagem do recurso, trará mais eficiência ao sistema recursal.

Quanto ao requisito da regularidade formal, não pode ser considerado inexistente recurso que contém vício na representação processual, sem que antes seja dada chance ao recorrente para regularizar a representação, pois a lei processual admite a regularização da representação e não exclui os tribunais superiores, constituindo-se formalismo excessivo a exclusão das Cortes mais elevadas do País, as quais deveriam servir de exemplo. A solução é dar oportunidade para que a parte corrija a omissão e faça a juntada do instrumento de procuração para a correção do defeito de representação, pois cabe às Cortes excepcionais o controle da aplicação correta da lei infraconstitucional, sendo incompatível com o seu dever a sua própria exclusão, ou seja, a lei deve ser válida não somente para os jurisdicionados, como também para os aplicadores do direito, em todas as instâncias. 
Também no caso de pedido de assistência judiciária ter sido feito no ato de interposição do recurso, ou seja, no corpo das razões recursais, tal fato não deve obstar o conhecimento do recurso com a justificativa de que a concessão da assistência judiciária não teria efeito retroativo, efetuando o juízo de admissibilidade negativo do recurso por ausência de preparo, pois, se o recorrente alega e prova que não tem condições financeiras de suportar as despesas processuais, negar-lhe conhecimento sumariamente traduz-se em coibição ao seu acesso à justiça. Obviamente, se depois de uma análise mais aprofundada das provas da sua impossibilidade financeira ficar evidenciado que ele pode arcar com as custas processuais, sem prejuízo próprio e de sua família, deve ser indeferido tal pedido, porém deverá ser aberto prazo para que ele efetue o recolhimento das custas sob pena de deserção, pois negar-lhe conhecimento de plano evidencia excesso de formalismo. Nesse caso, a análise da questão no juízo de admissibilidade deve ser feita com a aplicação do artigo 244 do Código de Processo Civil, pois o pedido de assistência judiciária no corpo do recurso alcançou a sua finalidade sem que tenha trazido prejuízo à outra parte. Além disso, a forma prescrita na regra do artigo $6 .^{\circ}$ da Lei 1.060/1950 não prevê qualquer cominação de nulidade, se o pedido for realizado de forma diversa.

Outra exigência que a nosso ver constitui formalismo excessivo e deve, por isso, ser flexibilizada é a inadmissibilidade do recurso por faltar legibilidade no carimbo aposto por funcionários do Poder Judiciário no ato do protocolo do recurso. Se há dúvida quanto à data, esta não foi gerada pelo recorrente que, nesse caso, encontra-se em estado de hipossuficiência, devendo a dúvida ser sanada junto ao protocolo do tribunal de origem, mas nunca transformar em vítima o recorrente com a inadmissibilidade do recurso, por mera suposição de intempestividade.

Quanto ao não conhecimento do recurso em razão do esquecimento do advogado em assinar as razões, quando consta a sua assinatura na petição de apresentação do recurso, ou quando a tenha assinado eletronicamente, deverá ser dada oportunidade para que o ele assine as razões, pois esses vícios são perfeitamente supríveis em todas as instâncias.

Quanto ao requisito preparo recursal, a sua finalidade precípua é ressarcir aos cofres públicos as despesas processuais. Se o recorrente recolhe aos cofres públicos o valor do preparo no prazo recursal, cumpriu a sua obrigação. Se protocolar o recurso e posteriormente comprovar o recolhimento do preparo, não modifica o fato de que o cumprimento da obrigação foi tempestivo, mesmo porque não há qualquer prejuízo seja ao erário, seja a qualquer das partes, o que torna formalismo excessivo a não aceitação da 
comprovação do preparo posteriormente ao protocolo do recurso, mesmo dentro do prazo recursal.

Ainda quanto ao requisito preparo, quando a um recurso for denegado o seguimento no juízo de admissibilidade, seja pelo órgão a quo, seja pelo órgão ad quem, normalmente o recorrente já recolheu aos cofres públicos as custas judiciais e o porte de remessa e retorno dos autos ao tribunal. Nesse caso, o serviço não foi prestado ou foi prestado parcialmente, e seria justo que o juiz ou o relator julgasse a questão da repetição do indébito integral ou parcial, dependendo do serviço prestado pelo órgão jurisdicional ao contribuinte, no caso, ao recorrente, pois, em nosso sentir, é injusto o pagamento integral de um serviço judiciário que não foi prestado, visto inexistir o fato gerador de sua incidência. Essa repetição que se propõe tem como base o § 7. do artigo 150 da Constituição Federal:

A Lei poderá atribuir a sujeito passivo de obrigação tributária a condição de responsável pelo pagamento de imposto ou contribuição, cujo fato gerador deva ocorrer posteriormente, assegurada a imediata e preferencial restituição da quantia paga, caso não se realize o fato gerador presumido.

Quanto ao preenchimento das guias de preparo, é formalismo exacerbado a sua não aceitação quando a GRU estiver preenchida de forma manuscrita. Se a guia foi preenchida e encontra-se legível, é inconcebível a sua não aceitação sob a presunção de que a parte utiliza a mesma guia em vários processos. Aqui o tribunal está presumindo a má-fé do recorrente, quando é a boa-fé que deve ser presumida. Se posteriormente for comprovada a suspeita da utilização da guia em outro processo, deve-se punir o litigante com as penalidades previstas nos artigos 17 e 18 do Código de Processo Civil, mas nunca generalizar e punir um litigante inocente por mera presunção.

Outra questão que se coloca ainda em relação ao preparo é a não aceitação da quitação das guias de custas eletronicamente, pois, se o Judiciário já tem implantado o processo eletrônico e os pagamentos, via internet, são aceitáveis em todo o País, uma vez que a rede bancária é toda informatizada e o próprio Judiciário nas instâncias inferiores aceita a utilização dessa forma de pagamento, constitui-se mero formalismo a não aceitação do pagamento das custas via internet, pelos tribunais superiores.

Em nosso entendimento, o formalismo processual é necessário e nunca poderá ser desconsiderado, porém deverá sempre ser aplicado com bom senso, ou seja, sem transformar a técnica processual no objetivo principal do processo, em detrimento do 
direito material almejado por quem procura o Judiciário para solucionar um litígio, ainda que esse processo esteja no âmbito recursal, em que o juízo de admissibilidade deve ser realizado com flexibilização da técnica processual, com intuito de garantir que seja analisado o mérito, no maior número de casos possível, visando ao alcance de decisões que pacifiquem as situações da vida. 


\section{REFERÊNCIAS BIBLIOGRÁFICAS}

ALEXANDER, Larry. Comigo é tudo ou nada, formalismo no direito e na moralidade. Tradução de Thalia Simões Cerqueira. In: RODRIGUEZ, José Rodrigo (Org.). A justificação do formalismo jurídico. São Paulo: Saraiva, 2011.

ALVIM, Thereza. Questões prévias e os limites objetivos da coisa julgada. São Paulo: RT, 1977.

AMARAL SANTOS, Moacyr. Primeiras linhas de direito processual civil. 18. ed. São Paulo: Saraiva, 1997. v. 3.

APRIGLIANO, Ricardo de Carvalho. A apelação e seus efeitos. São Paulo: Atlas, 2007.

ARAÚJO, Fábio Caldas. Breves considerações sobre o agravo (instrumento e retido). In: MEDINA, José Miguel Garcia; CRUZ, Luana Pedrosa de Figueiredo; CERQUEIRA, Luíz Otávio Sequeira de; GOMES JÚNIOR, Luiz Manoel (Coord.). Os poderes do juiz e o controle das decisões judiciais. Estudos em homenagem à Professora Teresa Arruda Alvim Wambier. São Paulo: RT, 2008.

ARMELIN, Donaldo. Apontamentos sobre as alterações ao Código de Processo Civil e à Lei 8.038/90, impostas pela Lei 9.756/98. In: NERY JR., Nelson; WAMBIER, Teresa Arruda Alvim (Coord.). Aspectos polêmicos e atuais dos recursos cíveis de acordo com a Lei 9.756/98. São Paulo: RT, 1999.

ARRUDA ALVIM, Eduardo. Recurso especial e recurso extraordinário. In: NERY JR., Nelson; WAMBIER, Teresa Arruda Alvim (Coord.). Aspectos polêmicos e atuais dos recursos cíveis de acordo com a Lei 10.352/2001. São Paulo: RT, 2002. v. 5, p. 135-168.

ARRUDA ALVIM, José Manuel. Anotações sobre a teoria geral dos recursos. In: NERY JR., Nelson; WAMBIER, Teresa Arruda Alvim (Coord.). Aspectos polêmicos e atuais dos recursos cíveis de acordo com a Lei 9.756/98. São Paulo: RT, 1999.

- Manual de direito processual civil. 3. ed. São Paulo: R. dos Tribunais, v. 1, 1994.

- Notas sobre algumas das mutações verificadas com a Lei 10.352/2001. In: NERY JR. Nelson; WAMBIER, Teresa Arruda Alvim (Coord.). Aspectos polêmicos e 
atuais dos recursos cíveis e de outros meios de impugnação às decisões judiciais. São Paulo: RT, 2002. v. 6.

- Súmula e súmula vinculante. In: MEDINA, José Miguel Garcia; CRUZ, Luana Pedrosa de Figueiredo; CERQUEIRA, Luiz Otávio Sequeira de GOMES JÚNIOR, Luiz Manoel (Coord.). Os poderes do juiz e o controle das decisões judiciais. Estudos em homenagem à Professora Teresa Arruda Alvim Wambier. São Paulo: RT, 2008.

—. STF rumo à flexibilização da jurisprudência defensiva. Disponível em: <http://www.oab.org.br/util/print/24648?print=Noticia>. Acesso em: 26 fev. 2014.

ARRUDA ALVIM, Teresa. Despachos, pronunciamentos recorríveis? Revista de Processo, São Paulo, n. 58, p. 50, 1990.

ASSIS, Araken de. Condições de admissibilidade dos recursos cíveis. In: NERY JR., Nelson; WAMBIER, Teresa Arruda Alvim (Coord.). Aspectos polêmicos e atuais dos recursos cíveis de acordo com a Lei 9.756/98. São Paulo: RT, 1999. p. 11-51.

—. Manual dos recursos. 2. ed. São Paulo: RT, 2008.

AZEM, Guilherme Beux Nassif. A nova disciplina do agravo. In: NERY JR., Nelson; WAMBIER, Teresa Arruda Alvim (Coord.). Aspectos polêmicos e atuais dos recursos cíveis e assuntos afins. São Paulo: RT, 2007. v. 11.

AZEVEDO, Luiz Carlos de; CRUZ E TUCCI, José Rogério. Lições de história do processo civil lusitano. São Paulo: RT; Coimbra: Coimbra Editora, 2009.

BALZANO, Nicola. Acquiescenza, parti di sentenza e questioni relevabili d'ufficio. Rivista di Diritto Processuale, Padova, v. 6, parte II, p. 217-218, 1951.

BARBOSA MOREIRA, José Carlos. —— O juízo de admissibilidade no sistema dos recursos cíveis. 1968. Tese (Livre-docência de direito judiciário civil) - Rio de Janeiro.

— O novo processo civil brasileiro. 16. ed. Rio de Janeiro: Forense, 1994a. - A efetividade do processo de conhecimento. Revista de Processo, São Paulo, ano 19, n. 74, p. 128, 1994b.

—. Juízo de admissibilidade e juízo de mérito no julgamento do recurso especial. Temas de direito processual. Quinta Série. São Paulo: Forense, 1994c. 
- Notas sobre alguns fatores extrajurídicos no julgamento colegiado. Revista de Processo, São Paulo, ano 19, n. 75, 1994d.

— Correlação entre pedido e a sentença. Revista de Processo, São Paulo: RT, n. 83, p. 214-215, jul.-set. 1996.

—. Inovações da Lei 9.756 em matéria de recursos cíveis. In: NERY JR., Nelson; WAMBIER, Teresa Arruda Alvim (Coord.). Aspectos polêmicos e atuais dos recursos cíveis de acordo com a Lei 9.756/98. São Paulo: RT, 1999.

— - O futuro da justiça: alguns mitos. Temas de direito processual. Oitava série. São Paulo: Saraiva. 2004a.

—. Reformas do CPC em matéria de recursos. Temas de direito processual. Oitava série. São Paulo: Saraiva, 2004b.

—. O problema da duração dos processos: premissas para uma discussão séria. Temas de direito processual. Nona série. São Paulo: Saraiva, 2007a.

—. Restrições ilegítimas ao conhecimento dos recursos. Temas de direito processual. Nona série. São Paulo: Saraiva, 2007b.

—. Comentários ao Código de Processo Civil. 15. ed. Rio de Janeiro: Forense, v. 5, 2010.

BARIONI, Rodrigo. A proibição da reformatio in peius e o $\S 3 .^{\circ}$ do art. 515 do CPC. In: NERY JR., Nelson; ALVIM WAMBIER, Teresa Arruda (Coord.). Aspectos polêmicos e atuais dos recursos cíveis. São Paulo: RT, 2005. v. 8.

BEDAQUE, José Roberto dos Santos. Algumas considerações sobre o cumprimento de sentença condenatória. Revista do Advogado, São Paulo, ano XXVI, n. 85, p. 63-76, 2006.

—. Apelação: questões sobre admissibilidade e efeitos. In: NERY JR., Nelson; WAMBIER, Teresa Arruda Alvim (Coord.). Aspectos polêmicos e atuais dos recursos cíveis e de outros meios de impugnação a decisões judiciais. São Paulo: RT, 2003. v. 7.

—. Código de Processo Civil interpretado. Organização de Antonio Carlos Marcato. São Paulo: Atlas, 2004.

—. Direito e processo. 6. ed. São Paulo: Malheiros, 2011. 
— Efetividade e técnica processual. 3. ed. São Paulo: Malheiros, 2010.

—. Nulidades processuais e apelação. Revista de Direitos e Garantias Fundamentais, Vitória, n. 1, p. 225-254, 2006.

BONDIOLI, Luiz Guilherme Aidar. Breves notas sobre o controle das decisões monocráticas na instância recursal. Disponível em: $<$ http://www.tex.pro.br/tex/listagem-de-artigos/324-artigos-abr-2011/8040-brevesnotas-sobre-ocontrole-das-decisoes-monocraticas-na-instancia-recursal>. Acesso em: 27 dez. 2011.

BONICIO, Marcelo José Magalhães. Capítulos de sentença e efeitos dos recursos. São Paulo, RCS Editora, 2006.

BRUSCHI, Gilberto Gomes; NOTARIANO JR., Antonio. Agravo contra as decisões de primeiro grau. São Paulo: Método, 2006.

BUENO, Cassio Scarpinela. A nova etapa da reforma do Código de Processo Civil. 2. ed. São Paulo: Saraiva, 2006. v. 1.

Curso sistematizado de direito processual civil. 2. ed. São Paulo: Saraiva, 2010.

BUIKA, Heloisa Leonor. Processo eletrônico. Revista Síntese Direito Civil e Processual Civil, São Paulo, ano XII, n. 81, p. 117, jan.-fev. 2013.

CALMON DE PASSOS, J. J. O recurso extraordinário e a emenda n. 3 do Regimento Interno do Supremo Tribunal Federal. Revista de Processo, São Paulo, ano II, n. 5, p. $45,1977$.

CÂMARA, Alexandre Freitas. O agravo interno no direito processual civil brasileiro. In: MEDINA, José Miguel Garcia; CRUZ, Luana Pedrosa de Figueiredo; CERQUEIRA, Luiz Otávio Sequeira de; GOMES JÚNIOR, Luiz Manoel (Coord.). Os poderes do juiz e o controle das decisões judiciais. Estudos em homenagem à Professora Teresa Arruda Alvim Wambier. São Paulo: RT, 2008.

CAMBI, Accácio. Aspectos polêmicos na aplicação do art. 557 do CPC. In: NERY JR., Nelson; WAMBIER, Teresa Arruda Alvim (Coord.). Aspectos polêmicos e atuais dos recursos cíveis e de outros meios de impugnação a decisões judiciais. São Paulo: RT, 2003. v. 7. 
CAMBI, Eduardo. Efeito devolutivo da apelação e duplo grau de jurisdição. In: MARINONI, Luiz Guilherme; DIDIER JR., Fredie. (Coord.). A segunda etapa da reforma processual civil. São Paulo: Malheiros, 2001.

CAPPELLETTI, Mauro. Parere iconoclastico sulla riforma del processo civile italiano. Giustizia e società. Milano: Edizioni di Comunità, 1972..

—; BRYANT, Garth. Acesso à justiça. Tradução de Allen Gracie Northfleet. Porto Alegre: Fabris, 2002.

CARMONA, Carlos Alberto. O sistema recursal brasileiro: breve análise crítica. In: NERY JR., Nelson; ARRUDA ALVIM, Eduardo Pellegrini de; WAMBIER, Teresa Arruda Alvim (Coord.). Aspectos polêmicos e atuais dos recursos. São Paulo: RT, 2000.

CARNEIRO, Athos Gusmão. Anotações sobre o recurso especial. In: TEIXEIRA, Sálvio de Figueiredo (Coord.). Recursos no Superior Tribunal de Justiça. São Paulo: Saraiva, 1991.

- Do recurso de agravo ante a Lei 11.187/2005. Revista Jurídica, Porto Alegre, ano 54, n. 339, jan. 2005.

—. Poderes do relator e agravo interno - artigos 557, 544 e 545 do CPC. Revista Jurídica, Porto Alegre, ano 48, p. 7, ago. 2000.

CARNEIRO DA CUNHA, Leonardo José. Evoluções e involuções do agravo. In: NERY JR., Nelson; WAMBIER, Teresa Arruda Alvim (Coord.). Aspectos polêmicos e atuais dos recursos cíveis e assuntos afins. São Paulo: RT, 2007. v. 9.

—. Sanação de defeitos processuais no âmbito recursal. In: MEDINA, José Miguel Garcia; CRUZ, Luana Pedrosa de Figueiredo; CERQUEIRA, Luiz Otávio Sequeira de; GOMES JÚNIOR, Luiz Manoel (Coord.). Os poderes do juiz e o controle das decisões judiciais. Estudos em homenagem à Professora Teresa Arruda Alvim Wambier. São Paulo: RT, 2008.

CARNELUTTI, Francesco. Appello civile. Enciclopedia italiana. Milano: Casa Editrice Bestetti \& Tumminelli, 1939.

—. Diritto e processo. Padova: Morano, 1959.

— Lezioni di diritto processuale civili. Padova: Cedam, 1925. v. 4. 
CARPI, Federico. L'accesso alla Corte di Cassazione italiana e alle Corti Supreme dei Paesi Europei. Revista de Processo, São Paulo, ano 37, v. 204, p. 198, fev. 2012.

—. L'acesso alla Corte di Cassazione ed il nuovo sistemi di filtri. Rivista Trimestrale di Diritto e Procedura Civile, Milano, anno LXIV, n. 3, p. 774-775, 2010.

CARREIRA ALVIM, J.E.; CABRAL, Luciana Gontijo Carreira Alvim. Nova mexida nos agravos retido e de instrumento. In: NERY JR., Nelson; WAMBIER, Teresa Arruda Alvim (Coord.). Aspectos polêmicos e atuais dos recursos cíveis e assuntos afins. São Paulo: RT, 2007. v. 9.

CARVALHO, Fabiano. Poderes do relator nos recursos art. 557 do CPC. São Paulo: Saraiva, 2008.

CAVALCANTE, Mantovanni Colares. Os meios de controle das decisões monocráticas do relator nos tribunais. In: MEDINA, José Miguel Garcia; CRUZ, Luana Pedrosa de Figueiredo; CERQUEIRA, Luiz Otávio Sequeira de; GOMES JÚNIOR, Luiz Manoel (Coord.). Os poderes do juiz e o controle das decisões judiciais. Estudos em homenagem à Professora Teresa Arruda Alvim Wambier. São Paulo: RT, 2008.

CHASE, Oscar G. Civil litigation delay in Italy and the United States. The American Journal of Comparative Law, v. 36, n. 1, p. 41-47, Winter 1988.

CHEIM JORGE, Flávio. Apelação cível: teoria geral e admissibilidade. São Paulo: RT, 2002.

—. Apontamentos sobre a tempestividade recursal: fluência inequívoca; recurso interposto antes da intimação; interrupção do prazo por força da interposição de embargos de declaração. Revista de Processo, São Paulo, ano 35, n. 181, p. 175, mar. 2010.

—. Requisitos de admissibilidade dos recursos entre a relativização e as restrições indevidas (jurisprudência defensiva). In: OLIVEIRA, Bruno Silveira de; CHEIM JORGE, Flávio; RODRIGUES, Marcelo Abelha; NOLASCO, Rita Dias; MAZZEI, Rodrigo (Coord.). Recursos e a duração razoável do processo. Brasília: Gazeta Jurídica, 2013.

Teoria geral dos recursos cíveis. 4. ed. São Paulo: RT, 2009. 
; RODRIGUES, Marcelo Abelha. A sentença, a interlocutória e os recursos. In: MEDINA, José Miguel Garcia; CRUZ, Luana Pedrosa de Figueiredo; CERQUEIRA, Luiz Otávio Sequeira de; GOMES JÚNIOR, Luiz Manoel (Coord.). Os poderes do juiz e o controle das decisões judiciais. Estudos em homenagem à Professora Teresa Arruda Alvim Wambier. São Paulo: RT, 2008.

—; SANTANA, Felipe Teles. Uma análise crítica sobre o recurso especial e o conhecimento das matérias de ordem pública. Revista de Processo, São Paulo, ano 37, v. 213, 2012.

CHIOVENDA, Giuseppe. Principii di diritto processuale civile. 4. ed. Napoli: Jovene, 1928. § 43.

CINTRA, Carlos de Araújo; DINAMARCO, Cândido Rangel; GRINOVER, Ada Pellegrini. Teoria geral do processo. 26. ed. São Paulo: Malheiros, 2010. p. 56.

COMOGLIO, Luigi Paolo. Accesso alle corti e garanzie costituzionale. In: YARSHELL, Flávio Luiz; MORAES, Maurício Zanoide de (Org.). Estudos em homenagem à Professora Ada Pellegrini Grinover. São Paulo: DPJ Editora, 2005.

—. Garanzie costituzionali e "giusto processo" (modelli a confronto). Revista de Processo, ano 23, n. 90, p. 115, abr.-jun. 1998.

_ Il doppio grado di giudizio nelle prospettive di revisione costituzionale. Rivista di Diritto Processuale, Padova: Cedam, seconda serie, n. 2, p. 328, apr.-giu. 1999.

CÔRTES, Osmar Mendes Paixão. As nulidades acolhidas pelos tribunais superiores em recursos de natureza extraordinária - necessidade ou formalismo? In: MEDINA, José Miguel Garcia; CRUZ, Luana Pedrosa de Figueiredo; CERQUEIRA, Luiz Otávio Sequeira de; GOMES JÚNIOR, Luiz Manoel (Coord.). Os poderes do juiz e o controle das decisões judiciais. Estudos em homenagem à Professora Teresa Arruda Alvim Wambier. São Paulo: RT, 2008.

COUTURE, Eduardo J. Fundamentos del derecho procesal civil. Buenos Aires: Depalma, 1958.

CRUZ E TUCCI, José Rogério. Garantia do processo sem dilações indevidas. In:

(Coord.). Garantias constitucionais do processo civil. São Paulo: RT, 1999.

—. Lineamentos da nova reforma do CPC. 2. ed. São Paulo: Malheiros, 2002. 
Sobre a atividade decisória do relator do agravo de instrumento. Revista do Advogado, São Paulo, n. 48, jul. 1996.

- Tempo e processo. São Paulo: RT, 1997.

DELLORE, Luiz Guilherme Pennachi. Do recurso cabível das decisões referentes à gratuidade da justiça (Lei 1060/1950). NERY JR., Nelson; WAMBIER, Teresa Arruda Alvim (Coord.). Aspectos polêmicos e atuais dos recursos cíveis e assuntos afins. São Paulo: RT, 2006. v. 9.

— ; GAJARDONI, Fernando da Fonseca; OLIVEIRA JUNIOR, Zulmar Duarte de; ROQUE, Andre Vasconcelos. A jurisprudência defensiva ainda pulsa no novo CPC. Disponível em: <http://www.conjur.com.br/2013-set-06/jurisprudencia-defensivaainda-pulsa-codigo-processo-civil>. Acesso em: $21 \mathrm{dez} .2013$.

DENTI, Vittório; TARUFFO, Michele. Costo e durata del processo civile in Itália. Rivista di Diritto Civile, Padova, anno XXXII, n. 3, p. 291, 1986.

DIAS, Maria Berenice. Agravo: alguns pontos controvertidos. Revista de Processo. São Paulo, ano 23, n. 92, p. 236-243, out.-dez. 1998.

—. Apelação versus agravo. In: NERY JR., Nelson; WAMBIER, Teresa Arruda Alvim (Coord.). Aspectos polêmicos e atuais dos recursos cíveis e de outros meios de impugnação às decisões judiciais. São Paulo: RT, 2005. v. 8.

DIDIER JR., Fredie. O recurso extraordinário e a transformação do controle difuso de constitucionalidade no direito brasileiro. In: OLIVEIRA, Bruno Silveira de; CHEIM JORGE, Flávio; RODRIGUES, Marcelo Abelha; NOLASCO, Rita Dias; MAZZEI, Rodrigo (Coord.). Recursos e a duração razoável do processo. Brasília: Gazeta Jurídica, 2013.

DINAMARCO, Cândido Rangel. A reforma do Código de Processo Civil. 2. ed. São Paulo: Malheiros, 1995.

—. O relator, jurisprudência e os recursos. In: NERY JR., Nelson; WAMBIER, Teresa Arruda Alvim (Coord.). Aspectos polêmicos e atuais dos recursos cíveis de acordo com a Lei 9.756/98. São Paulo: RT, 1999.

—. Os efeitos dos recursos. In: NERY JR., Nelson; WAMBIER, Teresa Arruda Alvim (Coord.). Aspectos polêmicos e atuais dos recursos cíveis. São Paulo: RT, 2002a, v. 5. 
—. A reforma da reforma. 3. ed. São Paulo: Malheiros, 2002b.

—. Tempestividade dos recursos. Revista Dialética de Direito Processual. São Paulo, n. 16, jul. 2004.

— Instituições de direito processual civil. São Paulo: Malheiros, 2009a. v. I e II. . A instrumentalidade do processo. 14. ed. São Paulo: Malheiros, $2009 \mathrm{~b}$.

—. Capítulos de sentença. 4. ed. São Paulo: Malheiros, 2009c.

ENCICLOPEDIA ITALIANA. Milano: Istituto Giovanni Treccani, 1939.

FARIA, José Eduardo. O Judiciário e o desenvolvimento socioeconômico. In: (Org.). Direitos humanos, direitos sociais e justiça. São Paulo: Malheiros, 1994.

FARIA, Marcio Carvalho. O formalismo exacerbado quanto ao preenchimento de guias de preparo. Revista de Processo. São Paulo, ano 36, v. 193, p. 233, mar. 2011.

FERNANDES, Antonio Scarance; GOMES, Antonio Magalhães; GRINOVER, Ada Pellegrini. As nulidades no processo penal. São Paulo: RT, 1997.

FERNANDES, Luís Eduardo Simardi. A irrecorribilidade da decisão que não conhece do recurso extraordinário por ausência da repercussão geral. In: MEDINA, José Miguel Garcia; CRUZ, Luana Pedrosa de Figueiredo; CERQUEIRA, Luiz Otávio Sequeira de; GOMES JÚNIOR, Luiz Manoel (Coord.). Os poderes do juiz e o controle das decisões judiciais. Estudos em homenagem à Professora Teresa Arruda Alvim Wambier. São Paulo: RT, 2008.

FERREIRA, Aurélio Buarque de Holanda. Dicionário Aurélio da língua portuguesa. Coordenação de Marina Baird Ferreira. 5. ed. Curitiba: Positivo, 2010.

FERREIRA, William Santos. Decisões do relator e a recorribilidade assegurada pelo parágrafo único do art. 527 do CPC - uma questão de perspectiva. In: MEDINA, José Miguel Garcia; CRUZ, Luana Pedrosa de Figueiredo; CERQUEIRA, Luiz Otávio Sequeira de; GOMES JÚNIOR, Luiz Manoel (Coord.). Os poderes do juiz e o controle das decisões judiciais. Estudos em homenagem à Professora Teresa Arruda Alvim Wambier. São Paulo: RT, 2008.

FIGUEIRA JÚNIOR, Joel Dias. A trama recursal no processo civil brasileiro e a crise da jurisdição estatal. Revista de Processo. São Paulo, n. 188, 2010. 
FRANÇOLIN, Wanessa de Cássia. O juízo de admissibilidade dos recursos especial e extraordinário exercido pelo Tribunal local. In: NERY JR., Nelson; WAMBIER, Teresa Arruda Alvim (Coord.). Aspectos polêmicos e atuais dos recursos cíveis. São Paulo: RT, 2006. v. 9.

FRANCO, Fernão Borba. Vicissitudes do duplo grau de jurisdição: o art. 515, § $3^{\circ}$, do CPC. In: MEDINA, José Miguel Garcia; CRUZ, Luana Pedrosa de Figueiredo; CERQUEIRA, Luiz Otávio Sequeira de; GOMES JÚNIOR, Luiz Manoel (Coord.). Os poderes do juiz e o controle das decisões judiciais. Estudos em homenagem à Professora Teresa Arruda Alvim Wambier. São Paulo: RT, 2008.

FRANCO MONTORO, Marcos André. Requisitos de admissibilidade do recurso especial. 2005. Dissertação (Mestrado) - USP, São Paulo.

FREIRE, Rodrigo da Cunha Lima. Prequestionamento implícito em recurso especial: posição divergente no STJ. In: NERY JR., Nelson; WAMBIER, Teresa Arruda Alvim (Coord.). Aspectos polêmicos e atuais dos recursos cíveis e de outras formas de impugnação às decisões judiciais. São Paulo: RT, 2001. v. 4.

FREITAS JUNIOR, Horival Marques de. Repercussão geral das questões fundamentais. 2014. Dissertação (Mestrado) - São Paulo: USP.

GAJARDONI, Fernando da Fonseca. Princípio constitucional da tutela jurisdicional sem dilações indevidas e o julgamento antecipadíssimo da lide. Revista IOB de Direito Civil e Processual Civil. São Paulo, ano VII, n. 45, p. 106, jan.-fev. 2007.

GALVÃO, Ilmar Nascimento. O Poder Judiciário. O recurso especial no Superior Tribunal de Justiça. In: TEIXEIRA, Sálvio de Figueiredo. Recursos no Superior Tribunal de Justiça. São Paulo: Saraiva, 1991.

GRECO FILHO, Vicente. Direito processual civil brasileiro. 20. ed. São Paulo: Saraiva, 2009.

- Questões sobre a Lei 9.756, de 17 de dezembro de 1998. In: NERY JR., Nelson; WAMBIER, Teresa Arruda Alvim (Coord.). Aspectos polêmicos e atuais dos recursos cíveis de acordo com a Lei 9.756/98. São Paulo: RT, 1999.

GRECO, Leonardo. Estudos de direito processual. Campos dos Goitacazes: Ed. Faculdade de Campos, 2005. (Coleção José do Patrocínio.) 
— Princípios de uma teoria geral dos recursos. Revista Eletrônica de Direito Processual. v. 5. Disponível em: <http://www.arcos.org.br/periodicos/revistaeletronica-de-direito-processual/volume-v/principios-de-uma-teoria-geral-dosrecursos>. Acesso em: 14 mar. 2013.

GRINOVER, Ada Pellegrini. Direito processual coletivo. In: LUCON, Paulo Henrique dos Santos (Coord.). Tutela coletiva. São Paulo: Atlas, 2006. p. 302-309.

—. Os princípios constitucionais e o Código de Processo Civil. São Paulo: Bushatsky, 1975.

HAAK, Susan. O crescimento do significado e os limites do formalismo: perspectivas pragmáticas na ciência e no direito. Tradução de Rachel Herdy. In: RODRIGUEZ, José Rodrigo (Org.). A justificação do formalismo jurídico. São Paulo: Saraiva, 2011.

HAZARD JR., Geoffrey C. Costo e durata del processo in Italia e in U.S.A. Rivista di Diritto Civile. Padova, anno XXXII, n. 3, p. 271-272, 1986.

HOFFMAN, Paulo. Uniformização de jurisprudência (de 1. ' grau). In: MEDINA, José Miguel Garcia; CRUZ, Luana Pedrosa de Figueiredo; CERQUEIRA, Luiz Otávio Sequeira de; GOMES JÚNIOR, Luiz Manoel (Coord.). Os poderes do juiz e o controle das decisões judiciais. Estudos em homenagem à Professora Teresa Arruda Alvim Wambier. São Paulo: RT, 2008.

JORGE, Mário Helton. Juízo (provisório) de admissibilidade da apelação. Isenção do preparo. Assistência judiciária gratuita. In: NERY JR., Nelson; WAMBIER, Teresa Arruda Alvim (Coord.). Aspectos polêmicos e atuais dos recursos cíveis de acordo com a Lei 10.352/2001. São Paulo: RT, 2001. v. 5.

KENNEDY, Duncan. Formalismo jurídico. Tradução de Sheila Stolz. In: RODRIGUEZ, José Rodrigo (Org.). A justificação do formalismo jurídico. São Paulo: Saraiva, 2011.

KOMATSU, Roque. Da invalidade no processo civil. São Paulo: RT, 1991.

LASPRO, Oreste Nestor de Souza. Duplo grau de jurisdição no direito processual civil. São Paulo: RT, 1995. 
LEONEL, Ricardo de Barros. Revisitando a teoria geral dos recursos: o efeito suspensivo. In: NERY JR., Nelson; WAMBIER, Teresa Arruda Alvim (Coord.). Aspectos polêmicos e atuais dos recursos cíveis e assuntos afins. São Paulo: RT, 2006. v. 9.

LIEBMAN, Enrico Tullio. Manual de direito processual civil. Tradução e notas de Cândido Rangel Dinamarco. 2. ed. Rio de Janeiro: Forense, 1985. v. 1.

LOBSENZ, James J. A constitution right to an appeal: guarding against unacceptable risks of erroneous conviction. Disponível em:

$<$ http://digitalcommons.law.seattleu.edu/cgi/viewcontent.cgi?article=1197\&context= sulr>. Acesso em: 15 ago. 2014.

LOPES, Bruno Vasconcelos Carrilho. A reformatio in peius no direito processual civil. In: NERY JR., Nelson; WAMBIER, Teresa Arruda Alvim (Coord.). Aspectos polêmicos e atuais dos recursos cíveis. São Paulo: RT, 2005. v. 8

LOPES, João Batista. Os poderes do juiz e o aprimoramento da prestação jurisdicional. Revista de Processo. São Paulo, ano IX, n. 35, p. 34, abr.-jun. 1984.

LOPES, Renan Kfuri. Lei n. ${ }^{0}$ 11.187, de 19.10.2005 - Regime de retenção recursal agravo de instrumento e agravo retido. Revista Jurídica. Sapucaia do Sul, ano 55, n. 352, fev. 2007.

LUCON, Paulo Henrique dos Santos. O novo regime do agravo (Lei n. 11.185/2005). Revista do Advogado. São Paulo, ano XXVI, n. 85, p. 167, maio 2006.

. Recurso de agravo. In: NERY JR., Nelson; WAMBIER, Tereza Arruda Alvim (Coord.). Aspectos polêmicos e atuais dos recursos cíveis e assuntos afins. São Paulo: RT, 2007. v. 11.

LUZ, Valdemar P. da. Manual dos recursos judiciais. 2. ed. São Paulo: Manole, 2007.

MAGRI, Berenice Soubhie Nogueira. O papel decisivo dos regimentos internos do Supremo Tribunal Federal e do Superior Tribunal de Justiça na admissibilidade dos recursos extraordinário e especial. In: WAMBIER, Teresa Arruda Alvim (Coord.). Aspectos polêmicos e atuais do recurso especial e recurso extraordinário. São Paulo: RT, 1997. p. 65-98.

MALLET, Estêvão. Sentença terminativa e julgamento imediato. In: NERY JR., Nelson; WAMBIER, Teresa Arruda Alvim (Coord.). Aspectos polêmicos e atuais dos recursos cíveis e de outros meios de impugnação a decisões judiciais. São Paulo: RT, 2003. v. 7. 
MANDRIOLI, Crisanto. Corso di diritto processuale civile. 11. ed. Torino: Giappichelli. 1997.

MANCUSO, Rodolfo de Camargo. Acesso à justiça. São Paulo. RT, 2011.

— Recurso extraordinário e recurso especial. São Paulo: RT, 2012.

MARCATO, Ana Cândida Menezes. Princípio do duplo grau de jurisdição e a reforma do Código de Processo Civil. 2006. Dissertação (Mestrado) - USP, São Paulo.

MARCATO, Antonio Carlos. Preclusões: limitação ao contraditório? Revista de Processo, São Paulo: RT, ano V, n. 17, p. 107, jan.-mar. 1980.

MARINONI, Luiz Guilherme; ARENHART, Sérgio Cruz. Processo de conhecimento. 7. ed. São Paulo: RT, 2008.

MARQUES, José Frederico. Instituições de direito processual civil. Campinas: Millennium, 2000. v. 4.

MARTINS FILHO, Ives Gandra. O critério de transcendência no recurso de revista. Disponível em: <www.agu.gov.br/ce/cenovo/revista>. Acesso em: 23 fev. 2014.

MEDINA, José Miguel Garcia. O prequestionamento e os pressupostos dos recursos extraordinário e especial. In: WAMBIER, Teresa Arruda Alvim (Coord.). Aspectos polêmicos e atuais do recurso especial e recurso extraordinário. São Paulo: RT, 1997. p. 250-323.

—. O prequestionamento nos recursos extraordinário e especial. 3. ed. São Paulo: RT, 2002.

—. Recursos “prematuros” e jurisprudência defensiva. Disponível em: $<$ http://www.antonelliadv.com.br/DaVinci/site/antonelli/midia/140211123030arquiv o_6.pdf>. Acesso em: 25 fev. 2014.

—; WAMBIER, Teresa Arruda Alvim. Recursos e ações autônomas de impugnação. 2. ed. São Paulo: RT, 2011. p. 58. (Processo civil moderno, v. 2.)

MEDINA, Paulo Roberto de Gouveia. Duplo grau de jurisdição e efeito suspensivo. In: NERY JR., Nelson; WAMBIER, Tereza Arruda Alvim (Coord.). Aspectos polêmicos e atuais dos recursos cíveis de acordo com a Lei 9.756/98. São Paulo: RT, 1999. 
. O preparo dos recursos em face da instrumentalidade do processo. In: NERY JR., Nelson; WAMBIER, Tereza Arruda Alvim (Coord.). Aspectos polêmicos e atuais dos recursos cíveis e de outras formas de impugnação às decisões judiciais. São Paulo: RT, 2001.

MENDONÇA LIMA, Alcides de. Introdução aos recursos cíveis. 2. ed. São Paulo: RT, 1976.

—_ Recursos cíveis: sistema de normas gerais. São Paulo: Freitas Bastos, 1963.

MILLER, Cristiano Simão. O formalismo processual em sede recursal como obstáculo ao acesso à justiça. Anais do XVIII Congresso Nacional do CONPEDI, realizado em São Paulo - SP em 4 a 7 nov. 2009. Disponível em: $<$ http://www.publicadireito.com.br/conpedi/manaus/arquivos/Anais/sao_paulo/2487. pdf $>$. Acesso em: 16 ago. 2010.

MIRANDA, Gilson Delgado; PIZZOL, Patrícia Miranda. Recursos no processo civil. 5. ed. São Paulo: Atlas, 2008.

NASCIMENTO, Bruno Dantas. Na contramão das reformas processuais: críticas ao novo parágrafo único do art. 527 do CPC, com redação dada pela Lei 11.187/2005. Revista de Processo. São Paulo, ano 30, n. 130, dez. 2005.

—. O recurso extraordinário e a Lei 11.418/2006: notas sobre a dinâmica da repercussão geral. In: MEDINA, José Miguel Garcia; CRUZ, Luana Pedrosa de Figueiredo; CERQUEIRA, Luiz Otávio Sequeira de; GOMES JÚNIOR, Luiz Manoel (Coord.). Os poderes do juiz e o controle das decisões judiciais. Estudos em homenagem à Professora Teresa Arruda Alvim Wambier. São Paulo: RT, 2008.

NERY JR., Nelson. Fundamentos da apelação como requisito de admissibilidade. Revista de Processo. São Paulo, ano V, n. 18, p. 112, 1980.

—. Teoria geral dos recursos. 7. ed. São Paulo: RT, 2014.

— Paulo: RT, 2009.

NOGUEIRA, Gustavo Santana. A repercussão geral do recurso extraordinário e a Emenda Regimental 21/2007 do STF - uma proposta de interpretação da análise deste novo requisito de admissibilidade. In: MEDINA, José Miguel Garcia; CRUZ, Luana Pedrosa de Figueiredo; CERQUEIRA, Luiz Otávio Sequeira de; GOMES JÚNIOR, 
Luiz Manoel (Coord.). Os poderes do juiz e o controle das decisões judiciais. Estudos em homenagem à Professora Teresa Arruda Alvim Wambier. São Paulo: RT, 2008.

OLIVEIRA, Carlos Alberto Alvaro de. O formalismo no processo civil. Proposta de um formalismo-valorativo. 4. ed. São Paulo: Saraiva, 2010.

—. O formalismo valorativo no confronto com o formalismo excessivo. Revista de Processo. São Paulo, p. 19, 2006.

OLIVEIRA, Bruno Silveira de. O formalismo do sistema recursal à luz da instrumentalidade do processo. Revista de Processo. São Paulo, ano 33, n. 160, p. 33-34, jun. 2008.

; COLNALGO, Cláudio de Oliveira Santos. Preparo e deserção (réquiem a algumas inconstitucionalidades). In: OLIVEIRA, Bruno Silveira de; CHEIM JORGE, Flávio; RODRIGUES, Marcelo Abelha, NOLASCO, Rita Dias; MAZZEI, Rodrigo (Coord.). Recursos e a duração razoável do processo. Brasília: Gazeta Jurídica, 2013.

OLIVEIRA, Gleydson Kleber Lopes de. Hipóteses que não sujeitam à conversão do agravo de instrumento em retido. Exegese do art. 527, II, do CPC, à luz da jurisprudência do STJ. In: MEDINA, José Miguel Garcia; CRUZ, Luana Pedrosa de Figueiredo; CERQUEIRA, Luiz Otávio Sequeira de; GOMES JÚNIOR, Luiz Manoel (Coord.). Os poderes do juiz e o controle das decisões judiciais. Estudos em homenagem à Professora Teresa Arruda Alvim Wambier. São Paulo: RT, 2008.

PEREIRA JUNIOR, José Aldizio. Em poucas palavras: dispositivos do Novo CPC contrários à jurisprudência defensiva. Conteúdo Jurídico, Brasília, 14 dez. 2013. Disponível em: <http:/www.conteudojuridico.com.br/?artigos\&ver=2.46268>. Acesso em: 27 fev. 2014.

PERROT, Roger. O processo civil francês na véspera do século XXI. Tradução de José Carlos Barbosa Moreira. Revista de Processo, São Paulo, ano 23, n. 91, p. 204, 1998.

PINTO, Nelson Luiz. Manual dos recursos cíveis. 3. ed. São Paulo: Malheiros, 2004.

- Recurso especial para o Superior Tribunal de Justiça teoria geral e admissibilidade. São Paulo: Malheiros, 1992. 
PIZZORUSSO, Alessandro. Sul principio del doppio grado di giurisdizione. Rivista di Diritto Processuale. Padova, n. 1, v. 33, p. 36, 1978.

PL 8.046/2010 - Projeto do Novo Código de Processo Civil.

POLI, Roberto. Giusto processo e oggetto del giudizio di appello. Rivista di Diritto Processualle. Milano, v. 65 (II Serie), p. 51-52, 2010.

PROVINCIALI, Renzo. Trattato del processo civile. Napoli: Morano, 1962.

PROTO PISANI, Andrea. Diritto processuale civile. 3. ed. Napoli: Jovene, 1999.

PUOLI, José Carlos Baptista. Os poderes do juiz e as reformas do processo civil. São Paulo: Juarez de Oliveira, 2002.

REDENTI, Enrico. Diritto processuale civile. 4. ed. Milano: Giuffrè, 1997. v. 2.

RE, Edward D. Sovraccarico, lentezza e costi del processo in U.S.A. Rivista di Diritto Processual. Padova, anno XXXII, n. 3, p. 311-312, 1986.

RIBEIRO, Antônio de Pádua. Do recurso especial para o Superior Tribunal de Justiça. In: TEIXEIRA, Sálvio de Figueiredo (Coord.). Recursos no Superior Tribunal de Justiça. São Paulo: Saraiva, 1991.

RICCI, Edoardo F. Il doppio grado di giurisdizione nel processo civile. Rivista di Diritto Processuale. Padova, n. 1, v. 33, p. 59-85, 1978.

RIZZI, Sérgio. Recurso adesivo. Revista de Processo. São Paulo, ano VIII, n. 30, 1983.

RODRIGUES, Walter Piva. O princípio da colegialidade das decisões nos tribunais. Revista Dialética de Direito Processual. São Paulo, p. 177, abr. 2003.

RUGGERI, Emanuele. Il principio di consumazione dell'impugnazione: origine ed applicazioni. Rivista di Diritto Processuale. Padova, anno LXIII, Seconda Serie, n. 4, p. 1010, 2008.

SANDULLI, Piero. Il diritto alla tutela giurisdizionale alla luce della dichiarazione universale del diritto dell'uomo del 10 dicembre 1948. Rivista Diritto Processuale. Milano, anno LXIV, Seconda Serie, n. 2, p. 389-390, 2009.

SANSEVERINO, Milton. Fungibilidade dos recursos. Revista de Processo. São Paulo, ano VII, n. 25, p. 182-183, 1982. 
SANTOS, Francisco Cláudio de Almeida. Recurso especial - visão geral. In: TEIXEIRA, Sálvio de Figueiredo (Coord.). Recursos no Superior Tribunal de Justiça. São Paulo: Saraiva, 1991.

SATTA, Salvatore. Commentario al codice di procedura civile. Milano: Villardi, 1966. Diritto processuale civile. Padova: Cedam, 1981.

SCHWIND, Rafael Wallbach. O regime do recurso de agravo com as alterações da Lei 11.187/2005. In: MEDINA, José Miguel Garcia; CRUZ, Luana Pedrosa de Figueiredo; CERQUEIRA, Luiz Otávio Sequeira de; GOMES JÚNIOR, Luiz Manoel (Coord.). Os poderes do juiz e o controle das decisões judiciais. Estudos em homenagem à Professora Teresa Arruda Alvim Wambier. São Paulo: RT, 2008.

SEABRA FAGUNDES, M. Dos recursos ordinários em matéria civil. Rio de Janeiro: Forense, 1946.

SICA, Heitor Vitor Mendonça. Preclusão processual civil. 2. ed. São Paulo: Atlas, 2008. Recorribilidade das interlocutórias e reformas processuais: novos horizontes do agravo retido. In: NERY JR., Nelson; WAMBIER, Teresa Arruda Alvim (Coord.). Aspectos polêmicos e atuais dos recursos cíveis. São Paulo: RT, 2005. v. 8.

SUMMERS, Robert S. O caráter formal do direito. Tradução de Manoel Gustavo Neubarth Trindade. In: RODRIGUEZ, José Rodrigo (Org.). A justificação do formalismo jurídico. São Paulo: Saraiva, 2011.

TALAMINI, Eduardo. Recorribilidade das decisões sobre tutela de urgência. In: NERY JR., Nelson; WAMBIER, Teresa Arruda Alvim (Coord.). Aspectos polêmicos e atuais dos recursos cíveis e de outras formas de impugnação às decisões judiciais. São Paulo: RT, 2001. v. 4.

. Decisões individuais: legitimidade e controle. In: NERY JR., Nelson; WAMBIER, Teresa Arruda Alvim (Coord.). Aspectos polêmicos e atuais dos recursos cíveis. v. 5, 2002.

Decisões individualmente proferidas por integrantes dos tribunais: legitimidade e controle ("agravo interno”). In: WAMBIER, Tereza Alvim; NERY JR., Nelson (Coord.). Aspectos polêmicos e atuais dos recursos. São Paulo: RT, 2005. v. 8. 
TARUFFO, Michele. Precedente e jurisprudência. Revista de Processo. São Paulo, v. 199, p. 139, 2011.

TARZIA, Giuseppe. Crisi e riforma del processo civile. Rivista di Diritto Processuale. Padova, anno XLVI, Seconda serie, n. 3, p. 639, 1991.

—_. Lineamenti del nuovo processo di cognizione. Milano: Giuffrè, 1996.

TEDESCO, Paulo Camargo. O agravo na Lei 11.187/2005 e o princípio da oralidade. In: NERY JR., Nelson; ALVIM WAMBIER, Teresa Arruda (Coord.). Aspectos polêmicos e atuais dos recursos cíveis e assuntos afins. São Paulo: RT, 2006. v. 9.

TEIXEIRA, Sálvio de Figueiredo. O recurso especial e o Superior Tribunal de Justiça. In: TEIXEIRA, Sálvio de Figueiredo. (Coord.). Recursos no Superior Tribunal de Justiça. São Paulo: Saraiva, 1991.

THEODORO JÚNIOR, Humberto. Curso de direito processual civil. 50. ed. Rio de Janeiro: Forense, 2009. v. 1.

- Inovações da Lei 10.352/01. In: NERY JR., Nelson; WAMBIER, Teresa Arruda Alvim (Coord.). Aspectos polêmicos e atuais dos recursos cíveis. São Paulo: RT, v. 6, 2002.

— - O poder de controle do cabimento do recurso extraordinário referente ao requisito da repercussão geral (CF, art. 102, § 3. ${ }^{\circ}$ ). In: MEDINA, José Miguel Garcia; CRUZ, Luana Pedrosa de Figueiredo; CERQUEIRA, Luiz Otávio Sequeira de; GOMES JÚNIOR, Luiz Manoel (Coord.). Os poderes do juiz e o controle das decisões judiciais. Estudos em homenagem à Professora Teresa Arruda Alvim Wambier. São Paulo: RT, 2008.

TROCKER, Nicolò. Dal giusto processo all'effettività dei rimedi: l'<azione> nell'elaborazione della Corte europea dei diritti dell'uomo. Parte seconda. Rivista Trimestrale di Diritto e Procedura Civile. Milano, anno LXI, n. 2, p. 439, 2007.

VELLANI, Mario. Appello (Diritto processuale civile). Enciclopedia del Diritto. Varese: Giuffrè, 1958. II.

VENTURI, Elton. Anotações sobre a repercussão geral como pressuposto de admissibilidade do recurso extraordinário. In: MEDINA, José Miguel Garcia; CRUZ, Luana Pedrosa de Figueiredo; CERQUEIRA, Luiz Otávio Sequeira de; GOMES JÚNIOR, Luiz Manoel (Coord.). Os poderes do juiz e o controle das decisões 
judiciais. Estudos em homenagem à Professora Teresa Arruda Alvim Wambier. São Paulo: RT, 2008.

VERDI, Giovanni. Il processo sotto l'incubo della ragionevole durata. Rivista di Diritto Processuale. Padova, anno LXVI, Seconda serie, n. 3, p. 508, 2011.

VÉSCOVI, Enrique. Teoría general del proceso. 2. ed. Santa Fe de Bogotá: Temis, 1999. VIGORITI, Vincenzo. Costo e durata del processo civile: spunti per uma riflessione. Rivista di Diritto Civile. Padova, anno XXXII, n. 3, p. 319, 1986.

—. Notas sobre o custo e a duração do processo civil na Italia. Revista de Processo. São Paulo, ano 11, n. 43, p. 143, jul.-set. 1986.

WAMBIER, Luiz Rodrigues; ALMEIDA, Flávio Renato Correia de; TALAMINI, Eduardo. Curso avançado de processo civil. 6. ed. São Paulo: RT, 2003. v. 1.

WAMBIER, Teresa Arruda Alvim. O novo regime do agravo. 2. ed. São Paulo: RT, 1996.

- O princípio da fungibilidade sob a ótica da função instrumental do processo. In: —; NERY JR., Nelson (Coord.). Aspectos polêmicos e atuais dos recursos cíveis. São Paulo: RT, 2005. v. 8.

—. Os agravos no CPC brasileiro. 4. ed. São Paulo: RT, 2006.

—. Recurso especial, recurso extraordinário e ação rescisória. 2. ed. São Paulo: RT, 2008.

—. Restrições indevidas ao direito de recorrer. Revista de Processo. São Paulo, n. 130, 2005.

WATANABE, Kazuo. Política pública do poder judiciário nacional para tratamento adequado dos conflitos de interesses. São Paulo: RT, Revista de Processo. n. 195, mai, 2011.

YOSHIKAWA, Eduardo Henrique de Oliveira. Recursos no direito processual civil norteamericano. Revista de Processo. São Paulo, ano 38, v. 221, 2013.

—. Recursos no processo inglês. Revista de Processo. São Paulo, ano 38, v. 220, 2013. 
ZANFERDINI, Flávia de Almeida Montingelli. Prazo razoável - direito à prestação jurisdicional sem dilações indevidas. Revista Síntese de Direito Civil e Processo Civil. Porto Alegre, ano IV, v. 22, p. 15, mar.-abr. 2003. 